\title{
4. SITE 368: CAPE VERDE RISE
}

\author{
The Shipboard Scientific Party ${ }^{1.2}$
}

\section{SITE DATA}

Date Occupied: 13 March 1975 (0651)

Date Departed: 20 March 1975 (0928)

Time on Site: 7 days, 2 hours, 37 minutes

Position: $17^{\circ} 30.4^{\prime} \mathrm{N}, 21^{\circ} 21.2^{\prime} \mathrm{W}$

Water Depth: 3366 corrected meters (echo sounding)

Bottom Felt With Drill Pipe at: 3377 meters below rig floor

Penetration: 984.5 meters

Number of Holes: 1

Number of Cores: 63

Total Length of Cored Section: 582.5 meters

Total Core Recovered: 327.7 meters

\section{BACKGROUND AND OBJECTIVES}

The Cape Verde Rise is one of the most prominent features of the West African continental rise. It extends westward from the African continental slope off Mauritania and Senegal where it spans about $5^{\circ}$ in latitude. It extends west of the Cape Verde Islands, although in deeper waters, where it nearly reaches the flank of the Mid-Atlantic Ridge. It separates the eastern North Atlantic into the Cape Verde Basin to the south and the Canary Basin to the north. The larger part of the rise is between the Cape Verde Islands and the African continent, mainly northeast of the islands. There, the rise takes the shape of a large smooth domeshaped elevation reaching depths as shallow as about 2950 meters (Figure 1). The upper part of this dome is

'Yves Lancelot, Lamont-Doherty Geological Observatory, Palisades, New York (Co-Chief Scientist); Eugen Seibold, Geologisch-Palaontologisches, Institüt and Museum der Universität Kiel, Kiel, Germany (Co-Chief Scientist); Pavel Čepek, Bundesanstalt für Bodenforschung, Hannover, Federal Republic of Germany; Walter E. Dean, Syracuse University, Department of Geology, Syracuse, New York; Vladislav Eremeev, Institute of Geological Sciences of the Academy of Sciences, Laboratory of Lithology Formation, Moscow, USSR; James Gardner, Deep Sea Drilling Project, Scripps Institution of Oceanography, La Jolla, California; Lubomir F. Jansa, Atlantic Geoscience Centre, Geological Survey of Canada, Bedford Institute of Oceanography, Dartmouth, Nova Scotia; David Johnson, Woods Hole Oceanographic Institution, Woods Hole, Massachusetts; Valery Krasheninnikov, Geological Institute of the Academy of Sciences of the USSR, Moscow, USSR; Uwe Pflaumann, GeologischPalaontologisches, Institüt und Museum der Universität Kiel, Kiel, Germany; J. Graham Rankin, Northeast Louisiana University, Department of Chemistry, Monroe, Louisiana; Peter Trabant, Texas A\&M University, Department of Oceanography, College Station, Texas.

${ }^{2}$ David Bukry, U.S. Geological Survey, La Jolla, California (Tertiary nannofossils).

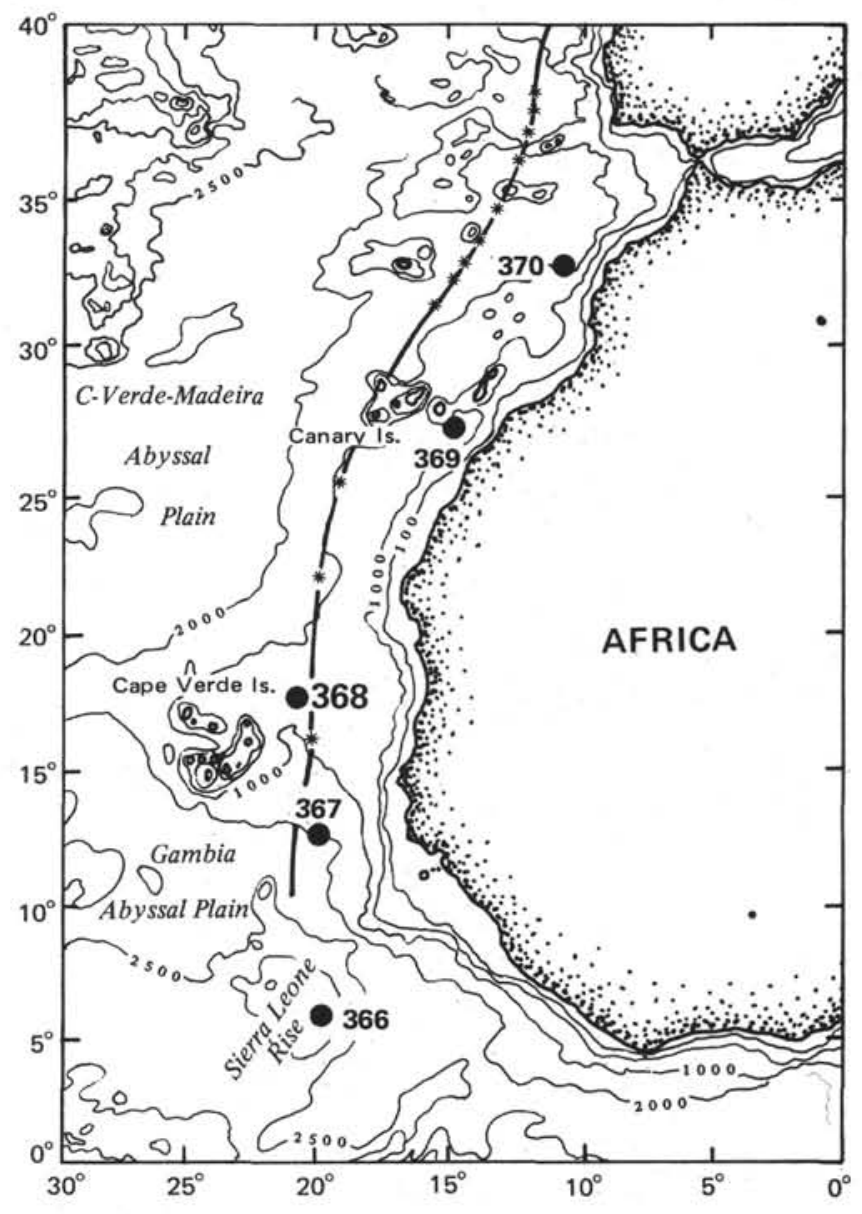

actually separated from the African continental rise by a broad sill where water depths are not deeper than about 3100 meters.

Seismic reflection profiles recorded on the rise (Figure 2) show that the broad elevation is underlain by parallel reflectors. The lowermost reflector $\left(D_{1}\right)$ can be correlated with reflector $\beta$ in the basins. It appears roughly parallel to the upper reflectors and parallel to the sea floor. The nature of the pre-Pleistocene sedimentary section and the origin of the broad rise were totally unknown prior to this cruise. The basement cannot be seen on the Meteor profile and data available prior to the cruise did not indicate the presence of a basement high beneath that part of the rise. However, multichannel seismic profiles by Shell International Petroleum, shown to us just after the cruise, show that the basement is regionally at about 6 to $7 \mathrm{sec}$ below sea surface, that is about $1 \mathrm{sec}$ below reflector $D_{1}$. This suggests a purely sedimentary origin for the feature. The series of visible parallel reflectors, therefore, was interpreted as the result of a relatively old accumulation 


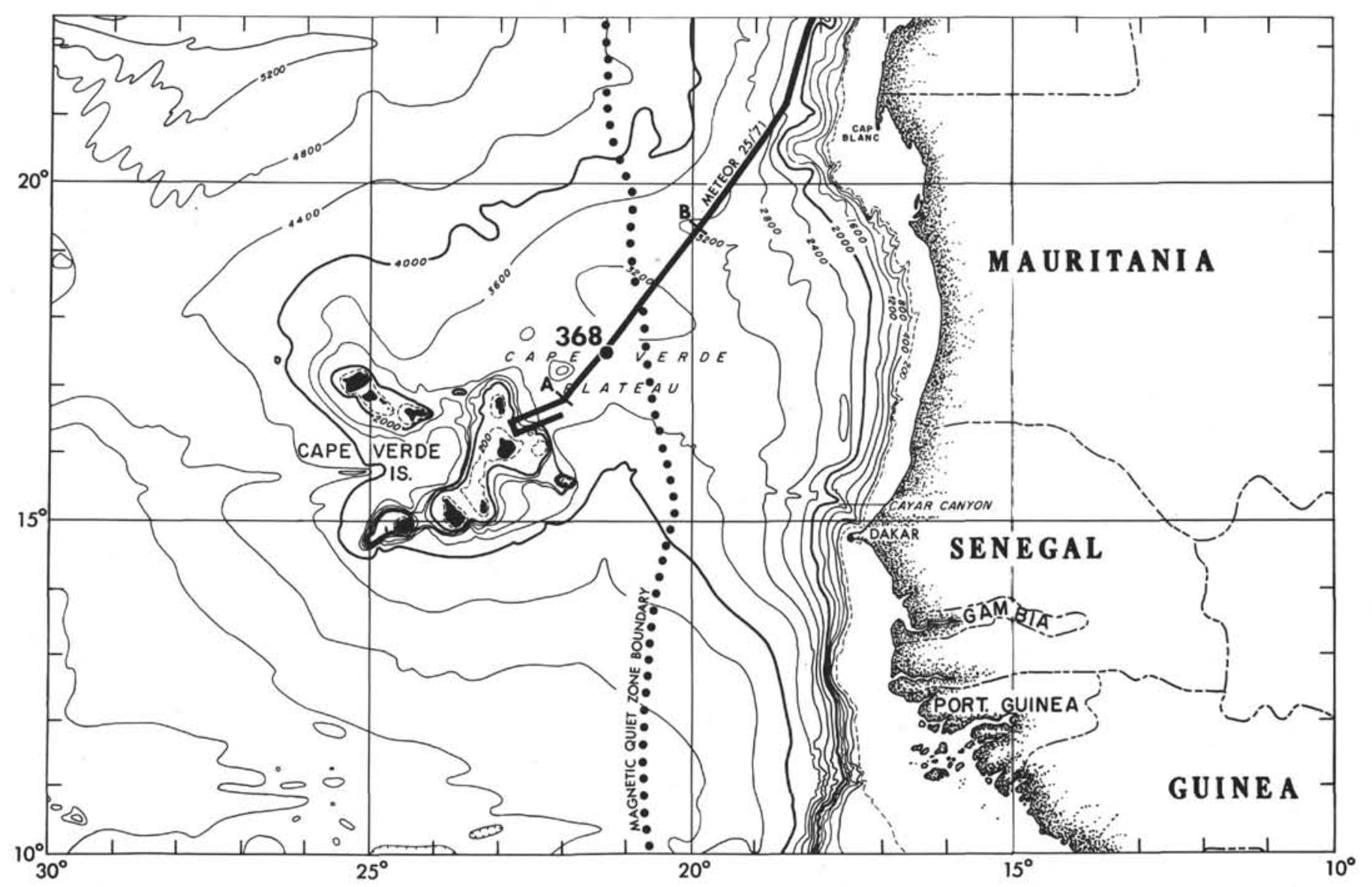

Figure 1. Location of Site 368. Bathymetry from Jacobi and Hayes (in preparation); magnetic Quiet Zone boundary from Hayes and Rabinowitz (1975).

of sediment. If, as indicated by the Shell profile, a local basement high is present underneath the dome, then the series of parallel reflectors could also be explained by a young uplift. Pleistocene and Holocene sediments recovered from piston cores are mainly pelagic with some terrigenous eolian components. The accumulation rates for the Holocene and the interglacial periods are about $20 \mathrm{~mm} / 1000 \mathrm{yr}$ and they reach 30 to 50 $\mathrm{mm} / 1000 \mathrm{yr}$ during the glacial intervals (Pflaumann, 1975; Gardner, 1975). The parallel bedding observed on the seismic reflection profiles suggests an accumulation of pelagic sediments during most or all of the Tertiary and Late Cretaceous. The relatively shallow water depth suggests that the area has been above the CCD during most of these times, if young and substantial uplift is excluded. The section is needed to compare with that of Sierra Leone Rise (Site 366) where the water depth is only 517 meters shallower than at this site, although at Site 366 the productivity was probably much higher during most of the Tertiary, due to the proximity of the equator. Terrigenous input on the Cape Verde Rise, caused by abundant detrital discharge from African rivers, might be more abundant. Such terrigenous contributions could be responsible for the sharp, closely spaced, parallel reflectors observed on the seismic profiles. It is possible to speculate that the terrigenous contribution was primarily delivered to the ocean through an active river system during the Paleogene. Then progressively, while more semi-arid to arid conditions became prevalent due to the northward motion of Africa with respect to the equator, wind-transported material might be more abundant. Some volcanogenic contribution was also expected during the Miocene, at the time of maximum eruptive volcanic activity on the Cape Verde Islands. The sediment accumulation was also tentatively thought to have been at least in part, controlled by current circulation at least after the Eocene, and more probably during Miocene, when circulation of Antarctic Bottom Water in the Atlantic was initiated. One effect of this bottom circulation could have been the relative reduction of sediment accumulation on the sill observed between the dome-shaped area and the continental rise.

Site 368 is located on the southwestern, gently sloping, flank of the dome (Figure 1) in 3367 meters of water. The site could not be located on top of the dome for safety reasons. The seismic profile recorded while approaching the site (Figure 3 ) is similar to the Meteor profile from which the site was selected (Figure 2). They both show the presence of an uppermost transparent layer (from the sea floor to $0.26 \mathrm{sec}$ ) over a finely stratified series of reflectors (from 0.26 to $0.58 \mathrm{sec}$ ). Regional correlations show that Horizon A may be present, but barely visible, within the lower half of the stratified zone. Below that level the section appears 


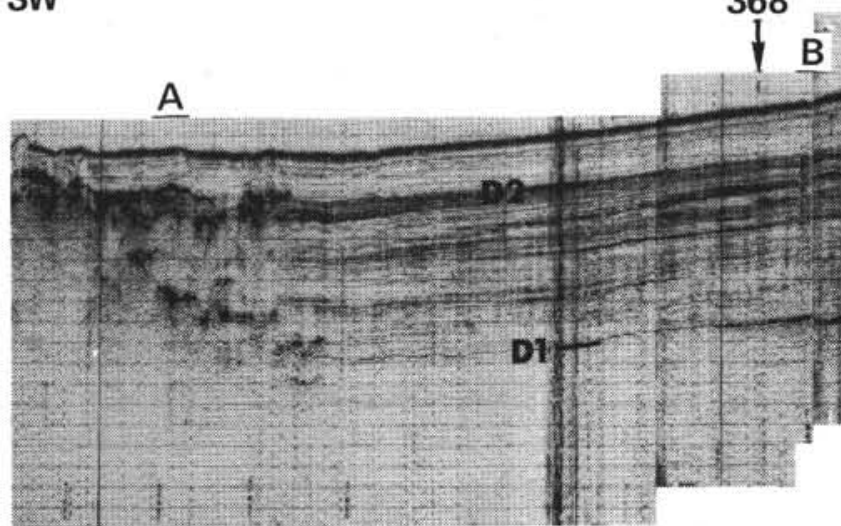

\section{B}

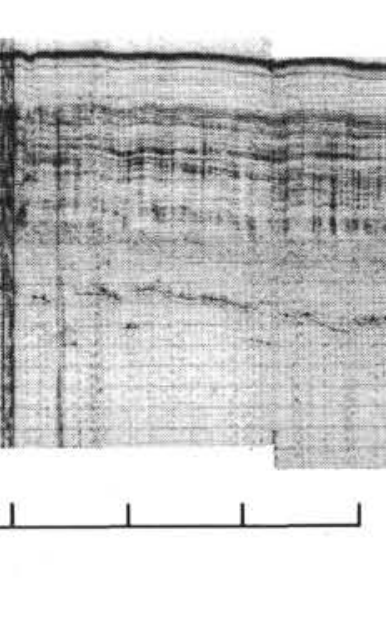

SW

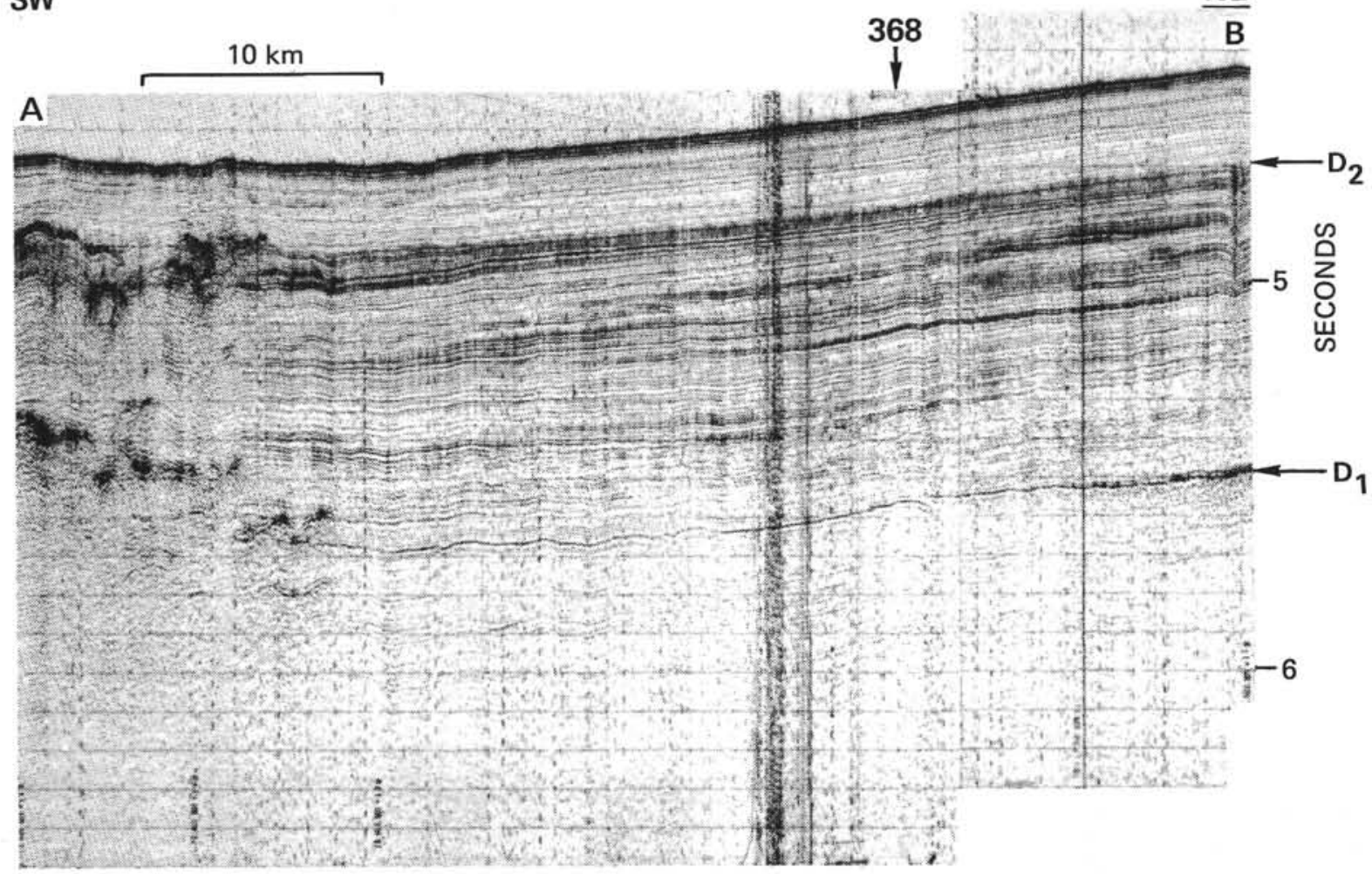

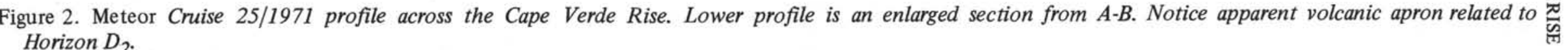




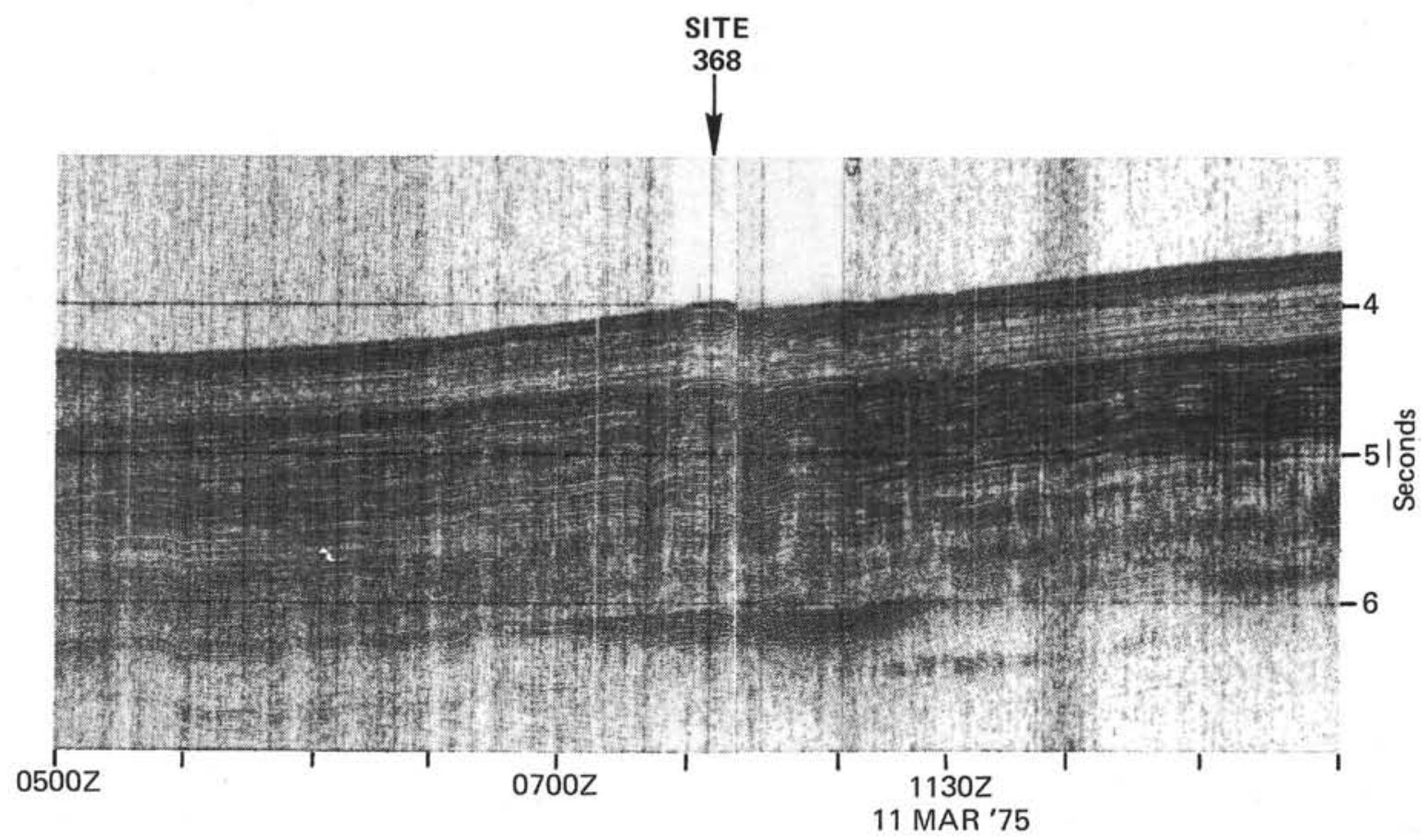

Figure 3. Glomar Challenger seismic-reflection profile recorded while approaching and leaving Site 368. (See underway geophysics chapter paper annotations.)

moderately stratified (from 0.50 to $0.77 \mathrm{sec}$ ) to more or less transparent $(0.77$ to $1.05 \mathrm{sec})$. At $1.05 \mathrm{sec}$, a particularly sharp and relatively thin reflector is observed (reflector $D_{1}$ ). It correlates with Horizon $\beta$ in the basins, but is particularly sharp under Cape Verde Rise, and in general under the continental rise. Some weak reflectors parallel to that horizon are still visible below that reflector and no indication can be observed.

The main objectives for this site were to determine the nature and age of the different reflectors and to compare the nature of the sediments with those sampled at a comparable depth on Sierra Leone Rise (Site 366) and in deeper water, at Cape Verde (Site 367) and southeastern Canary basins (Site 140).

If the age of reflector $D_{1}$ is Early Cretaceous, as suggested by correlations with Site 367 , then the total thickness of overlying sediments on Cape Verde Rise appears intermediate between the thicknesses observed on Sierra Leone Rise and in the basin, respectively. Therefore, there appeared to be a good opportunity at this site to obtain a better stratigraphic control in the Upper Cretaceous and Tertiary sediments than in the basin where dissolution should have been more active. The combination of Sites 367,368 , and 140 could then provide a very complete record of the sedimentary evolution of that part of the North Atlantic and an explanation of the origin of the Cape Verde Rise.

Ideally, the entire section should be sampled almost continuously. Because of time constraints, continuous coring was planned to be used selectively to concentrate the sampling in time-stratigraphic intervals of special interest. The upper section was to be spot cored until upper Miocene sediments were encountered. The transition between late and middle Miocene was to receive special attention as it was found during Leg 14 to correspond with a major change in sedimentation. Extensive dissolution during the middle Miocene and early Tertiary is probably responsible for the deposition of carbonate-poor sediments in the Canary Basin (Site 140) whereas late Miocene sediments show an abrupt increase in carbonate contents.

Continuous coring or very closely spaced coring was planned below the middle Miocene, through the Oligocene and down to the Cretaceous/Tertiary boundary. This offered an opportunity to investigate the presence or absence of hiatuses in the Oligocene and near the Cretaceous/Tertiary boundary. Coring would be closely spaced below that level, down to the level of reflector $D_{1}$.

\section{OPERATIONS}

The area of Site 368 was approached on a $061^{\circ}$ course and, as for the previous sites, it was decided to intercept the reference Meteor profile about $16 \mathrm{~km}$ southwest of the proposed site (see Figure 4). The interception point was reached at 0530 on 13 March 1975, and the ship turned to a heading of $030^{\circ}$ to follow the Meteor track. The profiler record (Figure 3) looked identical to that of the Meteor and the speed was reduced to about 5 knots at 0625 when approaching the site. A $16-\mathrm{kHz}$ ORE single-life beacon was dropped underway at 0635 ; the gear was immediately retrieved and the ship headed back toward the beacon. The "lock on" was effective at 0651 at $17^{\circ} 30.4^{\prime} \mathrm{N}$ and $21^{\circ} 21.2^{\prime} \mathrm{W}$. The PDR water depth was recorded at 3366 corrected meters (from sea level). Drill pipe was lowered and the bottom was felt by the driller at $1349 \mathrm{hr}$ when the total length of drill string reached 3367 meters from sea level ( $3377 \mathrm{~m}$ from the rig floor). That depth was accepted as the official water depth for Site 368.

The coring operation started immediately and two successive cores were punched from 0 to 18.5 meters. Then intermittent coring was performed without circulation down to 161 meters where continuous 


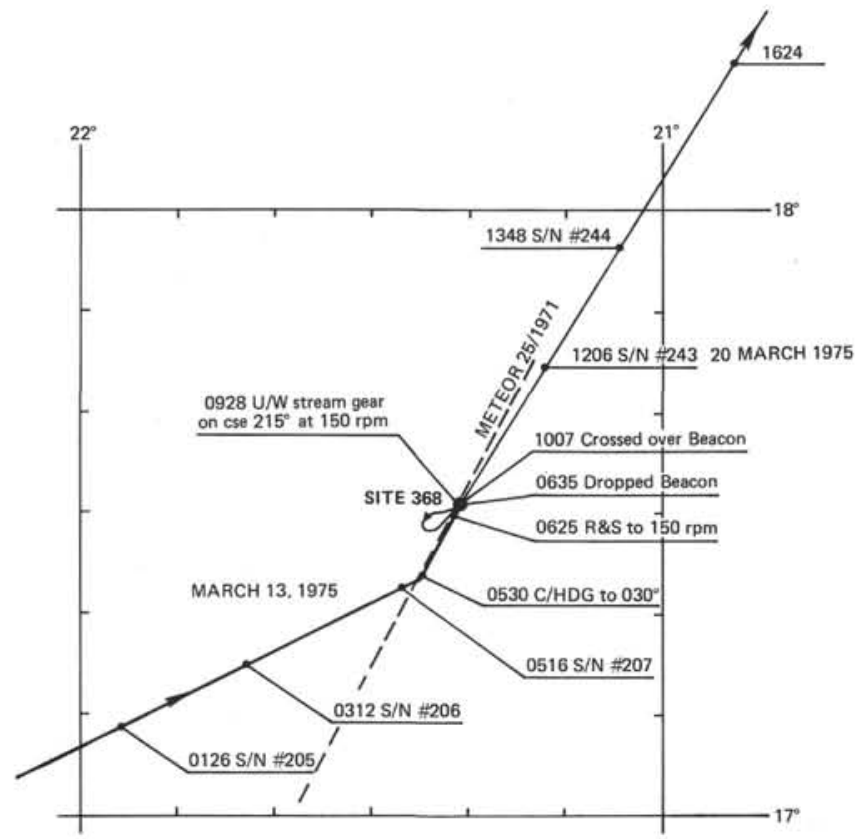

Figure 4. Track lines of Glomar Challenger (solid line) while approaching and leaving Site 368. Meteor profile 25/1971 is in dashed line.

cores and then continuous pumping below that level. Coring was almost continuous down to 731 meters, intermittent down to 921 meters, and continuous again down to a total depth of 984.5 meters.

Coring operations were often very slow in plastic clays and after experiencing zero recovery in two successive cores (Cores 48 and 49) it became apparent that the bit was plugged with clay. A chisel center bit was dropped and run back and forth through the bit several times until the bit was cleared. To avoid plugging of the bit while drilling between cores the center bit was used in the plastic clayey formation. When relatively hard claystone or shale were encountered, intervals between cores were drilled with the presumably full core barrel in place. This technique proved the most efficient to achieve relatively fast penetration without continuous coring. After crossing a diabase sill in Cores 61 and 62 (see Table 1), taking 200 and 150 minutes to cut, respectively, sediments were encountered again. The hole was abandoned because of the presence of gas in the sediment and the deepest objective for this site was to core the reflector that was found to correspond with the sill. A total of 63 cores was cut representing a total length of 582.5 meters of which 327.7 meters $(56 \%)$ were recovered.

The post-site survey consisted simply of a run over the beacon and course was set toward Site 369 (see Figure 4 and profile on Figure 3 ). No sonobuoy record was attempted on this site.

\section{LITHOLOGY}

We subdivided the section into three units on the basis of color and composition (Table 2). A lithologic description is presented in Table 2.
Unit 1

\section{Subunit 1a-Foram-bearing Nanno Marl and Ooze (Cores 1 through 5)}

Subunit la consists of interbedded marl and ooze with abundant nannofossils, common foraminifers, and rare radiolarians. Diatoms are rare to common, and sponge spicules are rare in the upper part of the unit, but are generally absent below Core $3(57 \mathrm{~m})$. Detrital materials, such as clay, silt-size quartz, heavy minerals, and feldspars, are most abundant near the top of the subunit and decrease with depth. This results in a general lithologic change from marl to ooze in the upper part of the subunit, to only ooze in the lower part. Eolian input in the upper part of the subunit is indicated by rare opal phytoliths and fresh-water diatoms. Fluctuations in $\mathrm{CaCO}_{3}$ and clay are reflected in the colors of the sediments, which become generally lighter with depth. Near the top of the subunit, dominant colors are yellowish browns, grays, and olives with numerous varicolored interbeds. With depth, the units become mainly light gray (N7 and N8) with light greenish gray $(5 G Y 8 / 1)$ interbeds. Welldeveloped gray ooze-green chalk cycles (averaging 3 to 4 cycles per section) are apparent in Core 5 , again reflecting fluctuations in $\mathrm{CaCO}_{3}$ and/or clay contents. $\mathrm{CaCO}$ values range from $50 \%$ to $86 \%$. The carbonate is mainly in the form of calcareous fossils, although rare dolomite (?) rhombs were observed in smear slides.

\section{Subunit 1b-Light Gray Nannofossil Ooze Grading Downward into Greenish Gray Marl and Clay (Cores 6 through 16)}

Subunit $1 \mathrm{~b}$ consists of interbedded nannofossil ooze, marl, and clay. At the top of the subunit (Cores 6 through 8), nannofossils are usually dominant, then decrease to rare and common in Cores 9 through 16, and become generally absent below Core 16 . Foraminifers are rare throughout subunit $1 \mathrm{~b}$, and radiolarians are either rare or absent at the top of the subunit, but become common in radiolarian-bearing clay in Cores 13 and 15. An increase with depth of detrital influx is shown by an increase in clay, and the sudden appearance in Core 8, Section 5 (185 m subbottom) of coarser clastics, especially silt-size quartz, feldspar, and heavy minerals. Silt-size quartz was observed below Core 8 as a rare to common component in most smear slides. Smear slides show an increase in pyrite beginning with Core $10(200 \mathrm{~m})$. Volcanic-ash layers occur in Core 13, Section 4, 126 to $130 \mathrm{~cm}$; Core 14, Section 2, 35 to $50 \mathrm{~cm}$; and Core 14, Section 3, 60 to $62 \mathrm{~cm}$. Dominant colors range from light gray (N8) ooze at the top of the subunit to greenish gray and bluish green marl. Cyclic light dark alterations of ooze or marl, and marl or clay occur at several places within the subunit. $\mathrm{CaCO}_{3}$ values range from highs of greater than $80 \%$ in ooze at the top of the subunit, to $0 \%$ in clay at the bottom of the subunit. Most of the carbonate is from calcareous fossils, but rare dolomite (?) rhombs occur. 
TABLE 1

Coring Summary for Site 368

\begin{tabular}{|c|c|c|c|c|c|c|c|}
\hline Core & $\begin{array}{c}\text { Date } \\
\text { (March 1975) }\end{array}$ & Time & $\begin{array}{l}\text { Depth From Drill } \\
\text { Floor }(\mathrm{m})\end{array}$ & $\begin{array}{c}\text { Depth Below Sea } \\
\text { Floor }(\mathrm{m})\end{array}$ & $\begin{array}{l}\text { Cored } \\
(\mathrm{m})\end{array}$ & $\begin{array}{l}\text { Length } \\
\text { Recovered } \\
\text { (m) }\end{array}$ & $\begin{array}{c}\text { Recovered } \\
(\%)\end{array}$ \\
\hline 1 & 13 & 1439 & $3377.0-3386.0$ & $0.0-9.0$ & 9.0 & 8.8 & 98 \\
\hline 2 & 13 & 1559 & $3386.0-3395.5$ & $9.0-18.5$ & 9.5 & 3.5 & 37 \\
\hline 3 & 13 & 1719 & $3424.0-3433.5$ & $47.0-56.5$ & 9.5 & 9.5 & 100 \\
\hline 4 & 13 & 1856 & $3462.0-3471.5$ & $85.0-94.5$ & 9.5 & $9.5+$ & $100+$ \\
\hline 5 & 13 & 2030 & $3500.0-3509.5$ & $123.0-132.5$ & 9.5 & $9.5+$ & $100+$ \\
\hline 6 & 13 & 2139 & $3538.0-3547.5$ & $161.0-170.5$ & 9.5 & 7.7 & 81 \\
\hline 7 & 13 & 2253 & $3547.5-3557.0$ & $170.5-180.0$ & 9.5 & 9.5 & 100 \\
\hline 8 & 14 & 0007 & $3557.0-3566.5$ & $180.0-189.5$ & 9.5 & 7.6 & 80 \\
\hline 9 & 14 & 0111 & $3566.5-3576.0$ & $189.5-199.0$ & 9.5 & 6.5 & 68 \\
\hline 10 & 14 & 0347 & $3576.0-3585.5$ & $199.0-208.5$ & 9.5 & 3.2 & 34 \\
\hline 11 & 14 & 0500 & $3585.5-3595.0$ & $208.5-218.0$ & 9.5 & 4.1 & 43 \\
\hline 12 & 14 & 0603 & $3595.0-3604.5$ & $218.0-227.5$ & 9.5 & 0.3 & 3 \\
\hline 13 & 14 & 0715 & $3604.5-3614.0$ & $227.5-237.0$ & 9.5 & 5.5 & 58 \\
\hline 14 & 14 & 0831 & $3614.0-3623.5$ & $237.0-246.5$ & 9.5 & 3.5 & 37 \\
\hline 15 & 14 & 0948 & $3623.5-3633.0$ & $246.5-256.0$ & 9.5 & 4.8 & 51 \\
\hline 16 & 14 & 1107 & $3633.0-3642.5$ & $256.0-265.5$ & 9.5 & 5.3 & 56 \\
\hline 17 & 14 & 1237 & $3642.5-3652.0$ & $265.5-275.0$ & 9.5 & 7.9 & 83 \\
\hline 18 & 14 & 1438 & $3652.0-3661.5$ & $275.0-284.5$ & 9.5 & $9.5+$ & $100+$ \\
\hline 19 & 14 & 1656 & $3661.5-3671.0$ & $284.5-294.0$ & 9.5 & 3.7 & 39 \\
\hline 20 & 14 & 2012 & $3671.0-3676.0$ & $294.0-299.0$ & 5.0 & 0.6 & 12 \\
\hline 21 & 14 & 2155 & $3690.0-3699.5$ & $313.0-322.5$ & 9.5 & 2.5 & 26 \\
\hline 22 & 15 & 0022 & $3699.5-3709.0$ & $322.5-332.0$ & 9.5 & $9.5+$ & $100+$ \\
\hline 23 & 15 & 0141 & $3728.0-3737.5$ & $351.0-360.5$ & 9.5 & 1.9 & 20 \\
\hline 24 & 15 & 0320 & $3737.5-3747.0$ & $360.5-370.0$ & 9.5 & 0.8 & 8 \\
\hline 25 & 15 & 0525 & $3747.0-3752.5$ & $370.0-375.5$ & 5.5 & 3.2 & 58 \\
\hline 26 & 15 & 0745 & $3752.5-3762.0$ & $375.5-385.0$ & 9.5 & 2.5 & 26 \\
\hline 27 & 15 & 0925 & $3762.0-3771.5$ & $385.0-394.5$ & 9.5 & 4.5 & 47 \\
\hline 28 & 15 & 1105 & $3771.5-3781.0$ & $394.5-404.0$ & 9.5 & 1.5 & 16 \\
\hline 29 & 15 & 1345 & $3785.0-3794.5$ & $408.0-417.5$ & 9.5 & 1.1 & 12 \\
\hline 30 & 15 & 1511 & $3794.5-3804.0$ & $417.5-427.0$ & 9.5 & 2.8 & 30 \\
\hline 31 & 15 & 1713 & $3804.0-3813.5$ & $427.0-436.5$ & 9.5 & 5.7 & 60 \\
\hline 32 & 15 & 1920 & $3813.5-3823.0$ & $436.5-446.0$ & 9.5 & 6.2 & 65 \\
\hline 33 & 15 & 2225 & $3823.0-3832.5$ & $446.0-455.5$ & 9.5 & 2.1 & 22 \\
\hline 34 & 15 & 0157 & $3842.0-3851.5$ & $465.0-474.5$ & 9.5 & 4.5 & 47 \\
\hline 35 & 16 & 0646 & $3861.0-3870.5$ & $484.0-493.5$ & 9.5 & 2.4 & 25 \\
\hline 36 & 16 & 1042 & $3889.5-3899.0$ & $512.5-522.0$ & 9.5 & 3.8 & 40 \\
\hline 37 & 16 & 1453 & $3908.5-3918.0$ & $531.5-541.0$ & 9.5 & 7.1 & 75 \\
\hline 38 & 16 & 1730 & $3937.0-3946.5$ & $560.0-569.5$ & 9.5 & 3.6 & 38 \\
\hline 39 & 16 & 1957 & $3946.5-3956.0$ & $569.5-579.0$ & 9.5 & 8.2 & 86 \\
\hline 40 & 16 & 2156 & $3956.0-3965.5$ & $579.0-588.5$ & 9.5 & 5.3 & 56 \\
\hline 41 & 17 & 0003 & $3965.5-3975.0$ & $588.5-598.0$ & 9.5 & 5.8 & 61 \\
\hline 42 & 17 & 0155 & $3975.0-3984.5$ & $598.0-607.5$ & 9.5 & 3.8 & 40 \\
\hline 43 & 17 & 0420 & $3984.5-3994.0$ & $607.5-617.0$ & 9.5 & 5.4 & 57 \\
\hline 44 & 17 & 0704 & $3994.0-4003.5$ & $617.0-626.5$ & 9.5 & 8.2 & 84 \\
\hline 45 & 17 & 0952 & $4003.5-4013.0$ & $626.5-636.0$ & 9.5 & 7.9 & 83 \\
\hline 46 & 17 & 1130 & $4013.0-4022.5$ & $636.0-645.5$ & 9.5 & $9.5+$ & $100+$ \\
\hline 47 & 17 & 1352 & $4022.5-4032.0$ & $645.5-655.0$ & 9.5 & $9.5+$ & $100+$ \\
\hline 48 & 17 & 1617 & $4041.5-4051.0$ & $664.5-674.0$ & 9.5 & 0.0 & 0 \\
\hline 49 & 17 & 1743 & $4070.0-4079.5$ & $693.0-702.5$ & 9.5 & 0.0 & 0 \\
\hline 50 & 17 & 2110 & $4079.5-4089.0$ & $702.5-712.0$ & 9.5 & 3.3 & 35 \\
\hline 51 & 17 & 2253 & $4089.0-4098.5$ & $712.0-721.5$ & 9.5 & 4.4 & 46 \\
\hline 52 & 18 & 0035 & $4098.5-4108.0$ & $721.5-731.0$ & 9.5 & 6.5 & 68 \\
\hline 53 & 18 & 0508 & $4127.0-4136.5$ & $750.0-759.5$ & 9.5 & 5.2 & 55 \\
\hline 54 & 18 & 1105 & $4174.5-4184.0$ & $797.5-807.0$ & 9.5 & 6.2 & 65 \\
\hline 55 & 18 & 1805 & $4214.5-4222.0$ & $837.5-845.0$ & 7.5 & 4.0 & 53 \\
\hline 56 & 18 & 2330 & $4222.0-4231.5$ & $845.0-854.5$ & 9.5 & 4.3 & 45 \\
\hline 57 & 19 & 0230 & $4269.5-4279.0$ & $892.5-902.0$ & 9.5 & 6.0 & 63 \\
\hline 58 & 19 & 0509 & $4298.0-4307.5$ & $921.0-930.5$ & 9.5 & 7.8 & 82 \\
\hline 59 & 19 & 0703 & $4315.5-4325.0$ & $938.5-948.0$ & 9.5 & 4.1 & 43 \\
\hline 60 & 19 & 1044 & $4326.5-4336.0$ & $949.5-959.0$ & 9.5 & 8.3 & 87 \\
\hline 61 & 19 & 1505 & $4338.0-4345.5$ & $961.0-968.5$ & 7.5 & 7.0 & 93 \\
\hline 62 & 19 & 1842 & $4345.5-4352.0$ & $968.5-975.0$ & 6.5 & 5.0 & 77 \\
\hline 63 & 19 & 2124 & $4352.0-4361.5$ & $975.0-984.5$ & 9.5 & 5.8 & 61 \\
\hline Total & & & & & 582.5 & 327.7 & 56 \\
\hline
\end{tabular}


TABLE 2

Lithostratigraphy at Site 368

\begin{tabular}{|c|c|c|c|}
\hline Unit & Lithology & Cores & Age \\
\hline 1a & $\begin{array}{l}\text { Foram-bearing nanno marl } \\
\text { and ooze }\end{array}$ & $\begin{array}{l}1 \text { through } 5 \\
(0 \text { to } 132.5 \mathrm{~m})\end{array}$ & $\begin{array}{l}\text { Holocene to early } \\
\text { Pliocene }\end{array}$ \\
\hline Ib & $\begin{array}{l}\text { Nanno ooze and marl; } \\
\text { pelagic clay, } 3 \text { volcanic } \\
\text { ash beds }\end{array}$ & $\begin{array}{c}6 \text { through } 16 \\
(161 \text { to } 265.5 \mathrm{~m})\end{array}$ & $\begin{array}{l}\text { Late Miocene to early } \\
\text { Miocene }\end{array}$ \\
\hline $2 a$ & $\begin{array}{l}\text { Cyclic interbeds } \\
\text { of green silty clay and } \\
\text { claystone }\end{array}$ & $\begin{array}{l}17 \text { through } 47 \\
(265.5 \text { to } 655 \mathrm{~m})\end{array}$ & $\begin{array}{l}\text { Early Miocene to early } \\
\text { Eocene? - Early } \\
\text { Cretaceous? }\end{array}$ \\
\hline $2 b$ & $\begin{array}{l}\text { Interbedded green and red } \\
\text { shale }\end{array}$ & $\begin{array}{l}50 \text { through } 52 \\
(702.5 \text { to } 731 \mathrm{~m})\end{array}$ & $\begin{array}{l}\text { Paleocene? - Late } \\
\text { Cretaceous? }\end{array}$ \\
\hline $2 \mathrm{c}$ & $\begin{array}{l}\text { Cyclic interbeds of green } \\
\text { and olive silty claystone; } \\
\text { essentially the same as sub unit } \\
\text { 2a }\end{array}$ & $\begin{array}{r}53 \text { through } 59 \\
(750 \text { to } 950 \mathrm{~m})\end{array}$ & Late Cretaceous \\
\hline 3 & Black shale; diabase sills & $\begin{array}{l}60 \text { through } 63 \\
(950 \text { to } 984.5 \mathrm{~m})\end{array}$ & $\begin{array}{l}\text { Late Cretaceous to } \\
\text { Turonian-Albian }\end{array}$ \\
\hline
\end{tabular}

Unit 2

\section{Subunit 2a-Cyclicly Bedded Green Silty Clays and Claystone (Cores 17 through 47)}

Subunit 2a consists of a relatively thick $(190 \mathrm{~m})$ monotonous sequence of cyclic dark and light green clay and claystone, with an average of about 12 cycles per 1.5 meters. The grayish blue-green ( $5 \mathrm{BG} 5 / 2)$ clay in Cores 17 through 20 is very stiff, but not quite indurated into a claystone. However, claystone occurs by Core 21. Cyclic interbeds of claystone in Core 22 are particularly well developed into fairly simple couplets-light beds of bluish or greenish gray $(5 \mathrm{G} 6 / 1)$, and darker beds of dark greenish gray (5GY4/1). The lower contact of the darker bed is usually sharp but the upper contact is gradational into the overlying lighter bed. Bioturbation is common throughout all of Unit 2. Porcellanite layers and nodules first appear in Core 23 $(350 \mathrm{~m})$ and continue through Core $44(626 \mathrm{~m})$. Chert is not very abundant, and is found mainly in small nodules. Porcellanite normally occurs within the dark member of the dark-light turbidite layers characteristic of Subunit 2a. In Core 23, Section 2, porcellanite occurs in distinct dark greenish gray layers with lighter colored silicified zones on either side. In Core 25, Section 1, porcellanite occurs at the base of a turbidite sequence. Further down the section in Core 33, Section 2 the claystone is darker, harder, and siltier, and porcellanite may be found anywhere within the darker member of the turbidite unit, but usually occurs at the coarser base. Porcellanite only rarely occurs in the upper lighter colored clay member of a turbidite unit. The overall color of the sediment becomes darker with depth, so that by Core $41(588 \mathrm{~m})$ the cyclic alternation consists of olive-gray and olive-black claystones. Coarse detrital minerals, consisting mainly of subangular quartz with some feldspars, heavy minerals and micas, are present at the top of subunit 2a. However, silt and sand are most common below Core $32(446 \mathrm{~m})$. Throughout the lower part of the subunit (Cores 32 through 49), silt and sand laminae and thin beds, sometimes graded, occur at the base of the darker beds. Here, the cyclicity begins to take on the more obvious aspects of turbidites. Also, between Cores 32 and 44, the sediments become harder, which may reflect increased carbonate cementation. Thin (about $10 \mathrm{~cm}$ ) beds of siderite (?) are found in
Cores 41 and 44 . The cyclic interbeds are particularly distinct at the base of the subunit (Cores 44 through 47) (averaging about 20 cycles per $1.5 \mathrm{~m}$ ), and siderite(?)cemented, "dirty" sandstones often occur at the bases of darker interbeds. Loadcasts are developed at the bases of some sandstone laminae and thin beds. Throughout most of the subunit, the upper, lighter colored member of a cyclic couplet contains fine, wispy laminae and floating silt-size quartz grains. The silt is often concentrated in burrows or in thin currentwinnowed laminae. Pyrite is present as a rare component in most smear slides from Subunit 2a, and occasionally occurs as megascopic aggregates and rosettes (an excellent example occurs in Core 30, Section 1). Black, manganese (?) staining is common throughout the subunit as liesegang burrow halos, flecks, streaks, and fine laminae.

Subunit 2b-Interbedded Red and Green Shales (Cores 50-52)

Subunit $2 \mathrm{~b}$ consists of interbedded dark reddish brown $(10 \mathrm{R} 2 / 3)$ and grayish blue-green (5BG5/2) shale. Small concretions of dolomite (?)-cemented sandstone occur in Core 52 . The subunit is probably bioturbated throughout, but burrows are only visible near the contacts of different colored beds where one color is mixed into another. Smear slides of sediments from this subunit contain a variable coarse clastic component consisting mainly of rare to abundant iron oxidestained quartz. Pyrite occurs in the green beds throughout the subunit.

\section{Subunit 2c-Olive, Silty, Sandy Claystone and Shale (Cores 53 through 59, and Nodular Limestone in the Top $5 \mathrm{~cm}$, Section 1 of Core 60)}

Subunit $2 \mathrm{c}$ has essentially the same composition as the base of Subunit 2a; the two are simply separated by the red and green shale of Subunit $2 b$. The upper part of Subunit 2c consists of cyclic interbeds of green and olive claystone. Coarse "dirty" sandstone laminae (often cemented by carbonate) occur at the bases of many of the darker interbeds. The frequency and thickness of these sandstone laminae and thin beds increase downward within the subunit. Smear slides of sandstones from the base of Subunit 2c contain dominant subrounded, fairly well-sorted quartz, abundant clay, and rare feldspars, heavy minerals, micas, plant debris, pyrite, dolomite rhombs, and fish debris. The clay beds have fairly well-developed fissility in Cores 57 through 59. Core 59 and Sample 58, CC contain several thin nodular limestone beds consisting of fibroradiate nodules of iron-rich and iron-poor calcite (indicated by staining) in a matrix of green clay.

\section{Unit 3-Black Carbonaceous Shale With Diabase Sills (Cores 60 through 63)}

The lowermost unit consists of dark gray to black (N5-N1) shale with interbedded diabase sills. Smear slides of the black shale contain abundant organic debris which often obscures the other material. Other components observed are dominant clay and rare to common quartz and pyrite. Core 63, the lowermost core of Site 368, contains rare planktonic foraminifers, nannofossils, and radiolarians concentrated in quartzsilt laminae. 


\section{Shipboard Description of Basaltic Rocks ${ }^{3}$}

\section{Eremeev}

Thin, fine-grained basic intrusive sills occur in Core 60 , Section 2, 0 to $10 \mathrm{~cm}$, and Core 60 , Section 4,75 to $85 \mathrm{~cm}$. One coarse-grained diabase sill extends from Core 60 , Section $5,115 \mathrm{~cm}$, to Core 62 , Section $3,7 \mathrm{~cm}$ (total thickness of about $12.5 \mathrm{~m}$ ). Contacts between the uppermost thin sills and the black shales are generally sharp, with little apparent effect due to baking. Calcite veins occur in these smaller sills, and a small pyrite vein occurs at the upper contact of the small sill at the base of Core 60, Section 1. The upper contact between the thick, coarse-grained sill and overlying black shale shows only $20 \mathrm{~cm}$ of baking, mainly in the form of a slightly lighter color of the shale (Core 60, Section 5). However, baking at the lower contact of the thick sill with the underlying black shale has affected the shale for at least $90 \mathrm{~cm}$. The shale in this $90-\mathrm{cm}$ interval is considerably harder, lighter in color, and contains several dark red bands, perhaps due to oxidation of pyrite (Core 63, Section 3).

Three rock types were recognized, based on study of thin sections of the sills. A description of each of these three types follows:

Type I: Olivine Diabase (TS 41-368-60, CC; 41-368-5, $139-141 \mathrm{~cm}):$

Type I diabases consist of plagioclase, olivine, pyroxene, hornblende, chlorite, magnetite, ilmenite, quartz, and calcite.

The olivine diabases have a hypidiomorphic granular texture. Most of the plagioclase crystals range in composition between $\mathrm{An}_{35}$ and Anoo. Crystals of plagioclase are usually very clear, but in one thin section they are thoroughly altered to cloudy masses of chorite, zoisite, and epidote. The pyroxenes are generally hypersthene and augite which crystallized at about the same time but after the plagioclase. Crystals of hypersthene often enclose grains of olivine and plagioclase. Bluish green amphibole, greenish brown hornblende, and brown ferrochlorite are ubiquitous and represent late reaction products. Ilmenite and magnetite form euhedral crystals or skeletal grains. Quartz is intergrown with augite or occurs interstitially in the plagioclase. Calcite occupies space between the laths of feldspar.

Type II: Olivine diabase (TS 41-368-60-6, 60-62 cm):

Type II diabases consist of plagioclase, pyroxene, olivine, basaltic hornblende, iron oxides glass, chlorite, and serpentine.

Most of the plagioclase laths range between $\left(\mathrm{An}_{s_{0}}\right)$ and $\left(\mathrm{An}_{60}\right)$ (labradorite). Pyroxenes are generally augite and are marginally altered to serpentine.

Olivine forms large crystals entirely altered to talc and serpentine. Interstitial material is usually hornblende, chlorite, calcite, and chalcedony. The iron oxides are intergrowths of ilmenite, magnetite, and hematite. They occupy spaces between the feldspar

\footnotetext{
${ }^{3}$ See separate chapter by J. Natland, this volume.
}

laths. Ilmenite, magnetite, and hematite form euhedral crystals and skeletal grains, and are usually intergrown with pyroxenes.

Type III: Tholeiitic basalts (TS 41-368-60-1, 143-145 $\mathrm{cm}$; 41-368-60-5, 104-106 cm):

The tholeiitic basalts consist of plagioclase, basaltic hornblende, palagonite, and serpentine.

The plagioclases of the tholeiitic basalts are labradorite (An $50-\mathrm{An}_{60}$ ). Palagonite, sideromelance, chlorophaeite, and serpentine occupy spaces between the feldspar laths. Calcite and chalcedony accompany the basaltic hornblende.

\section{Summary}

Sediments recovered at Site 368 consist of a relatively thick hemipelagic facies characteristic of a continental margin. One of the most striking features of the sediments is their cyclicity (see Dean et al, this volume). Most of the cycles, especially those of the dominant lithology (Unit 2), are the result of turbidity currents. Dilution cycles in Subunit $1 \mathrm{~b}$ may represent dilution by fine material from turbidity currents. The clear evidence for deposition by turbidity current suggests that much, if not all, of the cyclicity which is so characteristic of all of Unit 2 (265.5 to $950 \mathrm{~m}$, lower Miocene to Upper Cretaceous?) is the result of cyclic influx of terrigenous material. These turbidites are best developed at the base of Subunit 2a (Cores 38 through 47,560 to $655 \mathrm{~m}$ ) and in Subunit 2c (Cores 53 through 59,750 to $950 \mathrm{~m}$ ). There, a silt or sand layer often forms the base of a turbidite and load casts are more frequent than in the overlying sediments. However, the main turbidite cyclicity, occurring an average of about 12 cycles per 1.5 meters, continues throughout Unit 2 . Porcellanite and chert are most often found at the bases of the dark turbidite layers, suggesting that chert formation may be favored by high permeability (See Dean et al., this volume). The fact that turbidites continue throughout Unit 2, but exist only as clay cycles in the upper part, suggests that the carbonateargillaceous cycles at the base of Subunit 1b (i.e., nannofossil ooze-marl and nannofossil marl-clay cycles) are also due to pulsing of terrigenous materials, but of a much finer grain size. These cycles therefore appear to be the result of dilution and not dissolution.

The altenation of red and green shales of Subunit $2 b$ still represents a problem because it cannot be adequately explained by clastic fluctuations or dissolution. The cycles of Subunit $2 \mathrm{~b}$ are probably the result of fluctuating redox conditions within the sediments, and are therefore analogous to the cycles of red and green shale described from Site 367 (this volume).

The black carbonaceous shale interbedded with diabase and basalt sills in Unit 3 are similar to the late Aptian-early Albian to early Turonian black shale in Unit 4, Site 367 (this volume). The shale contains abundant organic matter (as high as $11.7 \%$ organic carbon, and $\mathrm{C} / \mathrm{N}$ ratios as high as 74 ) which has apparently undergone an increase in maturation due to the local increase in the thermal gradient related to instrustion of the sills (see Kvenvolden and related papers, this volume). 


\section{GEOCHEMICAL MEASUREMENTS}

The analytical techniques used in the analyses discussed below are given in the Introduction to this volume.

\section{Organic Carbon and $\mathrm{C} / \mathrm{N}$ Ratios}

Carbonate and light colored clay facies were low in organic carbon (less than $0.5 \% \mathrm{C}$ ) and correspondingly lower in $\mathrm{C} / \mathrm{N}$ ratio (usually less than 10). The dark green to black claystones and shales contained significantly higher organic carbon $(0.5 \%$ to $11.7 \% \mathrm{C})$ and $\mathrm{C} / \mathrm{N}$ ratios (10 to 74 ). Highest organic contents and ratios are in the black shales. Complete results are given in Table 3.

Perhaps the most interesting feature of this site is the diabase sills intruded into the organic-rich black shale

TABLE 3

Carbon and Nitrogen Analyses for Site 368

\begin{tabular}{|c|c|c|c|c|c|c|}
\hline \multirow{2}{*}{$\begin{array}{c}\text { Sample } \\
\text { (Interval in cm) }\end{array}$} & \multirow{2}{*}{$\begin{array}{l}\text { Depth } \\
\text { (m) }\end{array}$} & \multicolumn{2}{|c|}{$\begin{array}{c}\text { \% Organic C } \\
\text { (total dry wt. basis) }\end{array}$} & \multicolumn{2}{|c|}{$\begin{array}{c}\mathrm{C} / \mathrm{N} \\
\text { (atomic ratio) }\end{array}$} & \multirow[b]{2}{*}{ Remarks $^{a}$} \\
\hline & & $x$ & SD & $x$ & SD & \\
\hline $1-4,62-63$ & 5 & 0.391 & 0.011 & 9.4 & 0.97 & Nanno ooze \\
\hline $2-3,29-30$ & 15 & 0.172 & 0.004 & 8.9 & 2.07 & Nanno ooze \\
\hline $2-3,82-83$ & 15 & 0.393 & 0.071 & 11.2 & 3.14 & Nanno ooze \\
\hline $3-5,0$ & 53 & 0.107 & 0.011 & 5.3 & 0.49 & Foram nanno \\
\hline $8-3,130$ & 185 & 0.117 & 0.011 & 5.2 & 0.24 & Nanno marl \\
\hline $9-3,87-88$ & 195 & 0.055 & 0.003 & 1.9 & 0.26 & Nanno marl \\
\hline $9-3,126-127$ & 195 & 0.032 & 0.003 & 1.2 & 0.15 & Clay \\
\hline $11-1,102-103$ & 215 & 0.089 & 0.014 & 2.4 & 0.38 & Clay \\
\hline $11-1,129-130$ & 215 & 0.065 & 0.021 & 2.9 & 0.68 & Clay \\
\hline $15-3,130$ & 255 & 0.043 & 0.001 & 2.0 & 0.03 & Clay \\
\hline $18-5,130$ & 280 & 0.069 & 0.017 & 2.0 & 0.55 & \\
\hline $22-4,37-38$ & 330 & 0.220 & 0.012 & 6.3 & 0.19 & \\
\hline $22-4,32-33$ & 330 & 0.815 & 0.042 & 13.4 & 1.39 & \\
\hline $27-2,130$ & 390 & 0.937 & 0.037 & 12.1 & 0.27 & \\
\hline $27-2,147-150$ & 390 & 1.150 & - & - & - & Leco-Shell \\
\hline $32 \cdot 2,130$ & 445 & 0.084 & 0.017 & 3.5 & 0.72 & \\
\hline $37-3,130$ & 535 & 0.505 & 0.029 & 8.9 & 0.47 & \\
\hline $40-4,131-132$ & 585 & 1.048 & 0.071 & 14.5 & 1.03 & \\
\hline $43-2,130$ & 615 & 1.032 & 0.057 & 14.5 & 0.32 & \\
\hline $46-3,74-75$ & 640 & 0.390 & 0.023 & 5.5 & 0.79 & Clay \\
\hline $46-3,79-80$ & 640 & 1.578 & 0.001 & 18.0 & 0.14 & Clay \\
\hline $50-3,38-39$ & 710 & 0.151 & 0.038 & 2.7 & 0.65 & Clay \\
\hline $50-3,46-47$ & 710 & 0.056 & 0.001 & 1.6 & 0.03 & Clay \\
\hline $51 \cdot 2,130$ & 720 & 0.118 & 0.048 & 2.5 & 0.93 & \\
\hline $51-2,150$ & 720 & 0.128 & 0.002 & 2.5 & 0.36 & \\
\hline $56-3,64-65$ & 845 & 0.115 & 0.002 & 4.2 & 0.19 & \\
\hline $57-2,93-94$ & 900 & 0.086 & 0.029 & 0.6 & 0.21 & \\
\hline $57-3,82-84$ & 900 & 0.059 & 0.015 & 1.1 & 0.26 & \\
\hline $58-4,130$ & 930 & 0.302 & 0.069 & 6.0 & 1.04 & \\
\hline $60-2,13-14$ & 955 & 0.440 & - & 1.84 & - & TAMU \\
\hline $60-2,66-67$ & 955 & 0.965 & 0.003 & 10.4 & 0.67 & Shale \\
\hline $60-2,135-136$ & 956 & 1.910 & - & 28.0 & - & TAMU \\
\hline $60-3,17-18$ & 957 & 1.477 & - & 14.5 & - & Shale \\
\hline $60-3,75-76$ & 957 & 1.860 & - & 14.2 & - & TAMU \\
\hline $60-3,119-120$ & 958 & 2.780 & - & 27.2 & - & TAMU \\
\hline $60-4,39-40$ & 958 & 3.390 & 0.346 & 13.6 & 1.54 & Shale \\
\hline $60-4,70-71$ & 958 & 5.090 & - & 42.7 & - & TAMU \\
\hline $60-4,110-111$ & 959 & 2.180 & - & 38.4 & - & TAMU \\
\hline $60-4,120-122$ & 959 & 3.228 & 0.108 & 38.6 & 4.35 & Shale \\
\hline $60-5,24-25$ & 959 & 3.730 & - & 18.2 & - & TAMU \\
\hline $60-5,43-44$ & 959 & 3.362 & 0.024 & 74.2 & 1.24 & Shale \\
\hline $60-5,83-84$ & 960 & 3.150 & - & 138.6 & - & TAMU \\
\hline $60-5,90-91$ & 960 & 0.199 & - & 1.1 & - & TAMU \\
\hline $60-5,103-104$ & 960 & 0.148 & 0.080 & 3.9 & 0.32 & Baked zone near sill \\
\hline $62-3,60-61$ & 974 & 0.356 & - & 15.4 & - & TAMU \\
\hline $62-3,70-71$ & 974 & 0.326 & - & 14.1 & - & TAMU \\
\hline $62-3,80-81$ & 974 & 0.685 & - & 19.9 & - & TAMU \\
\hline $62-3,93-94$ & 974 & 2.910 & - & 128.0 & - & TAMU \\
\hline $62-3,100-102$ & 975 & 1.797 & 0.299 & 13.6 & 2.65 & Shale \\
\hline $62-4,12-13$ & 975 & 2.599 & 0.050 & 19.5 & 0.50 & Shale \\
\hline $62-4,105-106$ & 976 & 11.718 & 0.566 & 19.2 & 0.34 & Shale \\
\hline $63-1,120-121$ & 978 & 1.650 & - & 20.7 & - & TAMU \\
\hline $63-1,140-141$ & 978 & 2.000 & - & 17.6 & - & TAMU \\
\hline $63-2,62-63$ & 979 & 1.548 & 0.074 & 13.1 & 0.25 & Shale \\
\hline $63-3,130$ & 980 & 1.434 & 0.019 & 12.7 & 0.94 & \\
\hline $63-3,147-150$ & 980 & 1.110 & - & - & - & Leco-Shell \\
\hline $63-4,94-95$ & 981 & 2.906 & 0.003 & 20.3 & 1.60 & Shale \\
\hline
\end{tabular}

${ }^{a}$ TAMU indicates sample analyzed at Texas A\&M University. Leco-Shell indicates a sample analyzed by the Leco method at Shell Development Corp., Houston, Texas. in Cores 60 to 62. Samples taken in Core 60, Sections 4 and 5 , just above the major sill and below the minor sill, indicate a possible "distillation" of organic matter away from the baked zone above the major sill. A corresponding feature is found in Core 62, Section 4, where organic carbon content reaches $11.7 \% \mathrm{C}$. Further discussion of the changes in organic matter is found in Baker et al. (this volume).

A sample from Core 63 had a petroliferous odor and fluorescent matter was extractable with a few drops of a non-polar solvent (1, 2-dichloroethane). Also, a 15-g sample (Core 63, Section 2, 20-21 cm) was extracted for 24 hours in a Soxhlet-apparatus with 1, 2dichloroethane. A dark brown residue was recovered from the solvent, which gave a bright blue-green fluorescence to long-wave UV.

\section{Interstitial Gas}

Table 4 summarizes the gas analyses for this site. No propane or higher hydrocarbons were detected. Ethane was present only in low levels or entirely undetectable except near the sill. Intrusion of the sill should have given rise to thermal cracking of the organic matter producing measureable quantities of isobutane and higher hydrocarbons. These may have been present at undetectable levels $(<100 \mathrm{ppm})$ or they were not released from the sediments as rapidly as methane or ethane. Cores gave off gas up to $60 \mathrm{~min}$. after splitting.

\section{Carbonate Bomb Analysis}

Results from carbonate bomb analyses are given in Table 5 and Figure 5. The higher carbonate values in the upper sediment section correspond to nannofossil ooze and marl. Clay and claystones predominate between 300 and 550 subbottom; consequently, very low carbonate values occur. However, smear slides from this zone indicated possible dolomite or siderite. The sharp spike $\left(81 \% \mathrm{CaCO}_{3}\right)$ in Core 40 , Section 4 , is in a layer rich in these minerals.

\section{Interstitial Water Chemistry}

Results from interstitial water chemical analyses are given in Table 6 and Figure 6. Chlorinity measurements correspond to salinity except for two measurements.

\section{PHYSICAL PROPERTIES}

\section{Bulk Properties}

Bulk property measurements were made for water content, porosity, void ratio, bulk density, and specific gravity of solids. These data are tabulated in Trabant (this volume).

It appears that three major cycles occur within the bulk property data (Figure 7). The porosity values are unusually high (up to $70 \%$ ) within three zones, labeled I, II, III. This phenomena may be the result of drilling disturbance or under compaction. Zone I represents a transition zone from nannofossil ooze and marl to silty clay at a depth of 240 meters. This zone also includes a Miocene volcanic shard layer. Zone II at a depth of 350 meters appears to be associated with the onset of a clastic unit and the presence of numerous fine sand 
TABLE 4

Interstitial Gas Analyses for Site 368

\begin{tabular}{|c|c|c|c|c|c|c|c|c|}
\hline $\begin{array}{c}\text { Sample } \\
\text { (Interval in } \mathrm{cm} \text { ) }\end{array}$ & $\begin{array}{l}\text { Subbottom } \\
\text { Depth }\end{array}$ & $\mathrm{N}_{2}+\mathrm{O}_{2}$ & $\mathrm{CH}_{4}$ & $\mathrm{CO}_{2}$ & $\begin{array}{l}\mathrm{C}_{2} \mathrm{H}_{6} \\
\text { (Carle) }\end{array}$ & $\begin{array}{c}\mathrm{C}_{2} \mathrm{H}_{6} \\
\text { (Bendix) }\end{array}$ & $\mathrm{C}_{3} \mathrm{H}_{8}$ & $\frac{M}{E+P}$ \\
\hline & $\begin{array}{c}\text { Bottom of } \\
\text { Core }(\mathrm{m})\end{array}$ & \multicolumn{2}{|c|}{ (\% of total) } & \multicolumn{4}{|c|}{ (ppm of total gas) } & \\
\hline $22-3,75$ & 332 & 79.3 & 1.6 & 191000 & - & - & & - \\
\hline $23-2,0$ & 360 & 19.0 & 77.0 & 36000 & - & - & & - \\
\hline $25-1,90$ & 375 & 6.7 & 93.0 & 4588 & 713 & 418 & & 2224 \\
\hline $26-2,75$ & 385 & 2.6 & 96.8 & 4650 & 210 & - & & 4600 \\
\hline $27-33,30$ & 395 & 33.0 & 64.0 & 24000 & - & - & & - \\
\hline $33-2,75$ & 455 & 14.1 & 85.1 & 7674 & - & - & & - \\
\hline $38-3,75$ & 570 & 6.9 & 92.5 & 5314 & - & - & & - \\
\hline $39-6,75$ & 579 & 3.1 & 96.4 & 3646 & - & - & & - \\
\hline $40-4,110$ & 589 & 2.8 & 96.8 & 3891 & - & - & & - \\
\hline $42-3,105$ & 608 & 4.9 & 94.5 & 5641 & - & - & & - \\
\hline $43-4,100$ & 617 & 10.3 & 89.0 & 6509 & - & - & & - \\
\hline $46-4,0$ & 645 & 4.2 & 95.3 & 4560 & $\mathrm{Tr}^{\mathrm{a}}$ & $\mathrm{Tr}^{\mathrm{a}}$ & & - \\
\hline $47-4,100$ & 655 & 3.6 & 95.9 & 5023 & - & $\mathrm{Tr}^{\mathrm{a}}$ & & - \\
\hline $58-5,100$ & 930 & 2.7 & 97.0 & 1881 & 622 & 296 & & 3276 \\
\hline $59-3,60$ & 948 & 2.4 & 97.2 & 1934 & 1781 & 1786 & & 544 \\
\hline $60-4,75$ & 959 & 2.7 & 97.0 & 144 & 2934 & 2064 & & 470 \\
\hline $62-4,100$ & 975 & 5.6 & 94.1 & 1651 & 1382 & 1542 & & 610 \\
\hline $63-2,100$ & 985 & 3.7 & 95.8 & 2081 & 2732 & 2941 & & 325 \\
\hline
\end{tabular}

${ }^{\mathrm{a}} \mathrm{Tr}$ - Trace

turbidites which have porosities on the order of $73 \%$. The first cherts appear in Zone II. Zone III, at a depth of 525 meters, represents a sequence with more abundant turbidites and maximum porosities on the order of $68 \%$. Porosities within the chert vary from $7 \%$ to $26 \%$ whereas the diabase has a value of $17 \%$.

\section{Shear Strengths}

Miniature vane shear, hand vane, and penetrometer data were collected down to a depth of 275 meters, where stiff clays finally broke one of the vanes. Only a few measurements were made in the upper 100 meters because of disturbance. An exception is where chunks of "undisturbed" material are present. Shear strengths ranged from $0.25 \mathrm{~kg} / \mathrm{cm}^{2}$ to over $5 \mathrm{~kg} / \mathrm{cm}^{2}$, progressively increasing down to 200 meters. The values rise rapidly beyond the range of the testing apparatuses below 200 meters depth. The volcanic ash zones have values of $1.05 \mathrm{~kg} / \mathrm{cm}^{2}$.

A rapid increase in shear strength below $225 \mathrm{~m}$ corresponds to the transition from nannofossil ooze and marls to clay and claystone of lithologic Subunit 2a.

\section{Acoustic Velocities}

Velocities within the upper ooze and marl ( 0 to 240 $\mathrm{m}$ ) as well as those from the lower gassy claystone units, are poor due to the sample disturbance. The effects of coring disturbance and the release of dissolved gasses from interstitial pore water cannot be assessed in order to correct the velocity data. The velocity values obtained within the clay and claystone of lithologic Subunit 2a range from 1.43 to $2.46 \mathrm{~km} / \mathrm{sec}$, which should be accepted as minimum values.

The chert zones exhibit high velocities which range from 2.83 to $5.01 \mathrm{~km} / \mathrm{sec}$. However, these layers represent only a small percentage of the retrieved cores.
Attempts to measure velocities within the volcanic shard zones were unsuccessful due to strong attenuation effects.

Velocity measurements within the sequence of baked black shale above and below the diabase sills averaged just over $3.0 \mathrm{~km} / \mathrm{sec}$. The fine-grained diabase $(20 \mathrm{~cm}$ thick sequence in Core 60 ) produced a velocity between 3.5 and $3.6 \mathrm{~km} / \mathrm{sec}$ measured both horizontally and vertically, indicating no acoustic anisotropy. The coarser diabase from the lower sill has a velocity of 4.64 $\mathrm{km} / \mathrm{sec}$.

\section{Summary}

The thick sequence of clay and fine-grained turbidites of Site 368 provides an interesting setting for the study of the effects of compaction within these sediments. The almost complete absence of carbonates is of interest because very little secondary diagenetic effects, such as cementation (e.g., siderite, dolomite, and porcellanite), appear to be present.

Poor velocity data were obtained within the clay because of disturbance by drilling and the release of gas. Shear strength values were obtained down to a depth of $275 \mathrm{~m}$, where the sediment became too stiff to be measured. Porosity values remain high throughout the entire sequence of clay. They range from $75 \%$ near the surface to $32 \%$ within the lowermost black shale unit. Three zones of relatively high porosities, perhaps due to undercompaction, appear to be associated with variations in lithology.

\section{BIOSTRATIGRAPHIC SUMMARY}

The three principal groups of microfossils (foraminifers, nannofossils, radiolarians) allow age determinations within the Quaternary, Pliocene, Miocene, lower to middle Eocene, and Albian to Turonian. Other parts of the section contain only 
TABLE 5

Carbonate Analyses Using Carbonate Bomb Method for Site 368

\begin{tabular}{|c|c|c|c|}
\hline $\begin{array}{c}\text { Sample } \\
\text { (Interval in } \mathrm{cm} \text { ) }\end{array}$ & $\begin{array}{l}\text { Depth } \\
\text { (m) }\end{array}$ & $\% \mathrm{CaCO}_{3}$ & Lithology \\
\hline $1-3,87-88$ & 10 & 48 & Foram nanno marl \\
\hline $2-3,90-91$ & 20 & 54 & Nanno ooze \\
\hline $3-3,80-81$ & 50 & 68 & Nanno ooze \\
\hline $4-3,82-83$ & 90 & 65 & Nanno marl \\
\hline $5-3,65-66$ & 130 & 86 & Nanno ooze \\
\hline $6-3,58-59$ & 140 & 82 & Nanno ooze \\
\hline $7-3,42-44$ & 175 & 74 & Nanno ooze \\
\hline $7-3,112-113$ & 175 & 49 & Nanno marl \\
\hline $8-5,88-89$ & 190 & 13 & Silty nanno marl \\
\hline $9-3,7-8$ & 195 & 25 & Nanno marl \\
\hline $10-2,52-53$ & 205 & 13 & Clay \\
\hline $11-3,52-53$ & 215 & 31 & Nanno marl \\
\hline $13-4,74-75$ & 235 & 13 & Silty clay \\
\hline $14-3,62-63$ & 245 & 23 & Nanno marl \\
\hline $15-3,32-33$ & 255 & 0 & Clay \\
\hline $17-3,71-72$ & 270 & 11 & Silty clay \\
\hline $17-6,135-136$ & 275 & 0 & Silty clay \\
\hline $18-3,90-91$ & 280 & 0 & Silty clay \\
\hline $19-3,100-101$ & 290 & 0 & Clay \\
\hline $21-2,92-93$ & 320 & 13 & Clay \\
\hline $22-3,74-75$ & 325 & 9 & Claystone \\
\hline $22-5,135-136$ & 330 & 9 & Claystone \\
\hline $28-1,96-97$ & 400 & 7 & Claystone \\
\hline $29-1,84-85$ & 415 & 3 & Claystone \\
\hline $31-3,121-122$ & 435 & 0 & Claystone \\
\hline $32-3,99-100$ & 445 & 0 & Claystone \\
\hline $34-2,140-142$ & 470 & 4 & Claystone \\
\hline $36-3,105-107$ & 520 & 4 & Claystone \\
\hline $37-5,9-10$ & 540 & 1 & Claystone \\
\hline $38-3,80-81$ & 565 & 0 & Claystone \\
\hline $39-3,47-48$ & 575 & 1 & Claystone \\
\hline $40-4,141-142$ & 585 & 81 & Dolomite or siderite \\
\hline $41-3,111-112$ & 595 & 0 & Claystone \\
\hline $42-3,93-94$ & 605 & 10 & Porcellinite \\
\hline $43-4,68-69$ & 615 & 3 & Claystone \\
\hline $44-3,111-112$ & 620 & 0 & Claystone \\
\hline $45-3,67-68$ & 630 & 1 & Claystone \\
\hline $46-3,146-147$ & 640 & 0 & Claystone \\
\hline $47-3,121-122$ & 650 & 0 & Claystone \\
\hline $50-2,69-70$ & 710 & 0 & Shale \\
\hline $51-3,53-54$ & 720 & 0 & Shale \\
\hline $52-4,77-78$ & 730 & 0 & Shale \\
\hline $52-4,112-113$ & 730 & 0 & Shale \\
\hline $53-3,132-133$ & 750 & 0 & Silty claystone \\
\hline $54-4,70-71$ & 800 & 0 & Silty claystone \\
\hline $55-3,58-59$ & 845 & 0 & Claystone \\
\hline $57-4,131-132$ & 900 & 0 & Shale \\
\hline $58-3,84-85$ & 930 & 0 & Shale \\
\hline $59-3,93-94$ & 945 & 0 & Sandy claystone \\
\hline $60-4,48-49$ & 955 & 1 & Shale \\
\hline $63-3,127-128$ & 980 & 19 & Shale \\
\hline
\end{tabular}

benthic agglutinated foraminifers or are completely barren of microfossils. Scattered quantities of fish debris are present in many of the otherwise unfossiliferous sections. The age of these stratigraphic intervals can only be estimated, based on a more exact age of overlying and underlying layers, and extrapolation to other DSDP sites and the known terrestrial geology of Africa.

Preservation of calcareous microfossils is generally good in the Neogene section, but, in the underlying Paleogene and Upper Cretaceous sediments, the calcareous microfossils are either entirely missing or

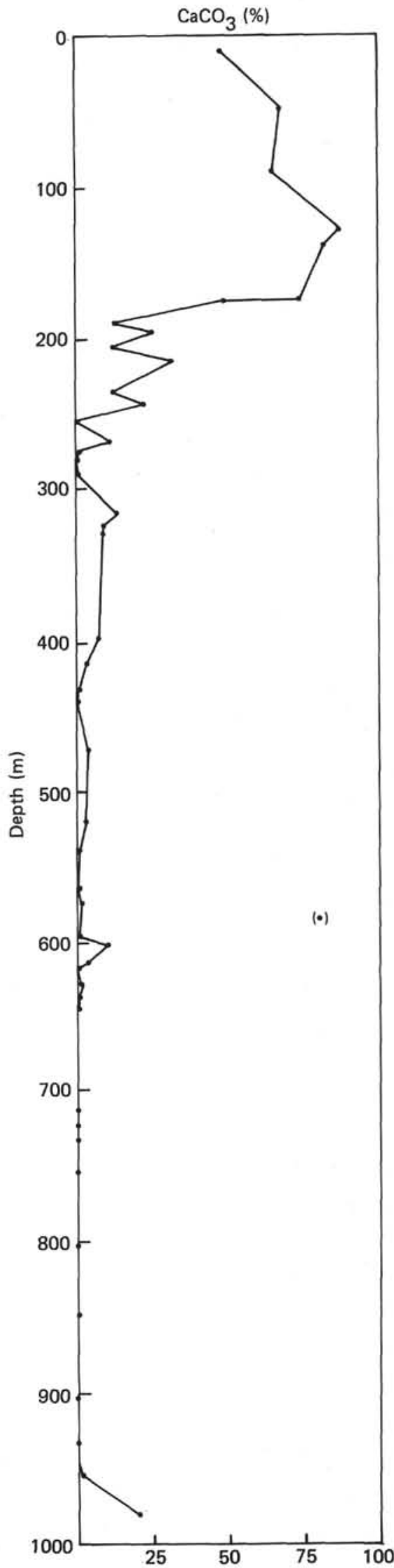

Figure 5. Plot of carbonate versus depth for Site 368. 
TABLE 6

Summary of Interstitial Water Analyses for Site 369

\begin{tabular}{|c|c|c|c|c|c|c|c|c|}
\hline $\begin{array}{c}\text { Sample } \\
\text { (Interval in } \mathrm{cm} \text { ) }\end{array}$ & $\begin{array}{l}\text { Subdepth } \\
\text { (m) }\end{array}$ & $p \mathrm{H}$ & $\begin{array}{l}\text { Alkalinity } \\
\text { (meq } / \mathrm{kg} \text { ) }\end{array}$ & $\begin{array}{c}\text { Salinity } \\
(\% \circ) \\
\text { per mil }\end{array}$ & $\underset{(\text { mmoles/1) }}{\mathrm{Ca}^{++}}$ & $\begin{array}{c}\mathrm{Mg}^{++} \\
(\text {mmoles } / 1)\end{array}$ & $\begin{array}{c}\mathrm{Cl}^{-} \\
(\% \circ) \\
\text { per mil }\end{array}$ & $\begin{array}{l}\text { Remarks } \\
(\mathrm{Mg} / \mathrm{Ca})\end{array}$ \\
\hline $1-4,144-150$ & 7.5 & 7.58 & 3.73 & 35.2 & 10.50 & 51.75 & 20.22 & 4.93 \\
\hline $3-4,0-6$ & 55.0 & 7.41 & 4.40 & 34.6 & 8.54 & 47.81 & 19.95 & 5.60 \\
\hline $5-4,144-150$ & 131.0 & 7.50 & 3.48 & 33.0 & 5.70 & 39.66 & 19.71 & 6.91 \\
\hline $6-5,144-150$ & 169.0 & 7.55 & 3.10 & 32.0 & 5.97 & 35.47 & 19.71 & 5.94 \\
\hline $8-4,144-150$ & 188.0 & 7.61 & 2.55 & 31.9 & 6.31 & 34.71 & 20.26 & 5.50 \\
\hline $13-2,144-150$ & 234.0 & 7.76 & 2.28 & 31.9 & 7.74 & 32.54 & 20.50 & 4.20 \\
\hline $18-5,144-150$ & 283.0 & 8.47 & 2.75 & 32.0 & 9.60 & 30.23 & 19.72 & 3.15 \\
\hline $23-1,144-150$ & 359.0 & 7.92 & 3.75 & 32.2 & 11.76 & 29.84 & 19.54 & 2.54 \\
\hline $32-4,144-150$ & 444.0 & 7.85 & 3.20 & 32.4 & 11.30 & 31.03 & 19.71 & 2.75 \\
\hline $34-2,144-150$ & 473.0 & 7.72 & 2.62 & 32.4 & 10.22 & 33.44 & 19.78 & 3.27 \\
\hline $36-2,144-150$ & 520.0 & 7.70 & 2.40 & 32.4 & 9.19 & 36.54 & 19.95 & 3.98 \\
\hline $39-5,144-150$ & 577.0 & 7.61 & 1.69 & 32.0 & 8.99 & 36.37 & 19.88 & 4.05 \\
\hline $46-4,144-150$ & 644.0 & 7.30 & 1.62 & 31.9 & 10.40 & 36.81 & 20.02 & 3.54 \\
\hline $52-4,144-150$ & 730.0 & 8.33 & 1.59 & 31.7 & 13.11 & 35.72 & 19.75 & 2.72 \\
\hline
\end{tabular}

present in rare amounts and very poorly preserved. Siliceous microfossils are present in substantial quantities only within the upper Pleistocene, middle Miocene, and lower to middle Eocene. Elsewhere, siliceous microfossils are either absent or are present as trace amounts of pyritized and poorly preserved fragments.

\section{Foraminifers}

Planktonic and benthic foraminifers are found in sediments of Holocene to Turonian to Albian age, but their character, abundance, and preservation vary. Based on these features, the following five biostratigraphic units may be recognized: Quaternary to upper Miocene, middle to lower Miocene, lower Miocene to Paleocene?, Paleocene to Upper Cretaceous, and Turonian to Albian.

\section{Cenozoic}

Planktonic foraminifers are abundant and well preserved in the upper part of the Holocene to upper Miocene sequence, but become less abundant and only moderately preserved in the lower part. The rich assemblages of planktonic foraminifers allow a very good stratigraphic zonation, but, due to discontinuous coring of this interval, not all zones were recovered. The following stratigraphic subdivisions were recognized:

The Holocene assemblage (Core 1, top) of planktonic foraminifers includes Globorotalia fimbriata, $G$. truncatulinoides, G. cultrata, G. tumida, G. inflata, Globigerinoides ruber (pink and white), Globigerina rubescens (pink), G. bulloides, Orbulina universa, Sphaeroidinella dehiscens, and Globoquadrina dutertrei. The preservation of primitive agglutinated foraminifers (thin-walled Rhabdammina, etc.) confirms the presence of the topmost surface sediments in Core 1, top.

Sample 1, CC through Core 3 are assigned to the Globorotalia truncatulinoides Zone of the Pleistocene and are further subdivided into Globorotalia crassaformis viola Subzone and the Globorotalia crassaformis hessi/Globigerina calida calida Subzone.
Section 1 of Core 4 belongs to the Pliocene Globorotalia miocenica Zone. The last sections of Core 4 (Section 2 to $\mathrm{CC}$ ) belong to the Globorotalia margaritae evoluta Zone of the Pliocene.

All four zones of the upper Miocene were identified. The Globorotalia margaritae margaritae Zone occurs in Cores 5 and 6 (exclusive 6, CC). The Globorotalia plesiotumida Zone is represented in Sample 6, CC and in Core 7 (Sections 1 through 3). The Globorotalia acostaensis Zone is found from Sections 7-4 to Section 9-3. The Globorotalia continuosa Zone (N15) occurs in Section 9-4 to Section 10-2. The benthics are rare relative to planktonic foraminifers, but have a high species diversity. The character of planktonic and benthic foraminifers and their ratios indicate a deep water environment well above the carbonate compensation depth.

Abundances of middle to lower Miocene planktonic foraminifers vary from rare to few or common, and their preservation is poor or moderate. The abundance of foraminifers decreases and the preservation deteriorates with depth. Cores 10 through 14 are assigned to the middle Miocene. Relatively diverse assemblages of planktonic foraminifers in Cores 10 and 13 permit precise determinations within the middle Miocene. Sample 10, CC can be correlated with the Globigerina nepenthes/Globorotalia siakensis Zone (N14). Core 13 belongs to the interval of the Globorotalia peripheroacuta-Globorotalia peripheroronda zones. Lower Miocene assemblages are found in core catchers 15 through 18 . The scarcity and low specific diversity of planktonic foraminifers preclude zonal subdivision of the lower Miocene sediments. Benthic foraminifers are few or common in some samples and sponge spicules and fish debris also occur in this section. Preservation of planktonic foraminifers in this interval is often very poor. Tests are marked by traces of dissolution, or are pyritic casts.

The majority of core-catcher samples from Cores 19 through 49 lack microfossils. Some samples contain debris or casts of benthic foraminifers. In Samples 39, CC, 40, CC and 49, CC very rare specimens of $R e$ - 

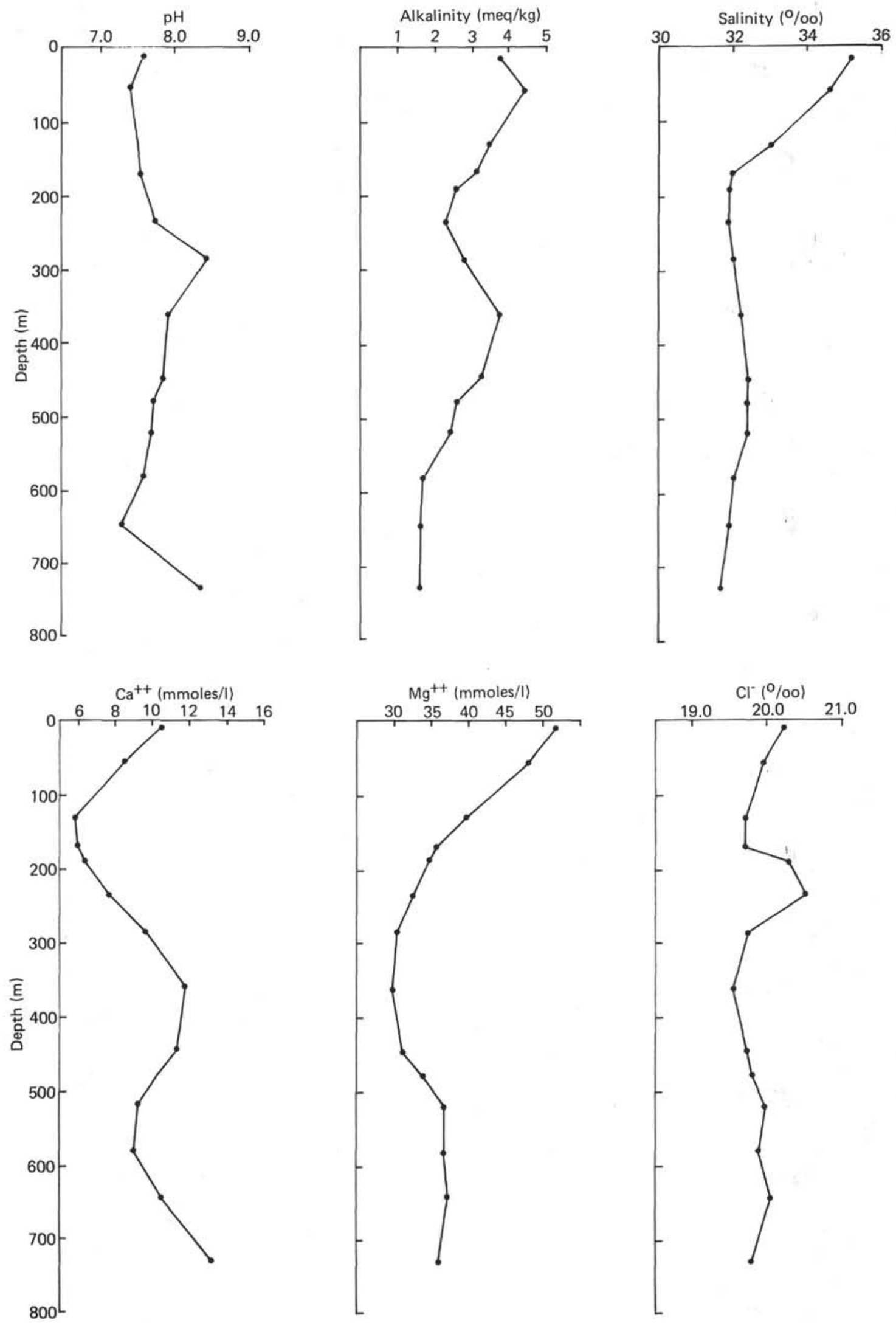

Figure 6. Plots of interstitial water analyses for Site 368. 
$\tilde{+}$

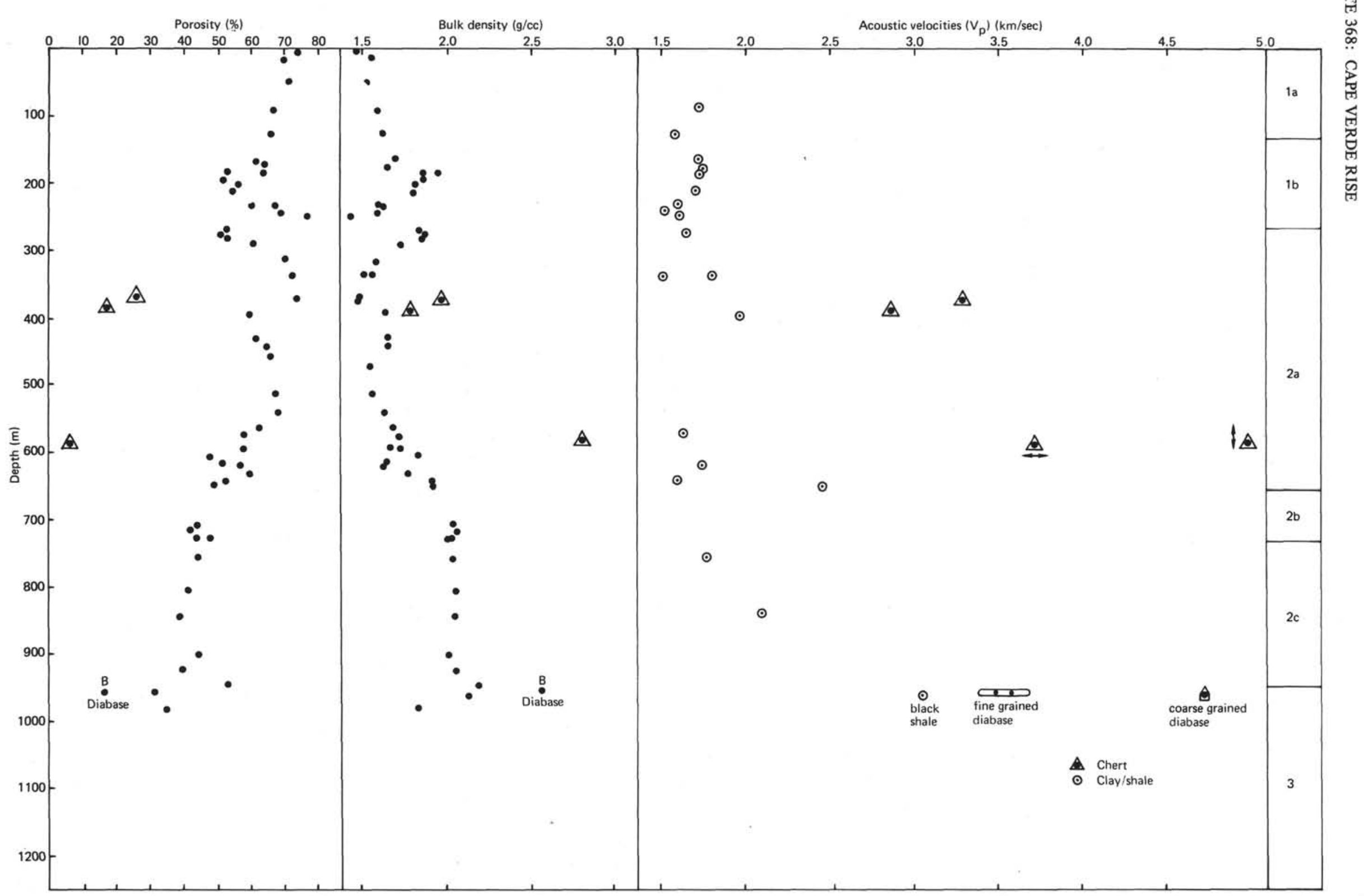

Figure 7. Plots of porosity, bulk density, and velocity versus depth for Site 368. 
curvoides, Saccammina, Rhabdammina, Haplophragmoides, Glomospira, Trochamminoides, Reophax, and Rhizammina are found but the fauna does not permit a direct age determination.

The green-olive and red shale and claystone with intercalations of black shale of Cores 50 through 60 are all characterized exclusively by agglutinated benthic foraminifers. Microfossils are rare to few with poor preservation. Agglutinated foraminifers give an approximate age of Paleocene to Upper Cretaceous. The most primitive agglutinated foraminifers from these non-calcareous sediments suggest a bathyal environment.

\section{Mesozoic}

Cores 62 through 63 contain sporadic agglutinated foraminifers including Rhabdammina, Trochammina, Rhizammina, Haplophragmoides, Recurvoides, and Saccammina. Very thin intercalations of slightly calcareous sediments contain minute poorly preserved planktonic foraminifers. Among these are Hedbergella delrioensis, $H$. planispira, H. amabilis, Globigerinelloides sp., and Heterohelis sp. sp. The fauna can be assigned to the undifferentiated Turonian to Albian stages.

\section{Calcareous Nannoplankton}

The preservation of coccoliths varies from poor to good. Three biostratigraphic intervals were identified: (1) the Pleistocene to lower Miocene (2) the lowermost middle Eocene-upper lower Eocene; and (3) Cretaceous.

\section{Cenozoic}

Pleistocene floras were recovered in the three uppermost cores. The assemblage of coccoliths from the first two cores is rich and is fairly well preserved. The assemblages in Core 1 to Section 3 belong to the Emiliania huxleyi Zone and that of Core 2 belong to the Gephyrocapsa oceanica Zone. Core 3 has an assemblage of coccoliths which falls within the Emiliania annula Subzone of early Pleistocene age. Core 4 contains the Discoaster surculus Subzone. The coccoliths are abundant with moderate preservation, but the discoasters are highly fragmented. No significant overgrowth or dissolution was observed. Core 5 contains Ceratolithus rugosus throughout and is early Pliocene in age. Upper Miocene nannofossils were identified in Cores 6 to 9. Discoasters are abundant and well preserved in the Discoaster quinqueramus Zone (Cores 6 to 8) and D. neohamatus Zone (Core 9).

Coccoliths are missing in Cores 10 and 11 , except for the Catinaster calyculus Subzone in Core 10, Section 1. The gap must correspond to the upper part of the middle Miocene because in Cores 12 to 14 the Sphenolithus heteromorphus Zone was recovered. The abundance and preservation of coccoliths worsens below this gap. Assemblages of early Miocene (Helicopontosphaera ampliaperta Zone) age were recovered in Core 15 to Core 16. The specimens are abundant and moderately well preserved. The abundance (few-common) and preservation (poormoderate) are best in Core 15 and worst (few and poor) in Core 16. Dissolution increases rapidly downward in this interval. Coccoliths are missing in Sample 17, CC probably because of dissolution. The poor assemblage in Core 17 was identified as lower Miocene because Sphenolithus heteromorphus and typical Oligocene species are absent. A monotonous series, almost barren of fossils, occurs from Sample 17, CC to Core 58. Specimens of Discoaster lodoensis, a species relatively resistant to dissolution, were observed in Sample 28, CC. All the specimens present show a high degree of dissolution. The occurrence of $D$. lodoensis and Coccolithus crassus in Core 28, Section 1 helps to identify the lower Eocene Discoaster lodoensis Zone. In Core 39 one specimen of Discoaster sp. was found. This specimen is in a high stage of dissolution and may be reworked or may be a contaminant from shallower levels at this site. If it is not reworked and not a contaminant, then this sample is not older than the upper part of the middle Paleocene. Mixed assemblages of Cretaceous and Tertiary coccoliths with bad preservation were found in some core catcher samples from this monotonous series. These sparse assemblages are undoubtedly contamination from drilling.

\section{Mesozoic}

The third stratigraphic interval found is the Cretaceous. A diabase in Core 61 divides the Cretaceous sediment into two parts. Cores 59 to 60 and Cores 62 and 63 contain very rare and poorly preserved Cretaceous coccoliths. In the upper part (Core 59, top, to Core 63, Section 3, 40-43 cm) Parhabdolithus asper and Gartnerago obliquus were identified, which assigned this part to the late Cenomanian to late Turonian. In Core 60 only Watznaueria barnesae (Late Jurassic to Maestrichtian) was found.

The assemblage of Cretaceous coccoliths in Core 63, Section 4, 70-71 cm to Sample 63, CC, belongs to the late Albian to Cenomanian. The age of this assemblage is estimated as Albian to Turonian based on the presence of Lithastrinus floralis, Watznaueria barnesae, Bronsonia lata, Eiffelithus turriseiffeli, Prediscosphaera cretacea, Manivitella pemmatoidea, Zygodiscus diplogrammus, Chiastozygus litterarius, and Cribrosphaerella ehrenbergi.

\section{Radiolarians}

Significant quantities of radiolarians were identified within three stratigraphic intervals cored at Site 368: the upper Pleistocene, the middle Miocene, and the lower Eocene. Scattered fragments of radiolarians, many of which had been replaced by pyrite, were observed within the sparsely fossiliferous clay and shale below Core 30 which are of early Paleogene and Cretaceous age. These fragments were not present in sufficient abundance nor were they sufficiently well preserved to be of stratigraphic value for age determination.

\section{Cenozoic}

Cores 1 and 2 contain radiolarians diagnostic of the Pleistocene, together with rare reworked taxa of middle Tertiary age. The base of the Pleistocene was not identified because the underlying cores ( 3 through 12 ) were barren of radiolarians. Therefore, Cores 1 and 2 
may be of upper Pleistocene age. Diagnostic taxa in these two cores include: Axoprunum angelinum, Eucyrtidium calvertense, Lamprocyrtis hannai, Lamprocyclas maritalis maritalis, L. maritalis polypora, L. haysi, Pterocanium trilobum, and Ommatartus tetrathalamus. Reworked Tertiary species include Calocycletta virginis, Stichocorys peregrina, and Calocycletta costata. The low abundance of radiolarians in these two cores is partly due to dilution by a significant quantity of detrital mineral grains which occurs within the coarse fraction $(>62 \mu \mathrm{m})$. Radiolarians of middle Miocene age were identified within Cores 13 through 16. Abundances of radiolarians in these cores range from rare to common and preservation ranges from moderate to good. Core 13 through Core 15 , Section 3 are assigned to the Calocycletta costata Zone. The base of Core 15 may be assigned to the Stichocorys wolffii Zone (upper part), and Core 16 belongs to the lower Stichocorys wolffii Zone. Radiolarian disappear abruptly below Core 16 . No indication of reworking is present in any of the middle Miocene radiolarian assemblages in these four cores.

Cores 27 through 30 contain rare, moderately preserved radiolarians of lower Eocene age. Radiolarian assemblages in all four of these cores can be assigned to the Phormocyrtis striata striata Zone with a fair degree of confidence. Taxa are present whose stratigraphic ranges are consistent with this age assignment. Theocampe mongolfieri s. s. was not observed in any of the assemblages, although a few specimens which might be interpreted as the immediately ancestral form were found. All species identified in these four samples have overlapping stratigraphic ranges; consequently, there is no evidence indicating reworking of older components.

The porcellanite in Cores 32 through 35 were prepared and examined by $\mathrm{H}$. Foreman and yielded the zonal determinations shown in Table 7.

\section{Mesozoic}

Samples were prepared and examined from each core between Core 30 and the diabase sill of Core 60 . Relatively large quantities $\left(>50 \mathrm{~cm}^{3}\right)$ of material were sieved in an attempt to concentrate radiolarian debris and other coarse $(>62 \mu \mathrm{m})$ components. In general, these attempts proved to be futile for extracting usable quantities of radiolarians. The sparse, poorly preserved fauna of Cores 32 and 33 may only questionably be assigned to the Phormocyrtis striata striata Zone. Cores 34 to 36 are within the Buryella clinata Zone and Cores

TABLE 7

Radiolarian Zones, Abundance, and Preservation Determined From Samples of Chert From Site 368

\begin{tabular}{|c|c|c|c|}
\hline $\begin{array}{c}\text { Sample } \\
\text { (Interval in } \mathrm{cm} \text { ) }\end{array}$ & Abundance & Preservation & Zone \\
\hline $32-5,127-129$ & $\mathrm{R}$ & $\mathrm{M}$ & Buryella clinata Zone \\
\hline $33-2,24-25$ & C & M & Buryella clinata Zone \\
\hline $34-1,49-51$ & $\mathrm{~F}$ & M-G & $\begin{array}{l}\text { Buryella clinata/Bekoma } \\
\text { bidartensis Zone }\end{array}$ \\
\hline $34-3,94-96$ & $\mathrm{~F}$ & $\mathrm{P}$ & $\begin{array}{l}\text { Buryella clinata/Bekoma } \\
\text { bidartensis Zone }\end{array}$ \\
\hline $35-1,148-150$ & $\mathrm{~F}$ & $\mathbf{P}$ & $\begin{array}{l}\text { Buryella clinata/Bekoma } \\
\text { bidartensis Zone }\end{array}$ \\
\hline
\end{tabular}

37 to 39 represent the Buryella clinata/Bekoma bidartensis Zone. The faunas from Cores 40 to 43 are from the Bekoma bidartensis Zone and those of Core 44 probably belong to the unzoned interval in the late Paleocene. Scattered pyritized fragments are present in a few cores, but none could be identified as to genus or species. Two specimens of Dictyomitra sp. cf. D. multicostata were observed in Sample 53, CC, suggesting an Upper Cretaceous age. A porcellanite sample, Core 55, Section 2, 8-10 cm, yielded common, poorly preserved radiolarians of Campanian to Coniacian (probably Campanian) age. No other identifiable radiolarians were observed within the Cretaceous section at this site.

The radiolarian biostratigraphy at Site 368 is, in many respects, comparable to that obtained at DSDP Sites 139, 140, and 141 of Leg 14, all of which are within the general vicinity of the Cape Verde Rise. However, close comparisons are not possible because of the relatively incomplete coring at the Leg 14 sites. In general, radiolarian accumulation at these four sites was significant only within relatively short stratigraphic intervals of the Eocene, the middle Miocene, and the late Pleistocene (late Pliocene [?] at Site 139). Much of the Cenozoic is characterized by either insignificant supply of biogenous silica, or post-depositional dissolution or diagensis. The relative absence of siliceous microfossils, porcellanites, and cherts within long stratigraphic intervals at Site 368 suggests that rates of supply of biogenous silica may have been very low during long intervals of time. Calcareous microfossils are also missing from much of the Paleogene and Cretaceous section, suggesting either relatively low contributions of all microfossil groups and low primary productivity during long periods of time, or postdepositional diagenesis of both the carbonate and the silica. The character of the sparse calcareous material suggests that chemical dissolution or diagenesis has played a major role in the relative absence of carbonate in the pre-Neogene sediments at Site 368.

\section{Conclusions}

The following tentative interpretations can be drawn from the biostratigraphic data at Site 368:

1) The black shales are characterized by low abundances of poorly preserved agglutinated benthic foraminifers, scarce occurrences of planktonic foraminifers and nannofossils, and common fish debris. These characteristics may be indicative of deposition in a relatively deep basin, below the CCD. Extensive burrowing in the black shales suggest an active benthic fauna and sufficiently oxygenated conditions to maintain such activity.

2) Planktonic foraminifers in the Albian to Turonian black shales are quite small, suggesting special environmental conditions in the surface waters.

3) The absence of calcareous microfossils within much of the Late Cretaceous to early Miocene can be explained either as the result of low primary productivity through much of this time interval, or by chemical dissolution of the carbonate at the sea-floor interface or post-depositionally. 
4) The absence of siliceous microfossils within much of the Late Cretaceous to early Miocene can perhaps be explained by remobilization of silica into chert; the absence of both siliceous microfossils and cherts elsewhere in this section may be the result of low primary production.

5) The good preservation of calcareous microfossils in the upper Miocene and Holocene sediments suggests either a deepening of the CCD, or an uplift of the Cape Verde Rise above the existing CCD.

\section{ACCUMULATION RATES}

The accumulation rates for Site 368 (Figure 8) were calculated using the biostratigraphic record and estimations of absolute time intervals (see Sites 366 and 367). No attempt has been made to correct the sediment thickness for the effects of compaction. The data allow calculation of rates within relatively narrow limits only for the Holocene to middle Miocene. There is a general decrease in the rates of sediment accumulation downward: Pleistocene (ca. $30 \mathrm{~m} / \mathrm{m} . \mathrm{y}$.), Pliocene-upper Miocene (about $20 \mathrm{~m} / \mathrm{m} . \mathrm{y}$. ), middle and lower Miocene (ca. $10 \mathrm{~m} / \mathrm{m} . \mathrm{y}$.).

There is a reduced mean accumulation rate of about $2 \mathrm{~m} / \mathrm{m}$.y., if no hiatuses are present between the lower Miocene (core 18) and middle Eocene (Core 23).

The average accumulation rates within the dated middle to lower Eocene (Cores 27 to 30) cannot be lower than $11 \mathrm{~m} / \mathrm{m} . y$. A projection downward with the same minimum value fits nearly the whole stratigraphic range of Unit 2, if the questionable dating of Core 39 is neglected. Otherwise, accumulation rates of about 20 $\mathrm{m} / \mathrm{m} . \mathrm{y}$. are calculated for the upper part of the early Paleogene section, and very low accumulation rates in the lower part, probably consistent with the occurrence of brownish shales (Zone $2 \mathrm{~b}$ ).

The basal parts of Unit 2 (2c) and Unit 3 are also poorly dated, so that the minimum mean values of ca. $10 \mathrm{~m} / \mathrm{m} . \mathrm{y}$., assuming no gaps, are of very low significance.

\section{CORRELATION OF SEISMIC REFLECTION PROFILES WITH DRILLING RESULTS}

Seismic-reflection profiles recorded while approaching the site (see Figure 9) show that the acoustic section consists mainly of a series of nearly horizontal parallel reflectors. The upper part of the section from the sea floor to about $0.26 \mathrm{sec}$ below the bottom shows only rare, faint, parallel reflectors. The section below that level is characterized by an abundance of finely layered parallel reflectors. The upper boundary of this zone is quite sharp whereas the lower one is diffuse. It consists merely of a gradual decrease in the density of the reflective layers, particularly noticeable below about $0.6 \mathrm{sec}$. A badly defined reflector can be observed around $0.73 \mathrm{sec}$. The rest of the section is moderately stratified until a sharp and strong reflector is encountered at $1.02 \mathrm{sec}$. This reflector appears discontinuous, particularly on the Meteor 25/1971 profile and on the Glomar Challenger profile recorded while leaving the site (see Figure 3). Below that reflector some faint horizons are still visible, especially in the areas where the strong reflector

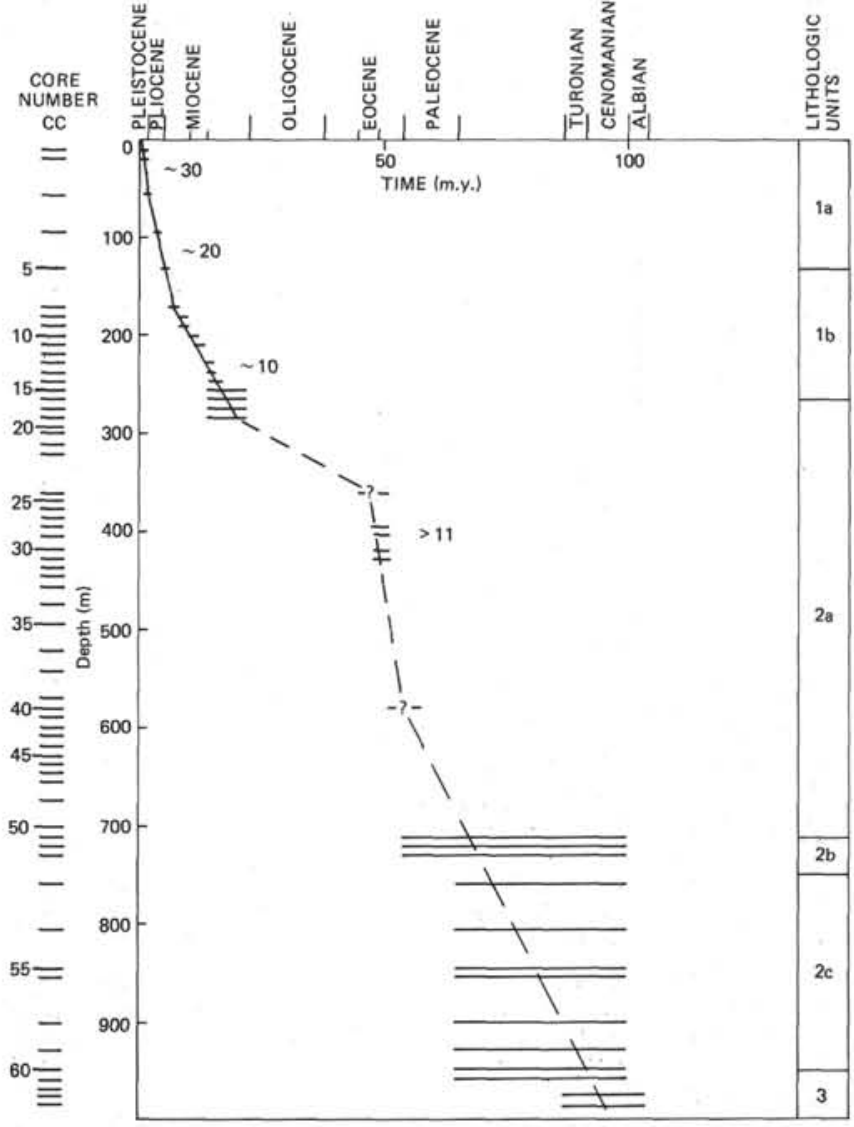

Figure 8. Plot of average accumulation rates for Site 368 .

disappears. No reflector is observed below about 1.4 to $1.5 \mathrm{sec}$.

The top of the finely layered zone correlates well with an abrupt change in lithology observed at 202 meters below the sea floor. That level marks the base of the lower to middle Miocene carbonate ooze and marl section and the top of a predominantly terrigenous interval in which turbidites are abundant throughout. Such a correlation yields an interval velocity of 1.55 $\mathrm{km} / \mathrm{sec}$ for the uppermost interval. Although no detailed correlation can be established between the thin acoustic units and specific lithological variation; the fine layering visible on the profile is characteristic of sediment accumulations rich in turbidites. The top of an interval rich in chert encountered at about 350 meters within the sediment section does not produce any significant reflector at the site because such a reflector would be masked by the layered interval. It is possible, however, that the top of the chert-rich horizon could correlate with a barely visible reflector observed on the seismic profile about 16 to $25 \mathrm{~km}$ before reaching the site.

The faint reflector at about $0.73 \mathrm{sec}$ correlates tentatively with a silt-rich horizon recorded at 636 meters subbottom. Such a correlation would bring the average interval velocity for the overlying interval to $1.84 \mathrm{~km} / \mathrm{sec}$, which appears reasonable considering the chert content of the sediment.

The strong lower reflector at $1.02 \mathrm{sec}$ correlates well with the larger diabase sill observed at about 960 


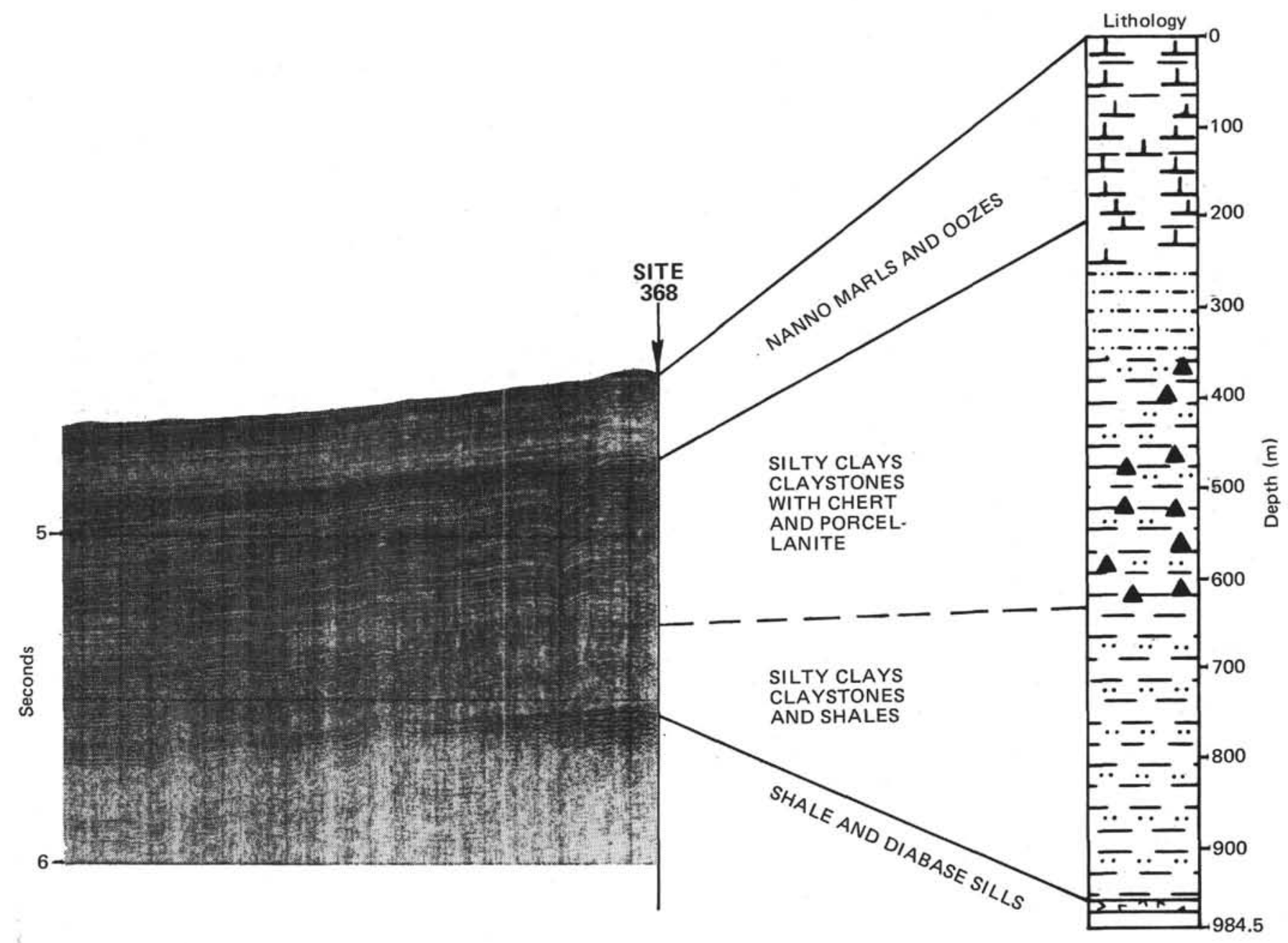

Figure 9. Correlation of seismic-reflection profile with drilling results at Site 368.

meters. The resulting average interval velocity for the entire overlying section is $1.88 \mathrm{~km} / \mathrm{sec}$.

\section{SUMMARY AND CONCLUSIONS}

Site 368 was drilled on the southwestern flank of the Cape Verde Rise northeast of the Cape Verde Islands. The Cape Verde Islands area is undoubtedly underlain by oceanic crust because this volcanic massif lies in an area of rather well-defined Mesozoic magnetic anamalies (Hayes and Rabinowitz, 1975). This rise has been tentatively interpreted by Seibold and Hinz (1974) as resulting from a very young uplift. Site 368 is located just on the seaward side of that boundary (Figure 1). The sedimentary section can be summarized as follows from top to bottom: Quaternary to late early Miocene or early middle Miocene marl and nannofossil ooze; early Miocene to ?Upper Cretaceous clay and claystone (turbidites) with occasional chert and porcellanite; Turonian-Albian black shale interbedded with diabase sills (see Figure 12).

\section{Most Significant Results}

Data obtained at this site strongly suggest that the Cape Verde Rise is a result of a broad uplift of more than 1000 meters, probably related to and con- temporaneous with the early Neogene volcanic activity that built the Cape Verde Islands and is also recorded in the region of Dakar. This volcano-tectonic origin of the rise is supported by three different observations:

1) Absence of carbonates between the TuronianAlbian and the middle Miocene,

2) Occurrence of a series of turbidites in most of the terrigenous section, 3) Presence of diabase sills at the base of the section, indicative of volcanic activity beneath the rise after the emplacement of the oceanic basement.

\section{Absence of Carbonates in Most of the Pre-middle Miocene Section}

Most of the section was expected to be rich in carbonates because of the relatively shallow depth of the rise. The fact that it was found almost devoid of calcareous microfossils was a first indication that depth of deposition of the sediments might have undergone major changes.

There are three different ways to explain the absence of carbonates in the sediments: lack of carbonate input; dissolution on the sea floor; or diagenetic dissolution within the sediments. A complete lack of carbonate input would be difficult to explain in an area 
that was still relatively close to the equator during most of the Late Cretaceous. The absence of radiolarians, however, suggests that fertility of the surface waters could have been relatively low. On the other hand, the relative abundance of fish debris seems to indicate that productivity in the surface waters did not drop drastically. A combination of factors should be invoked but dissolution, combined with moderate productivity of the surface waters seems to be the most probable cause for the absence of both calcareous and siliceous microfossils. Further support to this interpretation is found in the fact that only the most dissolutionresistant species of coccoliths are found in some horizons. Foraminifers also are sometimes observed in the form of casts. Dissolution of carbonate (and siliceous) biogenous particles during diagenesis is documented by the occurrence of dolomite and siderite (as well as porcellanite and chert). The overall quantities of these minerals, however, are not very large and most of the carbonate dissolution should have taken place before burial. This implies that the site was below the CCD at the time of deposition of most of the sedimentary section, at least since the Late Cretaceous, and that it was above the CCD after the middle Miocene.

It is naturally tempting to interpret this transition from non-calcareous to calcareous sediments as being the direct result of a regional uplift that brought the site above the CCD. A general drop of the CCD between the early and late Miocene, however, is observed at several sites drilled in the deep basins nearby (especially Sites 140 and 367). Unfortunately, the precise age of the transition between non-carbonate and carbonate sediments is most often not available. Therefore, it is difficult to determine what could have been the different effects of either a sudden drop of the CCD in a deep, relatively flat basin or the combination of a CCD drop with a local uplift on Cape Verde Rise. Because independent evidence for an uplift of the rise at Site 368 , as well as at Site 141 (Leg 14) on a local basaltic plug, can be observed, it appears logical to consider that the general drop of the CCD affected the basin just prior to the uplift of Cape Verde Rise. Because the passage from clay to marl at Site 368 is rather abrupt, it is possible that the uplift was almost synchronous with the CCD drop.

\section{Presence of Abundant Turbidites on the Rise}

The entire terrigenous section, from the top of Turonian-Albian black shale to the base of the nannofossil marl and ooze, is rich in turbidites. The best-developed sequences are observed in the lower two-thirds of the section where thin layers of silt and sand are abundant. The coarse-grained material decreases in abundance upward, but turbidite sequences are present there, too. The composition of the coarse fraction indicates continental sources for the turbidites and not local volcanic sources. Because of the semilithified to well-lithified state of most of the sediments, sedimentary structures are well preserved and there is no doubt about their nature. Bottom current reworking is observed only occasionally in the form of current-winnowed silt laminae and lenses. Therefore, the conclusion that these sediments were deposited near the base of the continental rise prior to the existence of Cape Verde Rise seems inescapable. The gradually decreasing abundance of coarse-grained terrigenous material in the upper part of the interval might be related to the uplift of the rise, to a change in the sources (e.g., Upper Cretaceous regressions and transgressions), or to a change in the pattern of the main channels carrying turbidite material to the lower continental rise.

\section{Relatively Recent Volcanic Activity Beneath the Rise}

Volcanic activity during the ?late Paleogene to early Neogene in the area is well documented. Most of the volcanic material present on Cape Verde Islands is of Miocene age and volcanic activity of the same age is reported around Dakar. The occurrence of volcanic ash layers in the late Miocene sediments of Site 368 is in good agreement with these data and the volcanogenic material probably results from the emergence of the Cape Verde Islands or from a peak in volcanic activity on the islands at that time. Indirect evidence is also provided by what seems to be volcanic "aprons," interbedded in the upper part of the sedimentary section (middle to upper Miocene), which are visible on the Meteor 25/1971 seismic profile (Figure 2) at about $35 \mathrm{~km}$ southwest of Site 368 . The occurrence of diabase sills near the base of the section at Site 368 brings a more direct confirmation of the presence of volcanic activity beneath the Cape Verde Rise long after the emplacement of basement, which is of probable late Jurassic age in this area. The diabase sills seem to have been preferentially injected in a zone of weakness in the sedimentary column, near the top of the black shale section, below relatively undercompacted clays. Lamont-Doherty seismic profiles (Vema 30 ) across the rise (Figure 10) and the results of drilling at Site 141 (Leg 14) show possible occurrences of intrusive volcanic material in the area. These intrusions seem to be either in the form of vertical plugs, as at Site 141, or in the form of sills, as at Site 368. The seismic profiles indicate the possible co-occurrence of these features (Figure 10) on the rise. The specific age of the beginning of the volcanic activity is not easy to determine. Some possible Paleogene marine sediments have been reported on Cape Verde Islands. None of our data show evidence of pre-Miocene volcanic activity in the area. Radiometric age determination of the diabase sills present at Site 368 confirm their Miocene age (Duncan and Jackson, this volume).

The evolution of the Cape Verde Rise can be summarized as follows (Figure 11):

1) From the late Jurassic to the early (or early Late) Cretaceous, the evolution of the basin was probably comparable to Site 367.

2) From the Late Cretaceous to the early middle Miocene, abundant terrigenous material was brought down to the basin by turbidity currents and this accumulation initiated the building of the continental rise. Most of the terrigenous material probably originated from the Senegal Basin area.

3) Uplift of Cape Verde Rise due to volcanic activity started probably around the middle Miocene while at about the same time the CCD was reaching the bottom 


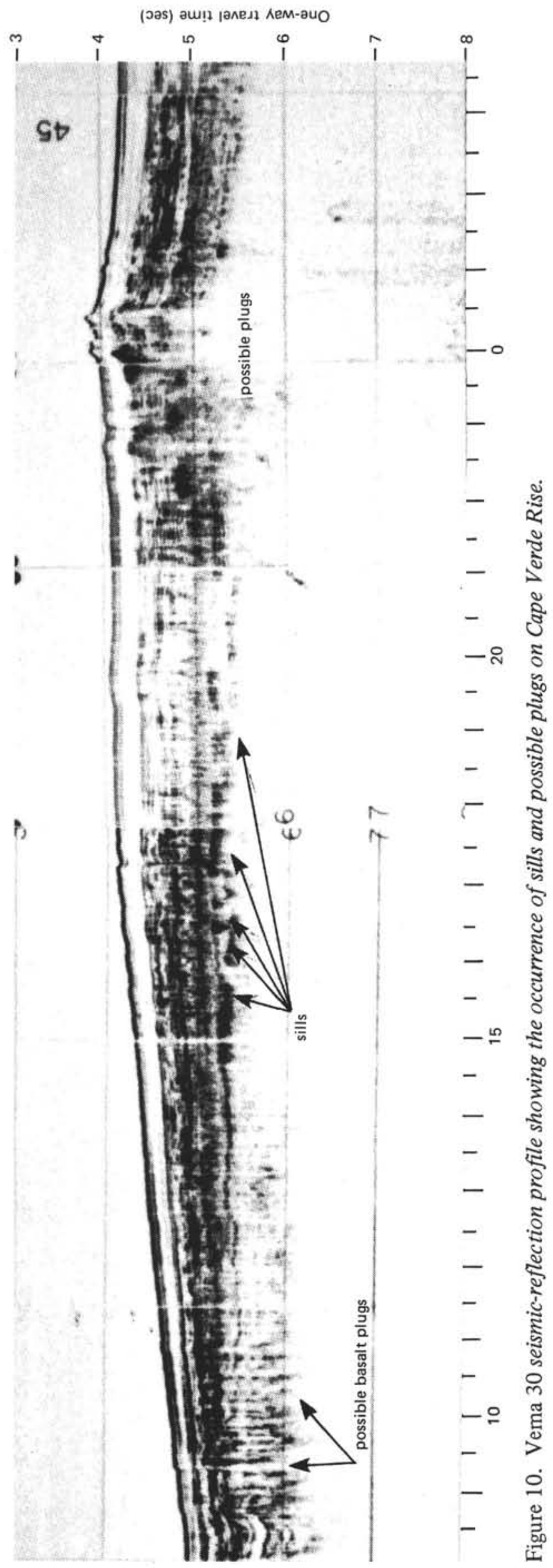

of the entire basin. Alternatively, the CCD might have dropped just before the uplift occurred. At that time no turbidites could reach the elevated area and they were deflected toward the south into the Cape Verde Basin. Then, only pelagic marl and calcareous ooze were deposited until the present time.

\section{Problems in Paleoenvironment}

As stated earlier, the predominantly terrigenous nature of the sediments from the Cape Verde Rise was unexpected. If our interpretation of the origin of the rise is correct, then all the pre-middle Miocene facies are deep-basin facies. A major consequence is that the terrigenous interval is almost completely devoid of calcareous microfossils. Because siliceous microfossils are also nearly absent, the stratigraphic control is very poor and often nonexistent. Therefore, paleoenvironmental interpretations regarding this interval remain rather speculative.

The rate of accumulation curve (see Figure 8) shows relatively high values for the Late Cretaceous and lower Tertiary. If we tentatively correlate the occurrence of chert at this site with the dated occurrence of chert at Site 367 , then it appears that the rates of accumulation were be particularly high during the middle and lower Eocene ( 20 to $30 \mathrm{~m} / \mathrm{m}$.y.). This cannot be explained by an increase in productivity because the chert is not particularly abundant and the rest of the sediment is almost completely barren. We must invoke an increase in the terrigenous output, eventually related to the regression at the Cretaceous/Tertiary boundary in the Senegal Basin. The abundance of turbidites in that part of the section lends further support to this interpretation.

Because we do not have any stratigraphic control for the interval between the middle Eocene (age based only on the youngest occurrence of chert) and the lower Miocene, it is impossible to determine if the Oligocene is missing or only reduced. We can merely point out that only about 75 meters of sediment account for the time interval between the early Miocene and the middle Eocene. This slow rate of sedimentation or hiatus contrasts with the underlying interval and might be the result of either the end of the deposition of turbidites on the rise (maybe related to the uplift) or erosion or nondeposition caused by bottom currents. Comparison with the rates of accumulation observed at Site 367 seems to favor the latter explanation because they show a decrease corresponding to the same time interval. This is somewhat puzzling because the Oligocene times could be expected to be a period of large terrigenous input in the basin because the African continent underwent a substantial uplift during that time. It seems that removal or nondeposition of sediments by bottom currents might be the only way to explain the widespread occurrence of an Oligocene-?lowermost Miocene hiatus, both in terrigenous deposits and in pelagic carbonates in the deep basins of the South and North Atlantic. Such a vigorous bottom circulation might be related to the onset of circulation of Antarctic Bottom Water caused by the separation of Antarctica/Australia and the beginning of the glaciations. 
A
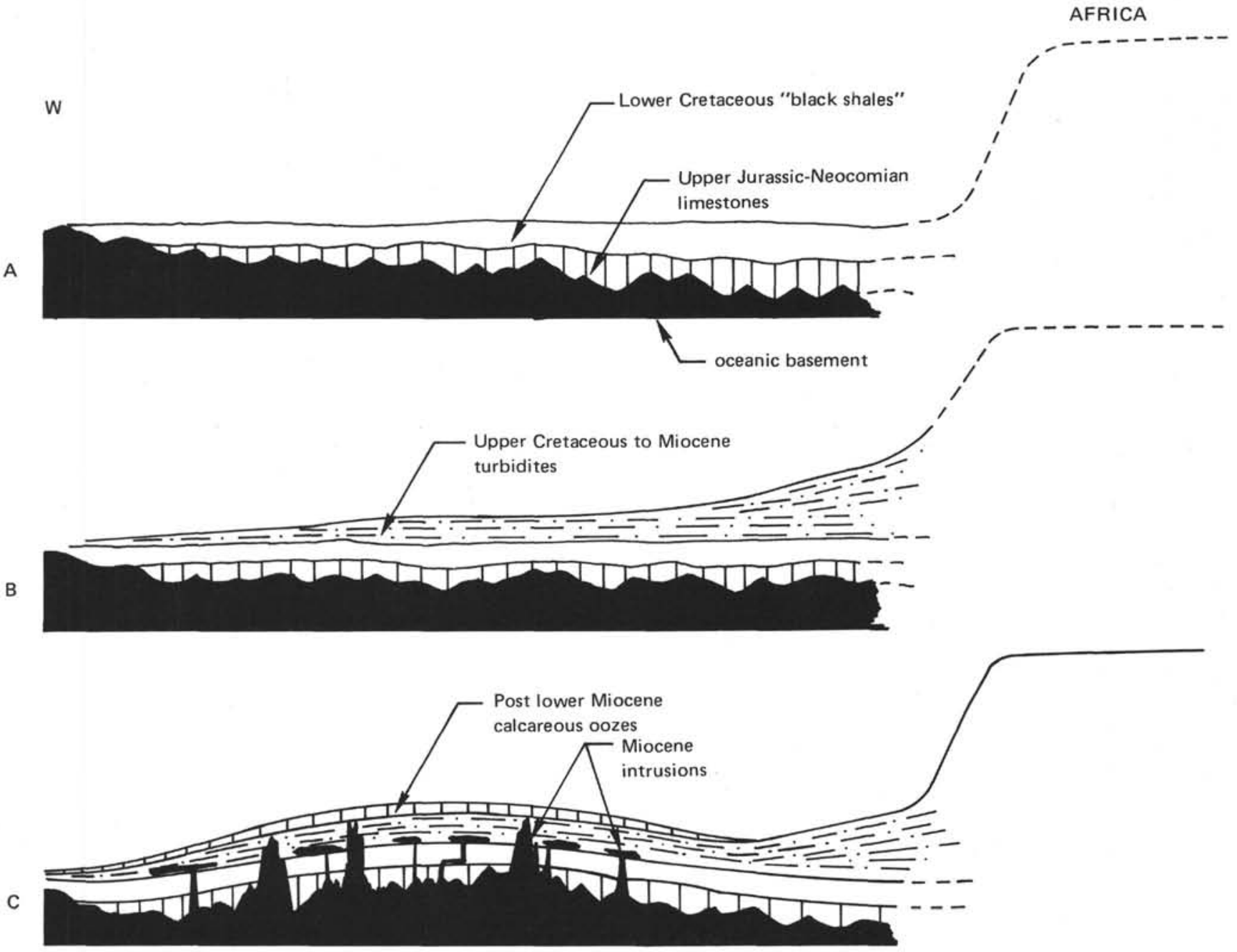

Schematic reconstruction of the evolution of Cape Verde Rise

A - Upper Cretaceous
B - Pre-Miocene
C - Post Miocene

Figure 11. Schematic reconstruction of the evolution of Cape Verde Rise.

If, however, that period should correspond with relatively abundant detrital terrigenous input from the African continent in the eastern North Atlantic, then the final place of accumulation of these sediments is still a mystery.

The transition between the terrigenous sediments and the overlying nannofossil marl during the early Miocene is rather abrupt. The terrigenous fraction, however, is still abundant up to the base of the late Miocene where it decreases rapidly. Because the rate of sedimentation doubles at that time, it appears that the decrease in abundance of terrigenous material is, in large part, caused by a net increase in the biogenic contribution to the sediment. It might also be related partly to decreasing terrigenous input in the basin caused by climatic change or transgression over the shelf area. The increase in the amount of terrigenous components observed during the Pleistocene, however, is probably the result of an increase in the net terrigenous input because of the corresponding increase in the rate of sedimentation. This Pleistocene terrigenous phase, well documented in the Atlantic basins, is directly related to the Quaternary climatic evolution as well as to the succession of eustatic transgressions and regressions on the continental shelves. Part of the terrigenous material found at Site 368 could also be of aeolian origin.

\section{The Diabase Sills and Their Local Influence on} Diagenesis in the Sediments

The diabase sills were found near the upper boundary of the Turonian-Albian black shale facies. The preferential intrusion of sills at this particular level is inferred from examination of the seismic profiles. The analysis of physical properties of the sediments shows that the terrigenous interval, and especially the zones where abundant turbidites are observed, appears undercompacted. It is thus possible that the relatively sharp contrast between the black shale and the lowest zone of turbidites represents a zone of weakness in the 
sedimentary column, favoring the intercalation of sills at that level.

Three sills were encountered, two of them very thin $(10$ to $20 \mathrm{~cm})$ and one thicker $(12.5 \mathrm{~m})$. The thin ones are fine grained and have the texture and composition of tholeiitic basalts. The upper and lower margins $(\approx 20$ $\mathrm{cm}$ ) of the thick sill are fine grained and identical to the overlying thin ones. The rest of the sill is coarse grained and exhibits olivine-gabbro texture and composition. The contact between the thick sill and the sediment is extremely sharp, with no brecciation or inclusion of sediments within the diabase. Thermal alteration of the sediments is clearly visible over about $20 \mathrm{~cm}$ in the overlying sediments and about $90 \mathrm{~cm}$ in the sediments immediately below the sill.

One particular aspect of the diagenetic effect of the sill on the black shale is the possible "distillation" of the organic matter under the influence of local heating and the generation of hydrocarbons. This warrants further shore-based analysis. Local concentrations of light hydrocarbons that were not present anywhere else in the black shale have been found in the immediate vicinity of the sill.

\section{Significance of the Seismic Reflectors}

The finely layered zone of reflectors observed on the seismic profiles recorded over the Cape Verde Rise could not be correlated directly with the transition from terrigenous to calcareous sediments. Because turbidites are observed throughout the layered interval, it seems reasonable to interpret the acoustic characteristics of this interval as the results of turbidite deposition. Such an interpretation becomes more reasonable if we imagine the configuration of the rise prior to uplift. In such a restoration, the profile would display thin, parallel, horizontal layering, comparable to the records obtained in areas of thick turbidite accumulations.

Reflector D, correlates with the major diabase sill. This explains the discontinuous aspect of this reflector. The proximity of this reflector to the top of the black shale unit is worth noticing. It implies that possibly the implacement of the diabase sill was associated with a change in physical properties in the sediment near the top of the black shales. Such a change could be responsible for the presence of the reflector tentatively identified as $A^{*}$ at Site 367 (instead of Horizon $\beta$ as previously envisaged).

\section{REFERENCES}

Diester-Haas, C., 1976. Late Quaternary climatic variations in northwest Africa deduced from East Atlantic sediment cores: Quat. Res., v. 6, p. 299-314.

Gardner, J.V., 1975. Late Pleistocene carbonate dissolution cycles in the eastern equatorial Atlantic. In Sliter, W., Berger, W., and Be, A. (Eds.), Dissolution of deep-sea carbonates: Cushman Found. Foram. Res. Spec. Publ. 13, p. $120-141$.

Hayes, D.E. and Rabinowitz, P.D., 1975. Mesozoic magnetic lineations and the magnetic quiet zone off northwest Africa: Earth Planet. Sci. Lett., v. 28, p. 105-115.

Jacobi, R. and Hayes, D.E., in preparation. Bathymetry and microphysiography of the continental margin off northwest Africa.

Pflaumann, U., 1975. Late Quaternary stratigraphy based on planktonic foraminifera off Senegal: Meteor Forsch.Ergelanisse, Ser. C., no. 23, p. 1-46.

Seibold, E. and Hinz, K., 1974. Continental slope construction and destruction, West Africa. In Burk, C.A. and Drake, C.L. (Eds.), The geology of continental margins: New York, (Springer-Verlag), p. 179-196. 


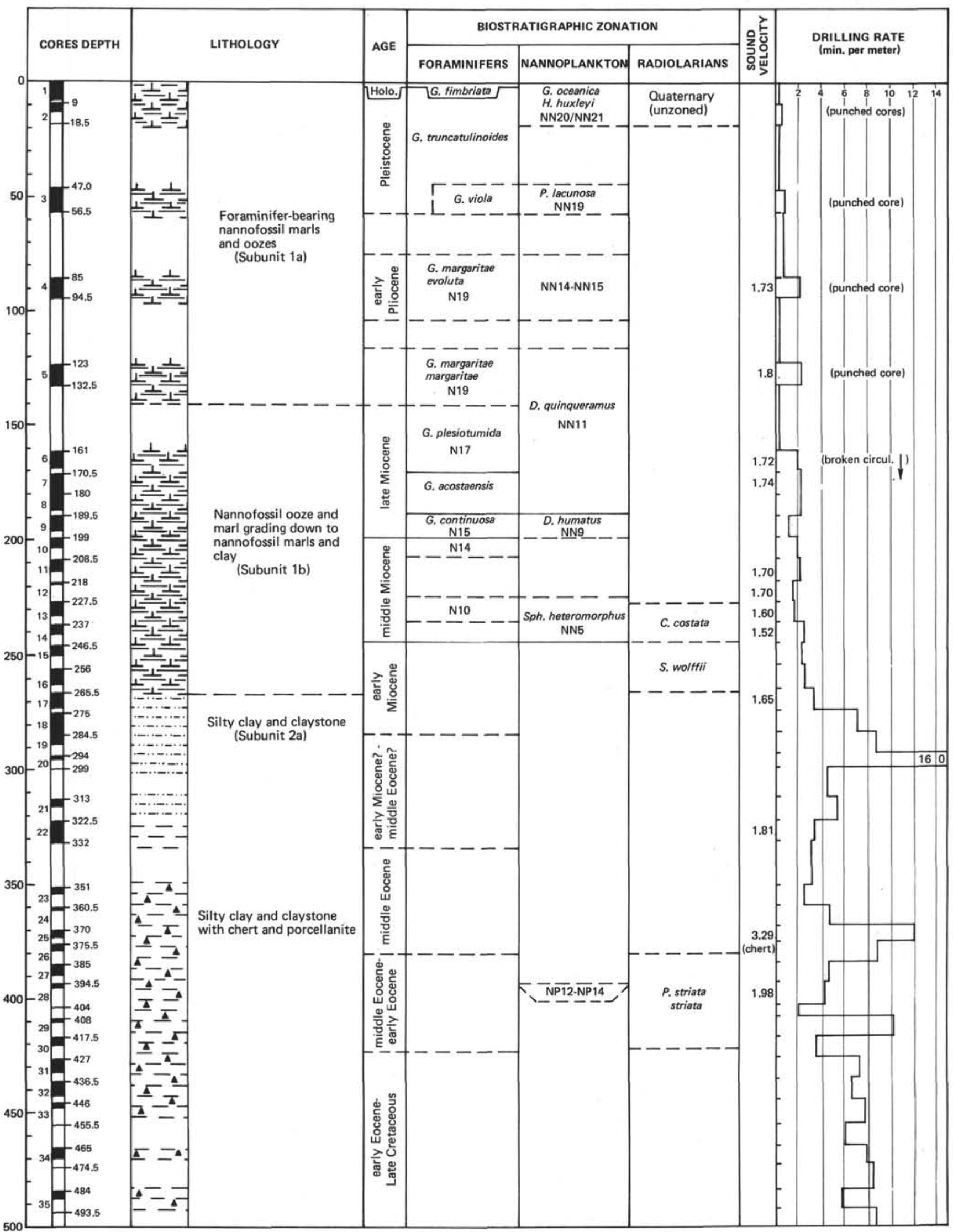

Figure 12. Graphic summary of lithology, age, biostratigraphy, sonic velocity, and drilling rate for Site 368. 


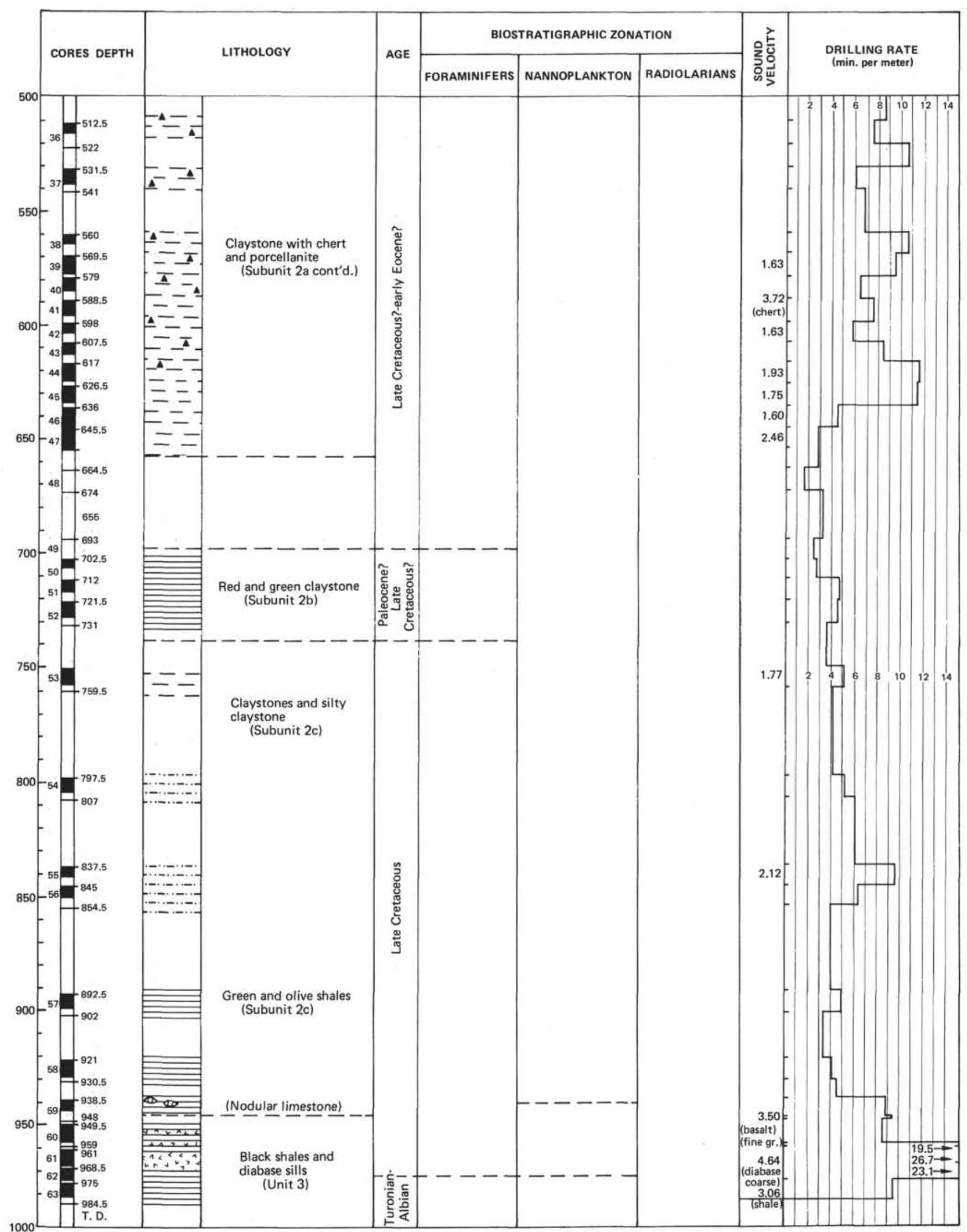

Figure 12. (Continued). 


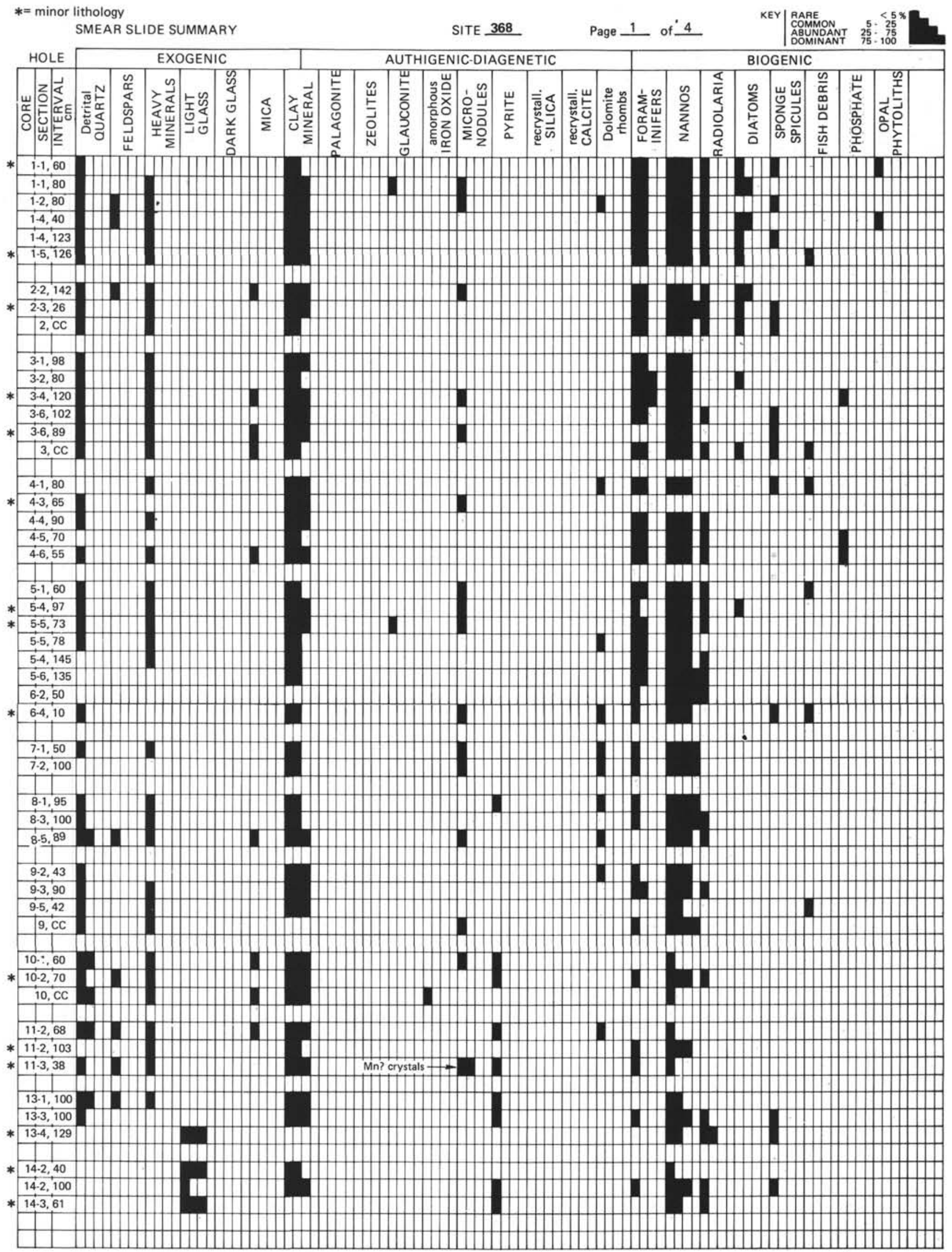




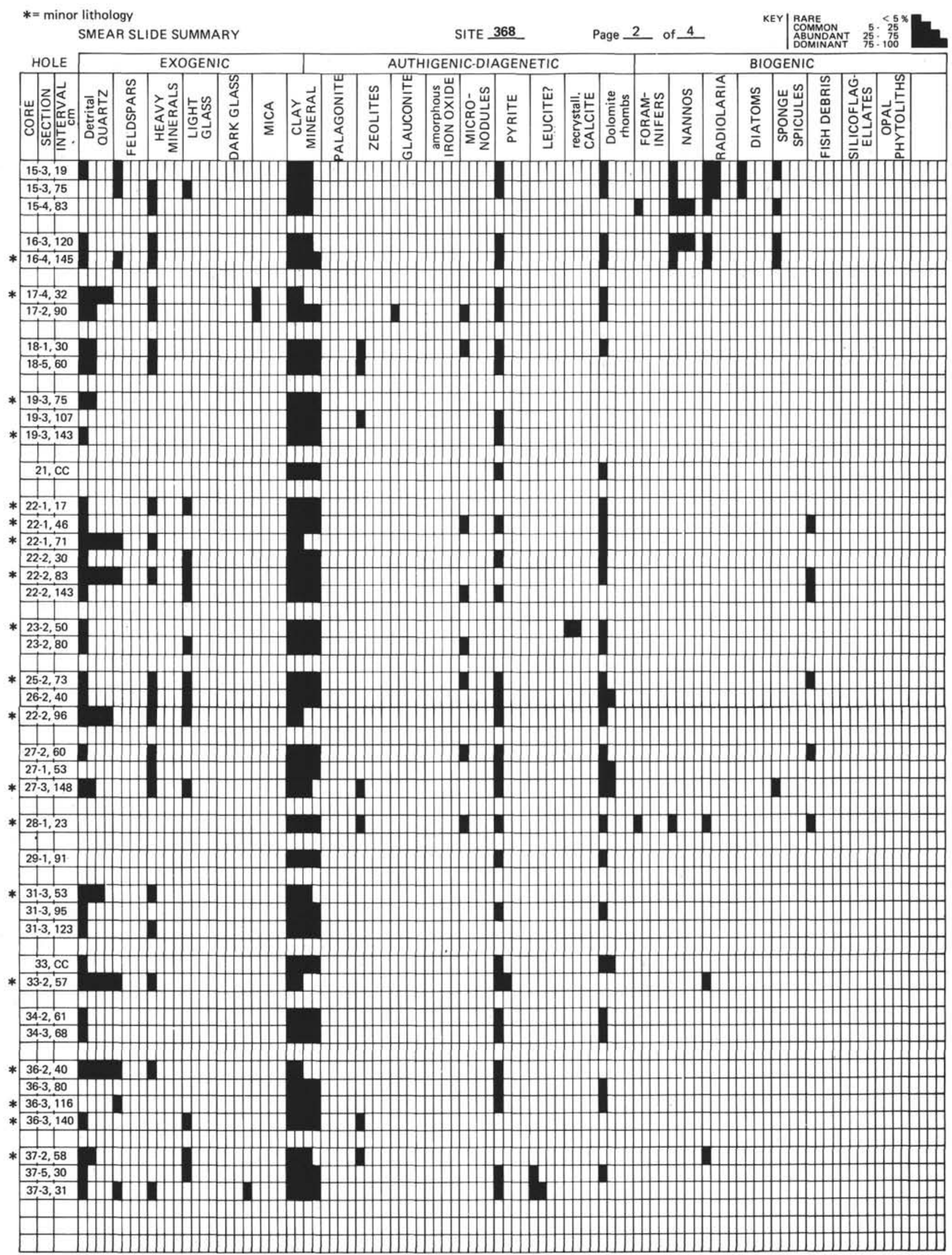


*= minor lithology

SMEAR SLIDE SUMMARY

SITE 368 Page 3 of 4

KEY $\mid \begin{aligned} & \text { RARE } \\ & \text { COMMON }\end{aligned}$

$\begin{array}{ll}\text { COMMON } & 5.25 \\ \text { ABUNDANT } & 25.75 \\ \text { DOMINANT } & 75: 100\end{array}$

\begin{tabular}{|c|c|c|c|c|c|c|c|c|}
\hline HOLE & \multicolumn{7}{|c|}{ EXOGENIC } & \\
\hline 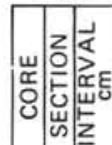 & 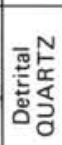 & 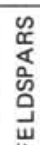 & 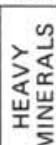 & 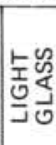 & 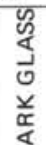 & $\frac{\mathbb{J}}{\Sigma}$ & 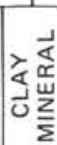 & \\
\hline
\end{tabular}

AUTHIGENIC-DIAGENETIC

BIOGENIC

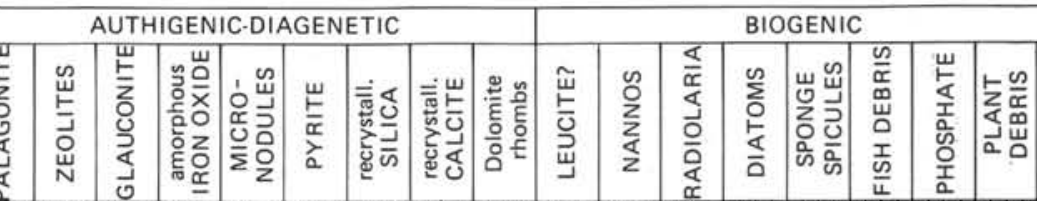

* $39 \cdot 2,110$

* $39-2,114$

* $40-2,123$

40.4, 100

$40-4,105$

* $40-4,140$

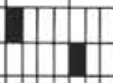

$\Sigma$

1||||||||
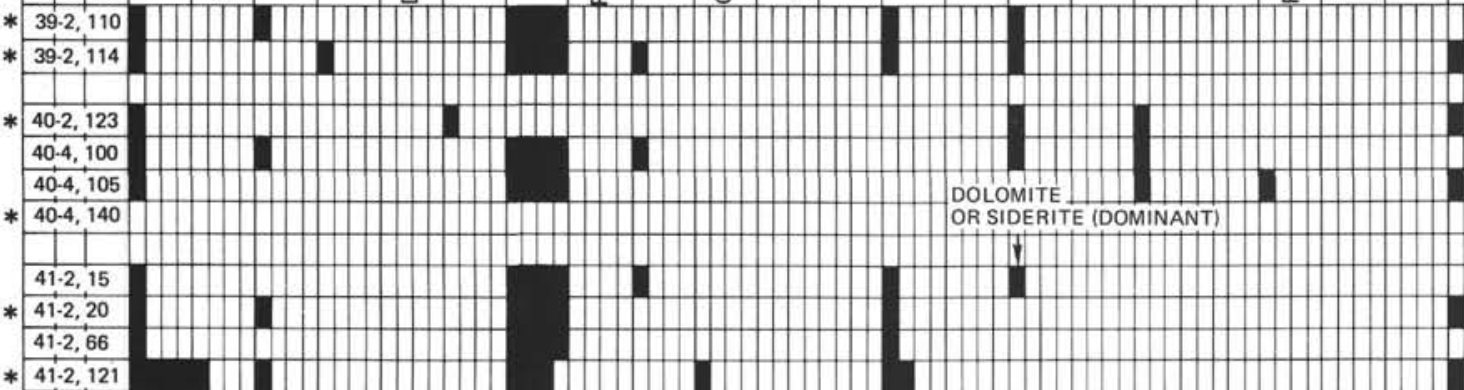

* $41 \cdot 2,12$

* $42-2,92$

$42 \cdot 2,88$

* 43-3,91

* 44-1,86

* $44 \cdot 3,5$

44.6, 30

* 44.6, 46

* 44.6, 115

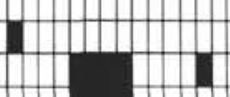

\begin{tabular}{l|l|}
\hline & \\
\hline &
\end{tabular}

* 45-2,63

\begin{tabular}{|l|l|}
\hline $45-2,110$ \\
\hline $45-4,50$ \\
\hline $45-4,58$
\end{tabular}

$\frac{45-4,50}{45-4,58}$

$45,4,58$

* $\frac{1}{47-2,62}$

* $47.2,91$

$47-6,85$

\begin{tabular}{|l|}
\hline 11 \\
\hline $50-3,60$ \\
\hline $50-3,76$
\end{tabular}

\begin{tabular}{|l|}
$50-3,76$ \\
\hline $50-3,76$
\end{tabular}

* 50-3,116

$50, \mathrm{CC}$
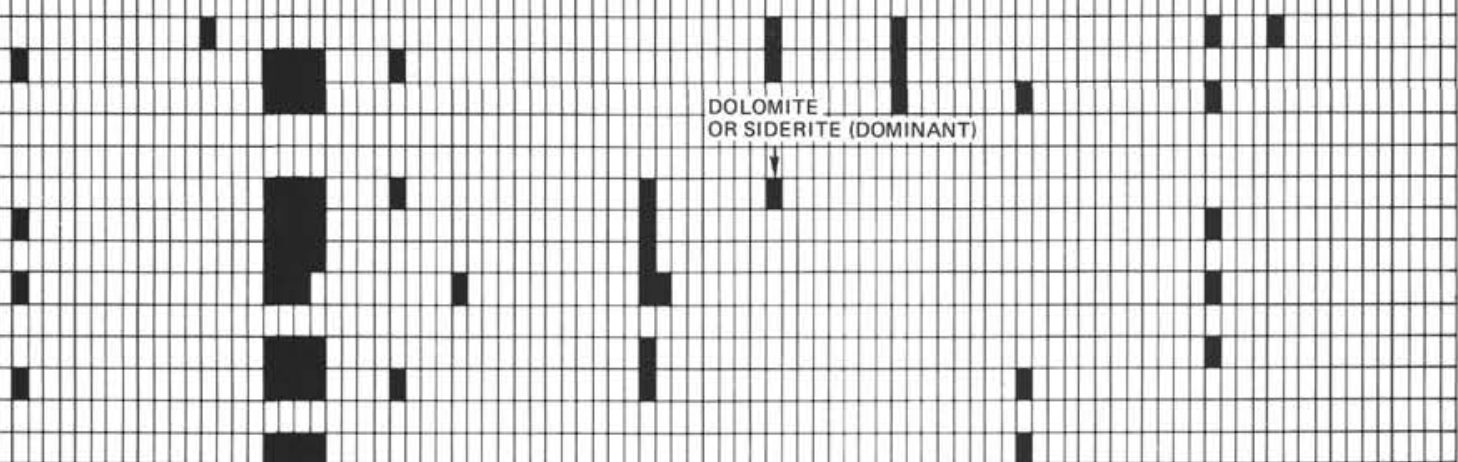

:
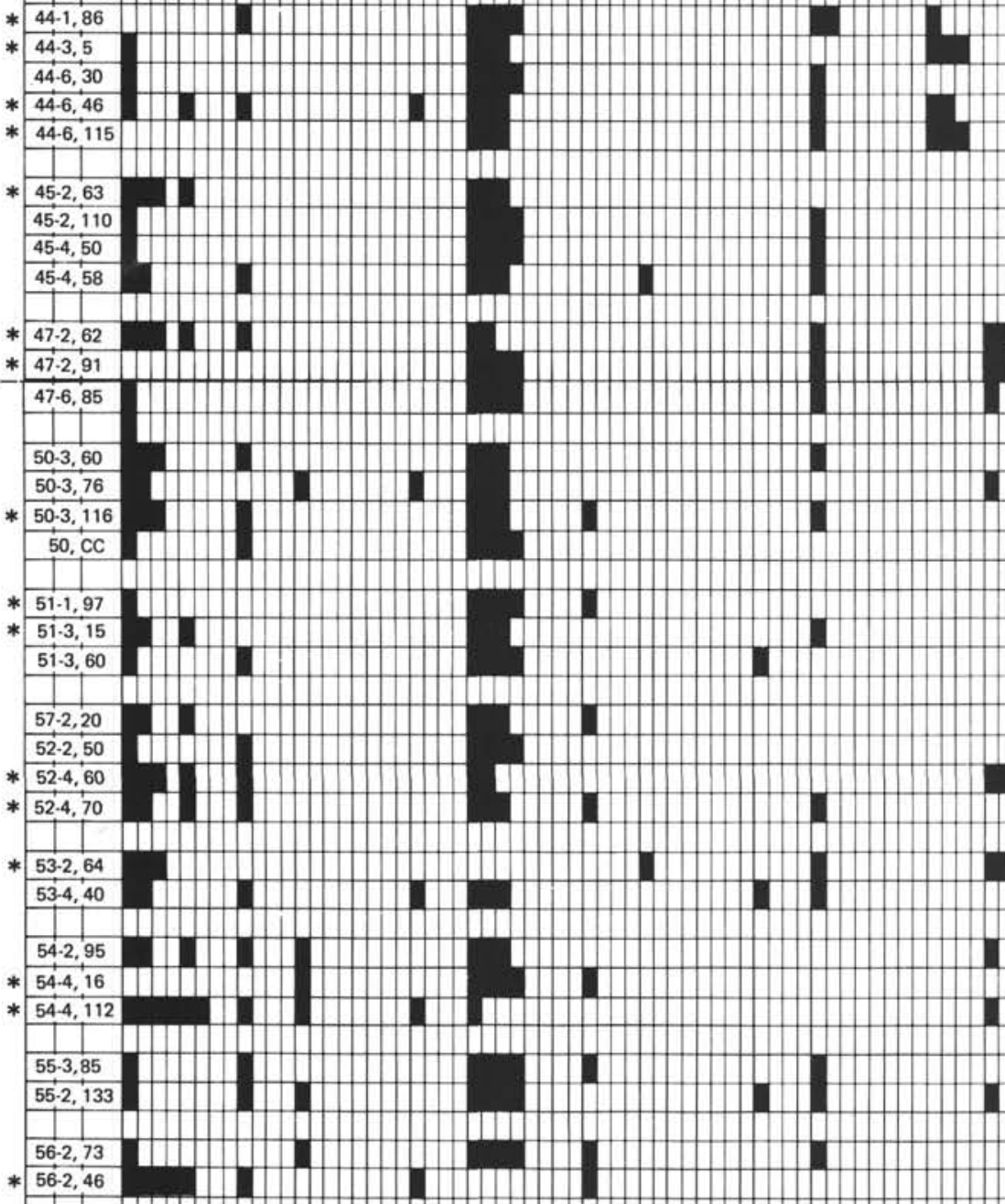
SITE 368: CAPE VERDE RISE

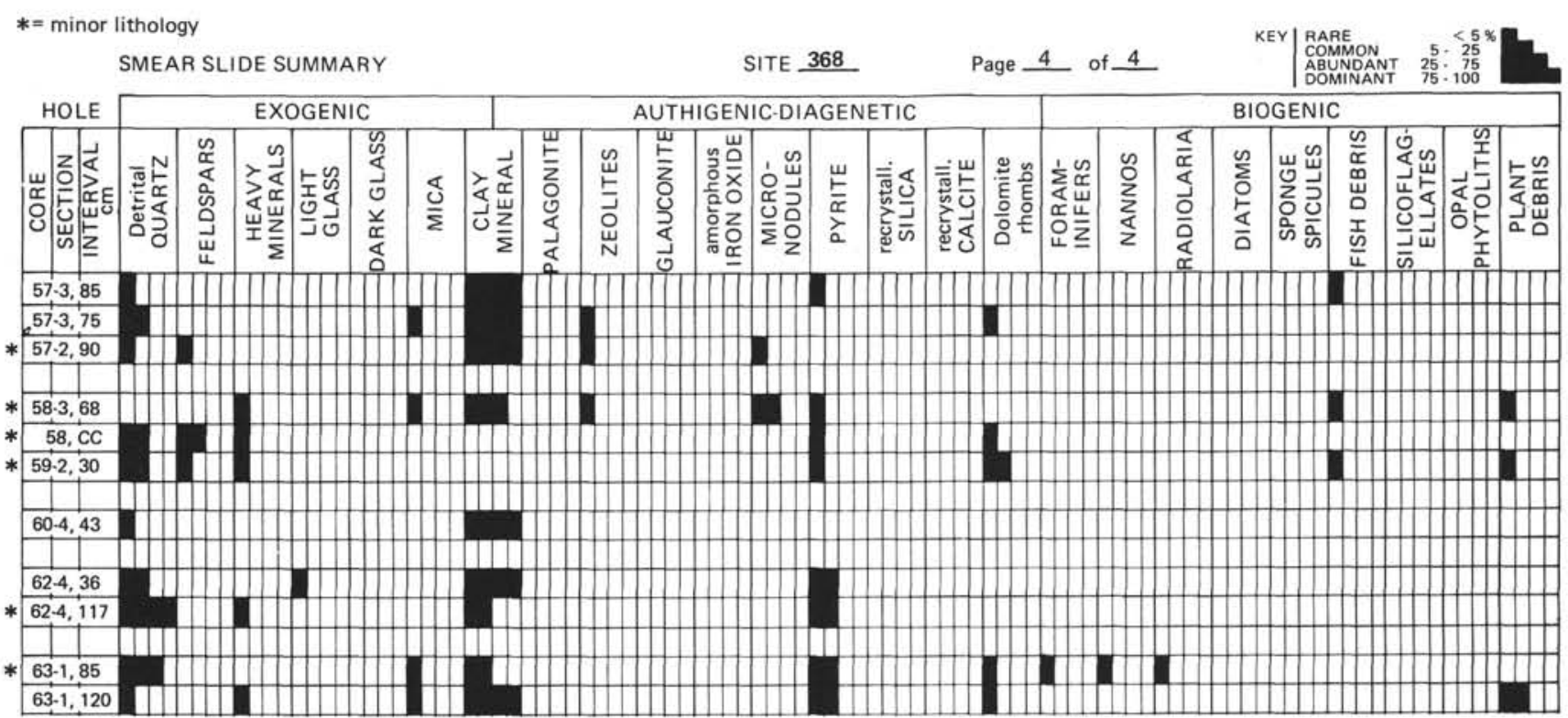




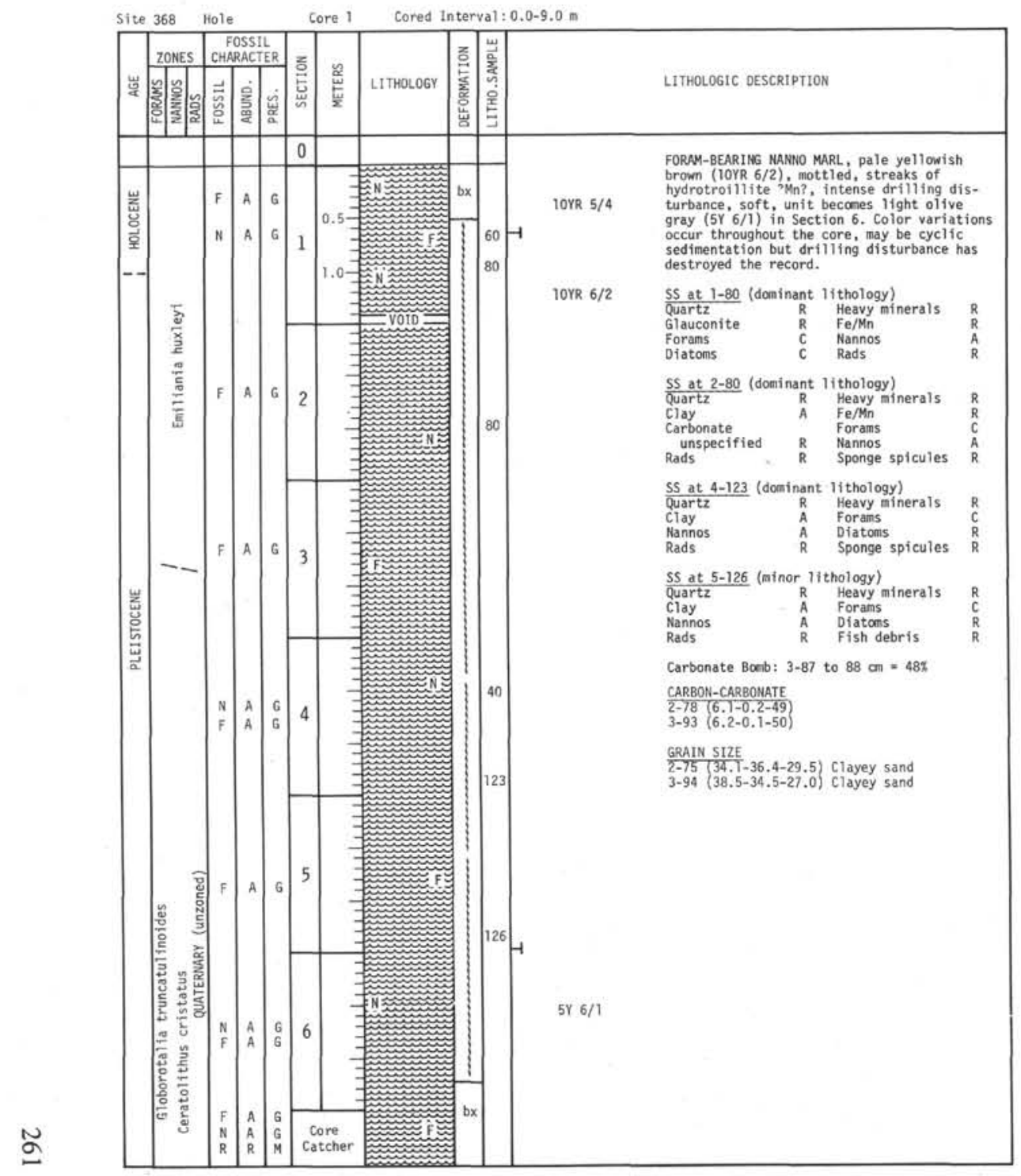

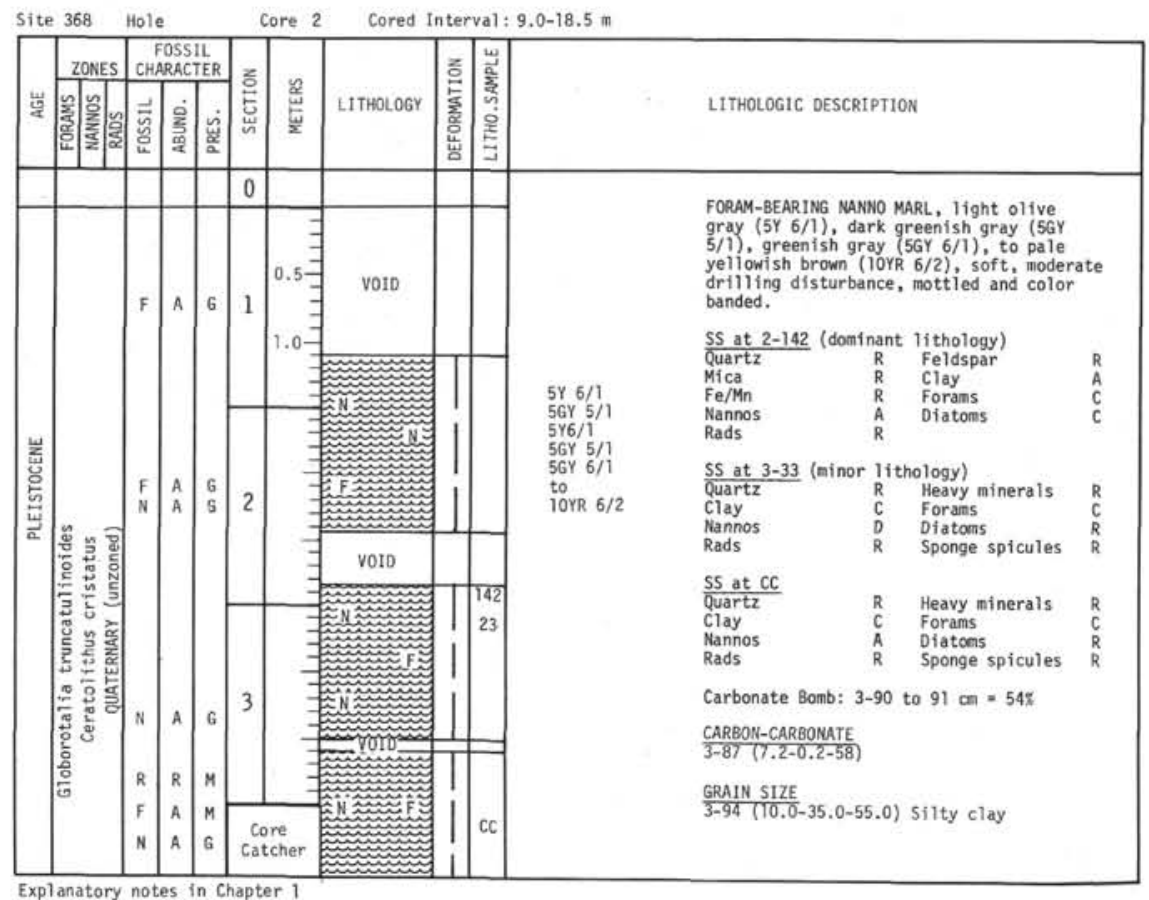



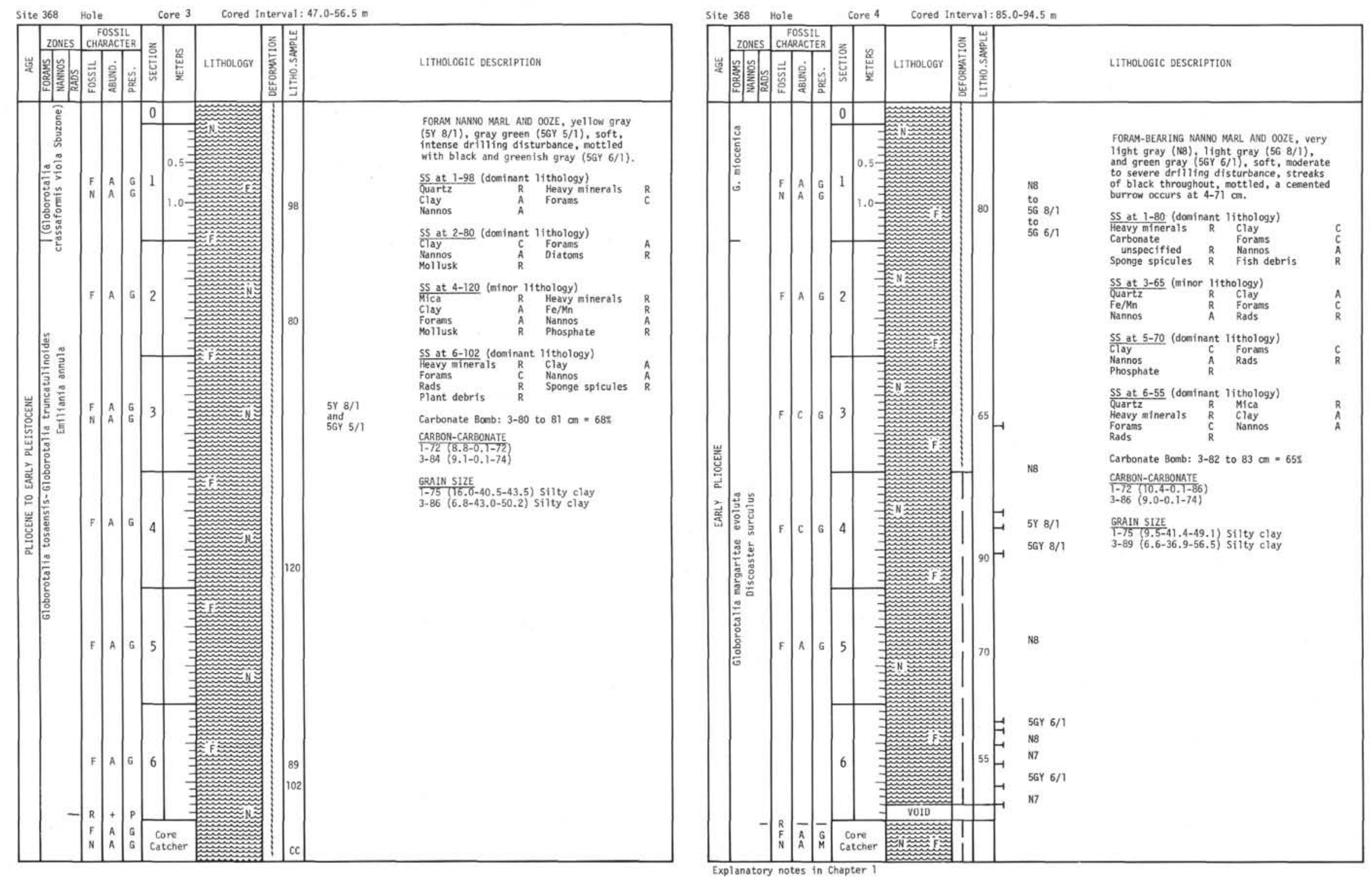

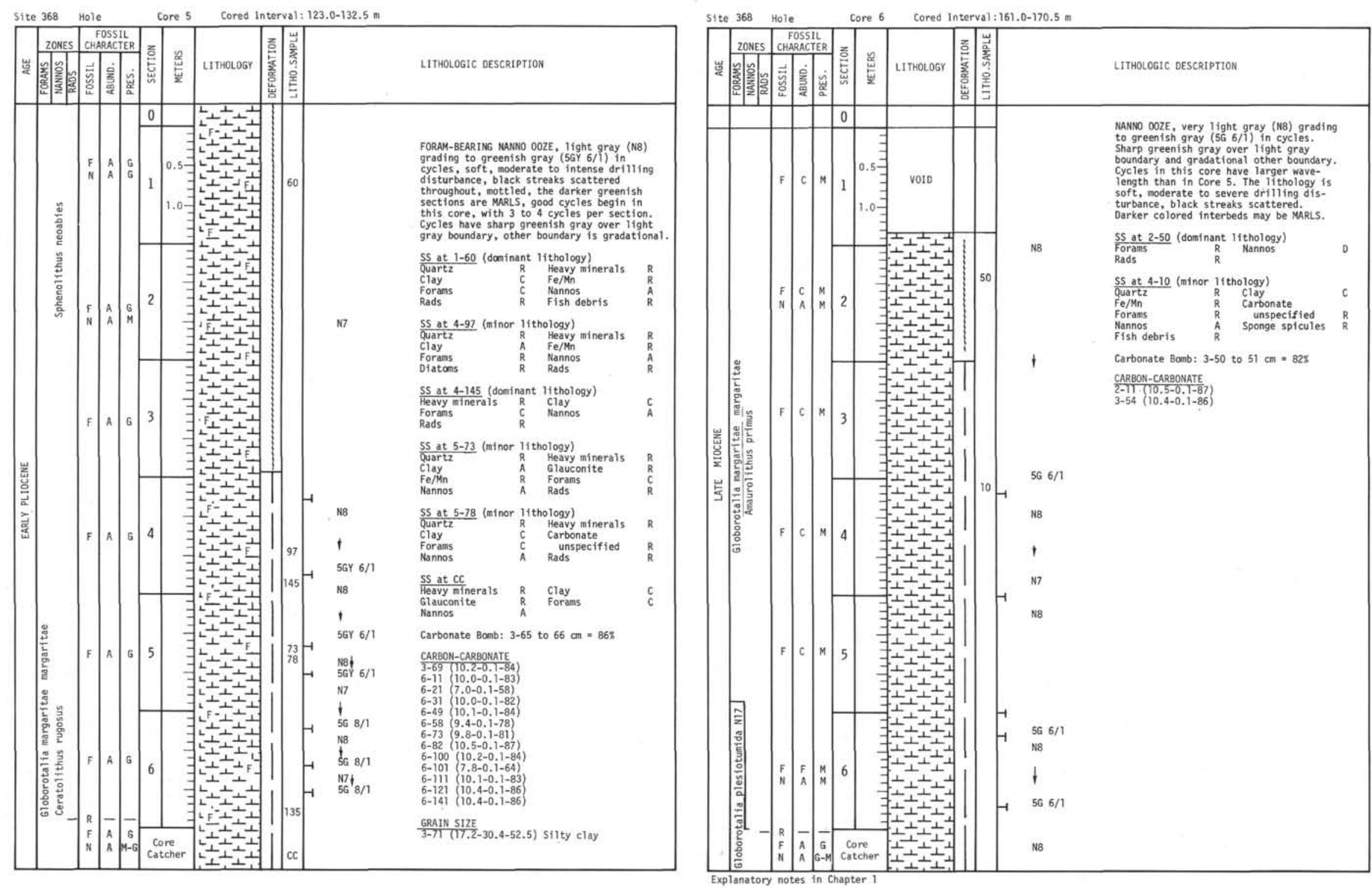


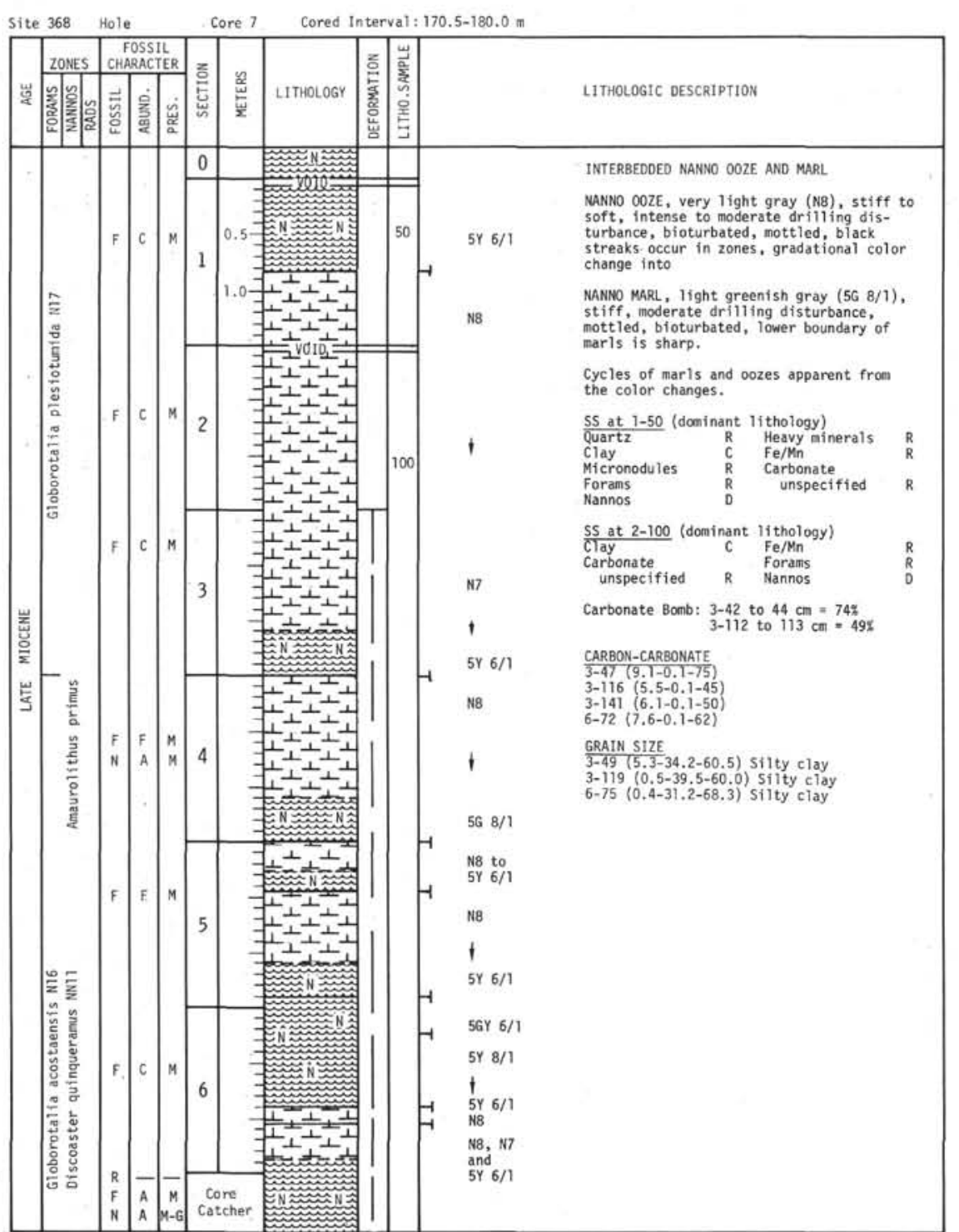

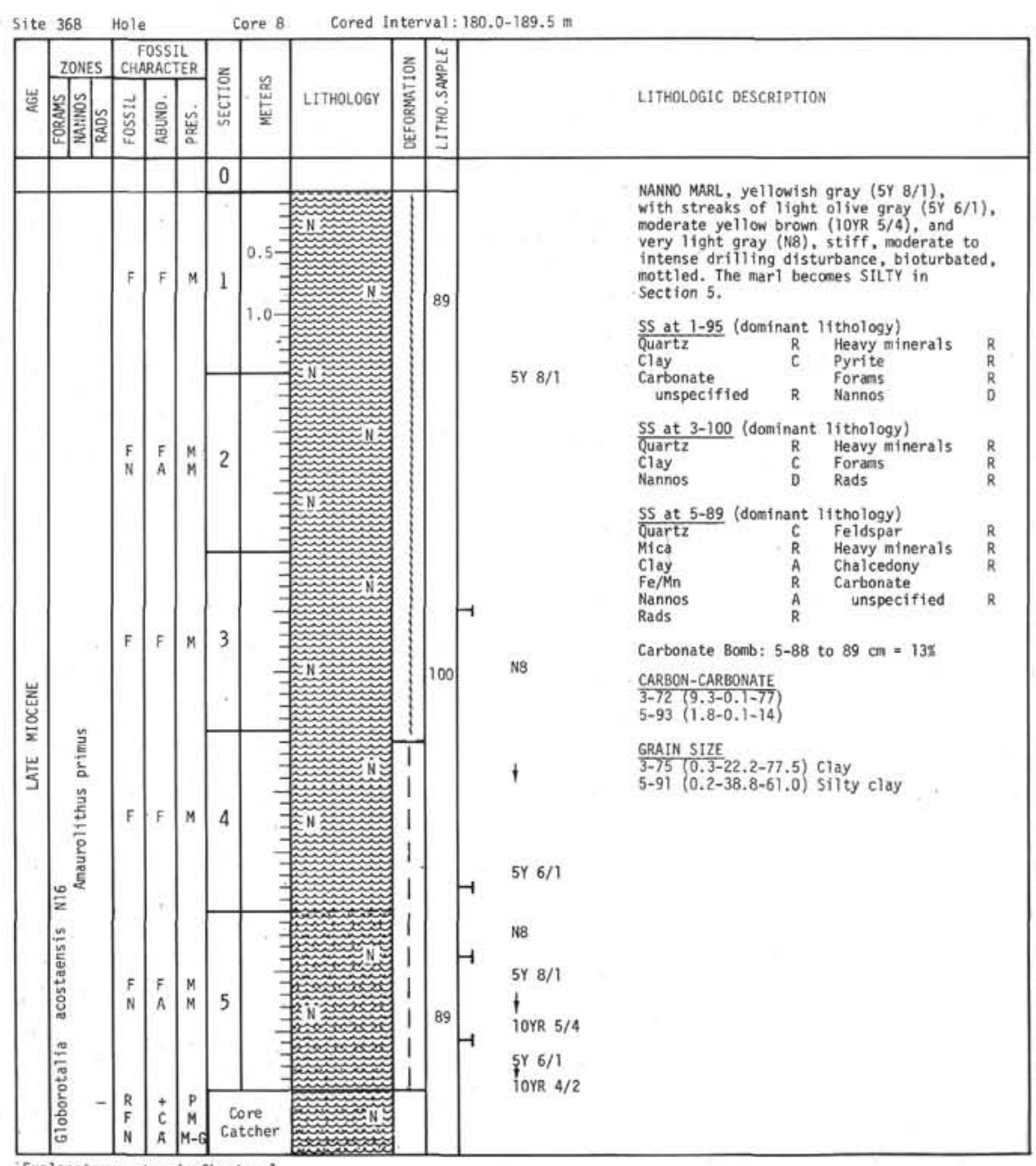




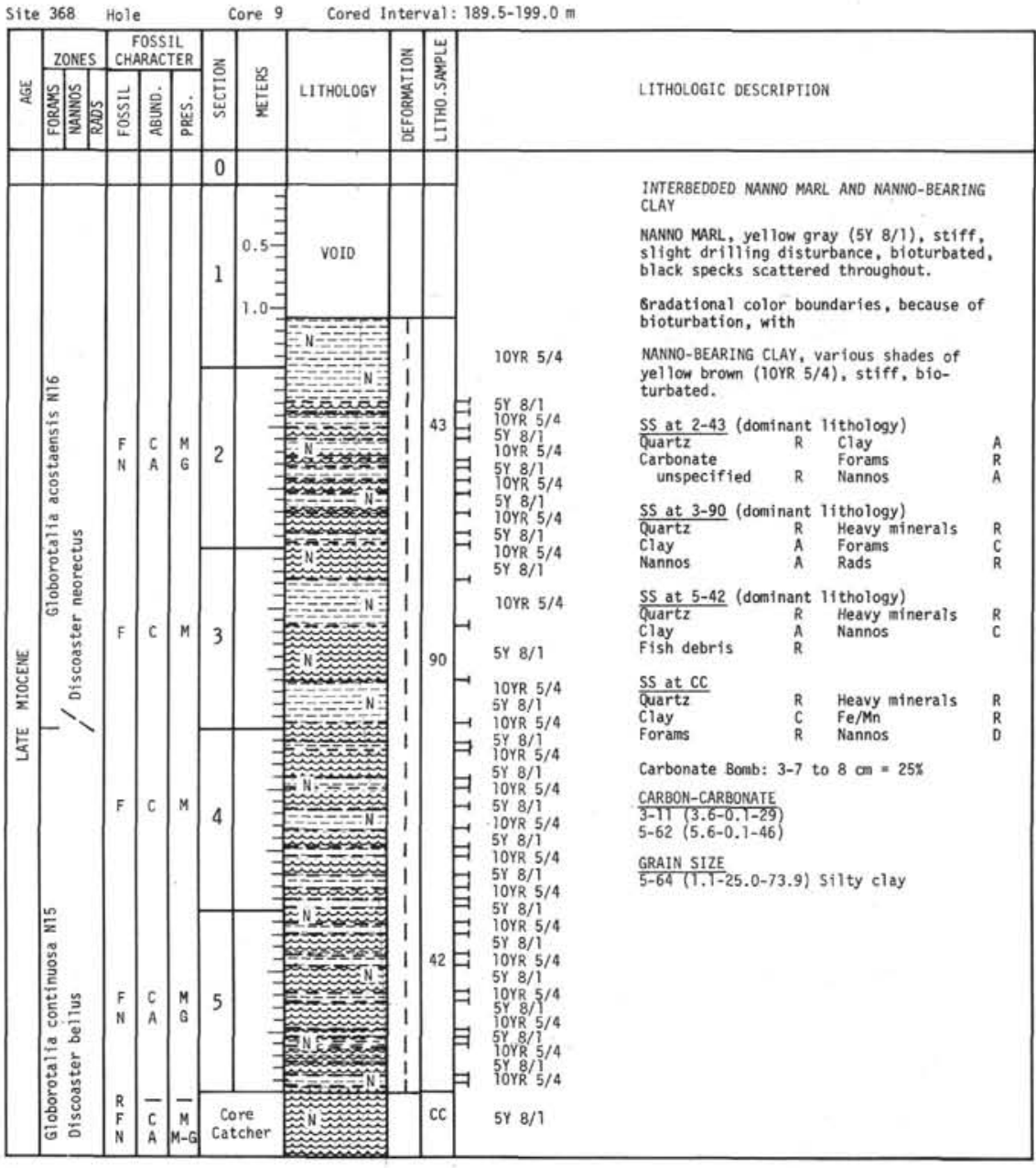

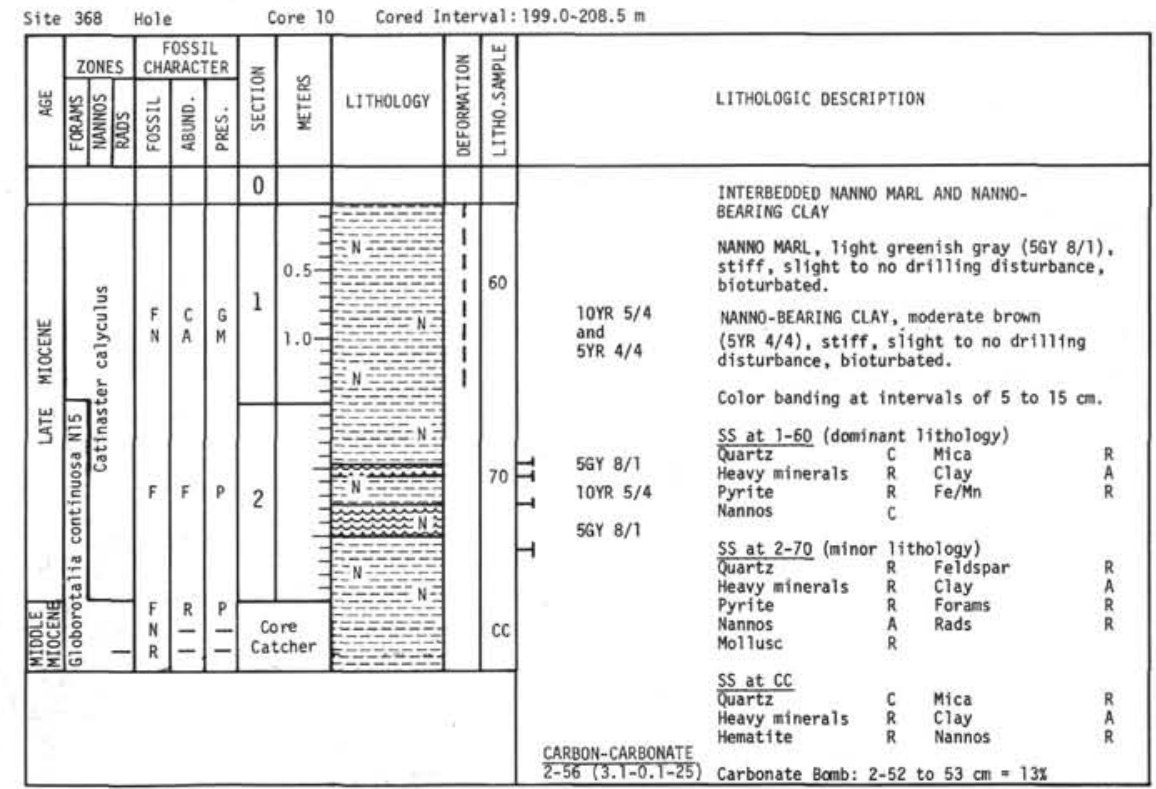

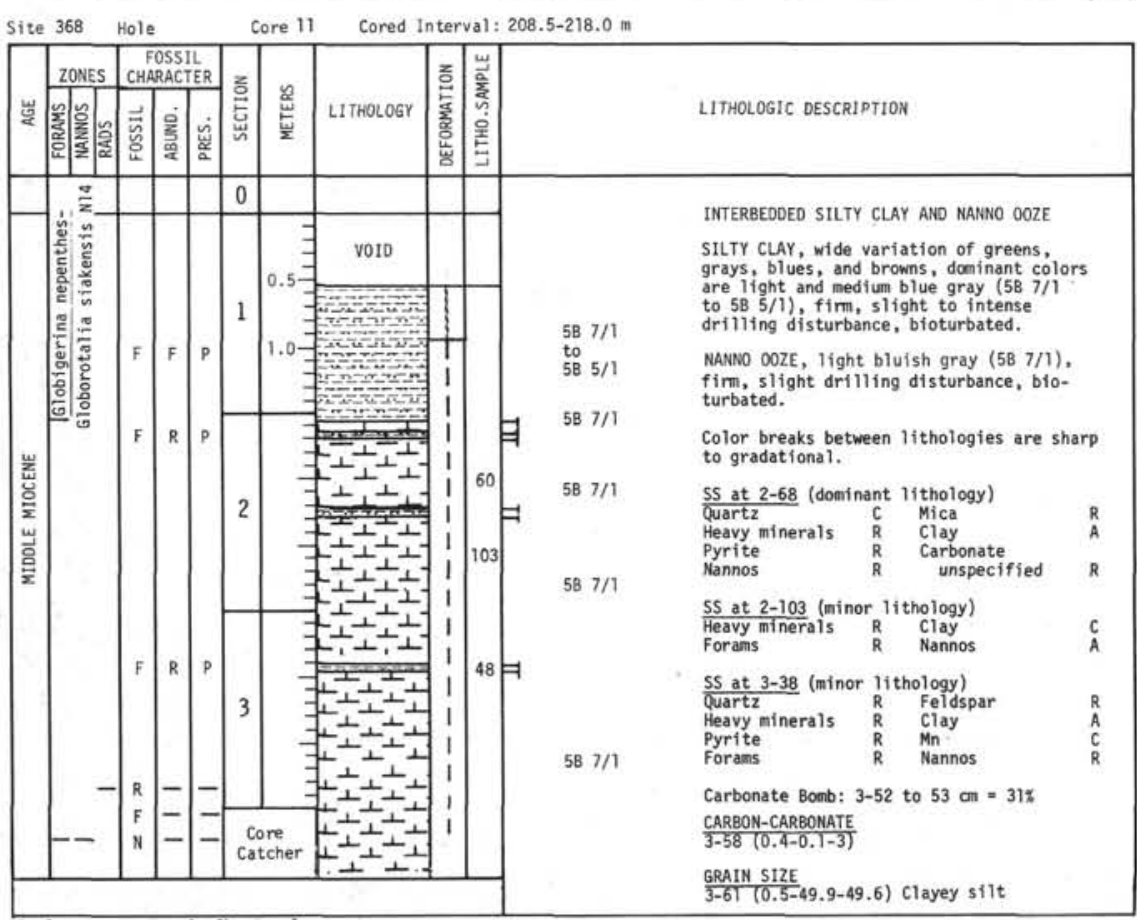




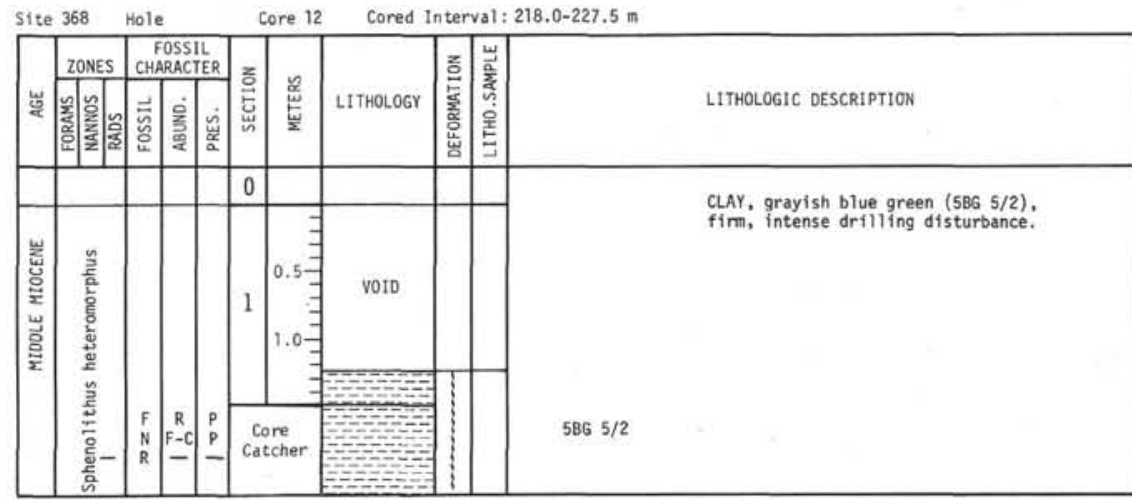

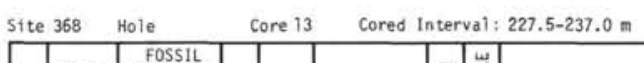

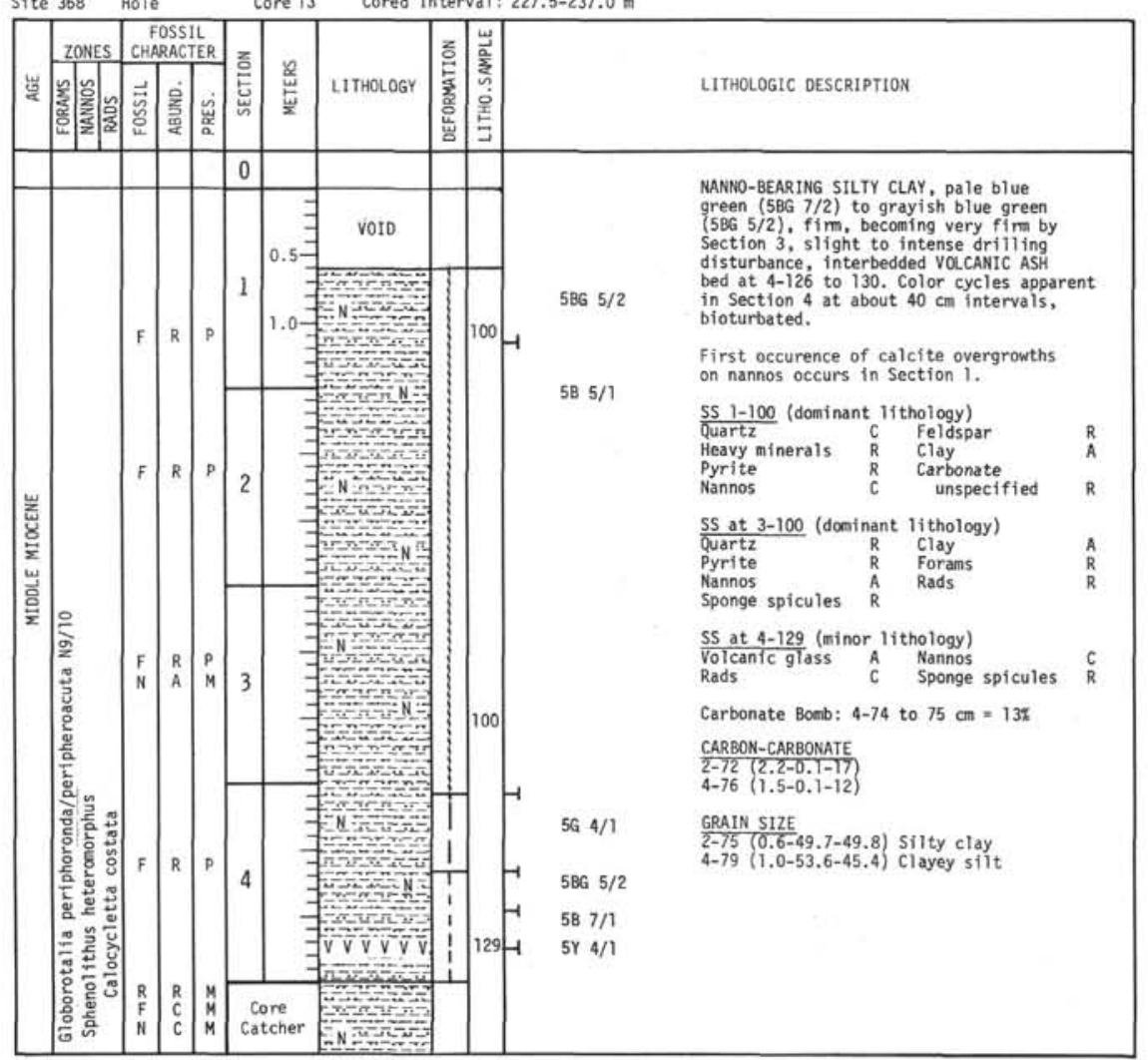

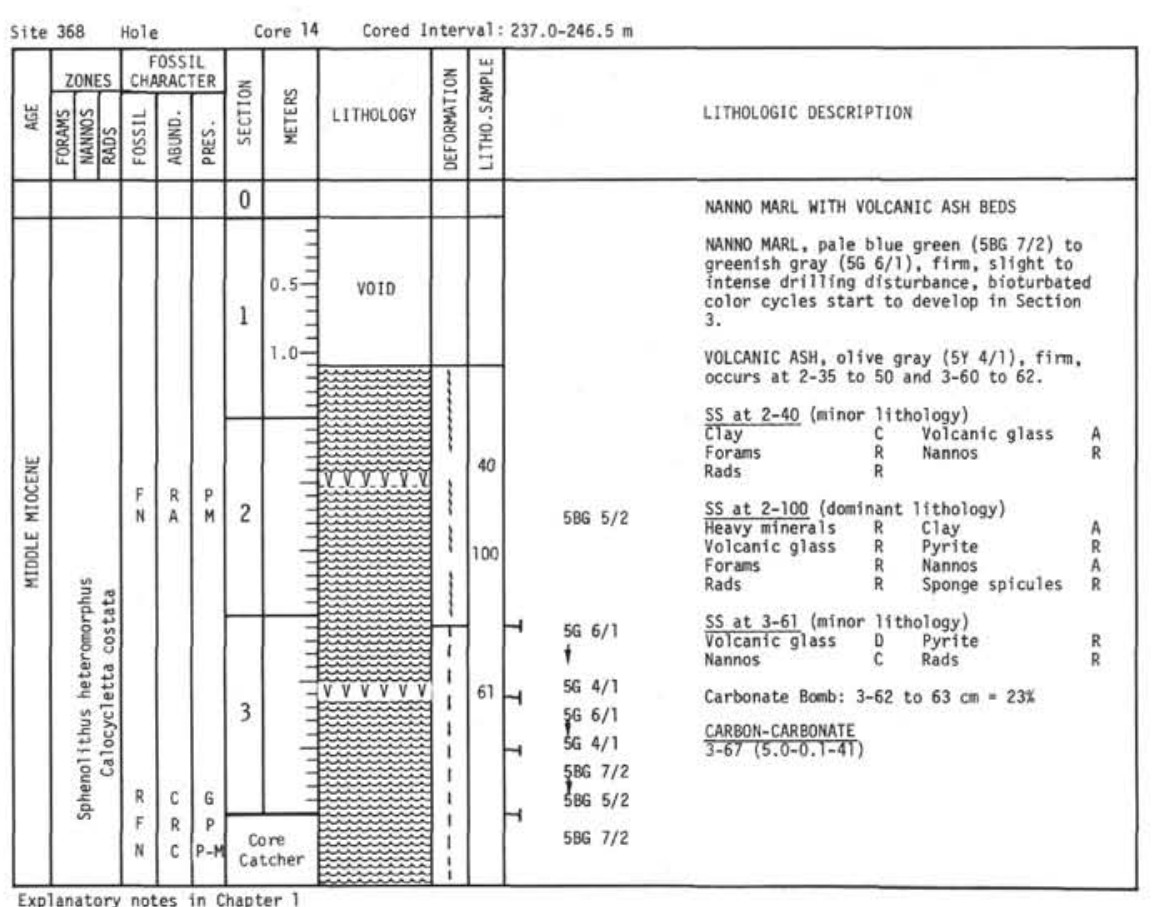

Explanatory notes in Chapter 1 


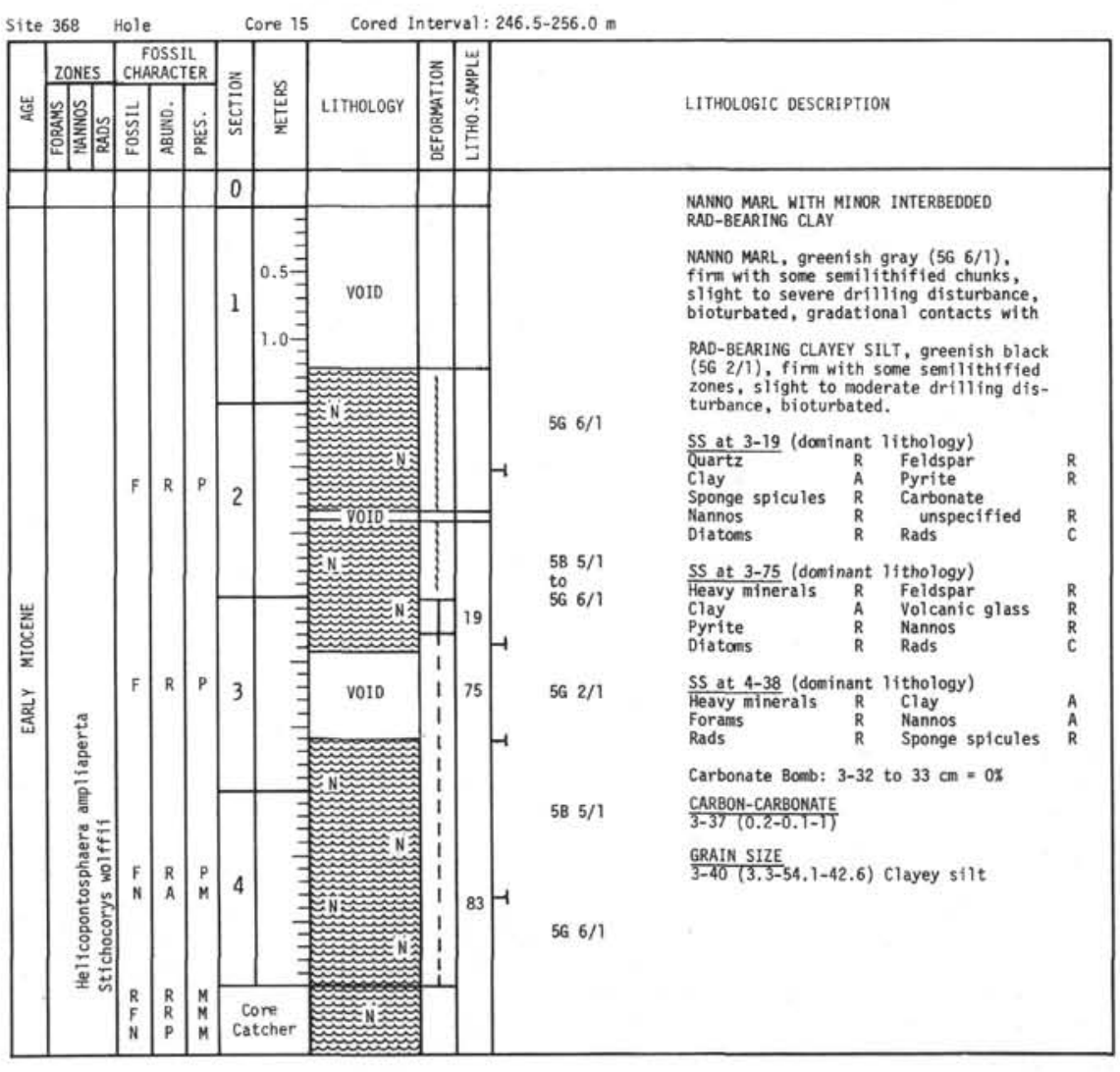

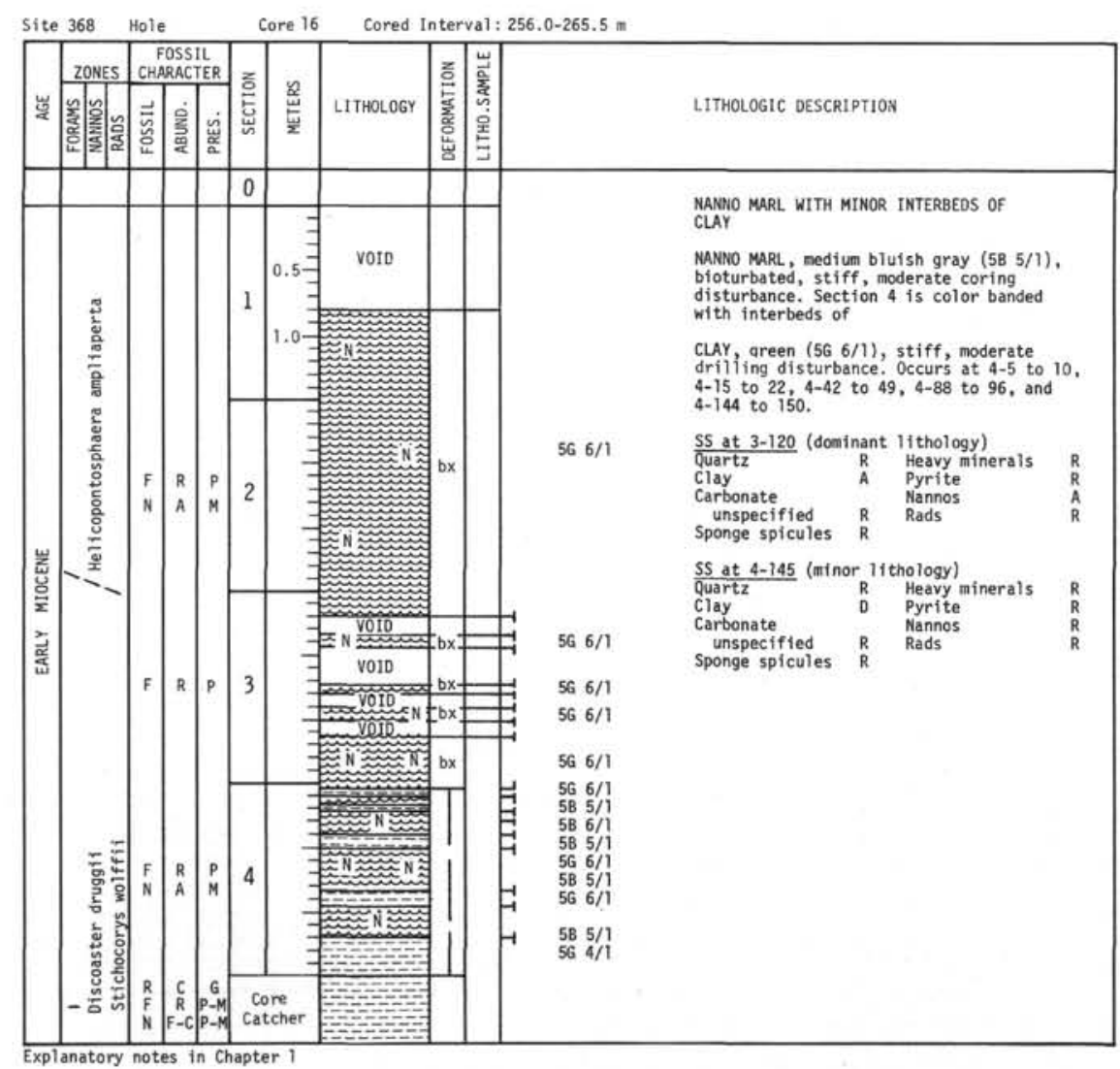



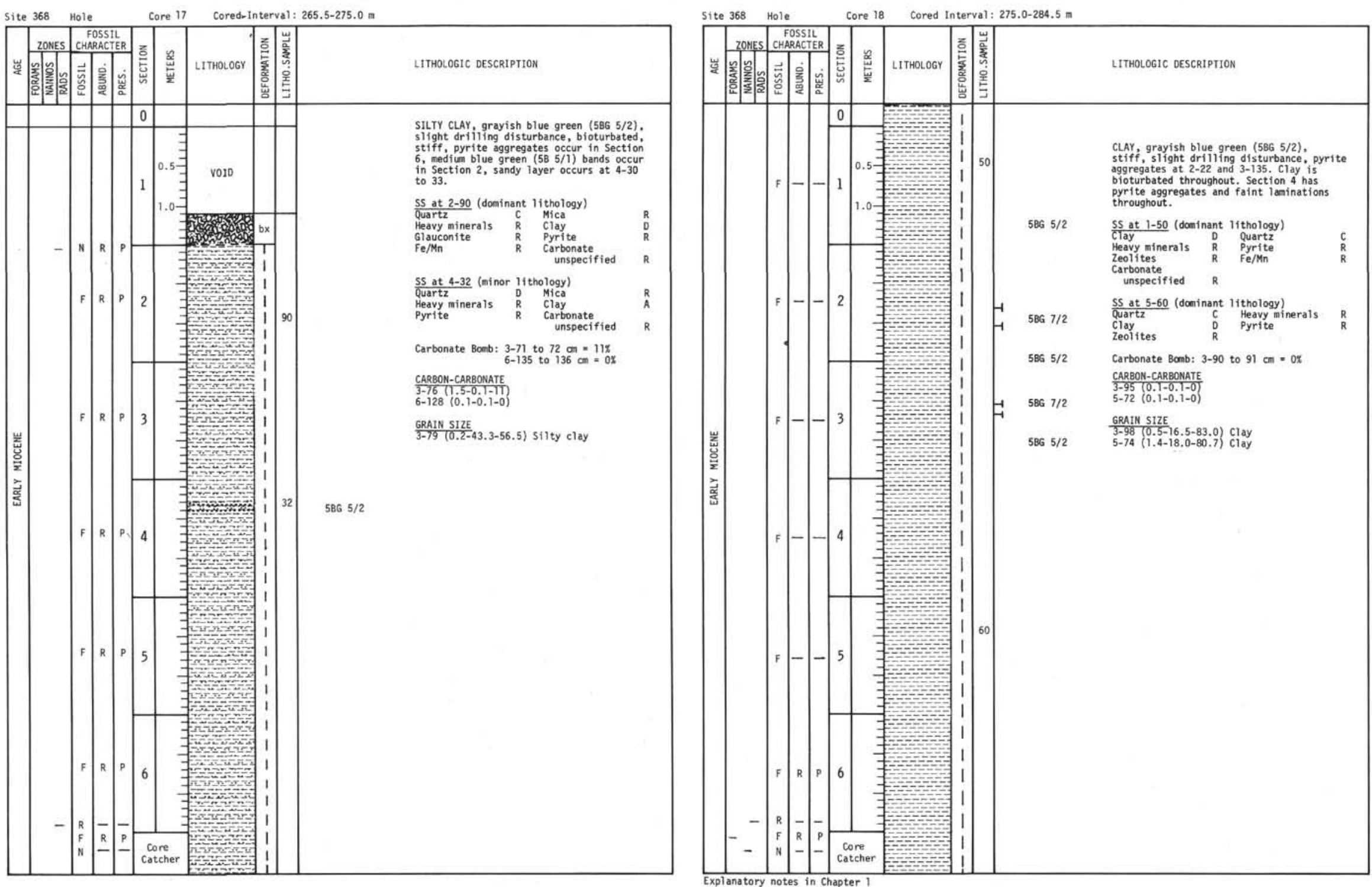

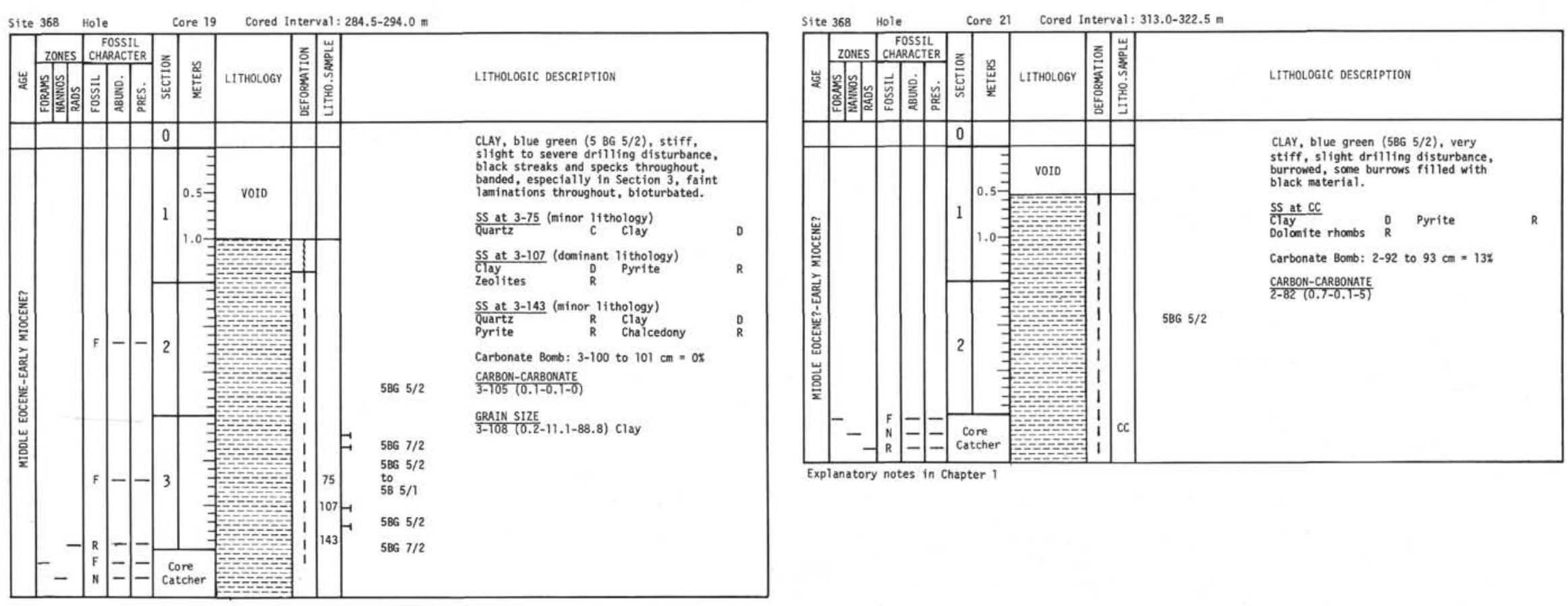

\begin{tabular}{|l|l|l|l|l|l|l|l|}
\hline Site 368 & Hole \\
\hline
\end{tabular}




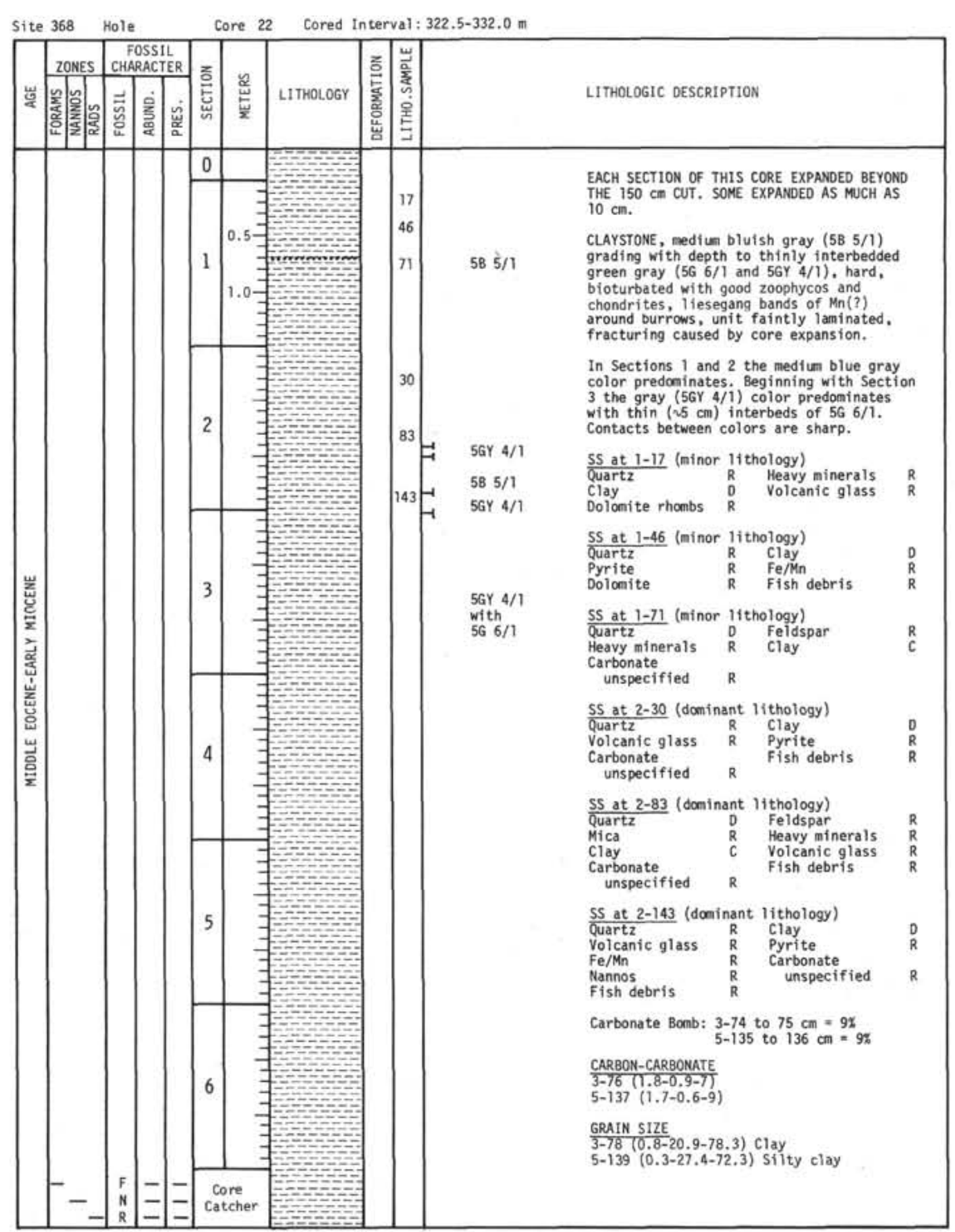

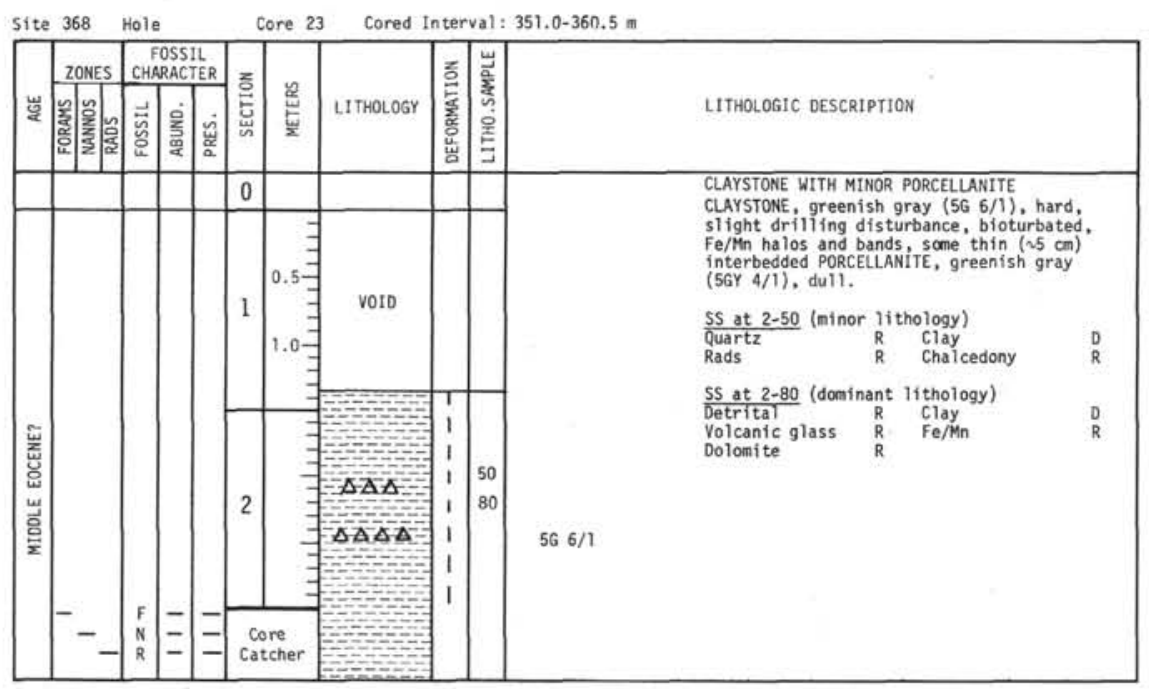

\begin{tabular}{|l|l|l|l|l|l|l|l|}
\hline Site 368 & Hole \\
\hline
\end{tabular}




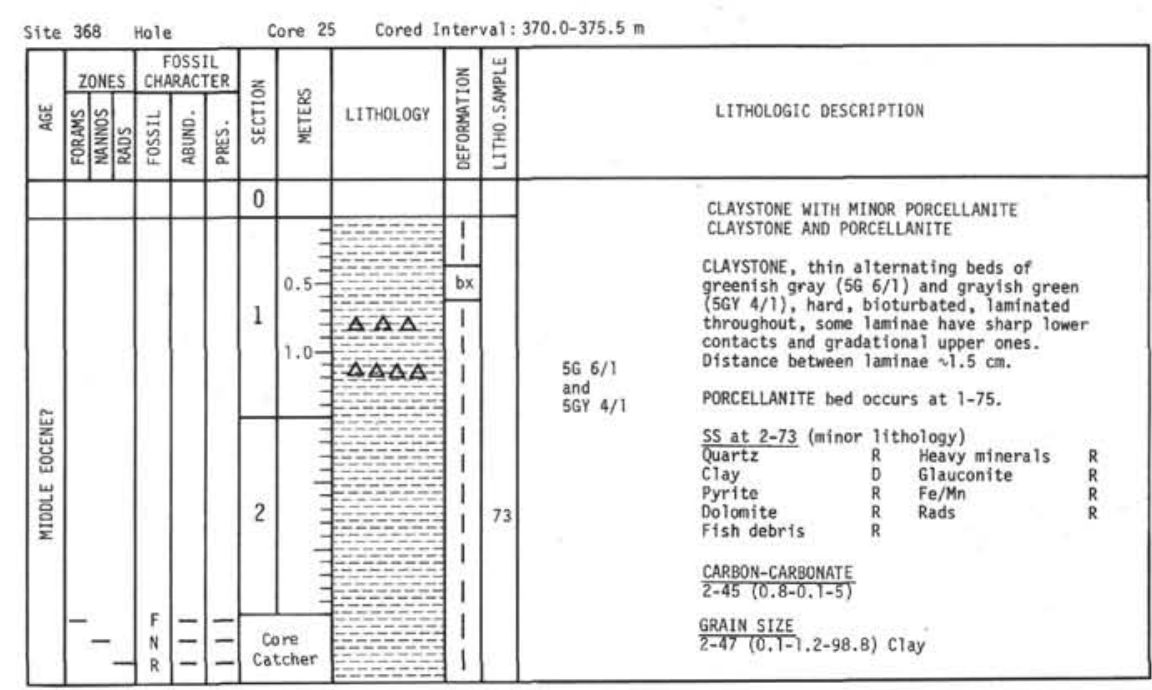

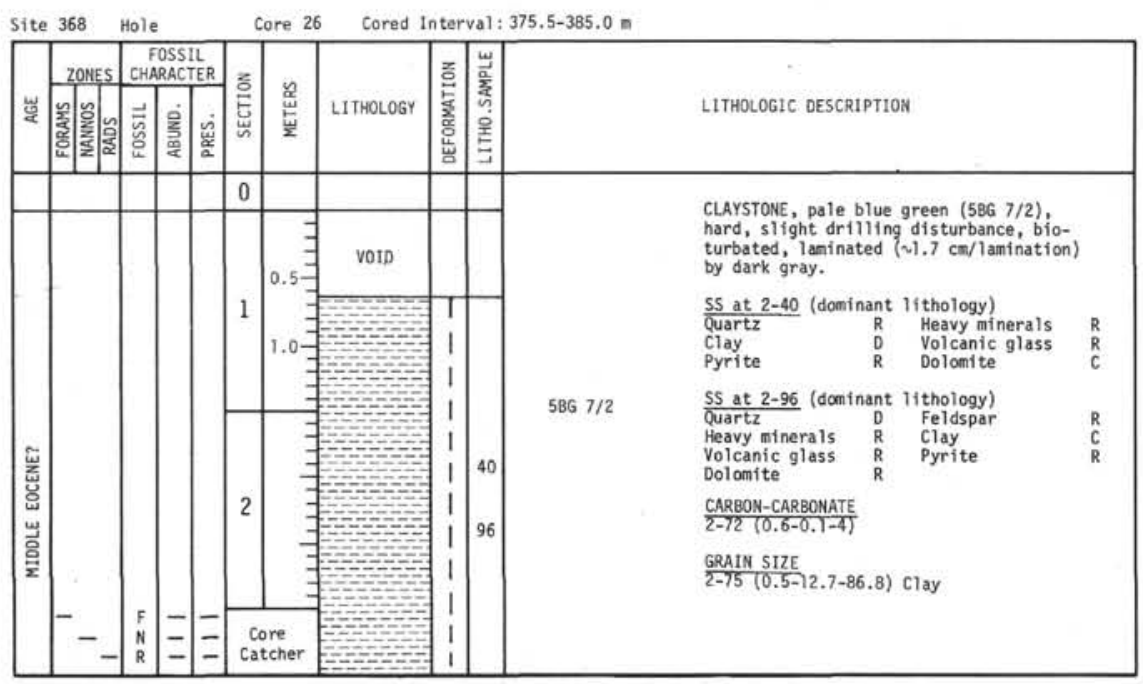

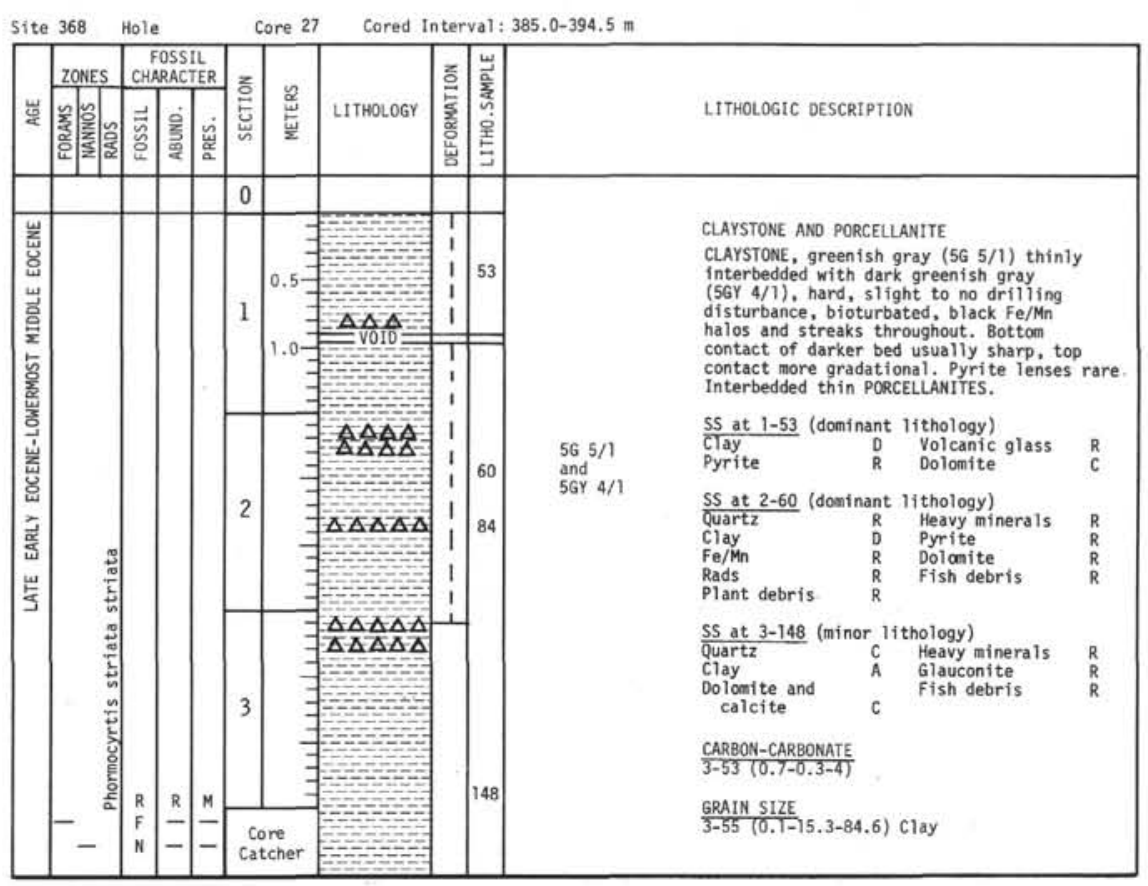

Site 368 Hole Core 28 Cored Interval: $394.5-404.0 \mathrm{~m}$

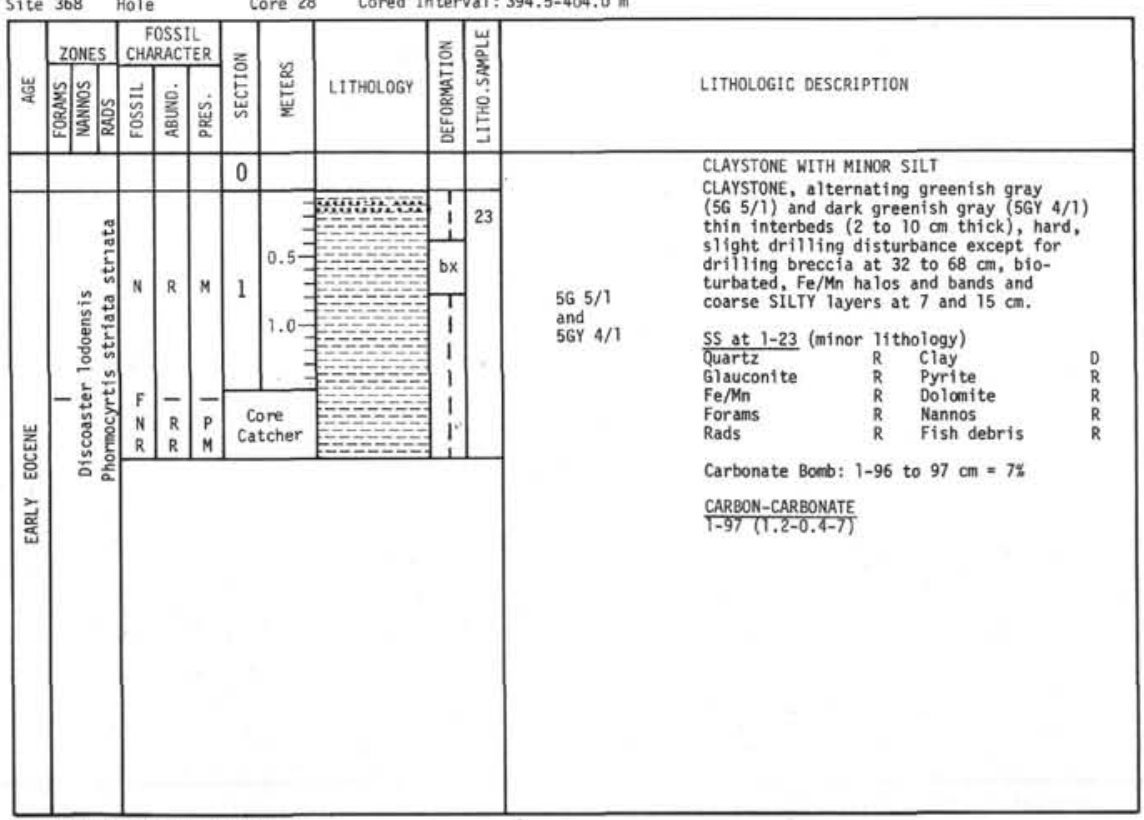




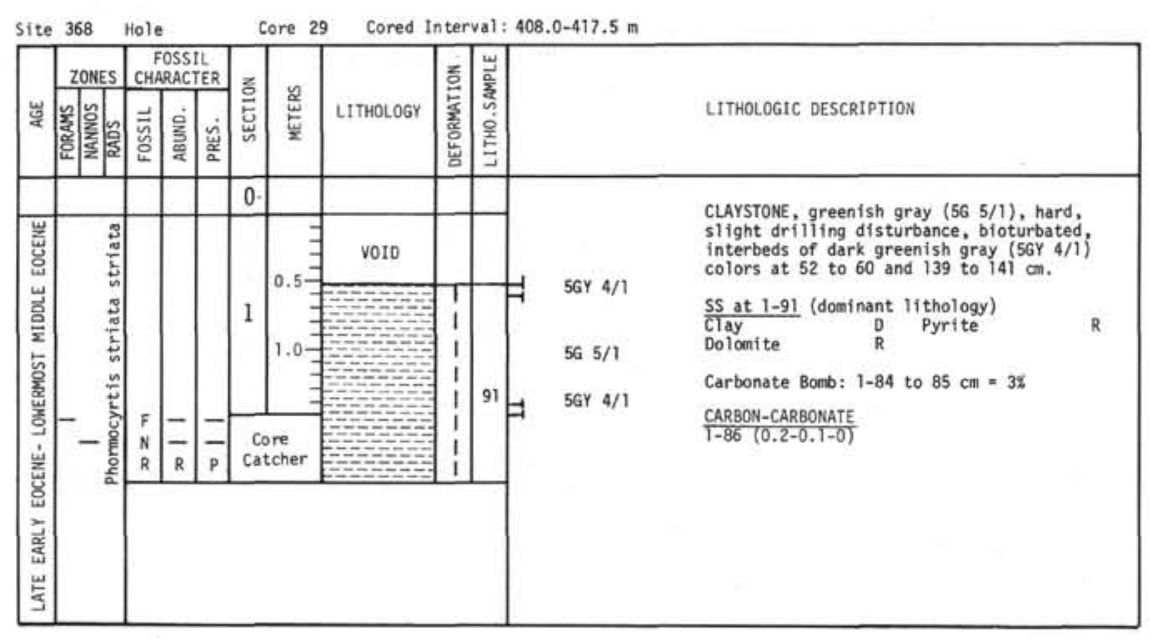

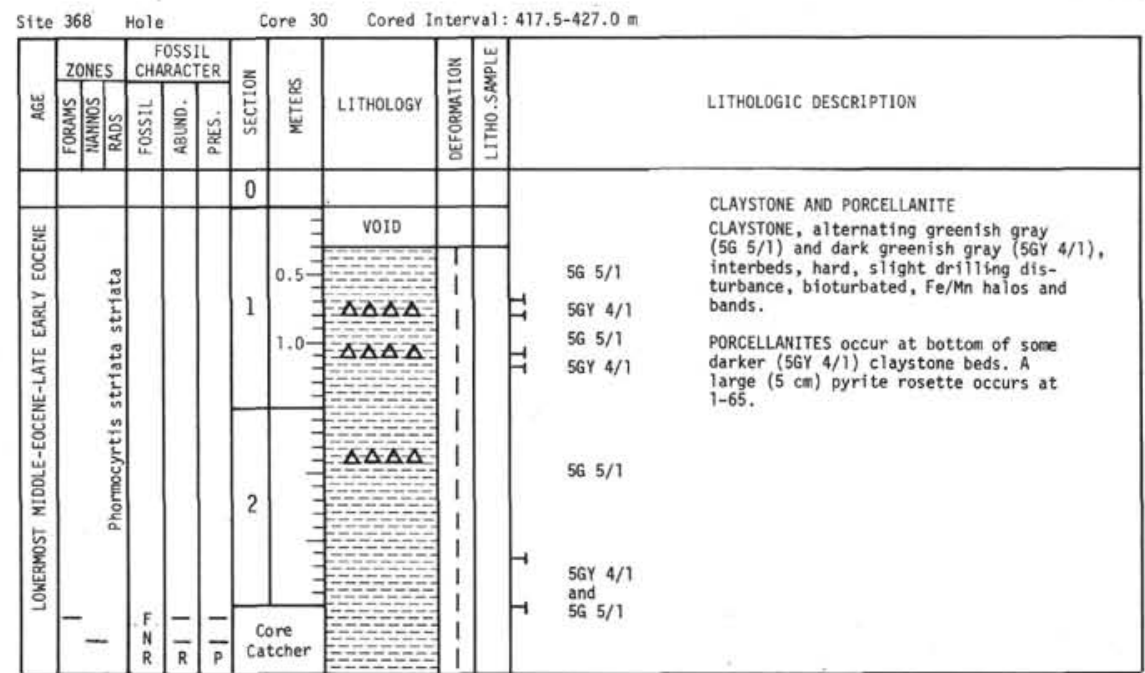

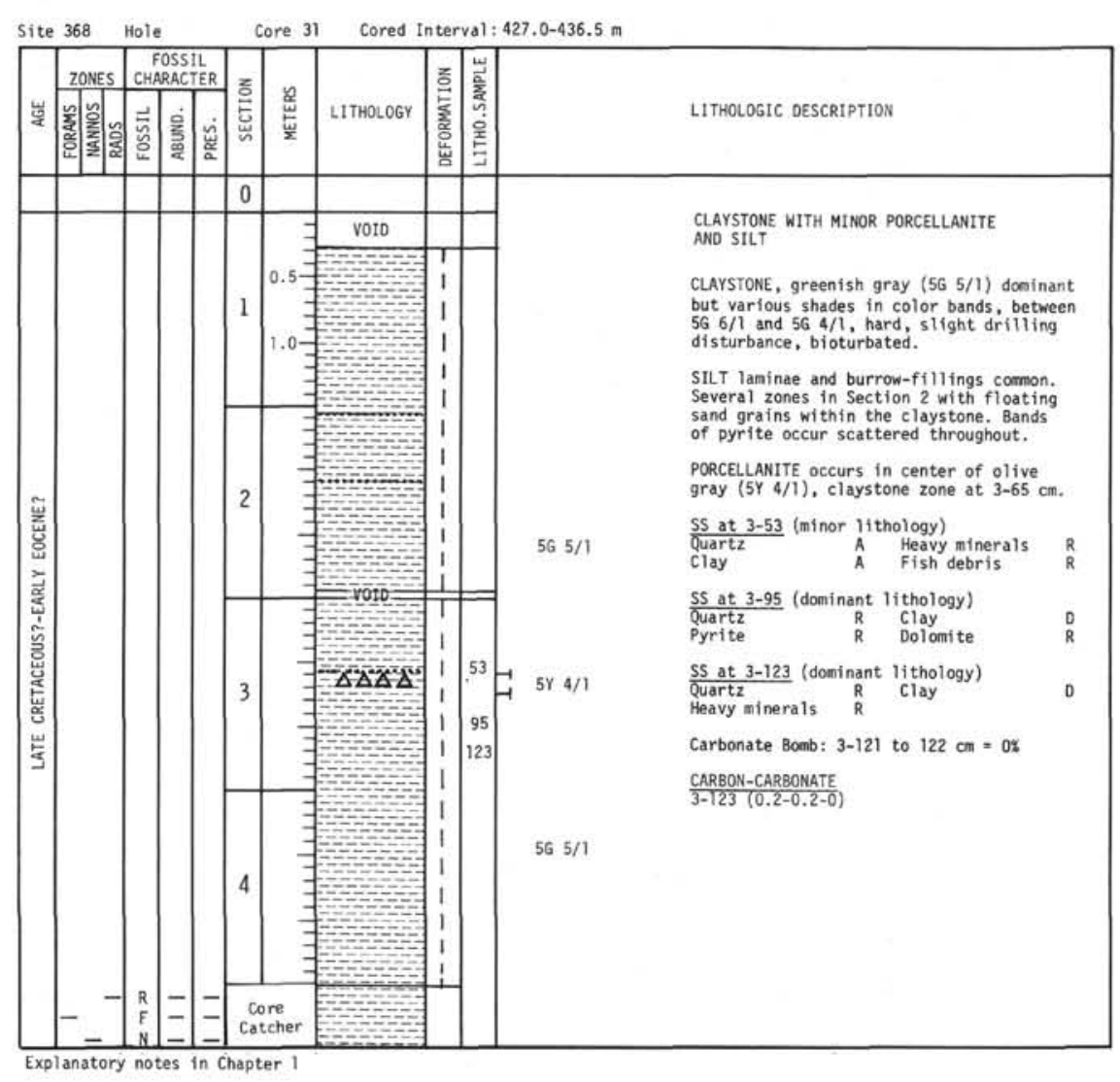




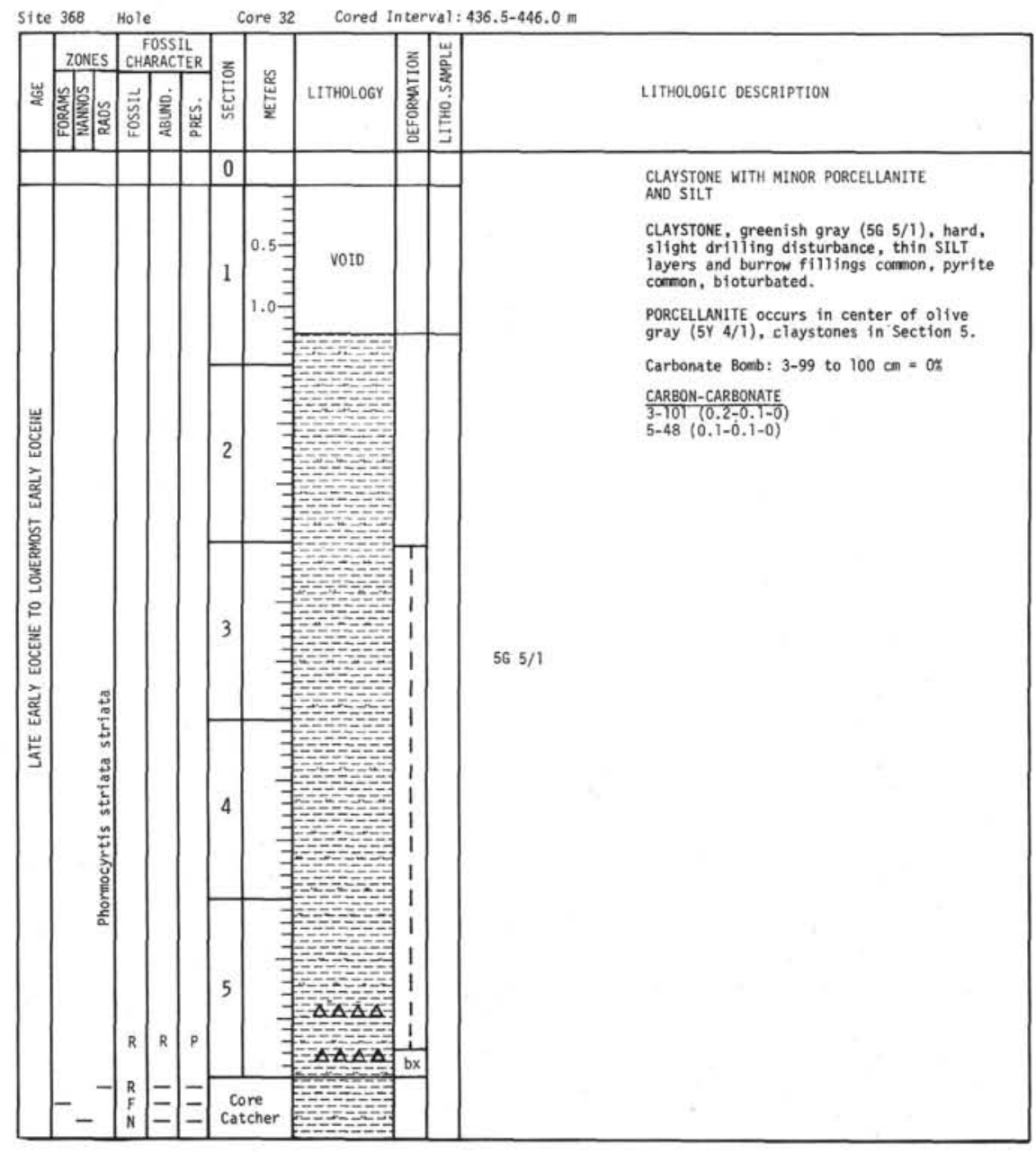

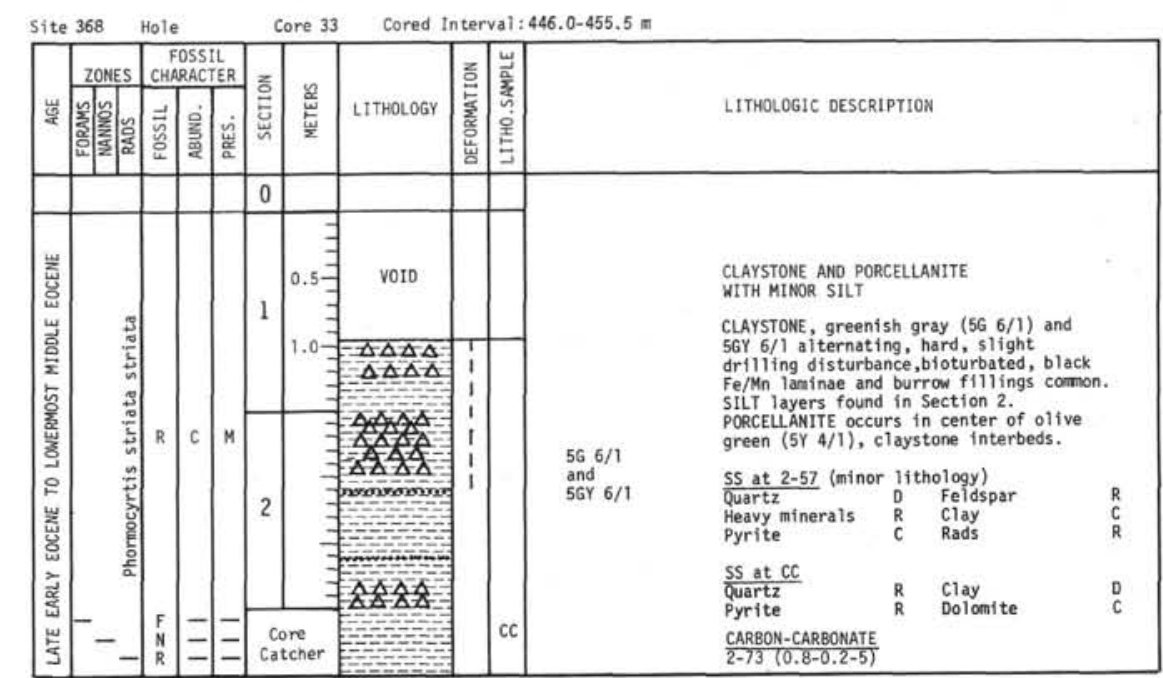

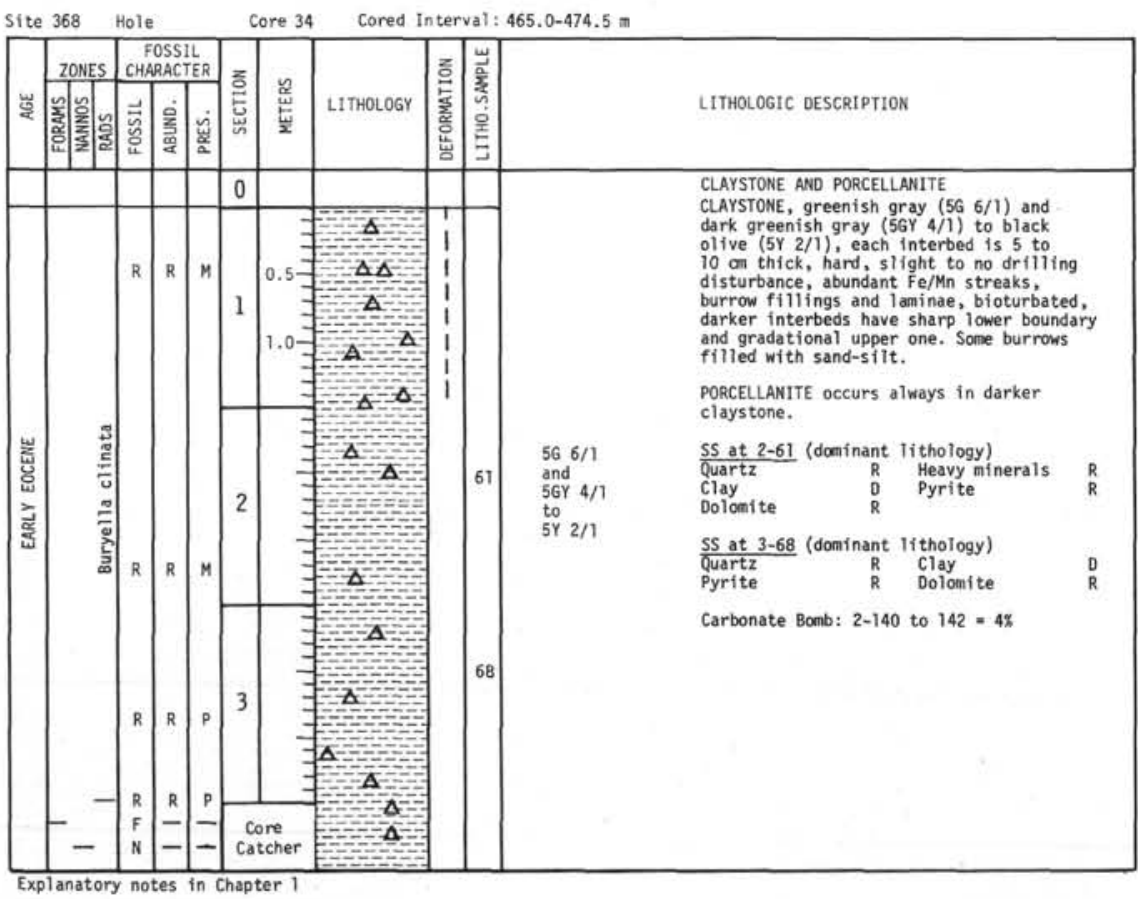

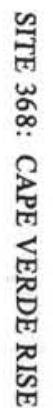




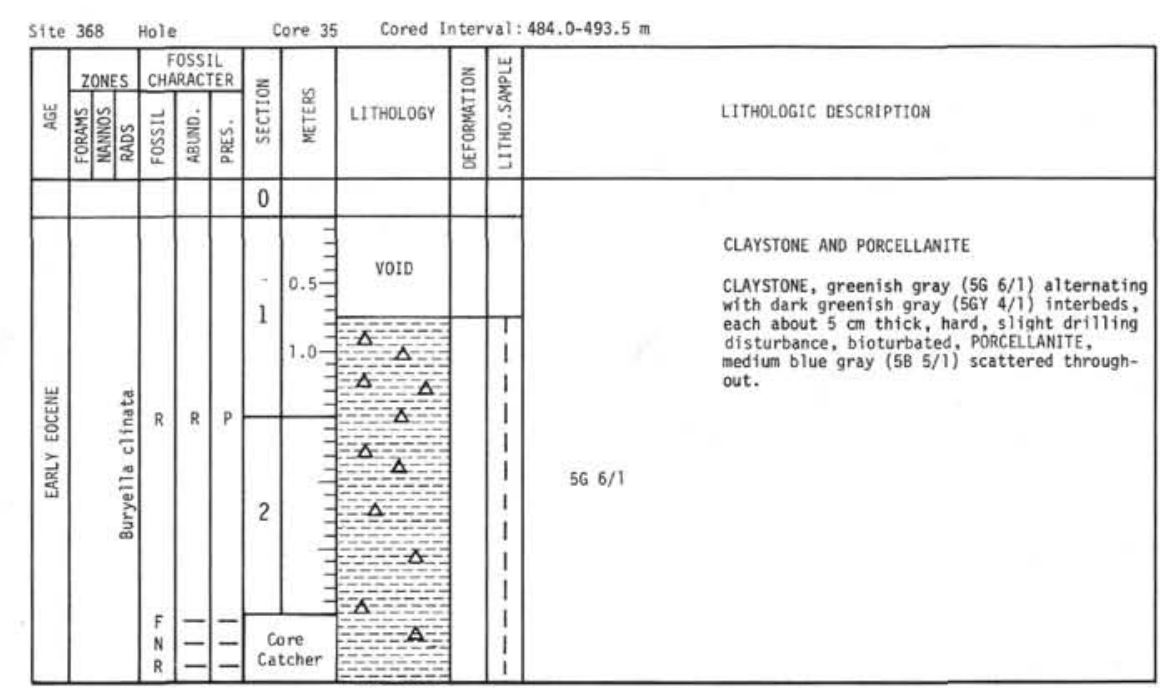

\begin{tabular}{|l|l|l|l|l|l|l|l|l|}
\hline & \\
\hline
\end{tabular}

\begin{tabular}{|l|l|l|l|l|l|l|l|l|}
\hline & & \\
\end{tabular}




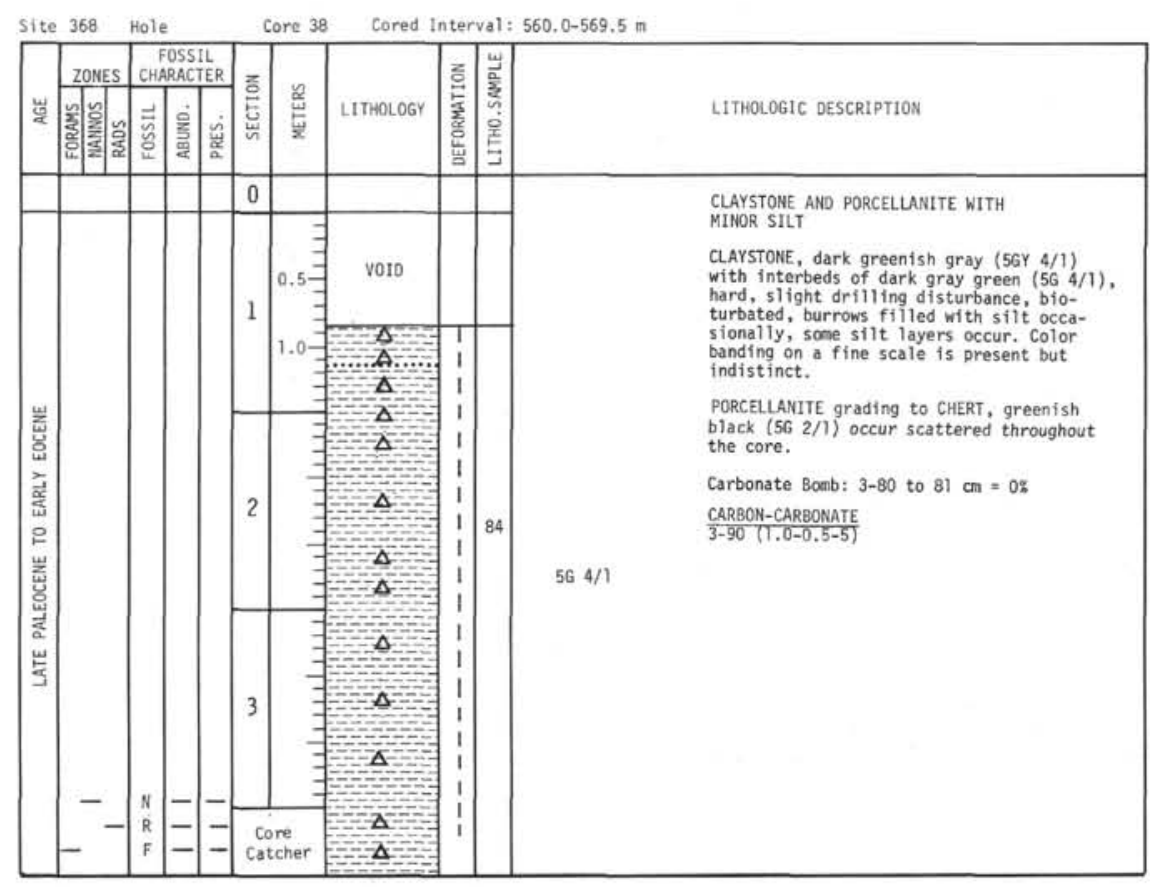

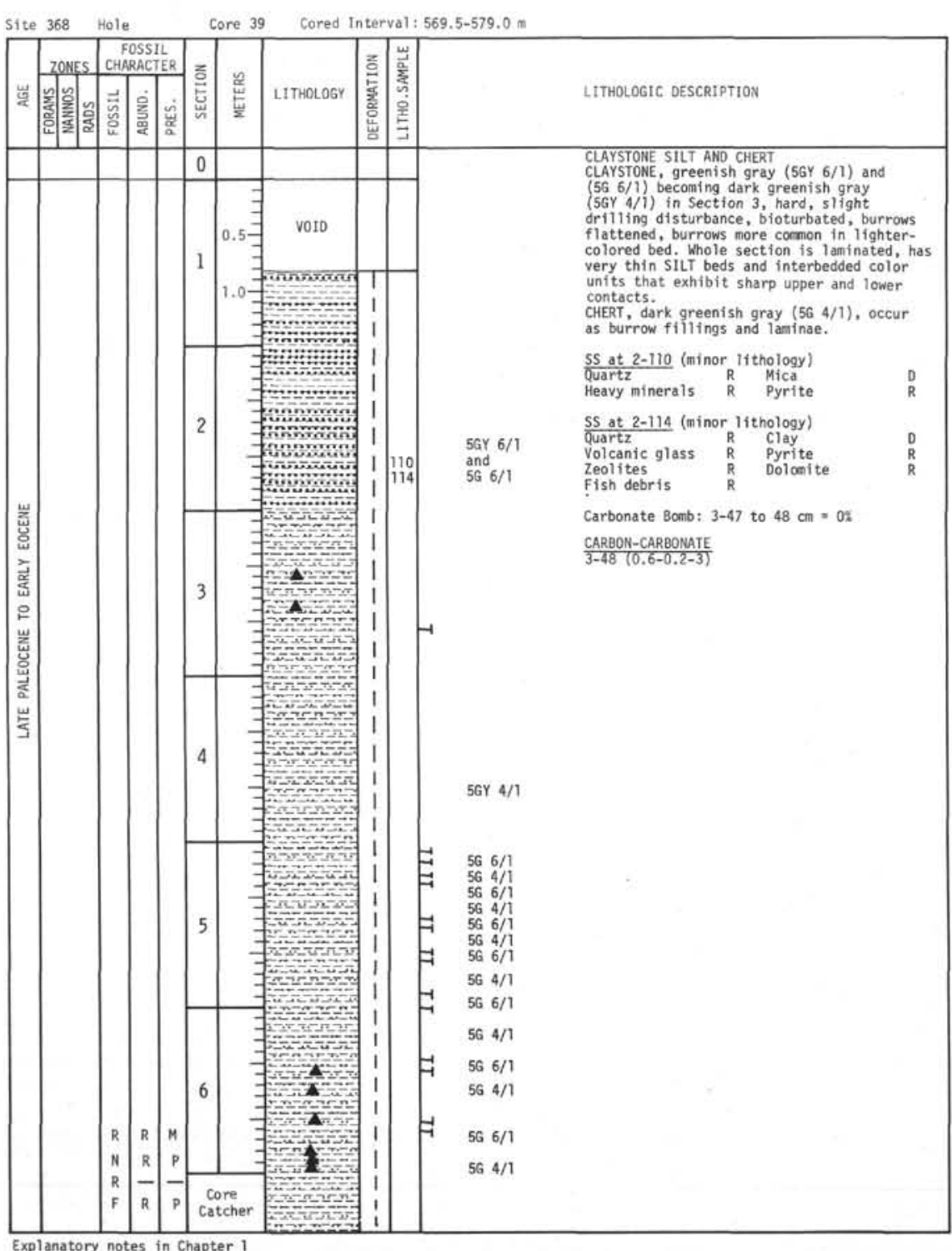

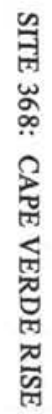




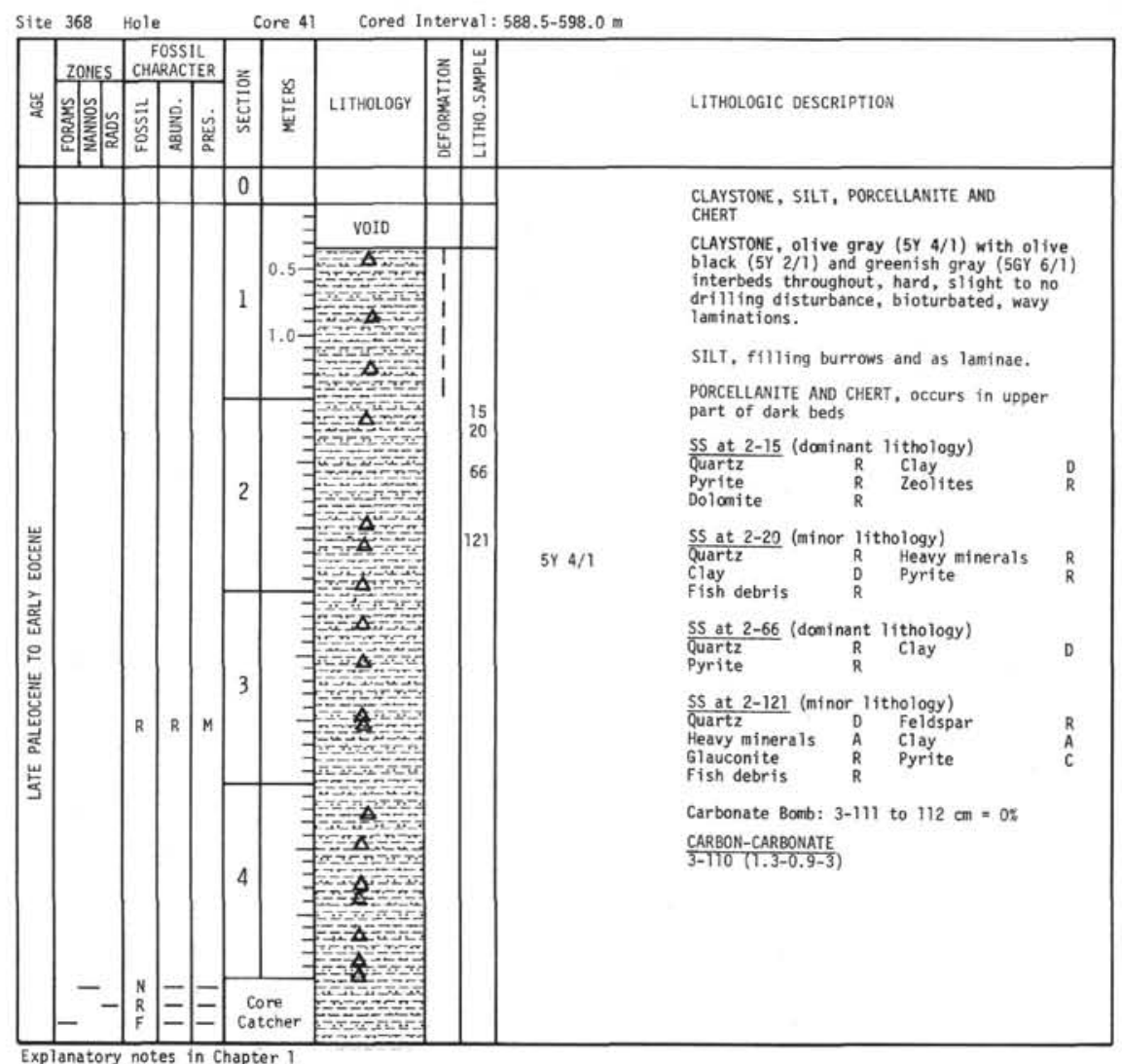




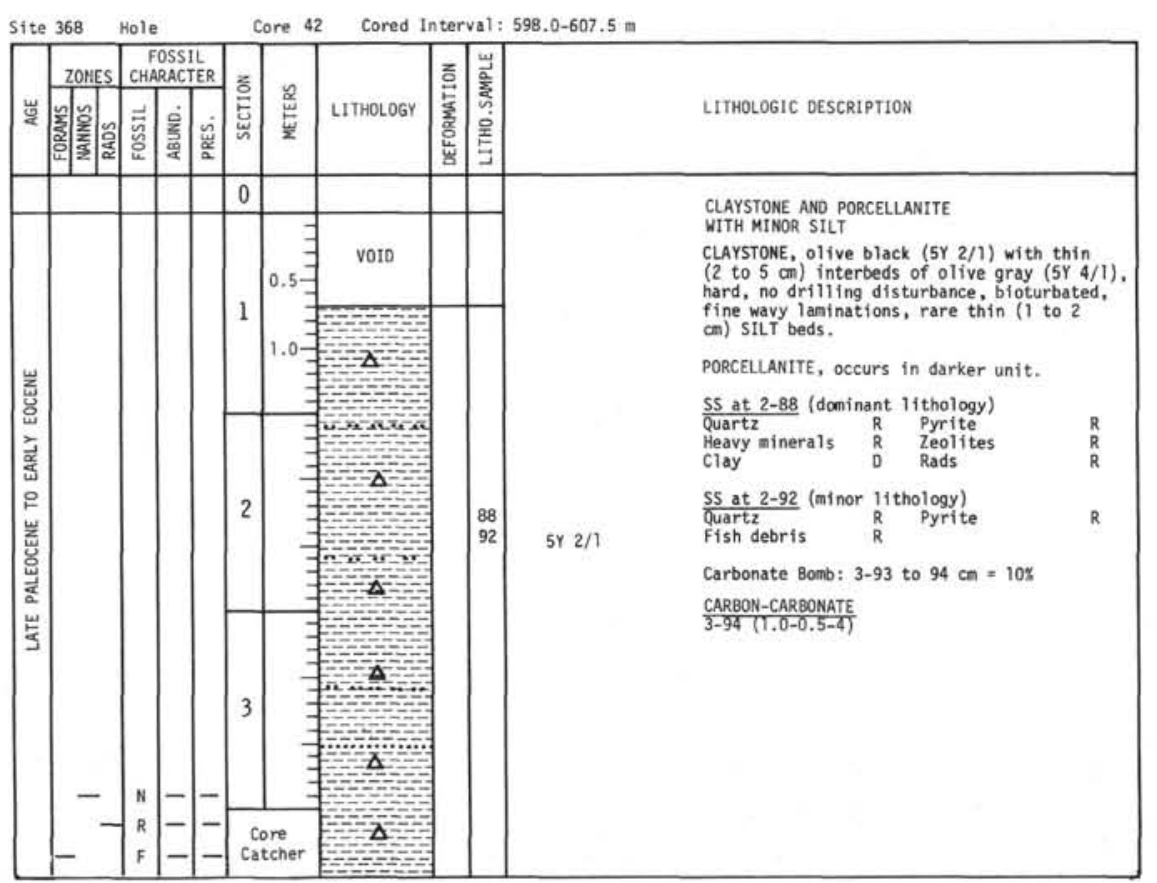

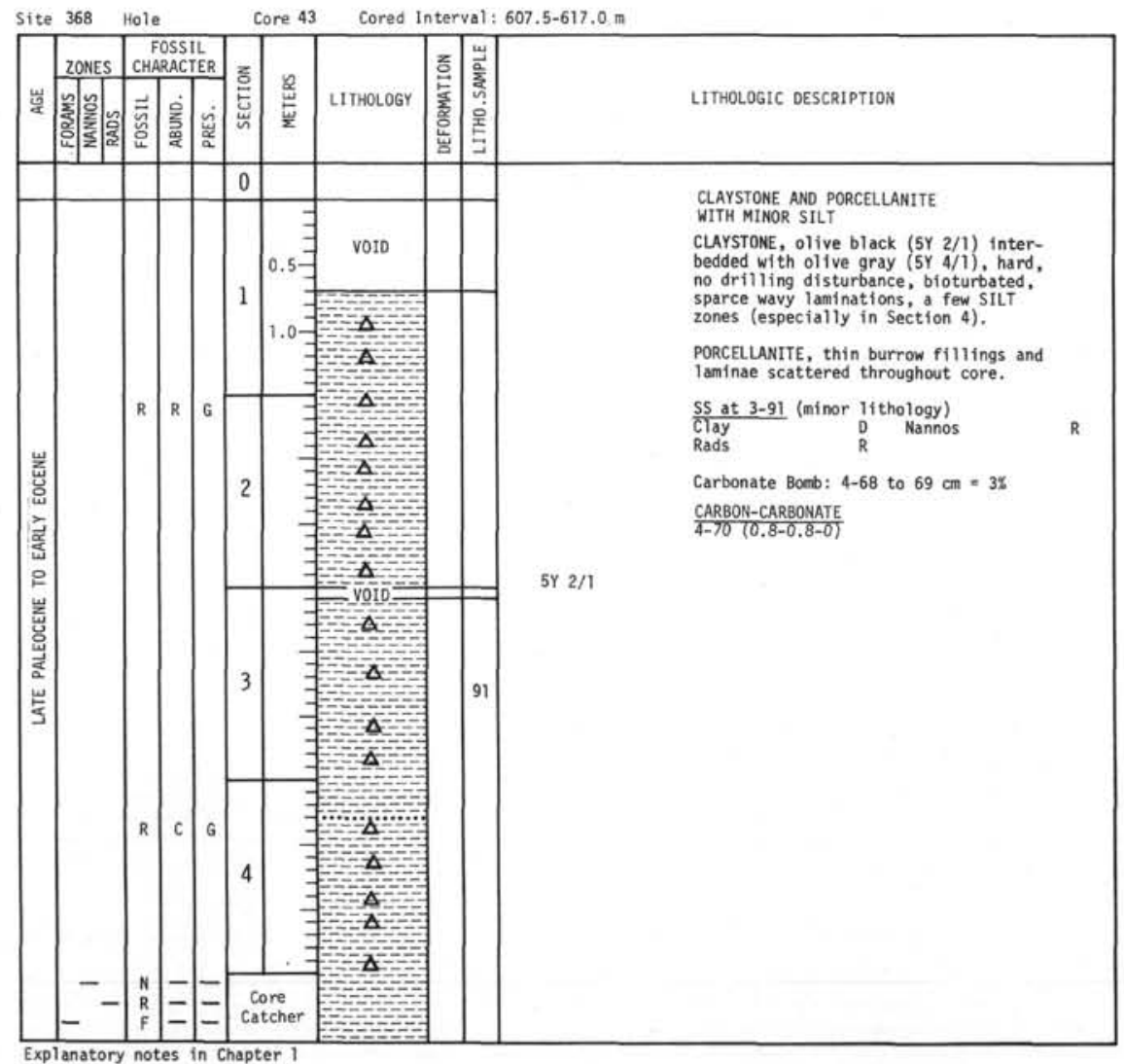

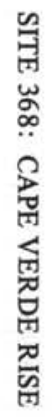



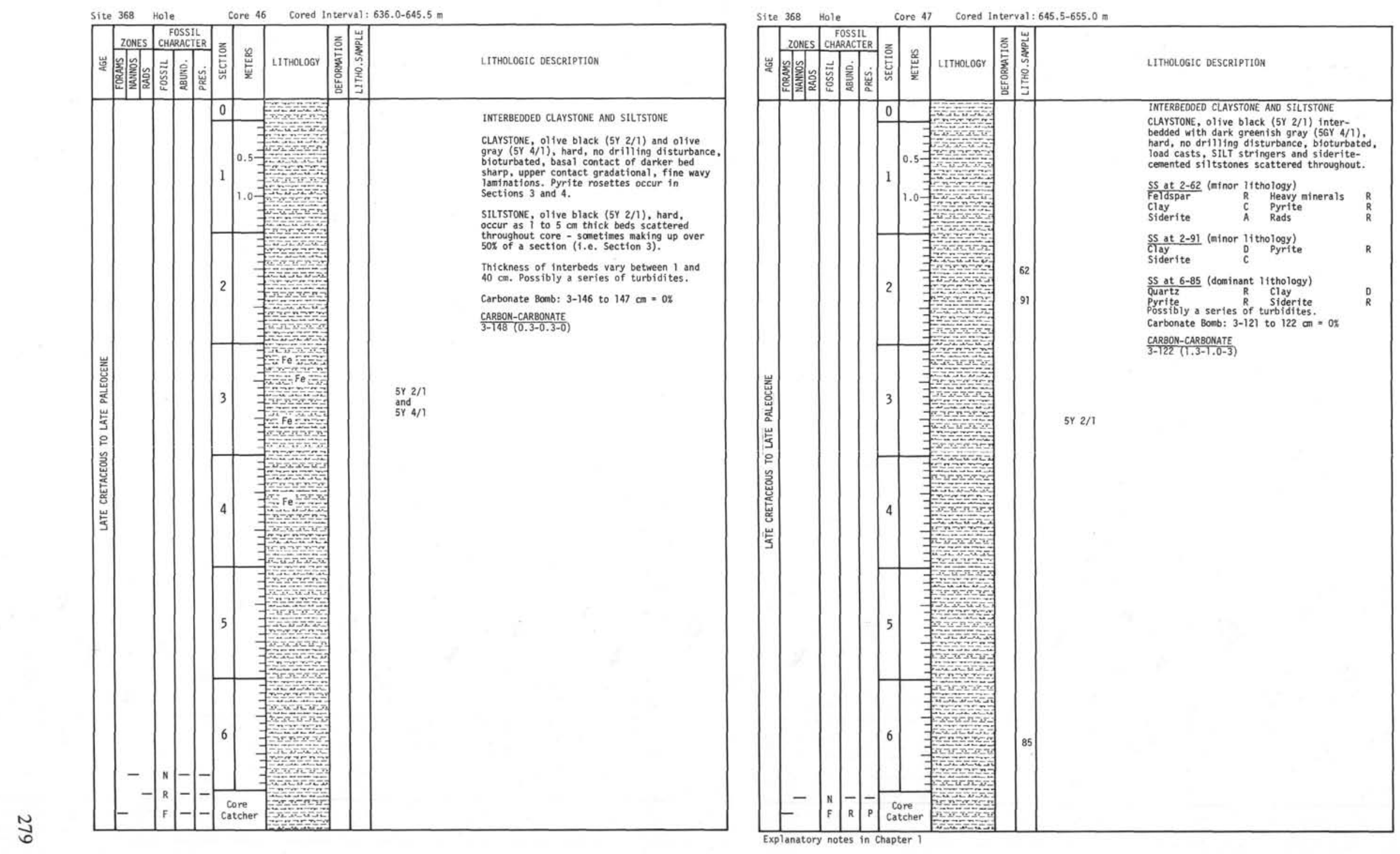


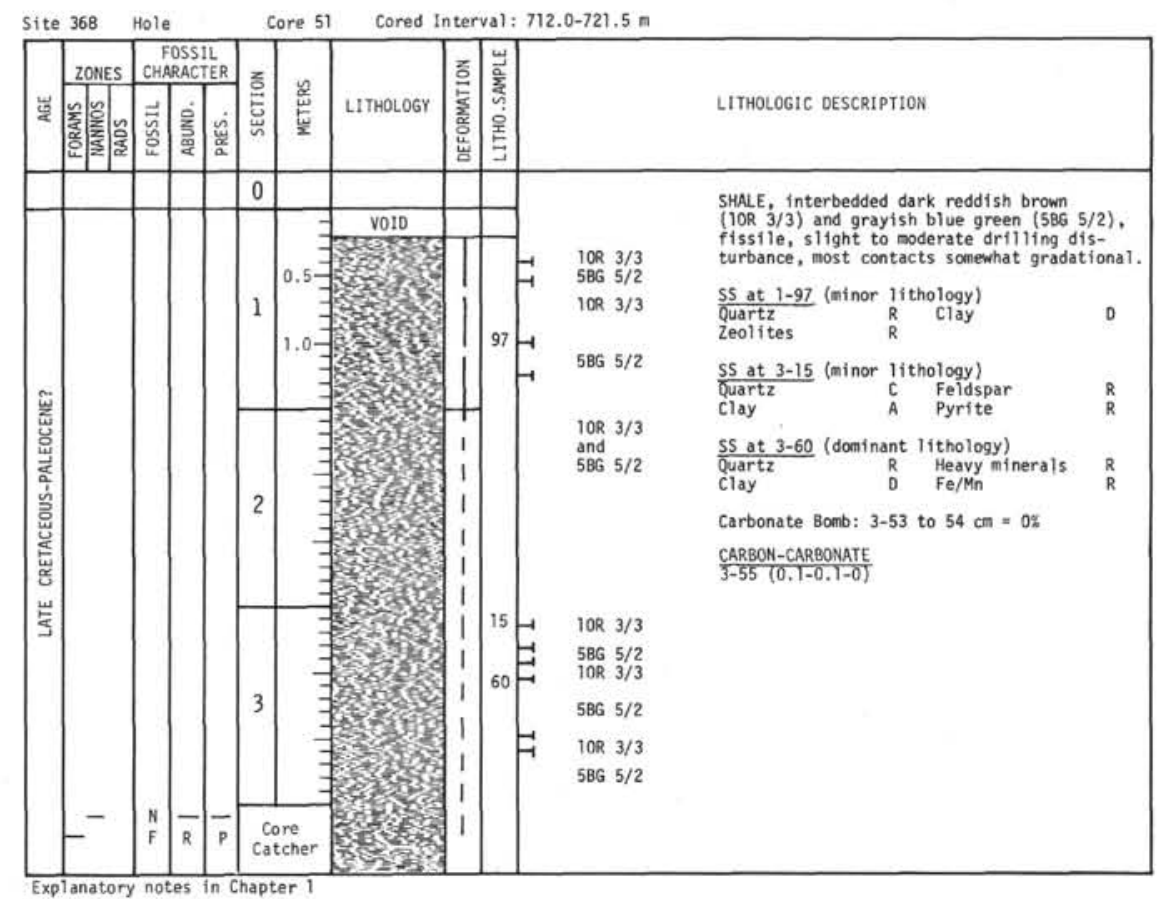

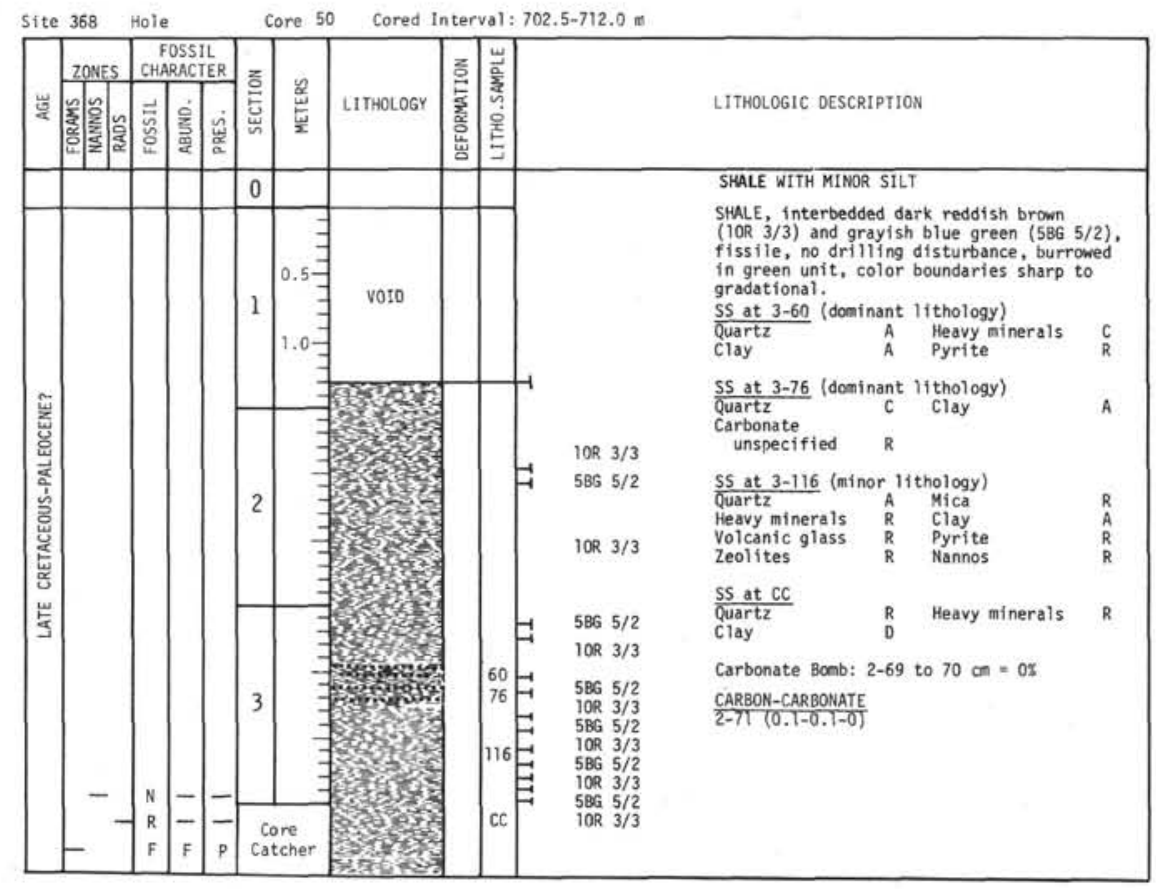




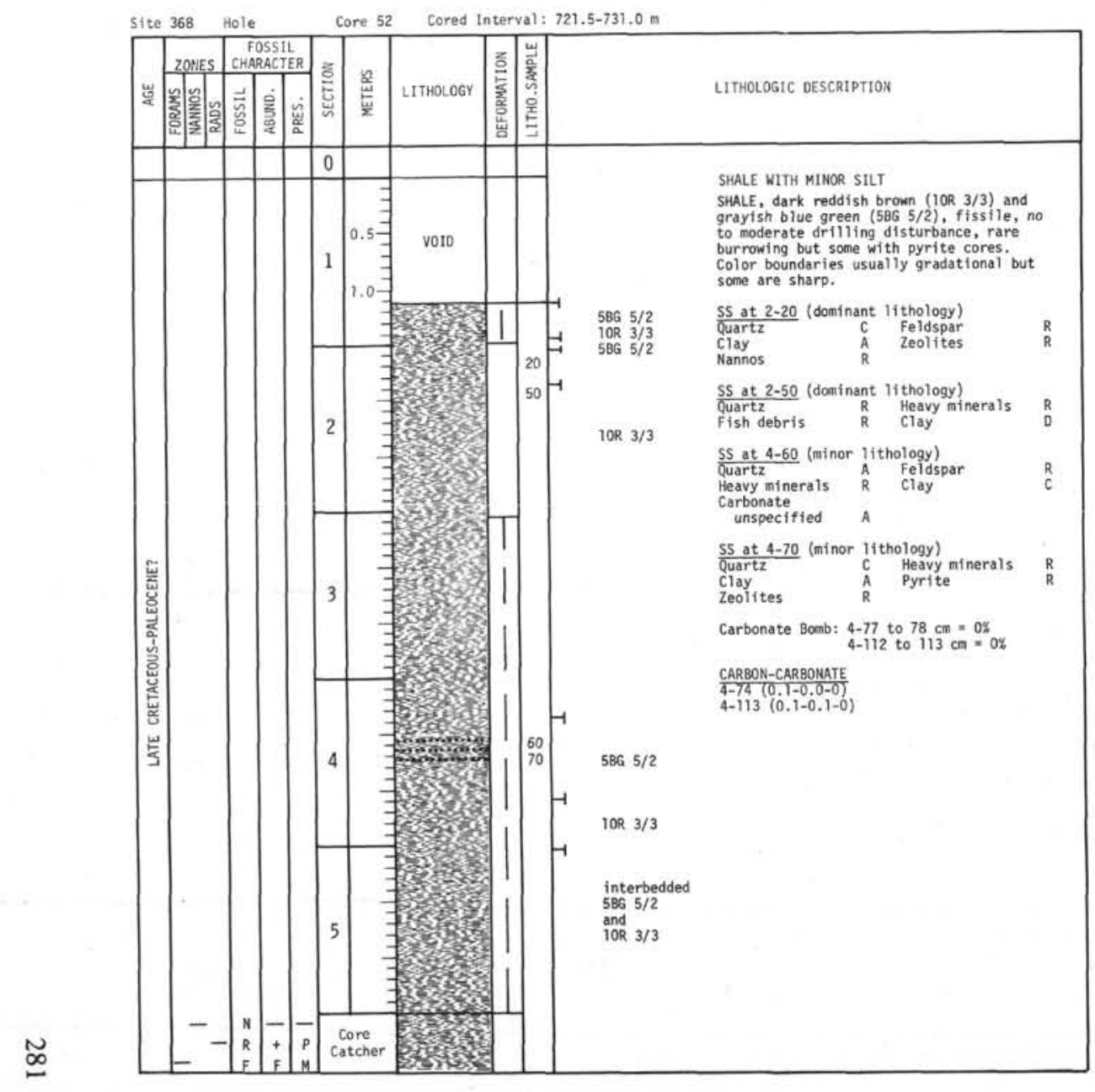

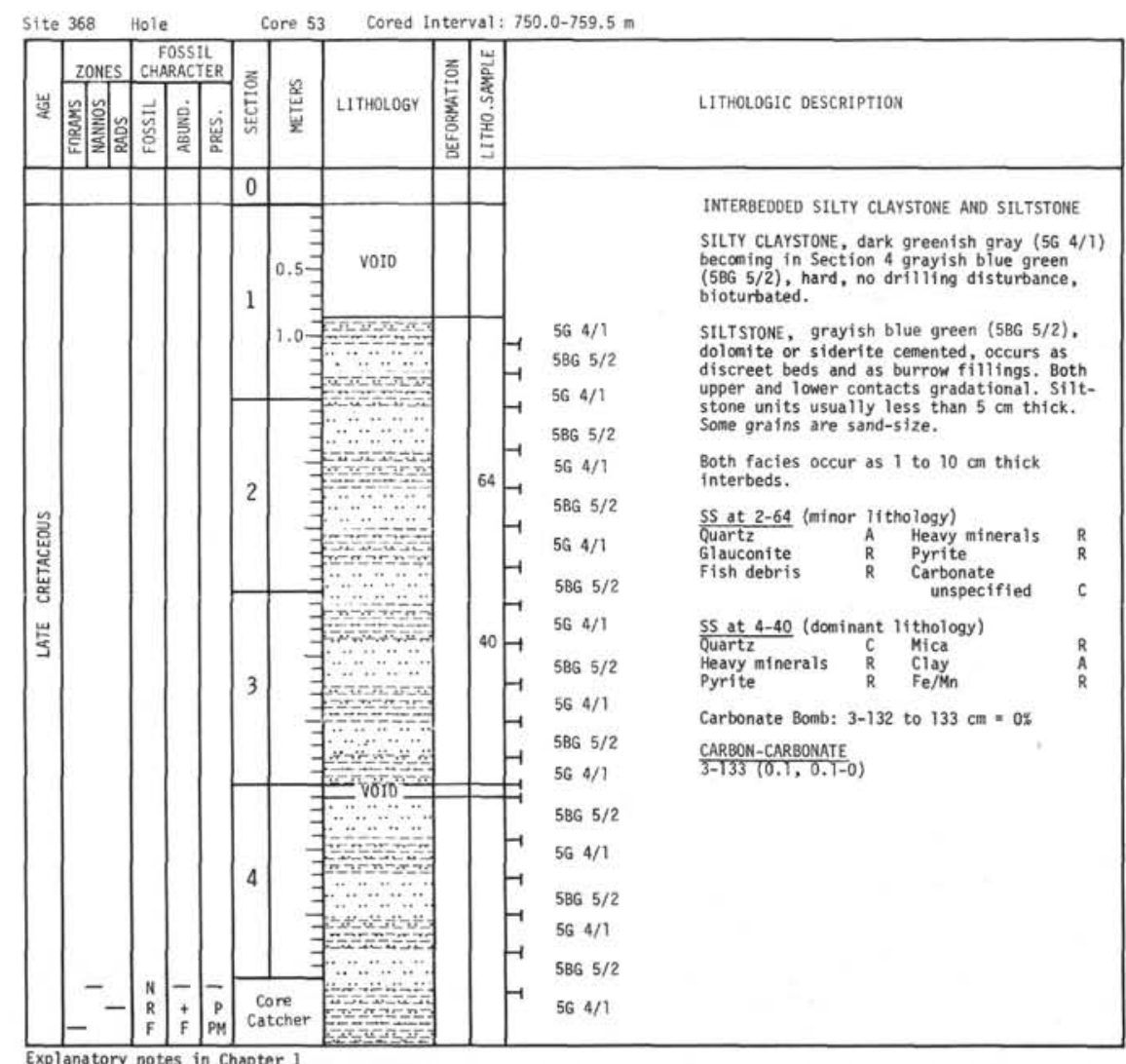




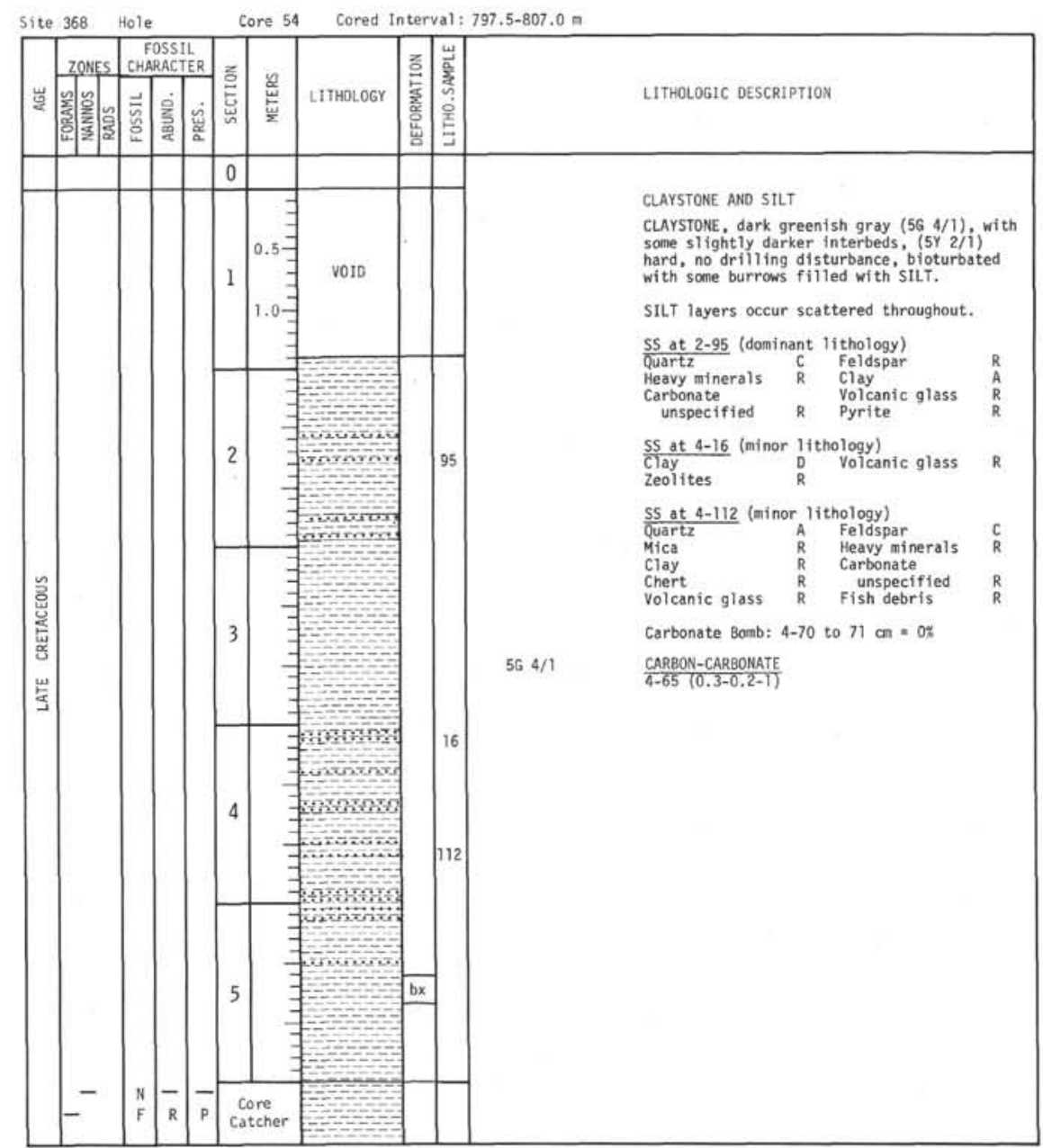

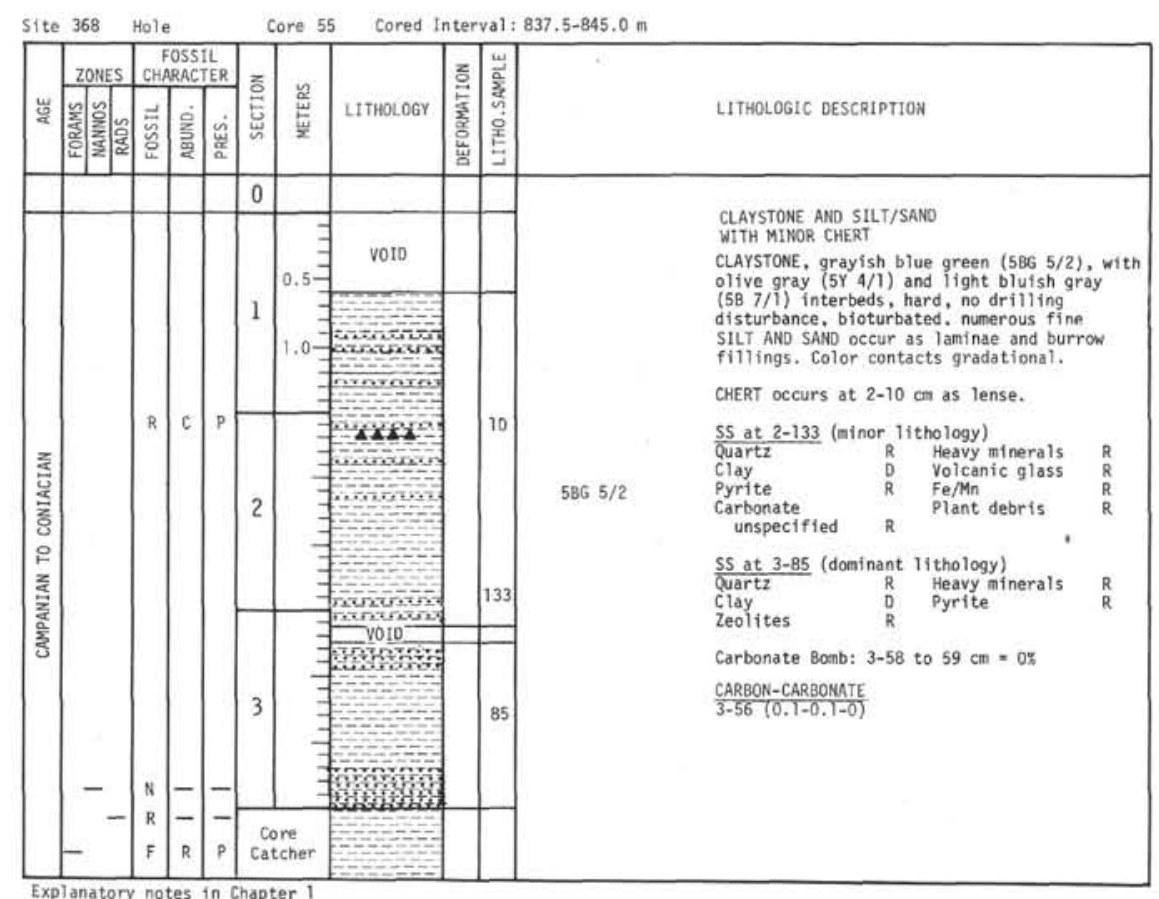




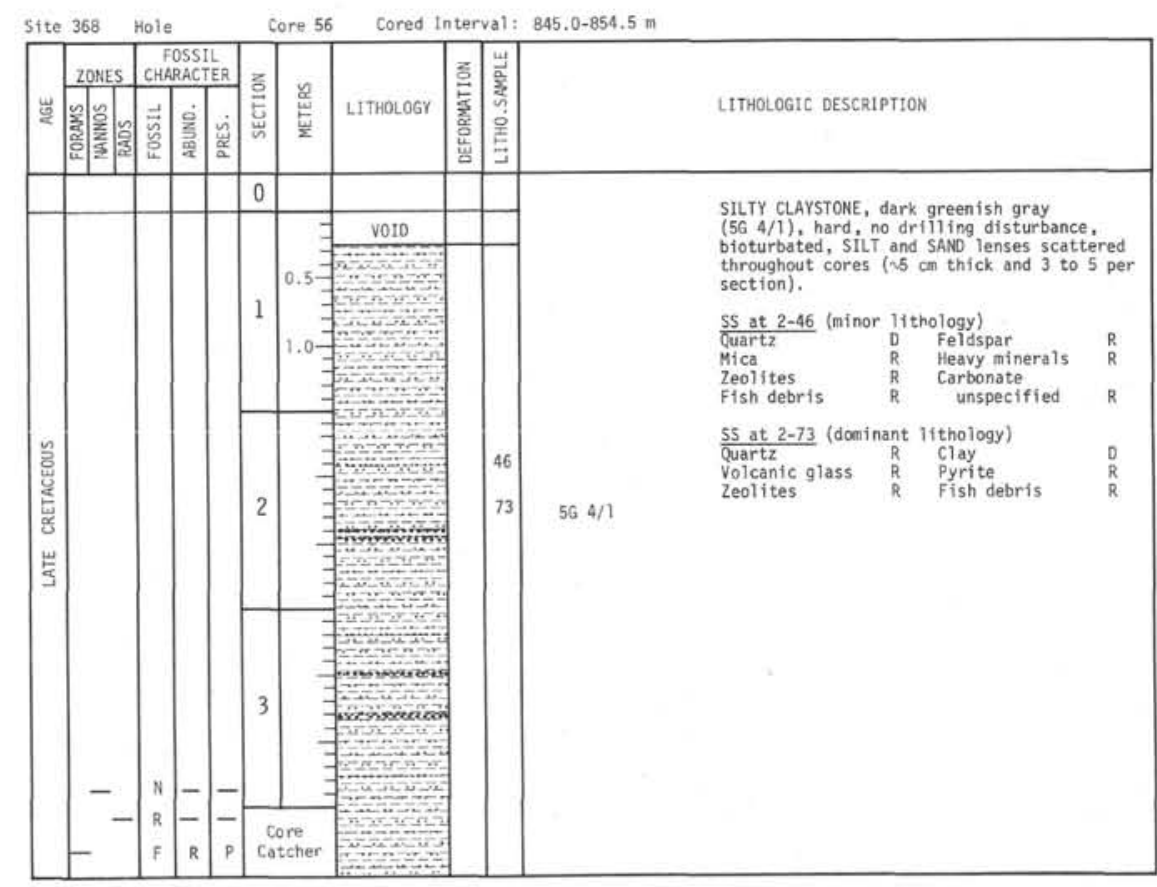

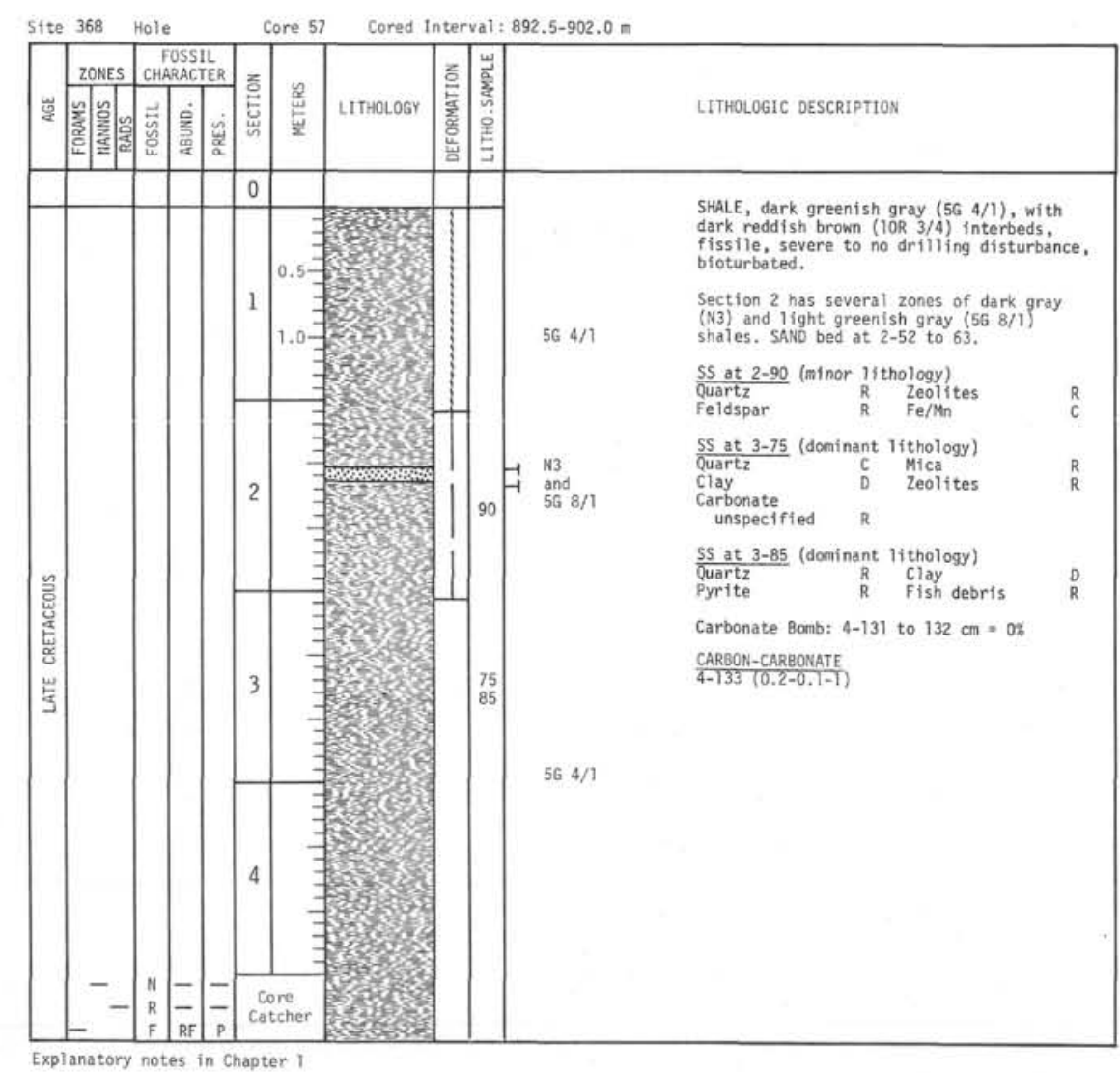

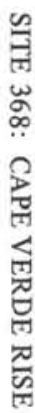




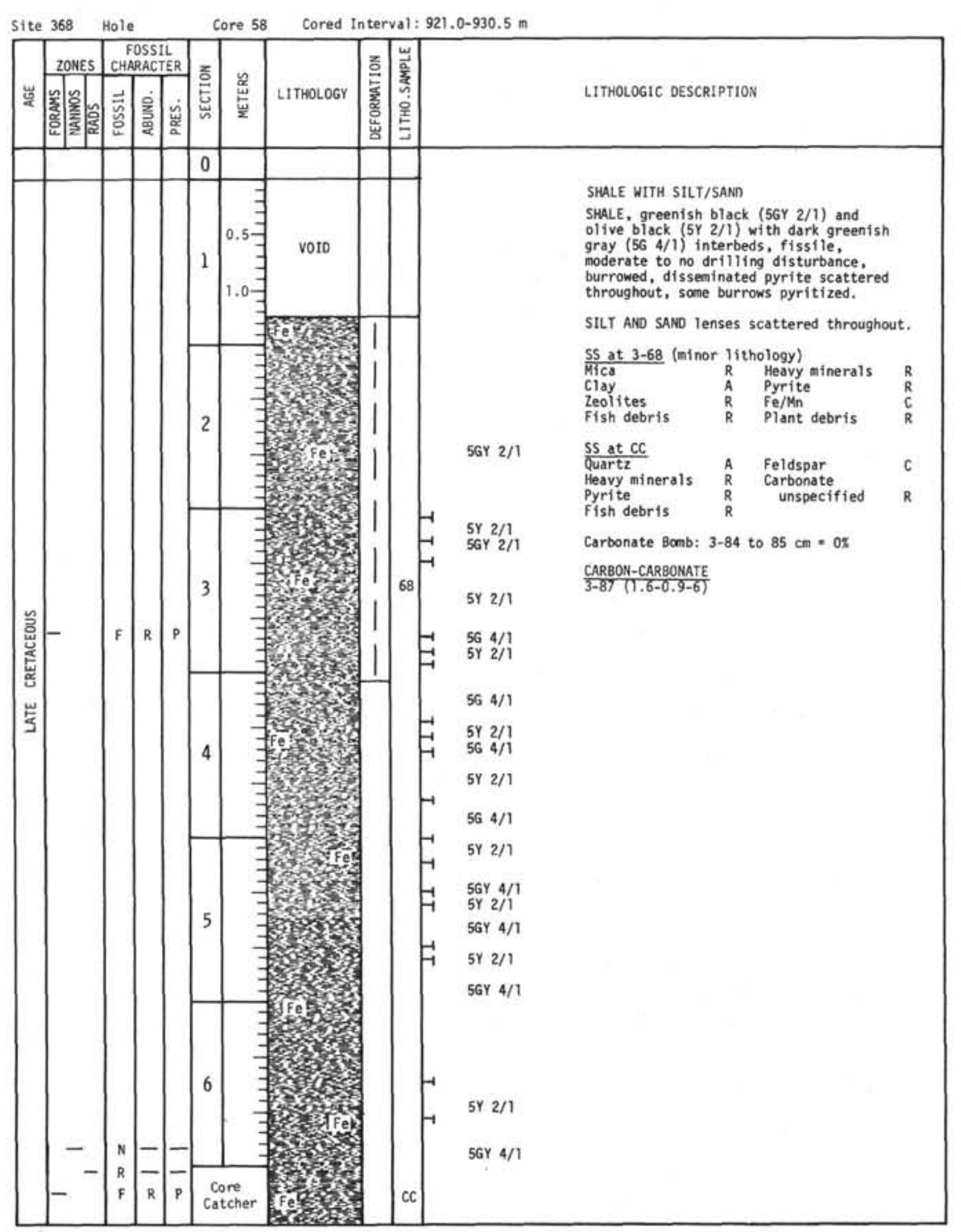

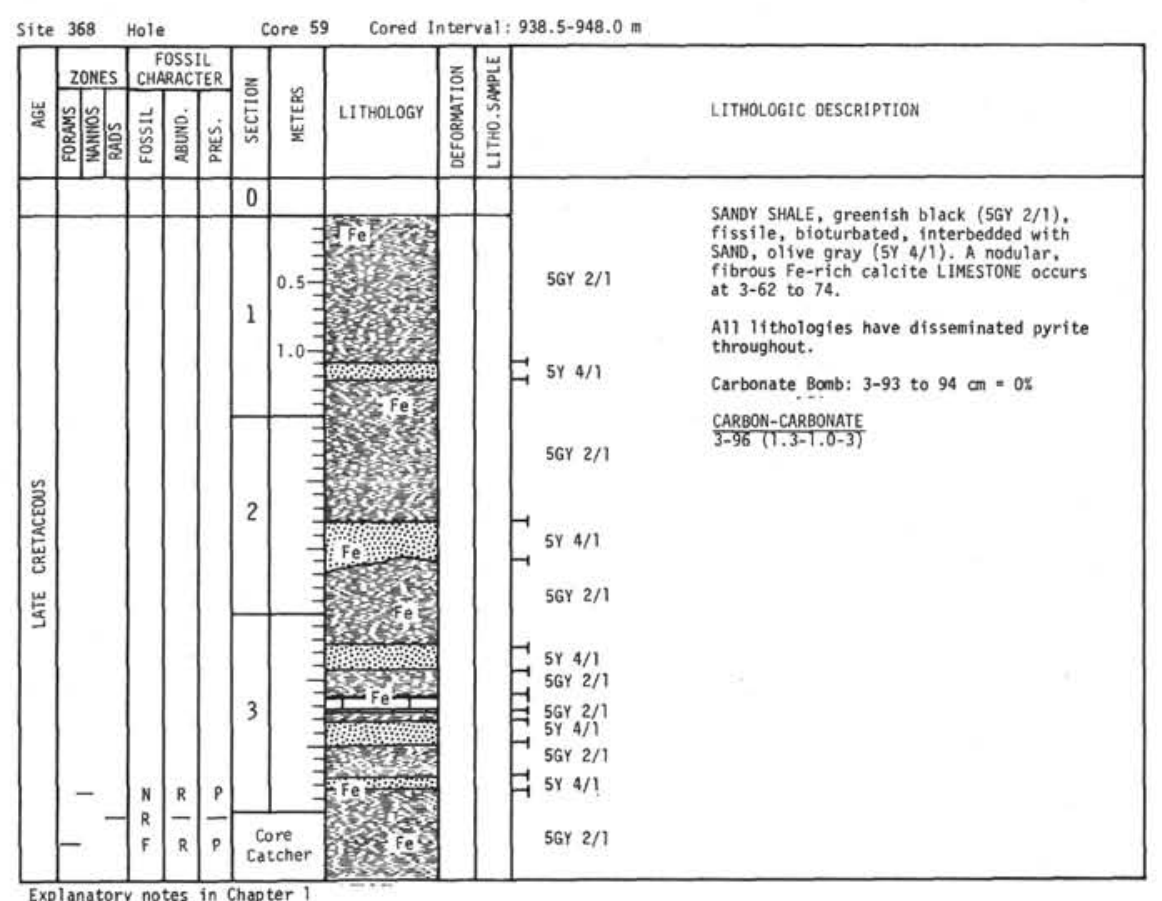



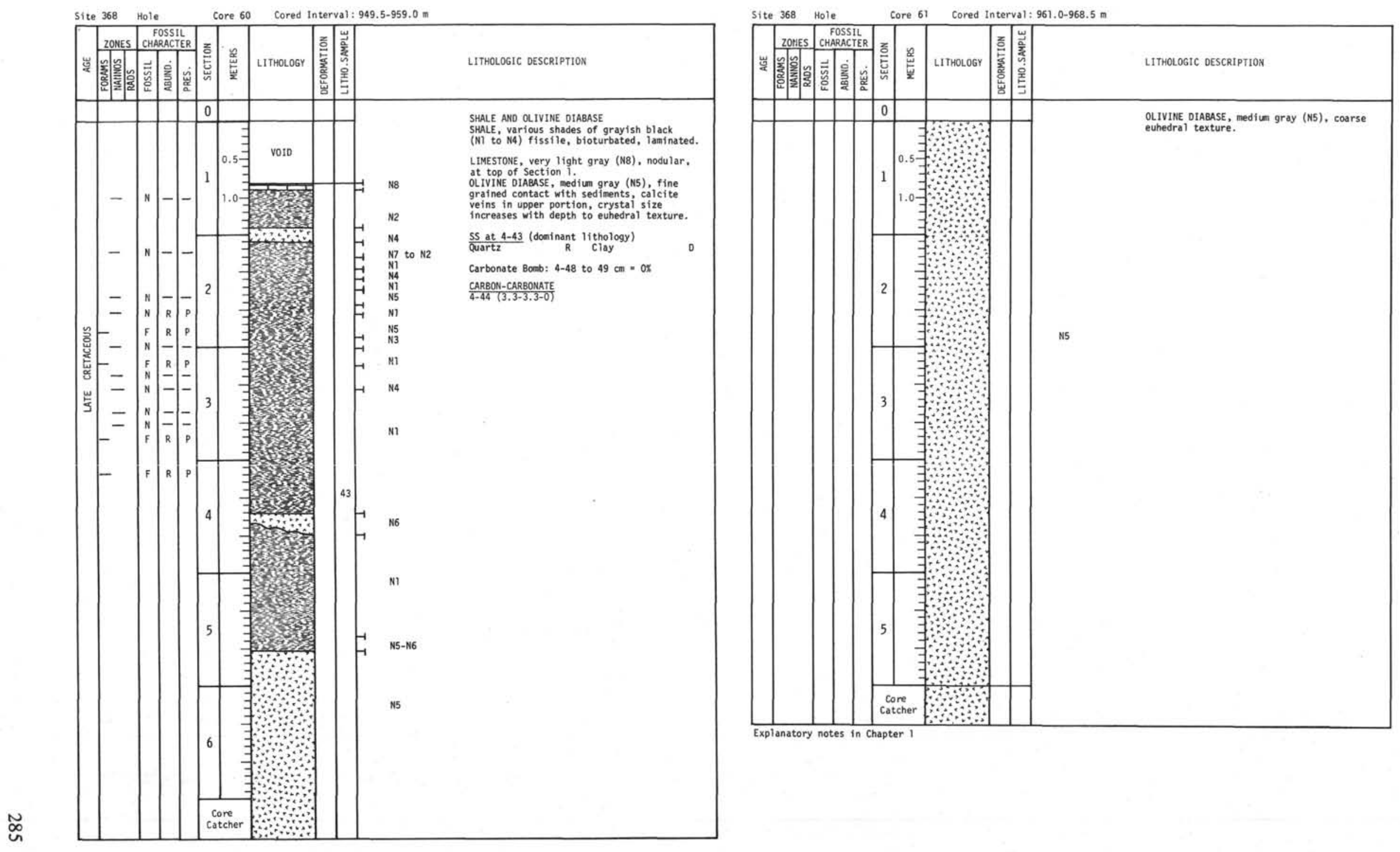


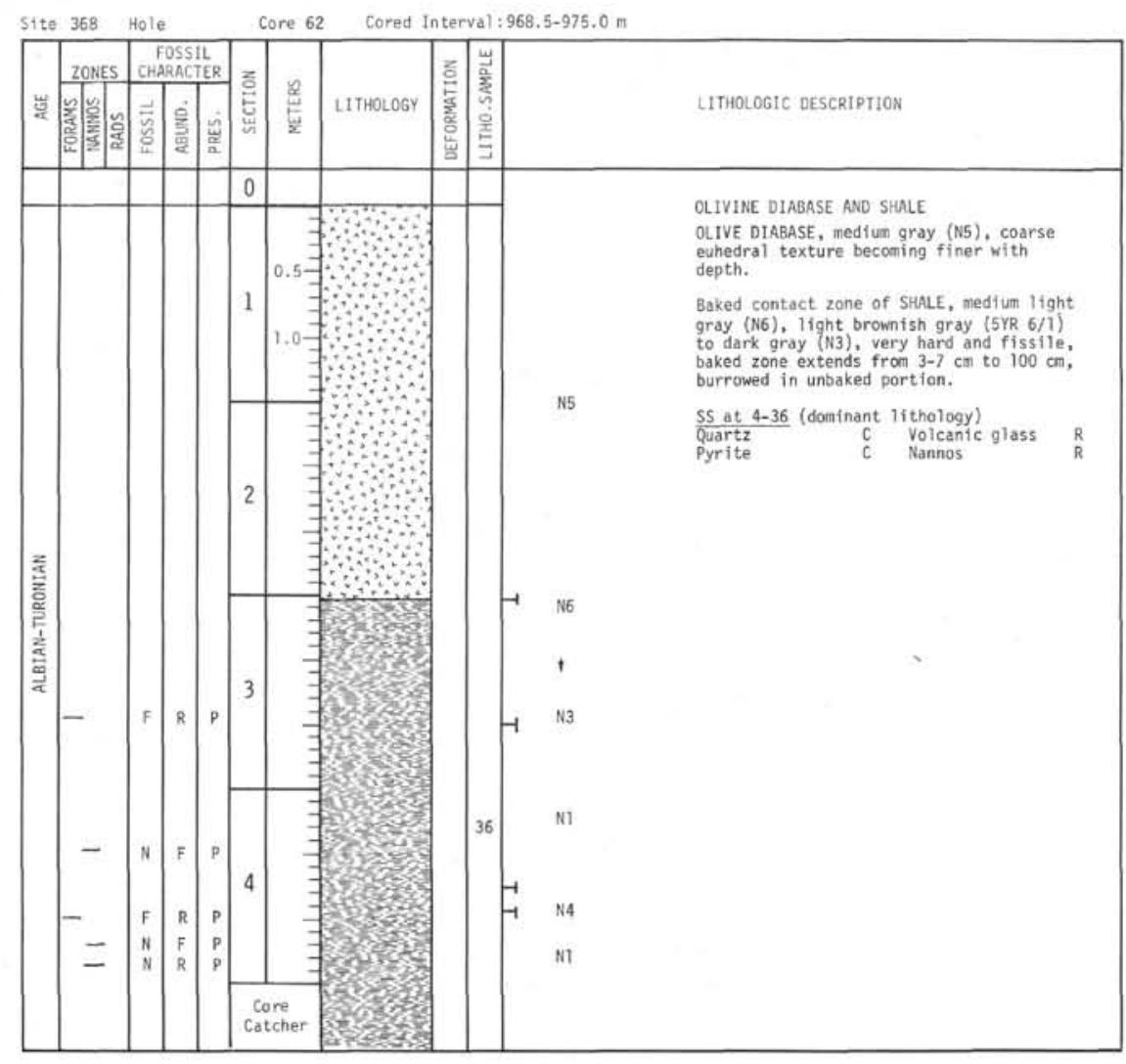

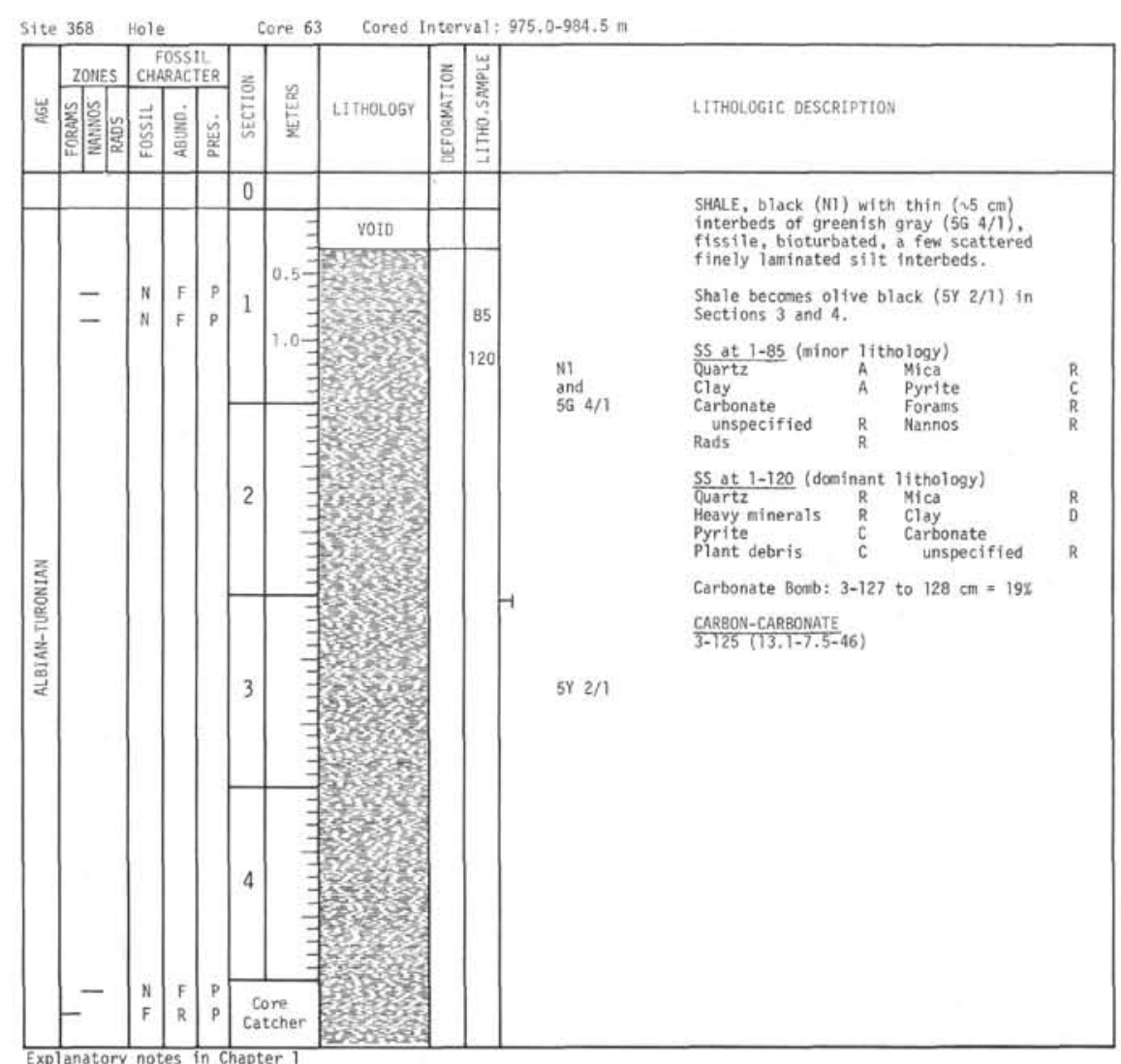




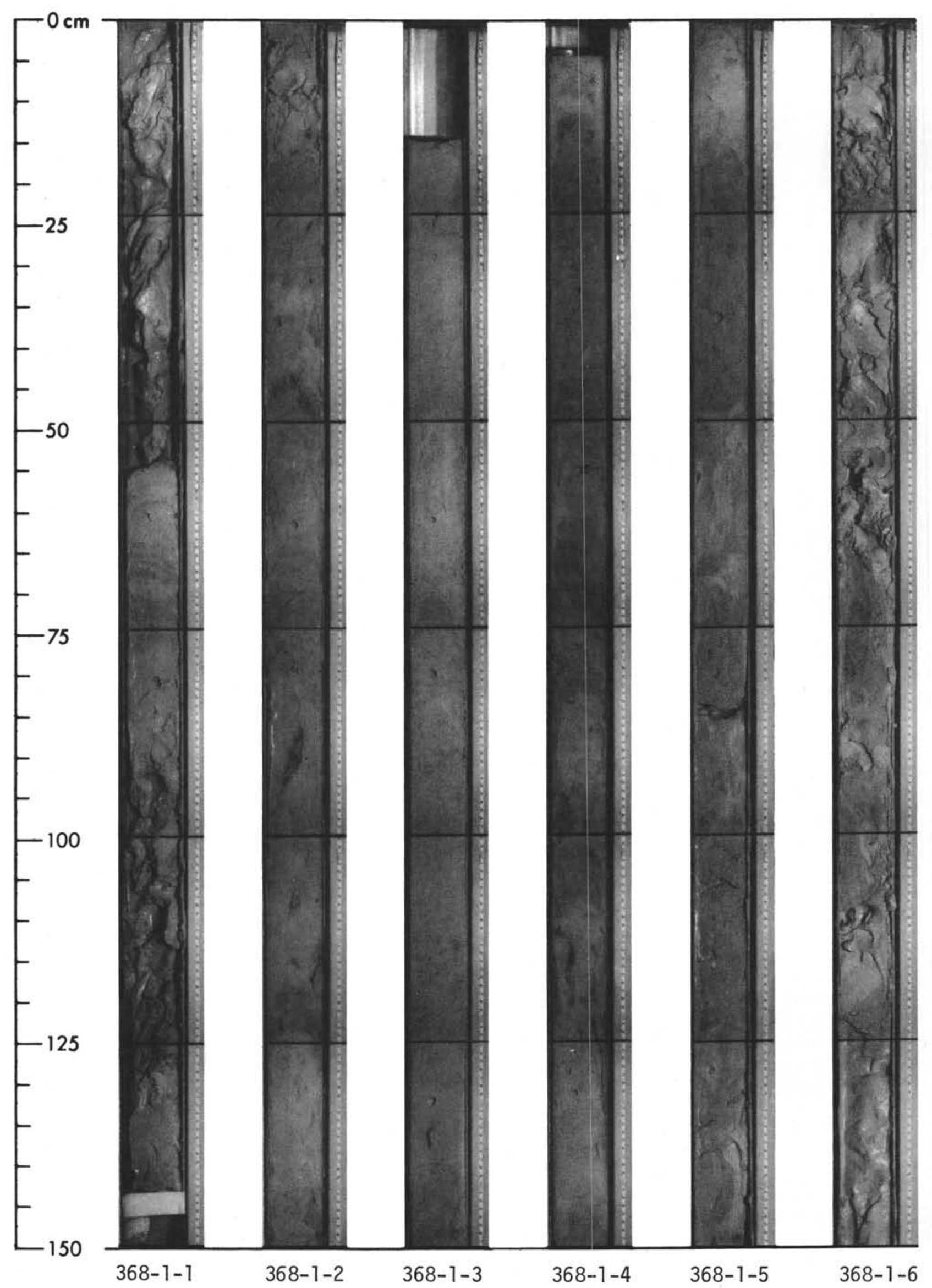


SITE 368: CAPE VERDE RISE

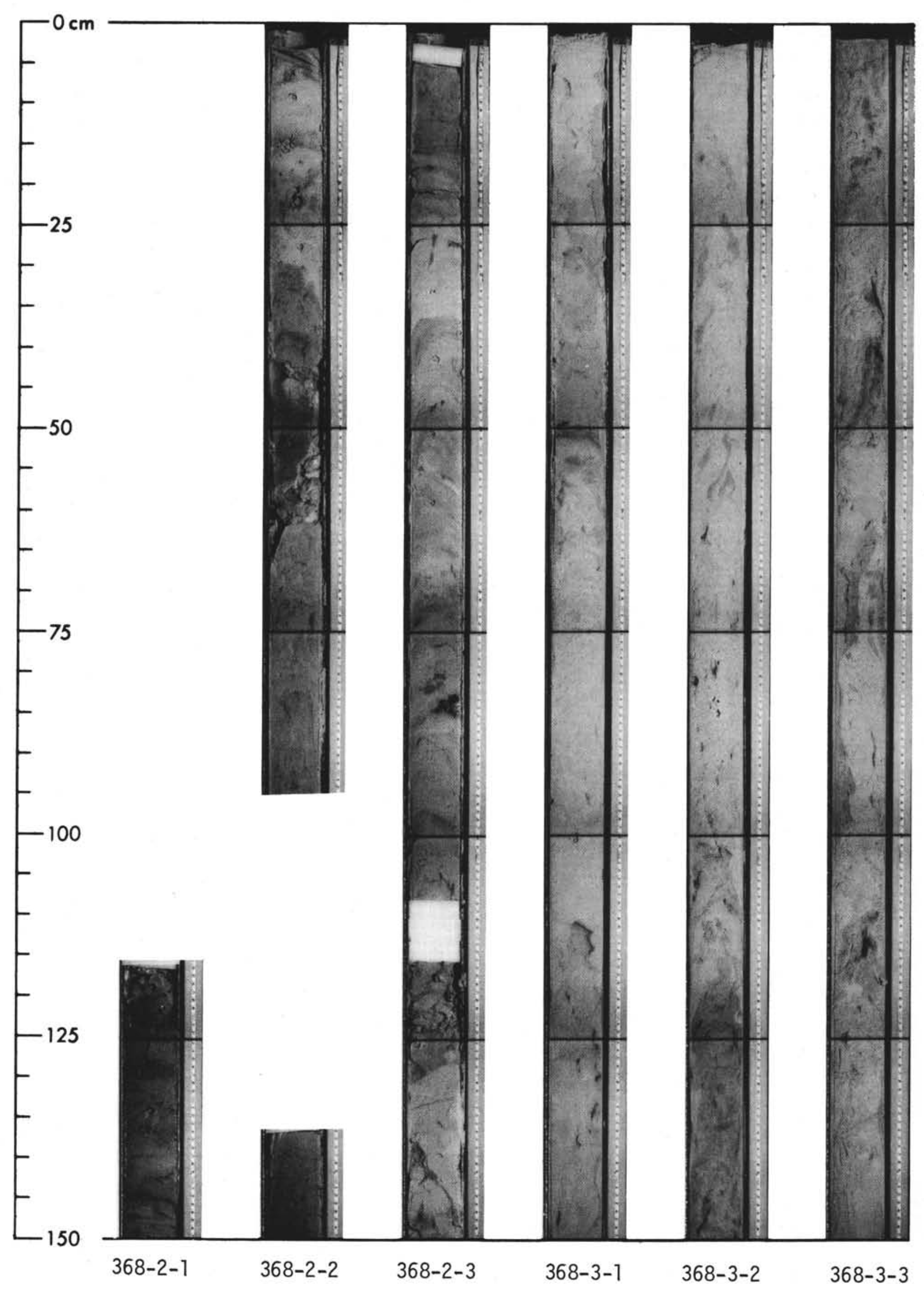




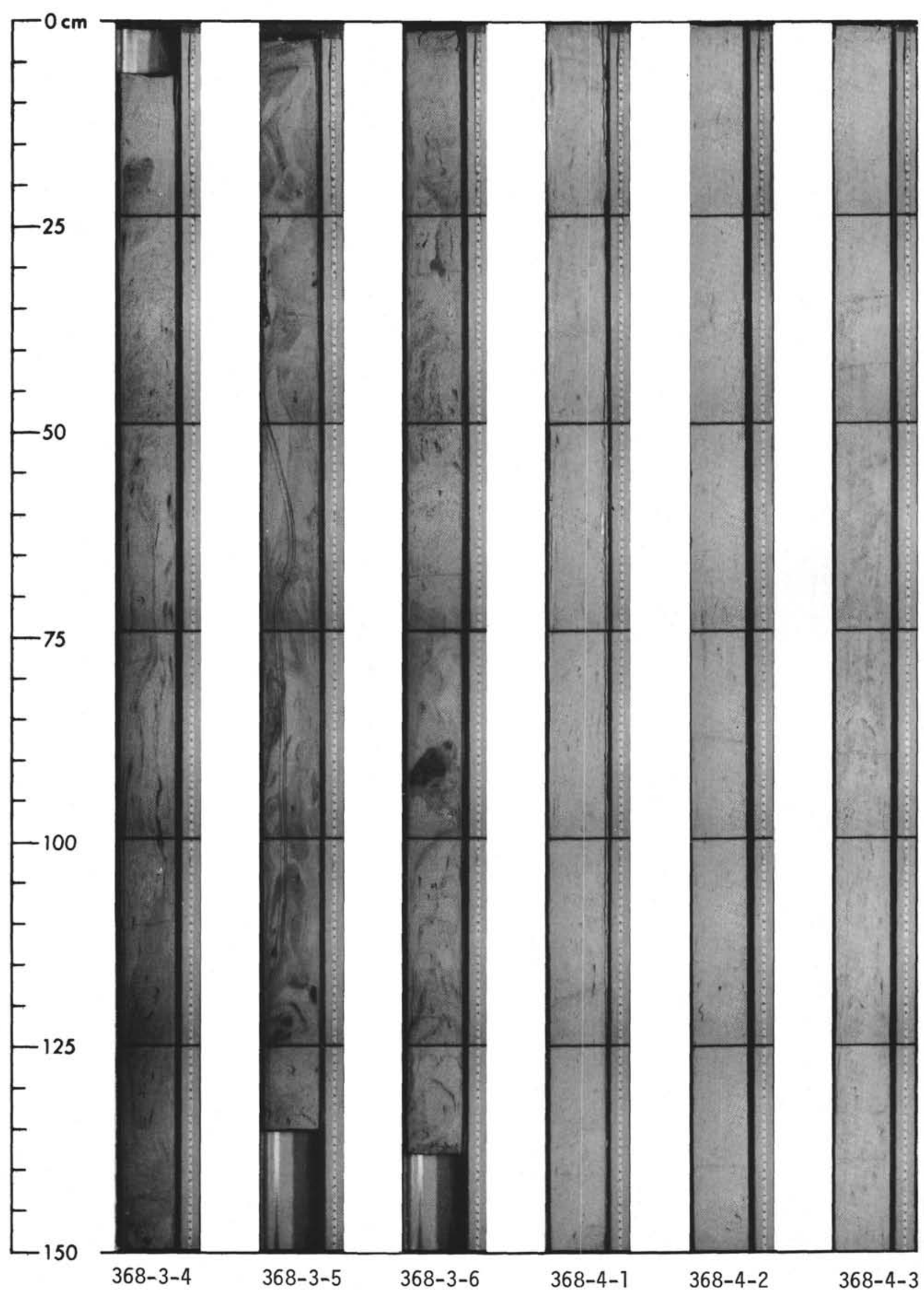


SITE 368: CAPE VERDE RISE

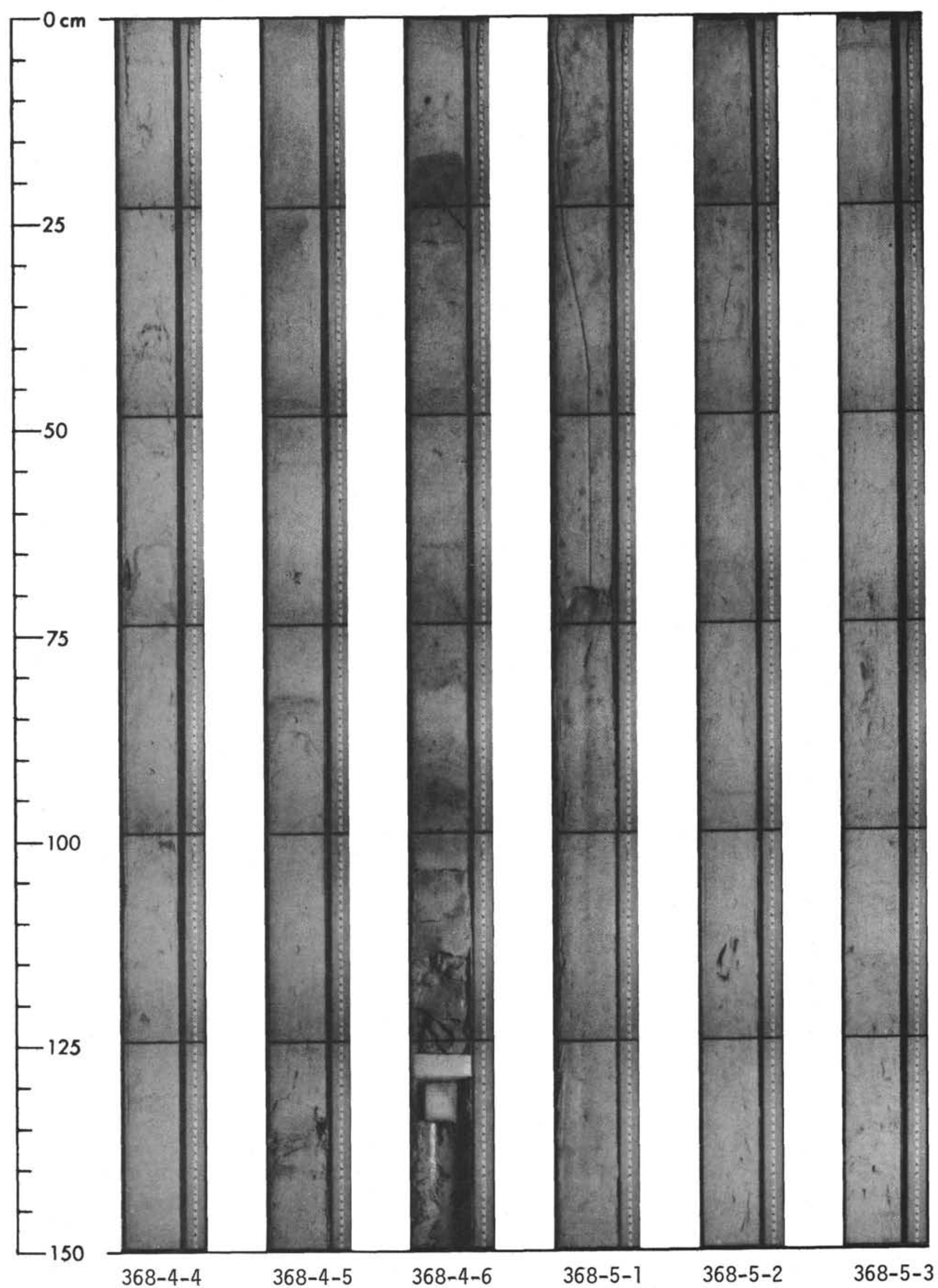




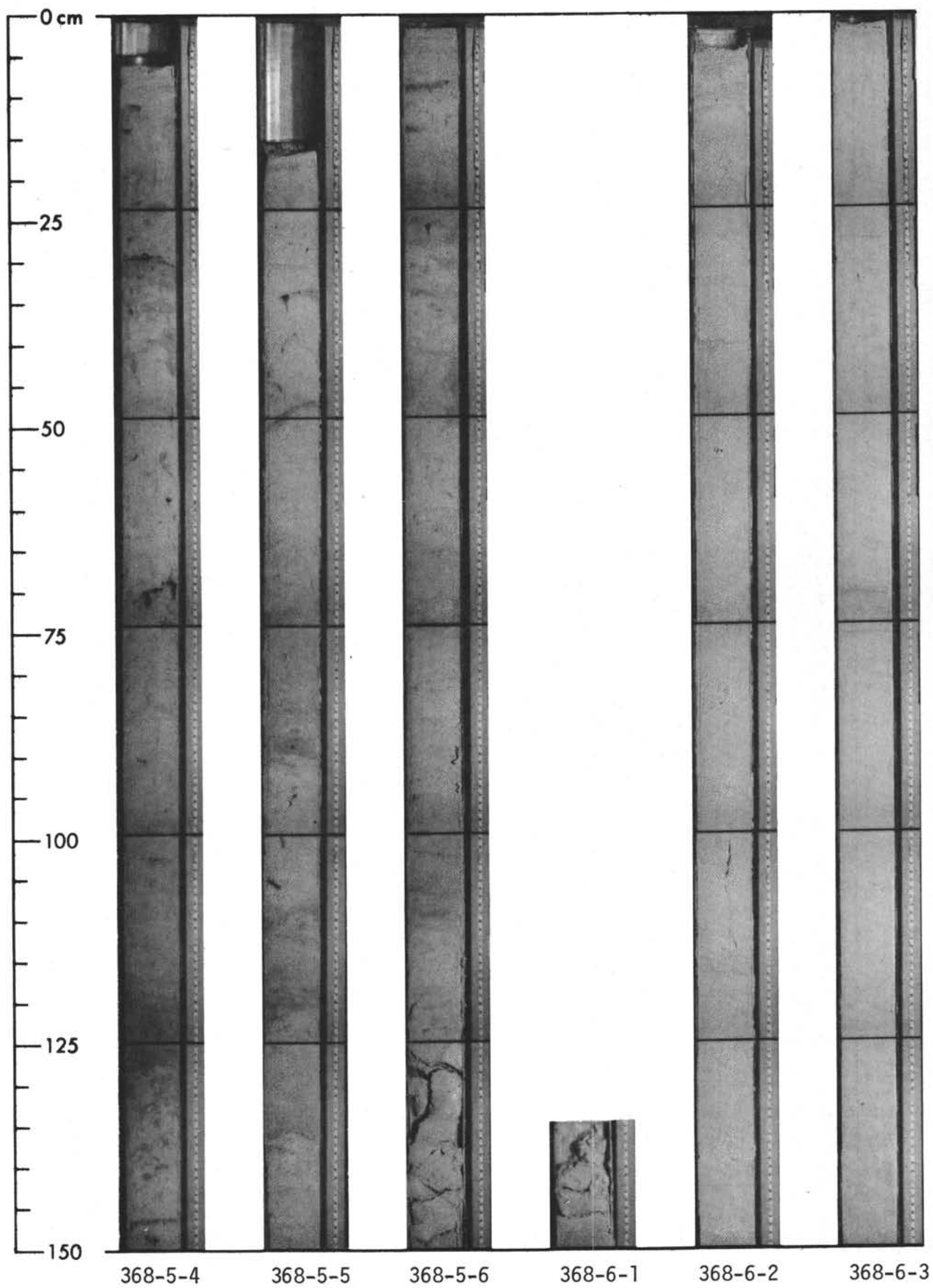




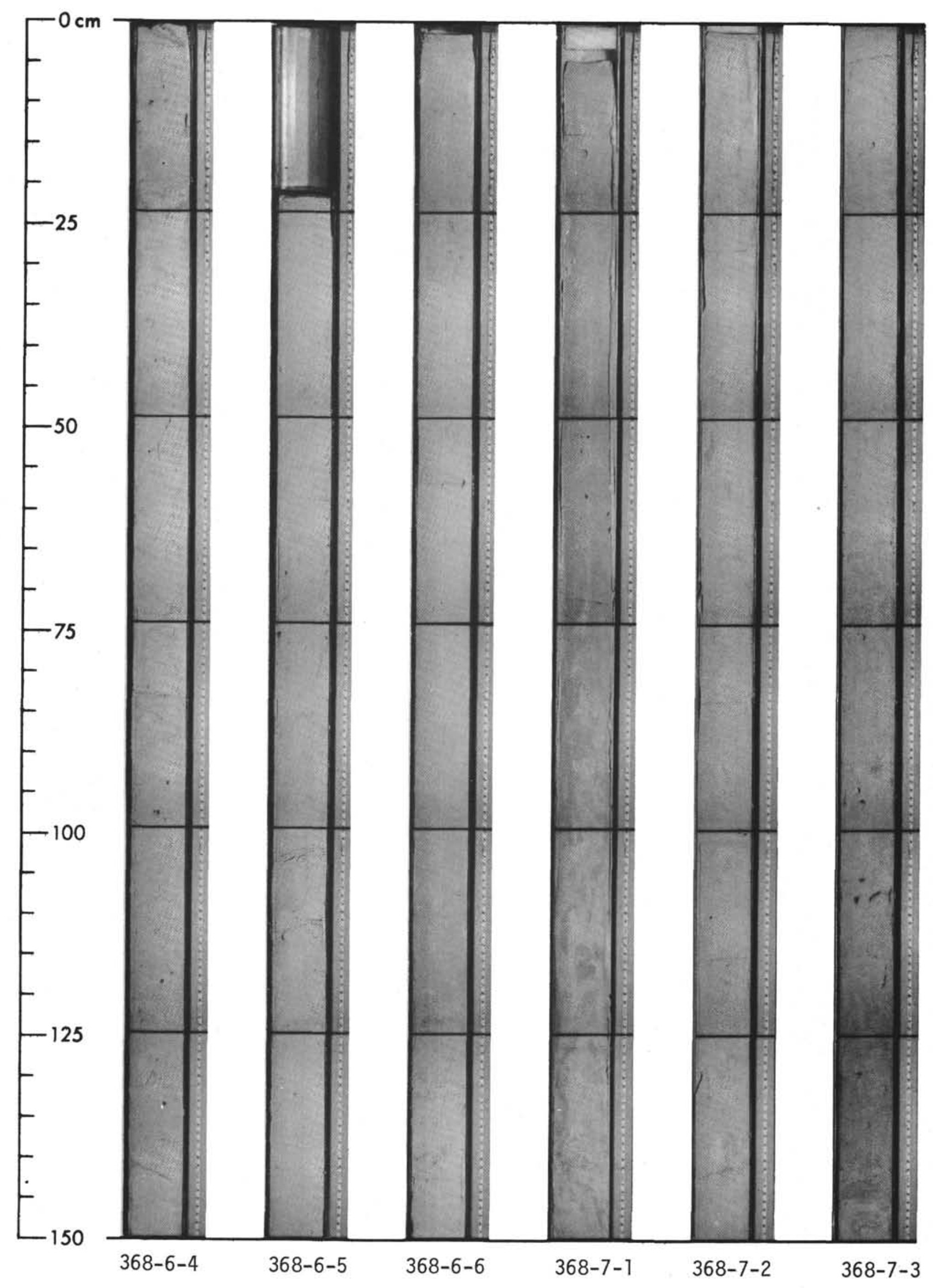


SITE 368: CAPE VERDE RISE

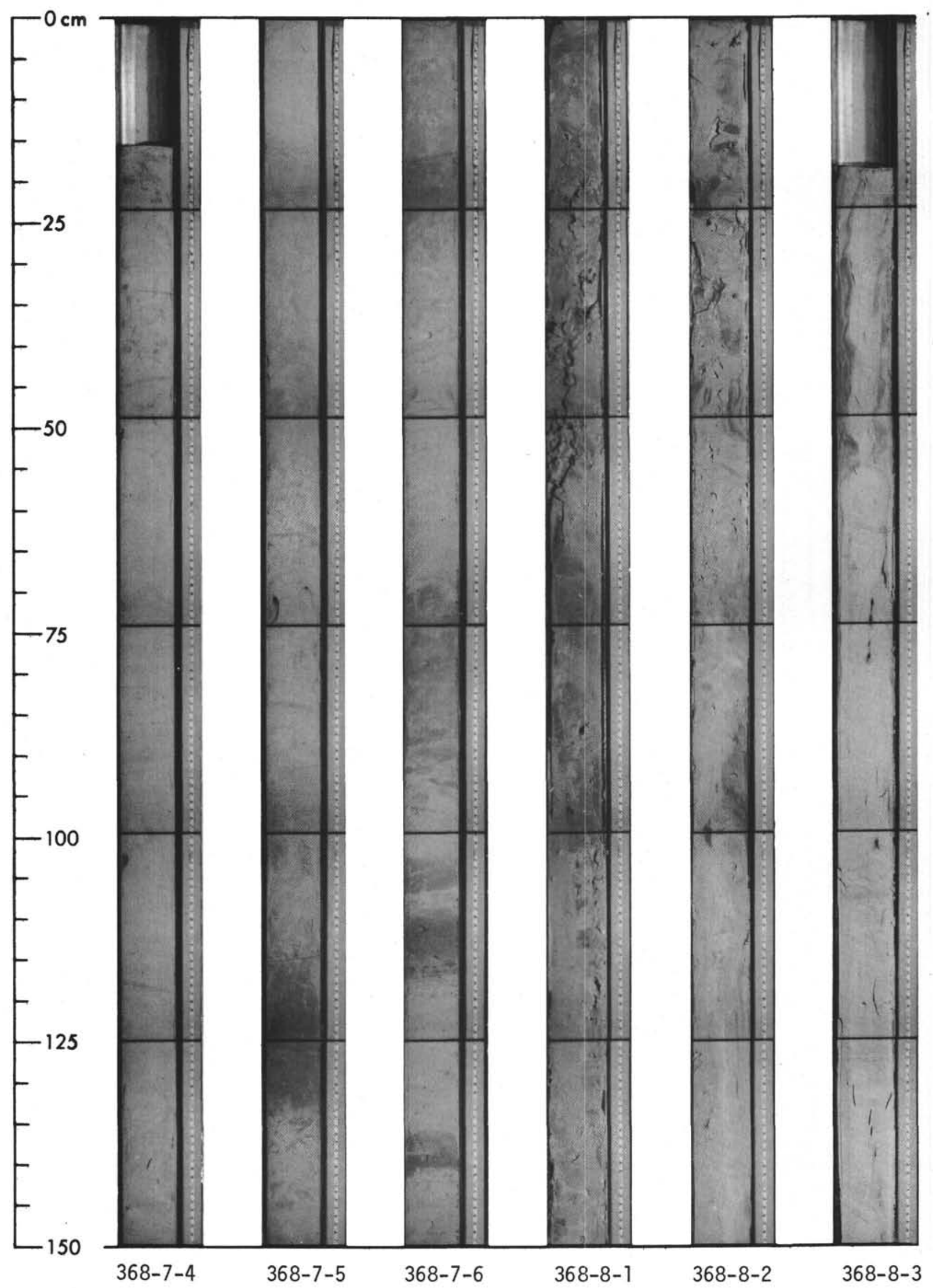




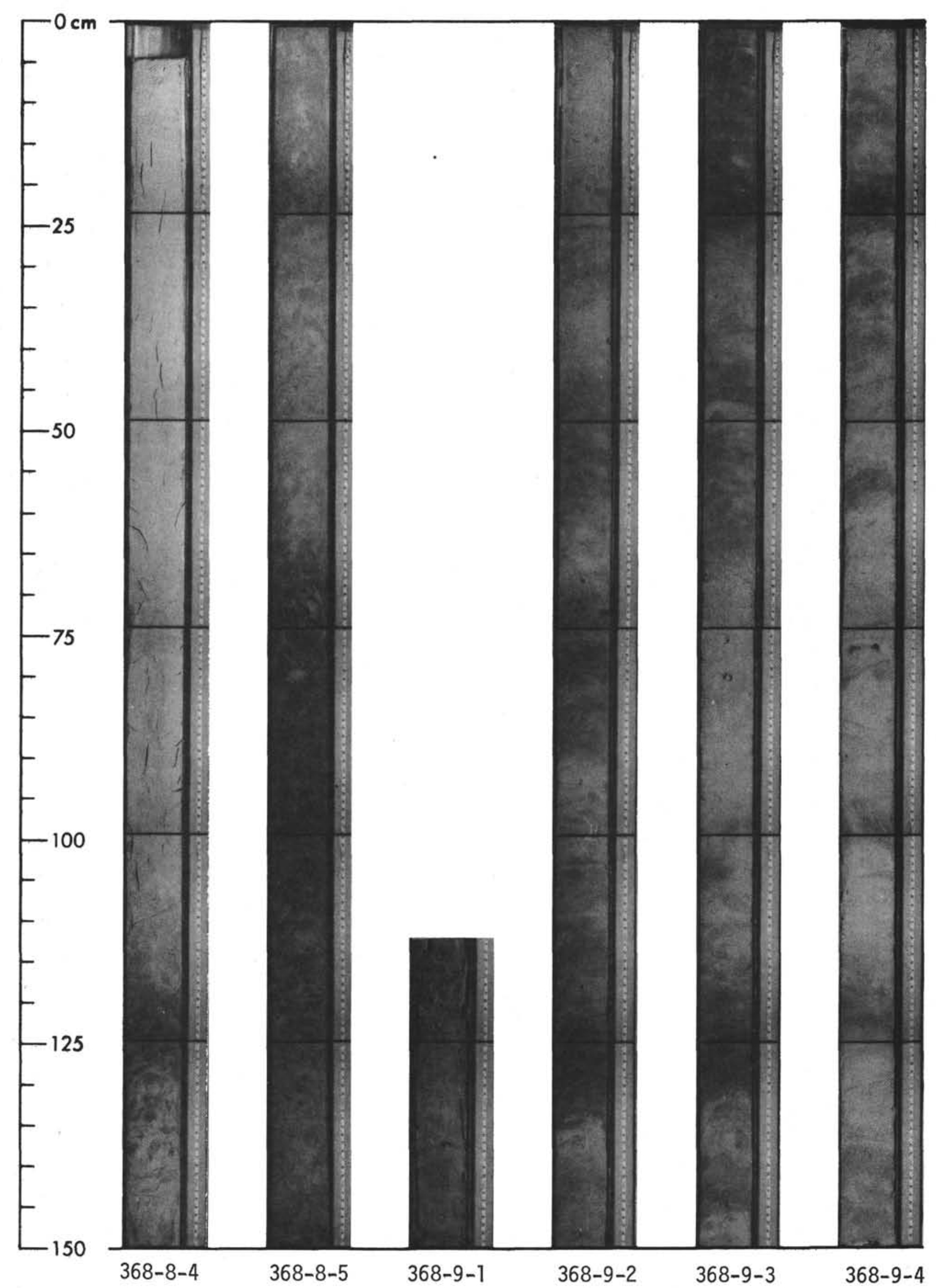




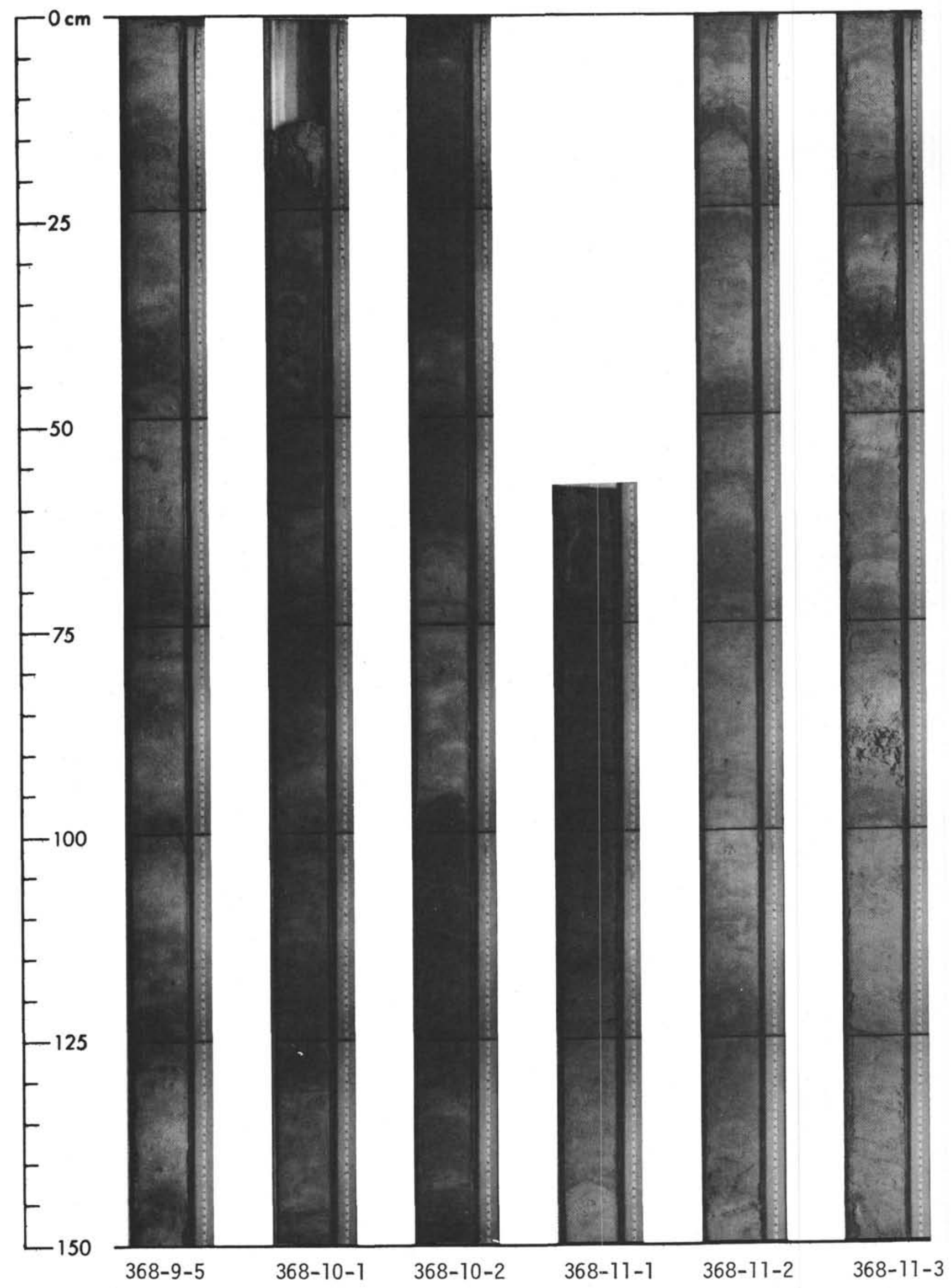




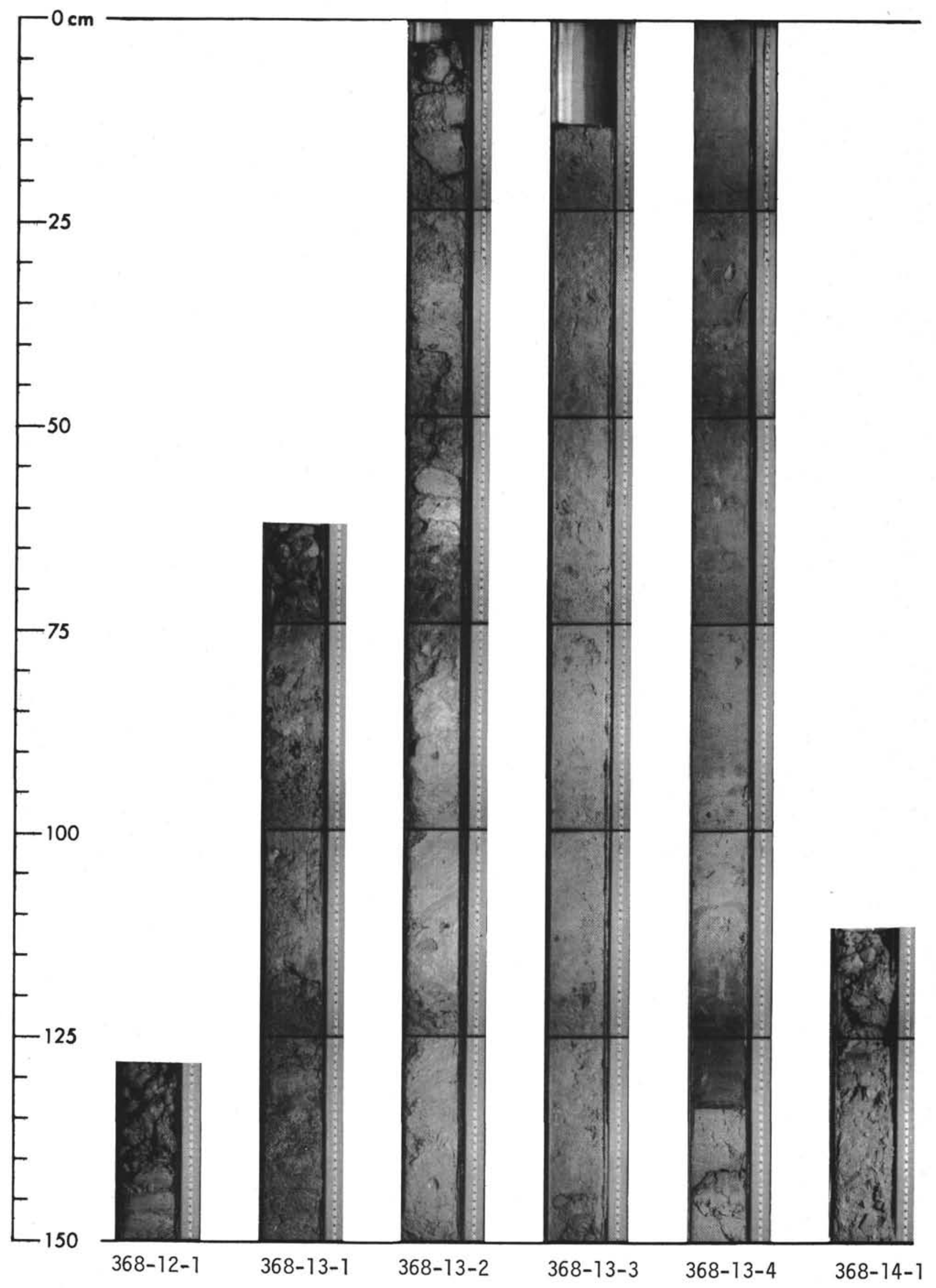




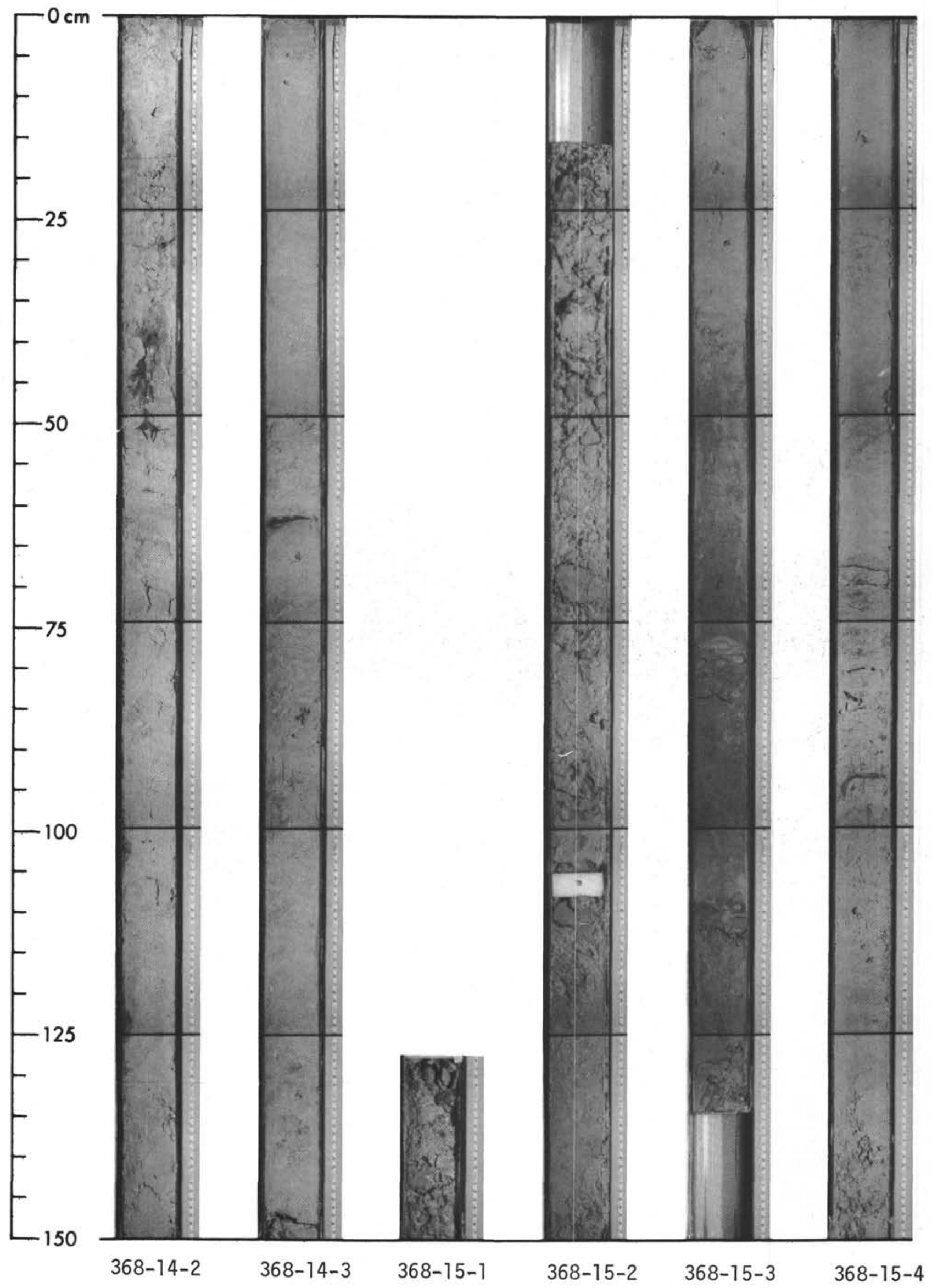




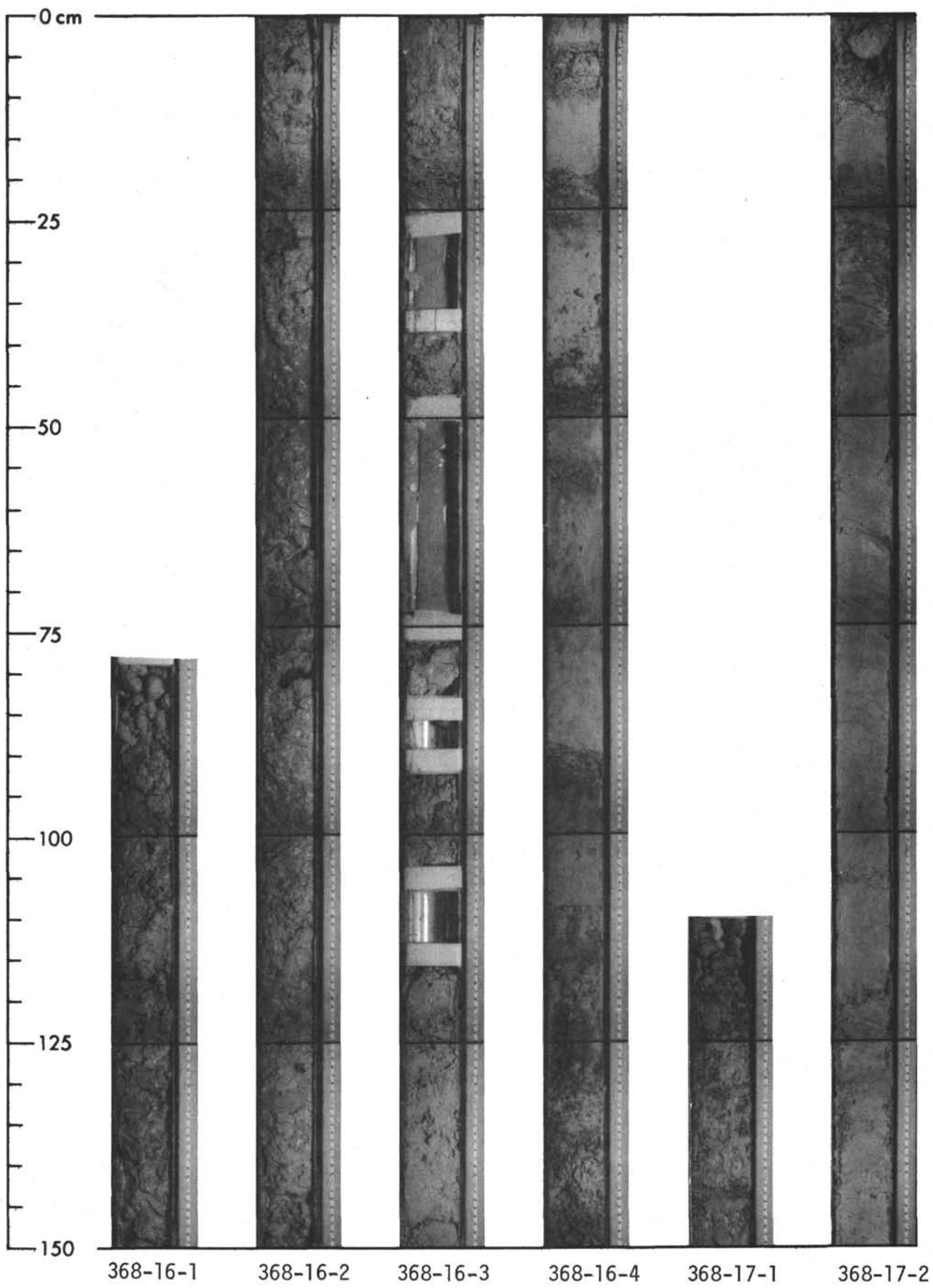




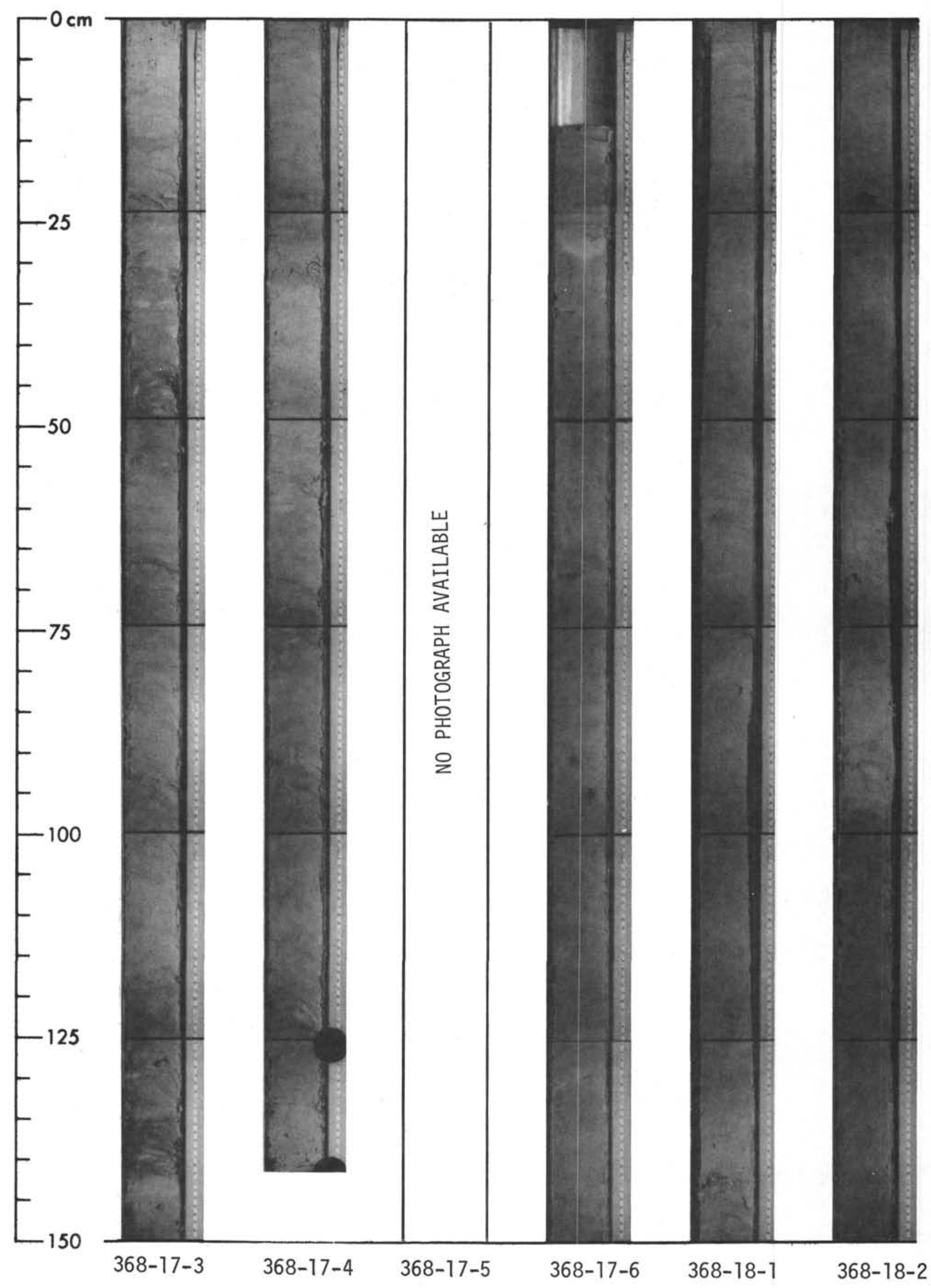




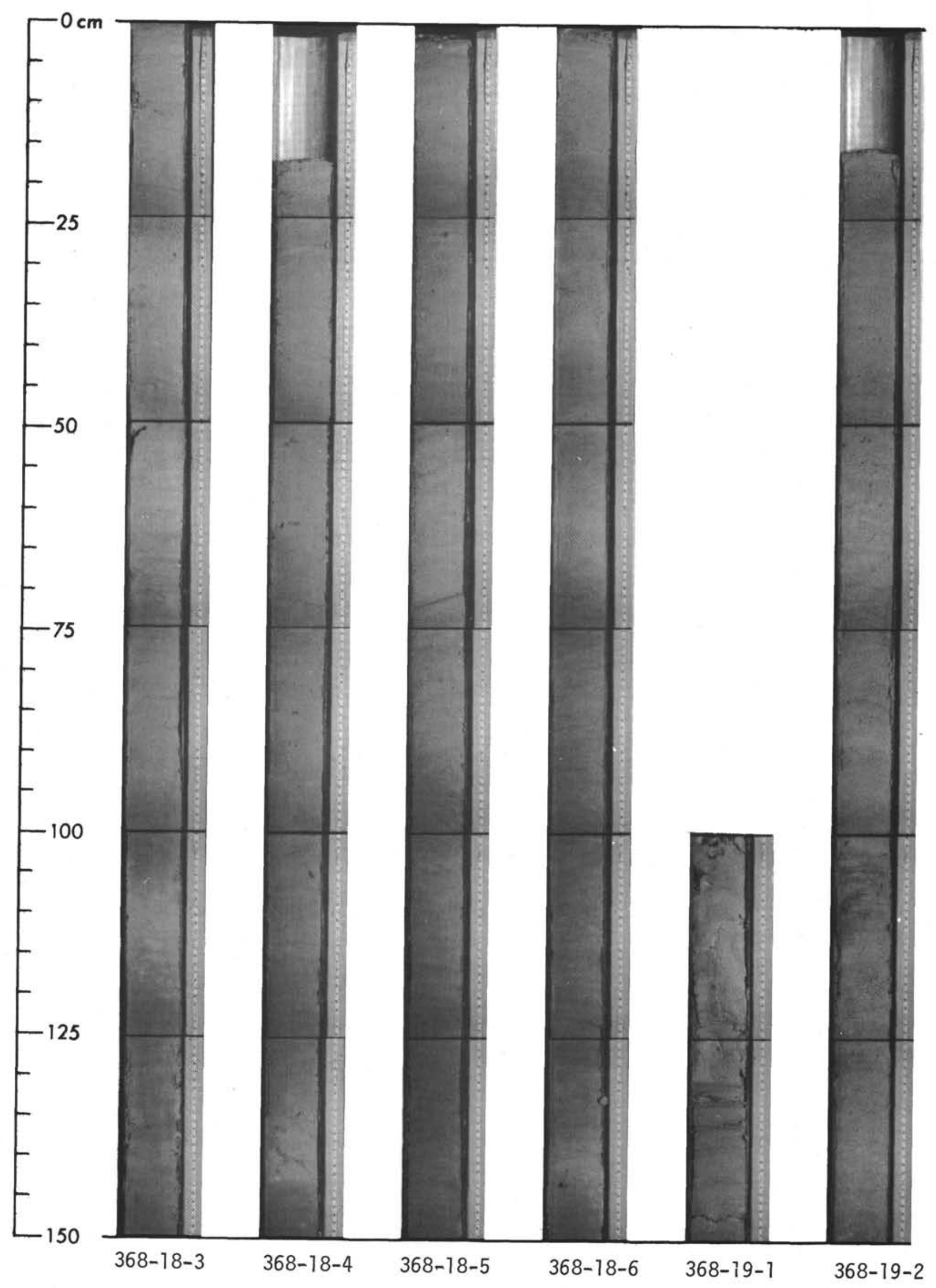


SITE 368: CAPE VERDE RISE

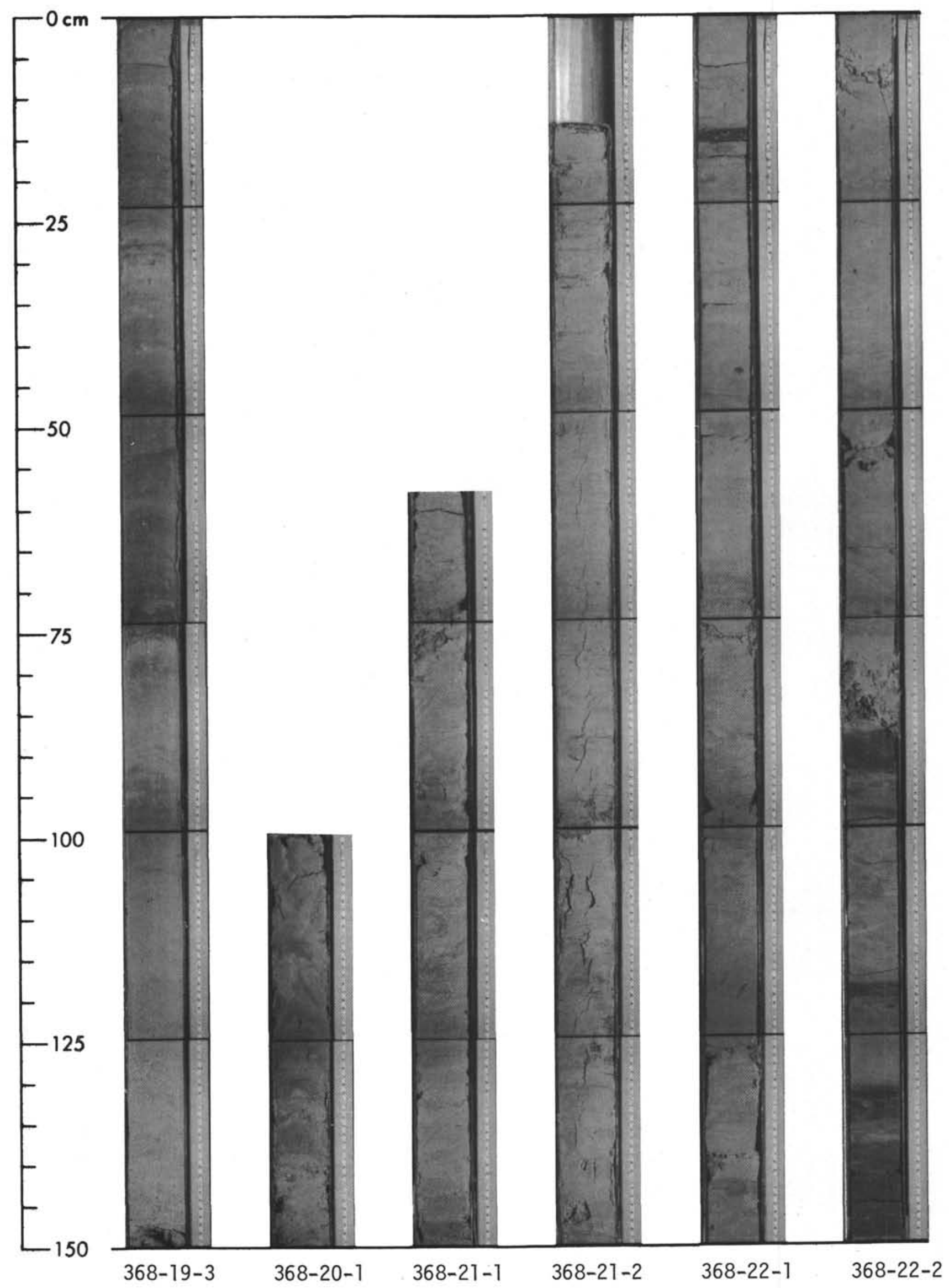


SITE 368: CAPE VERDE RISE

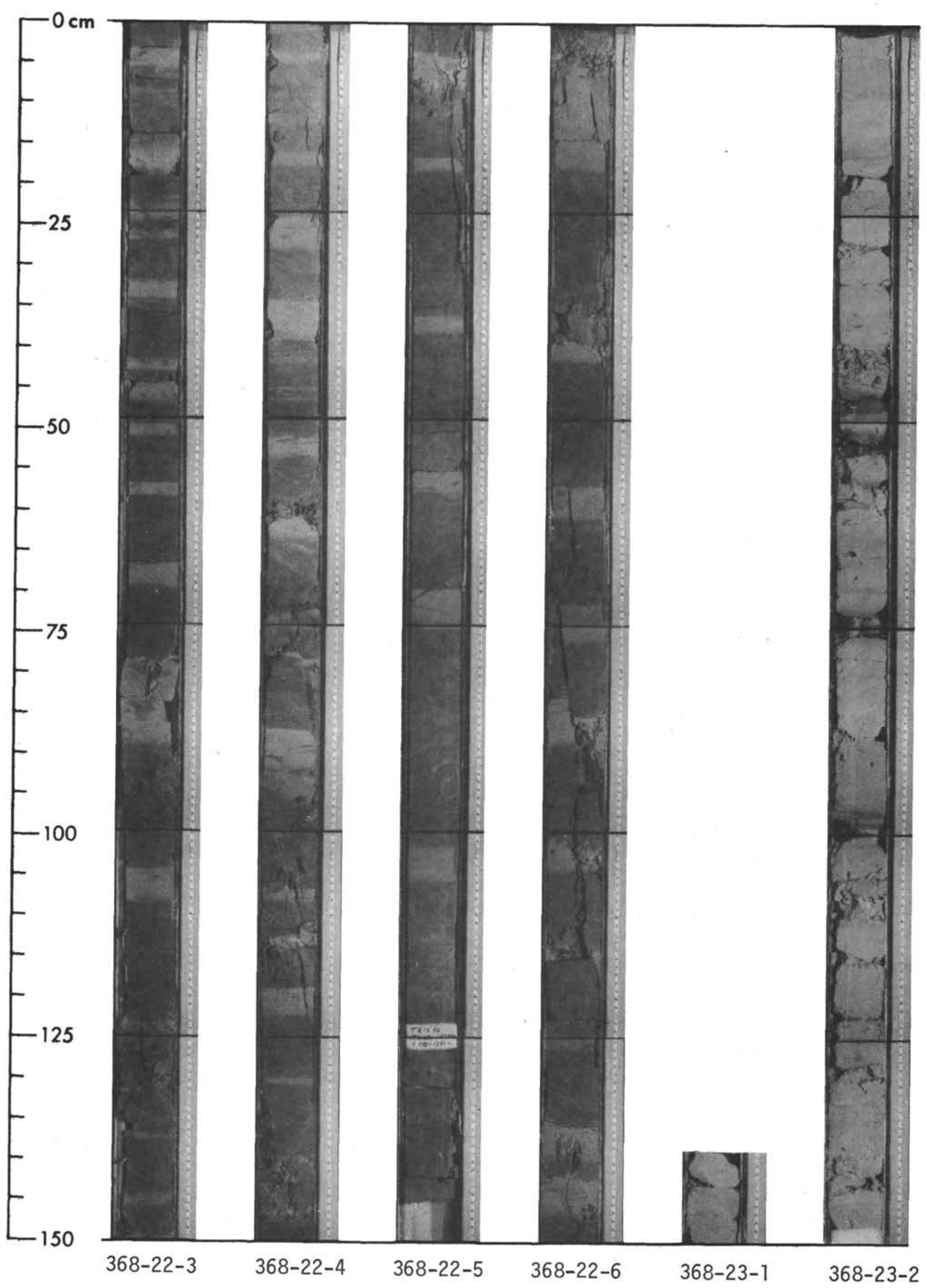




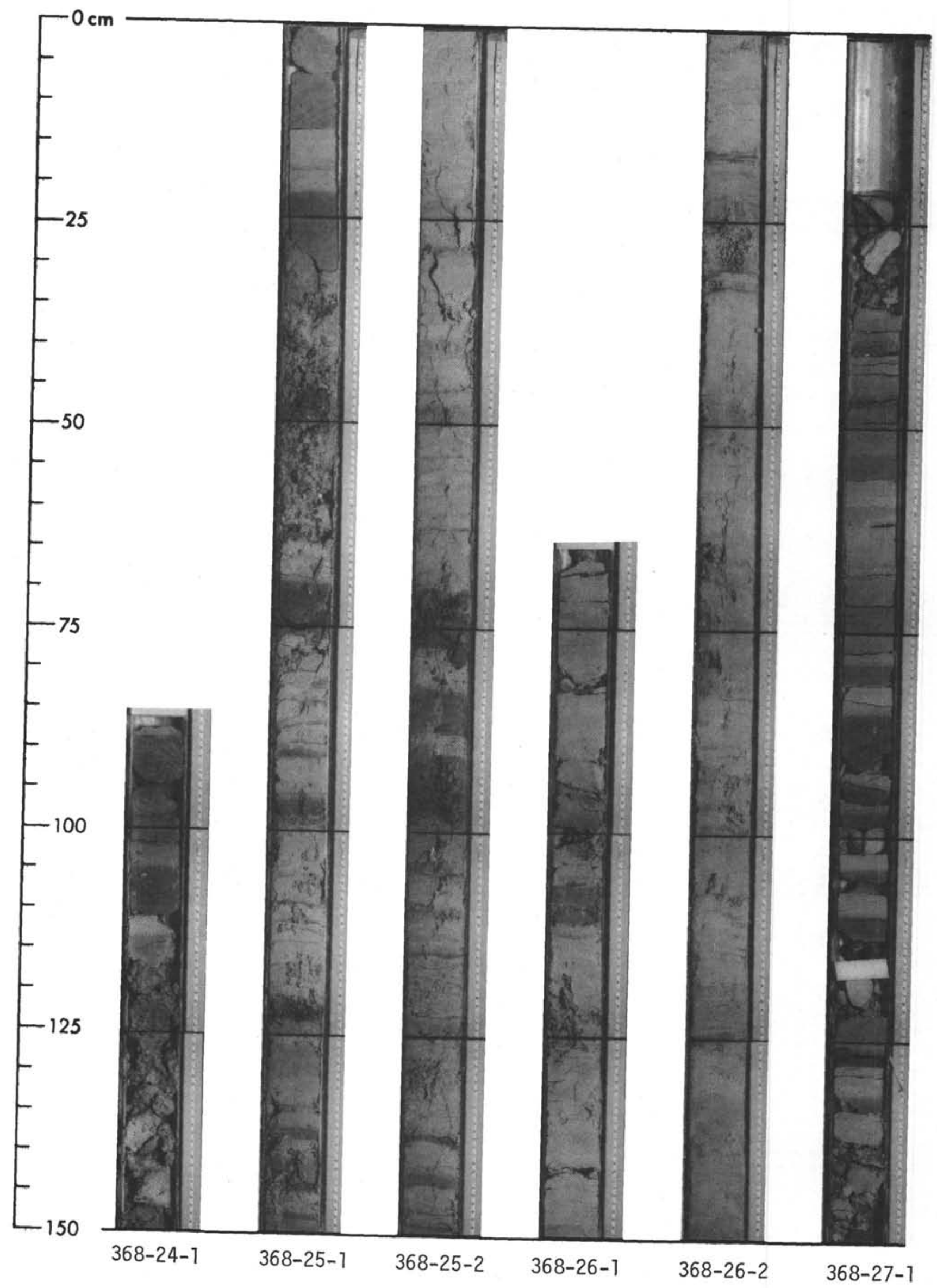




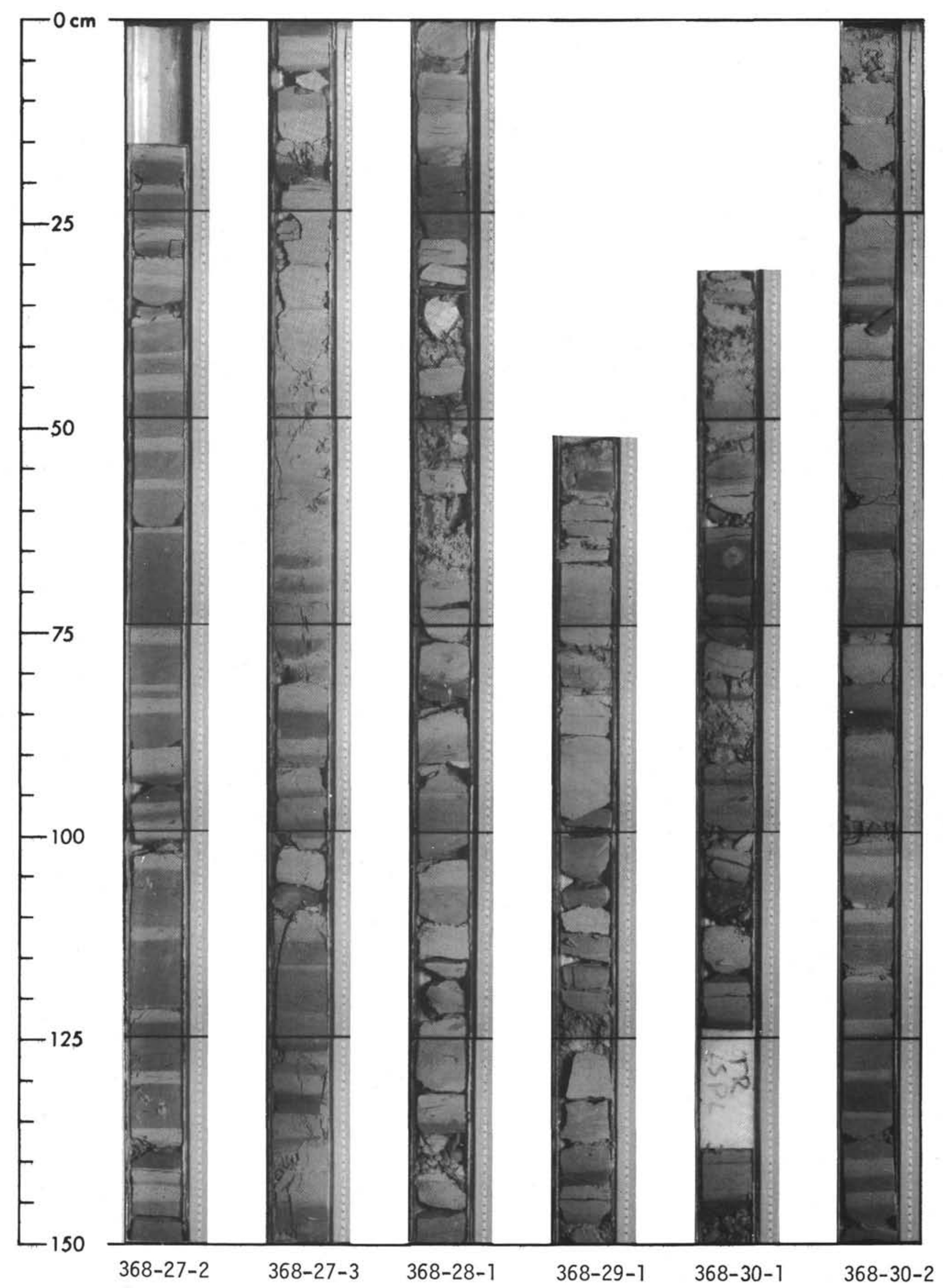




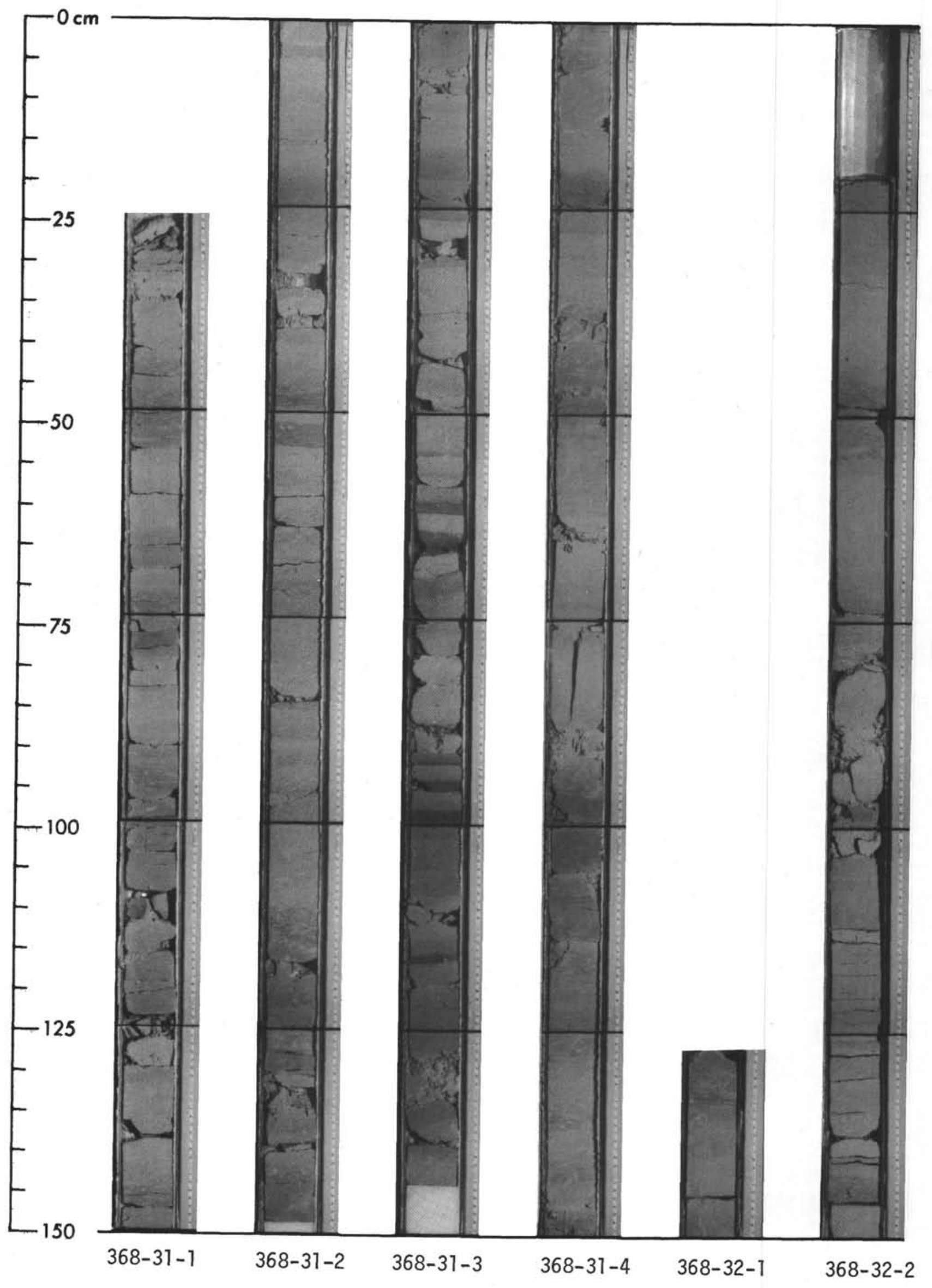




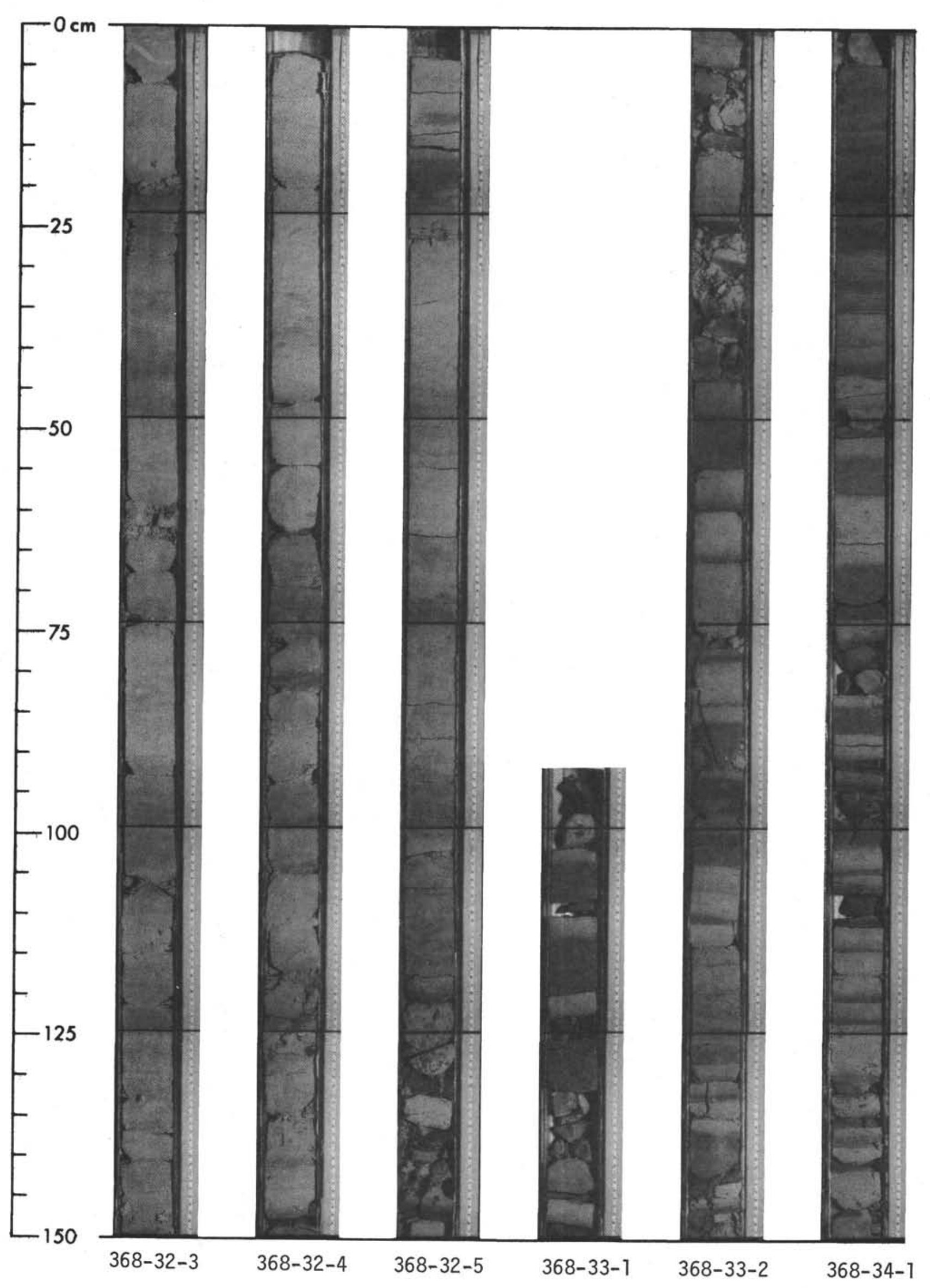




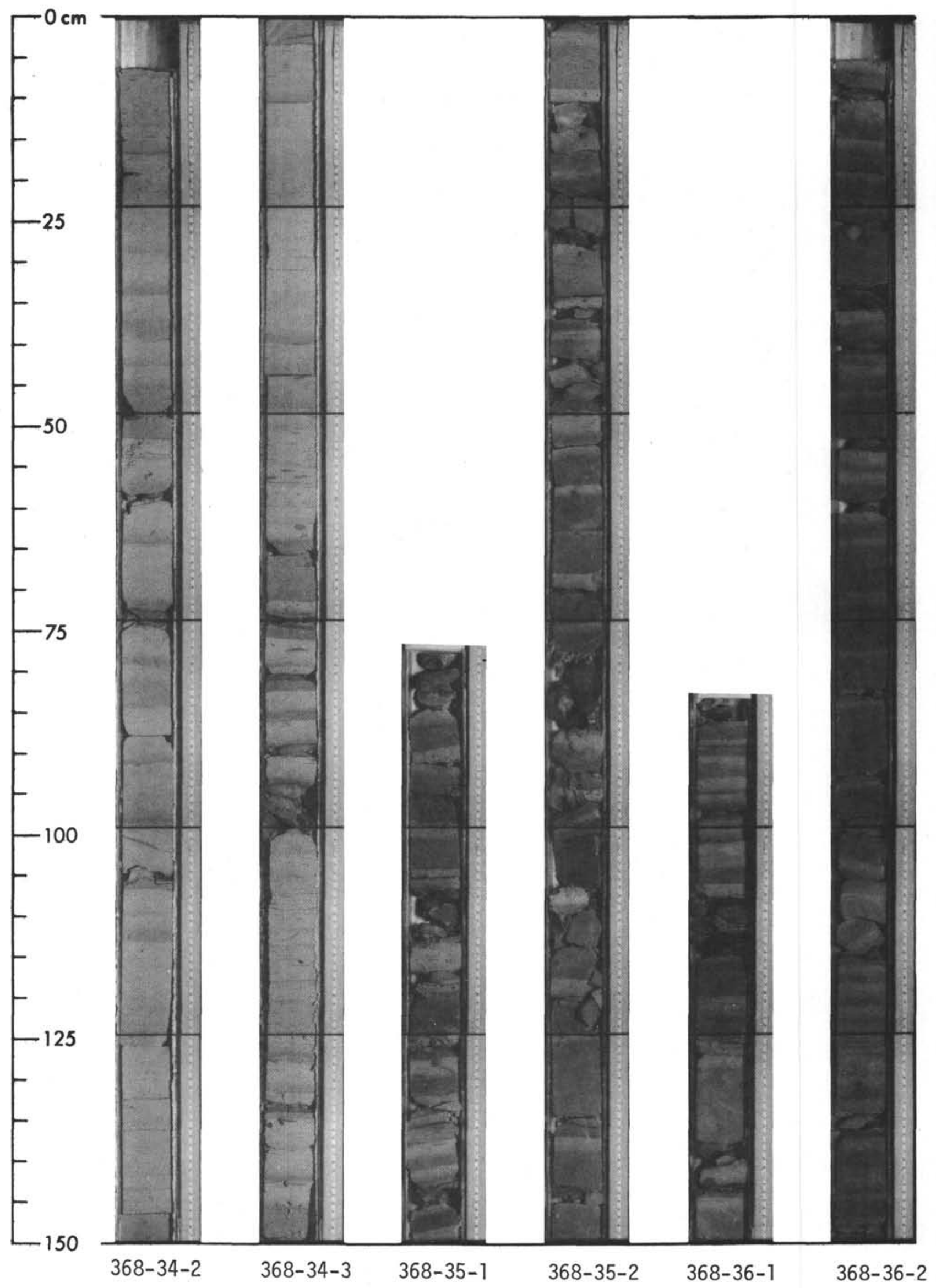




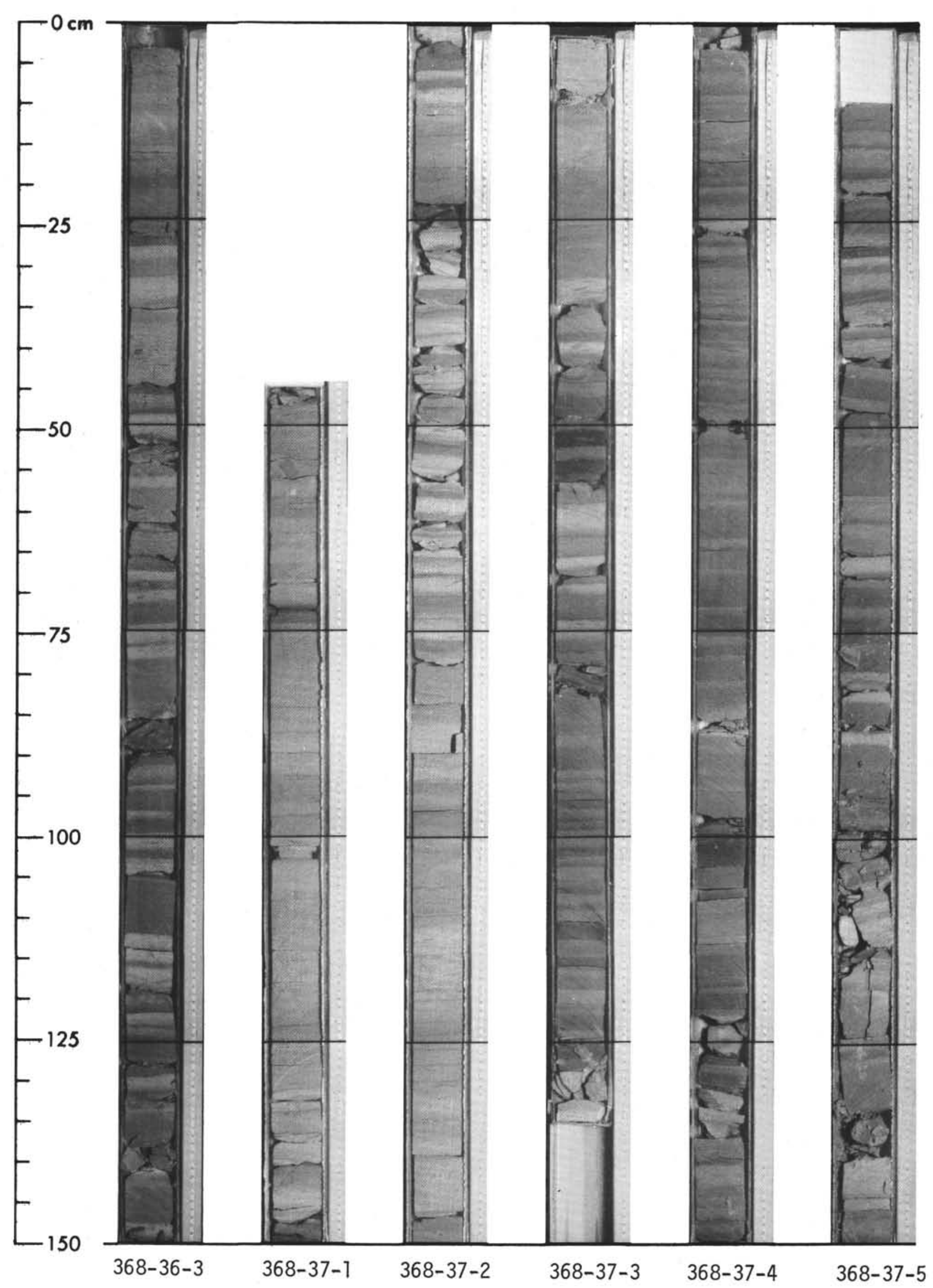




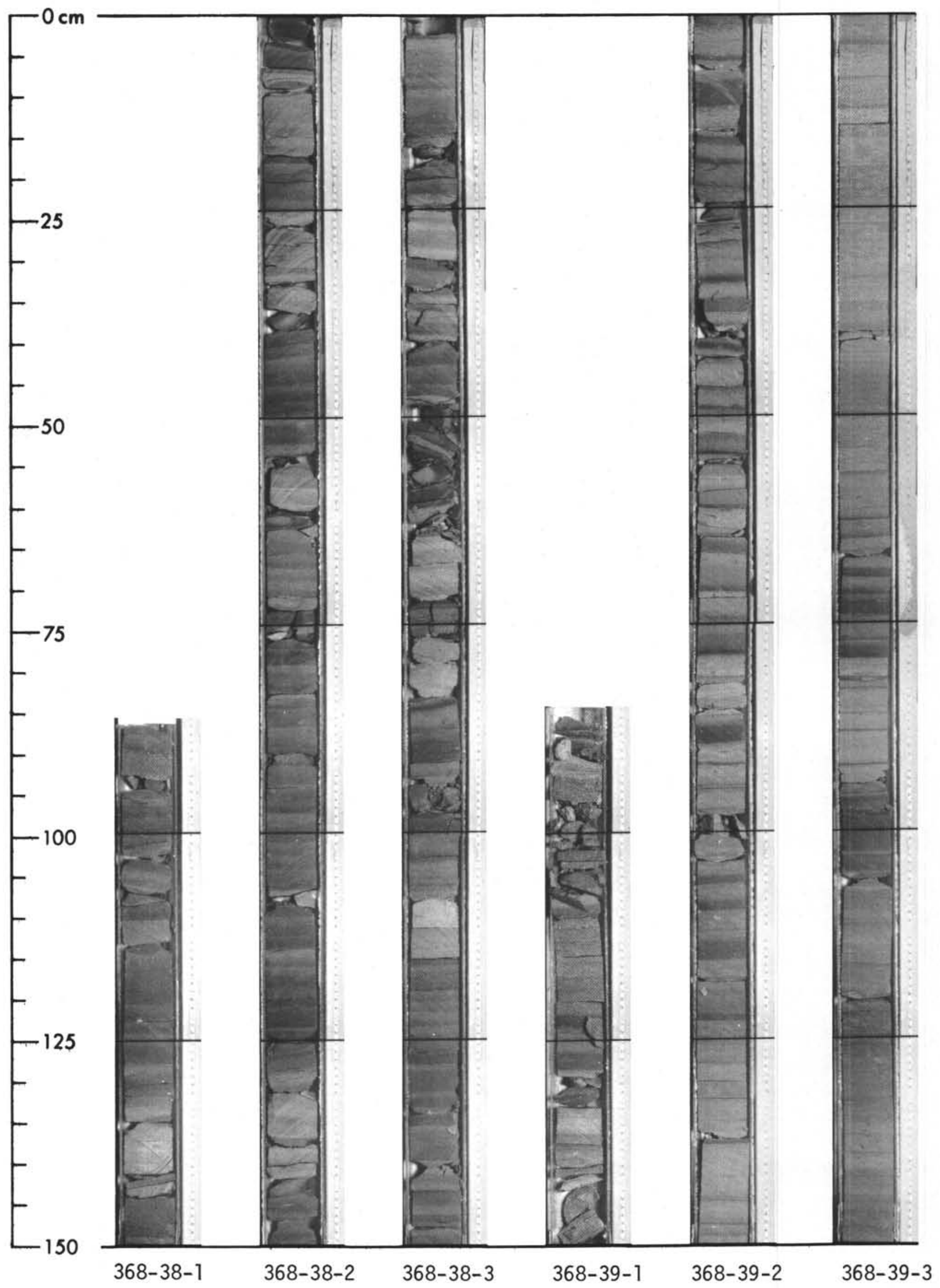




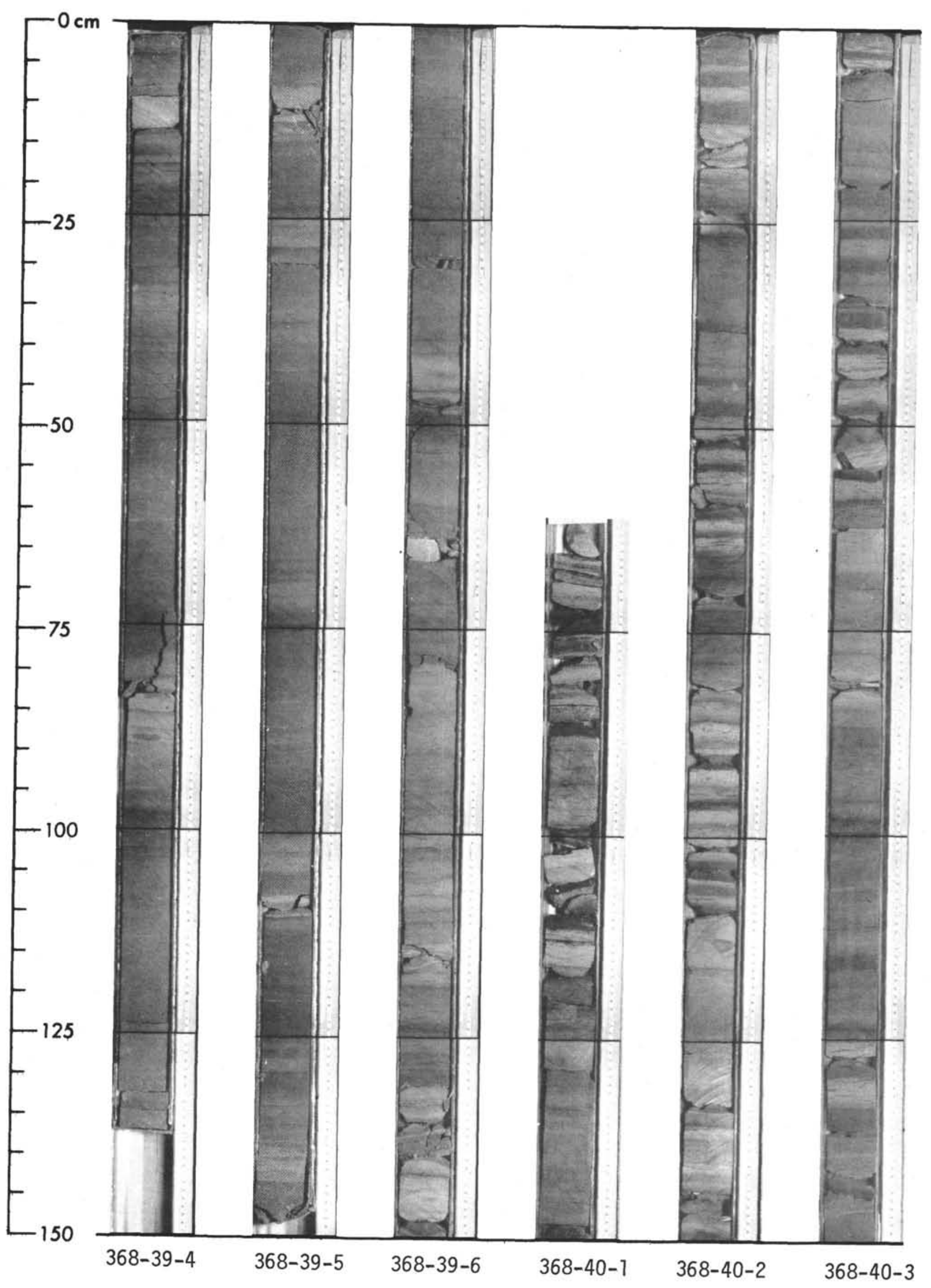




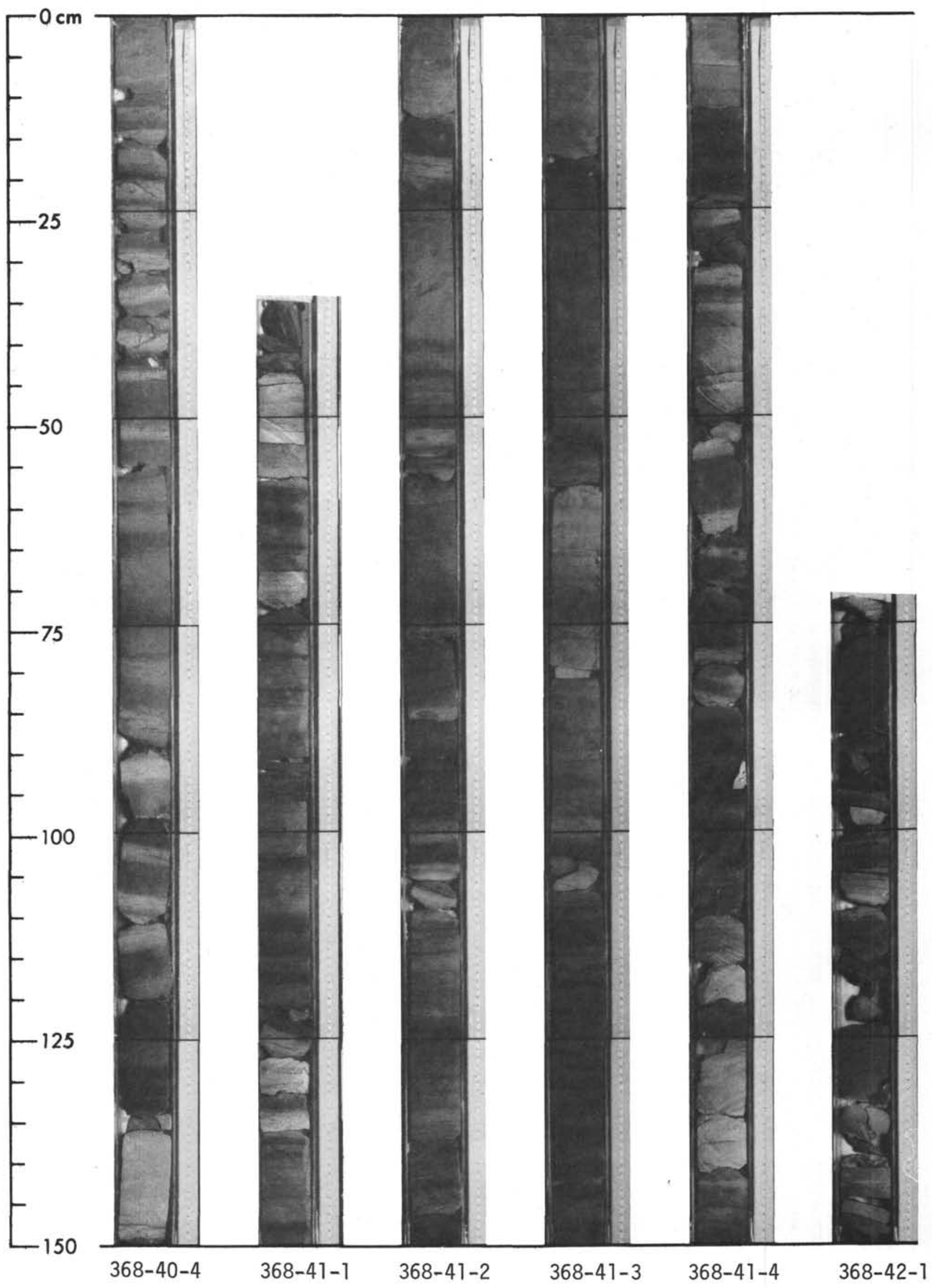




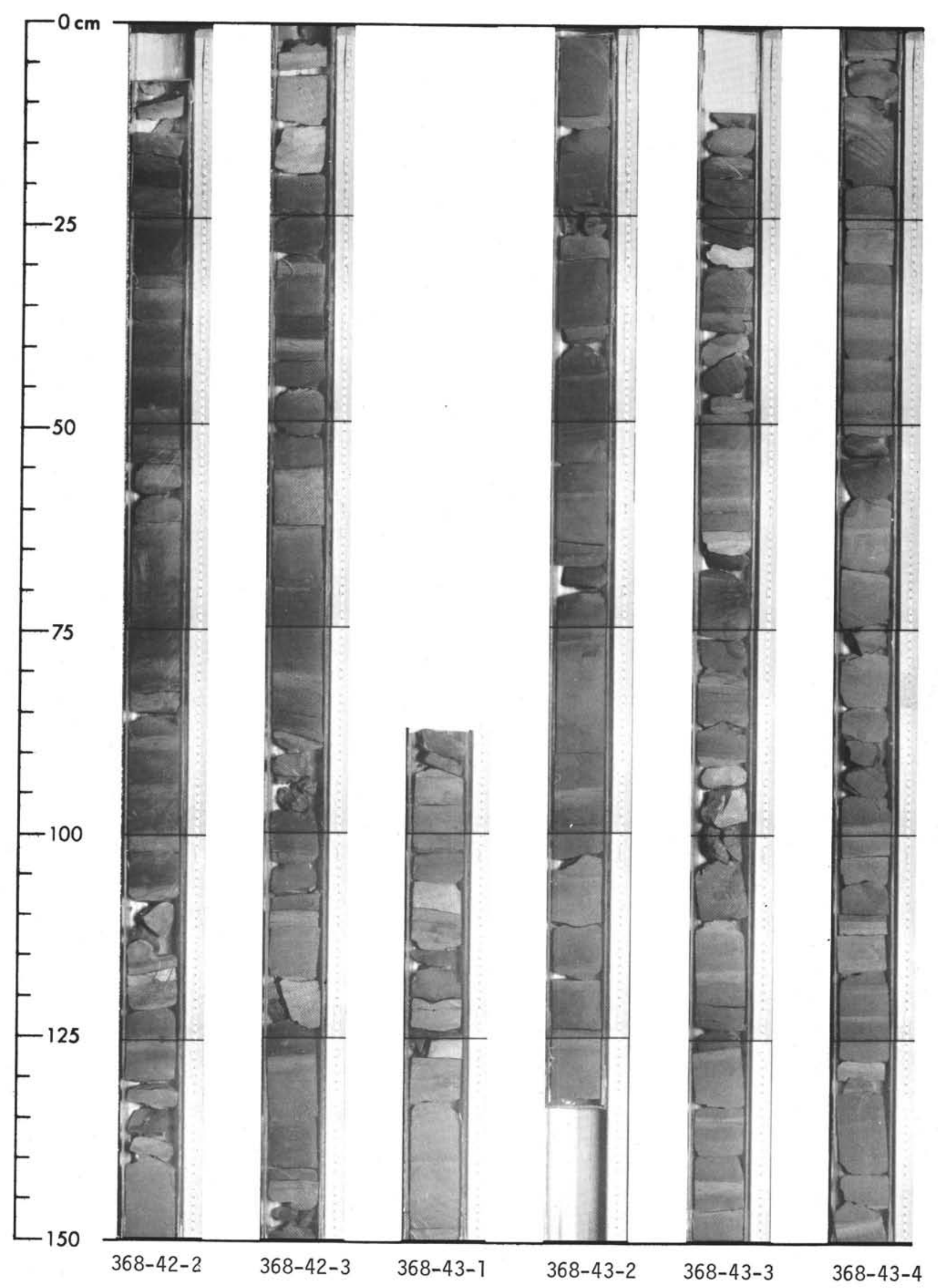




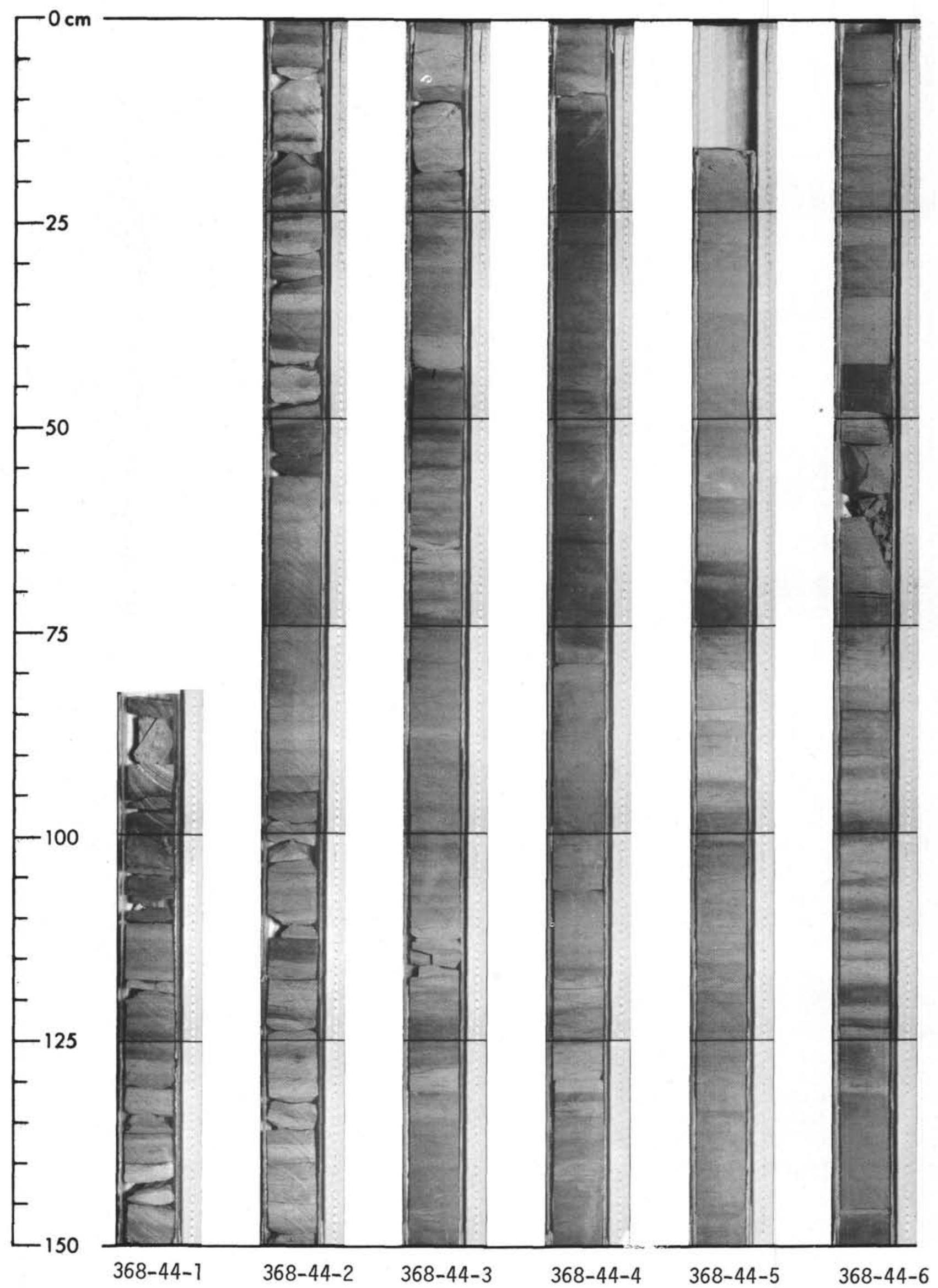




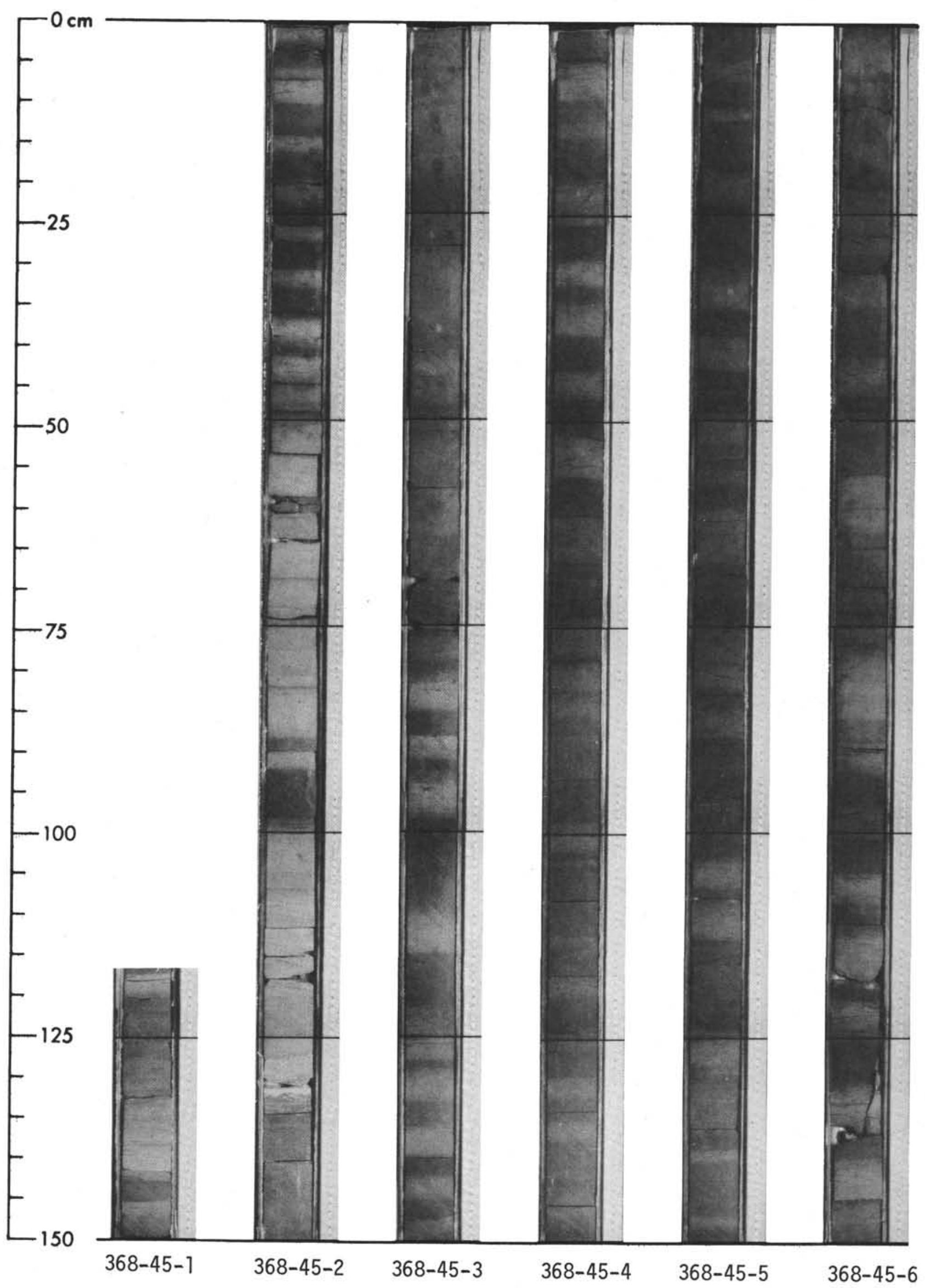




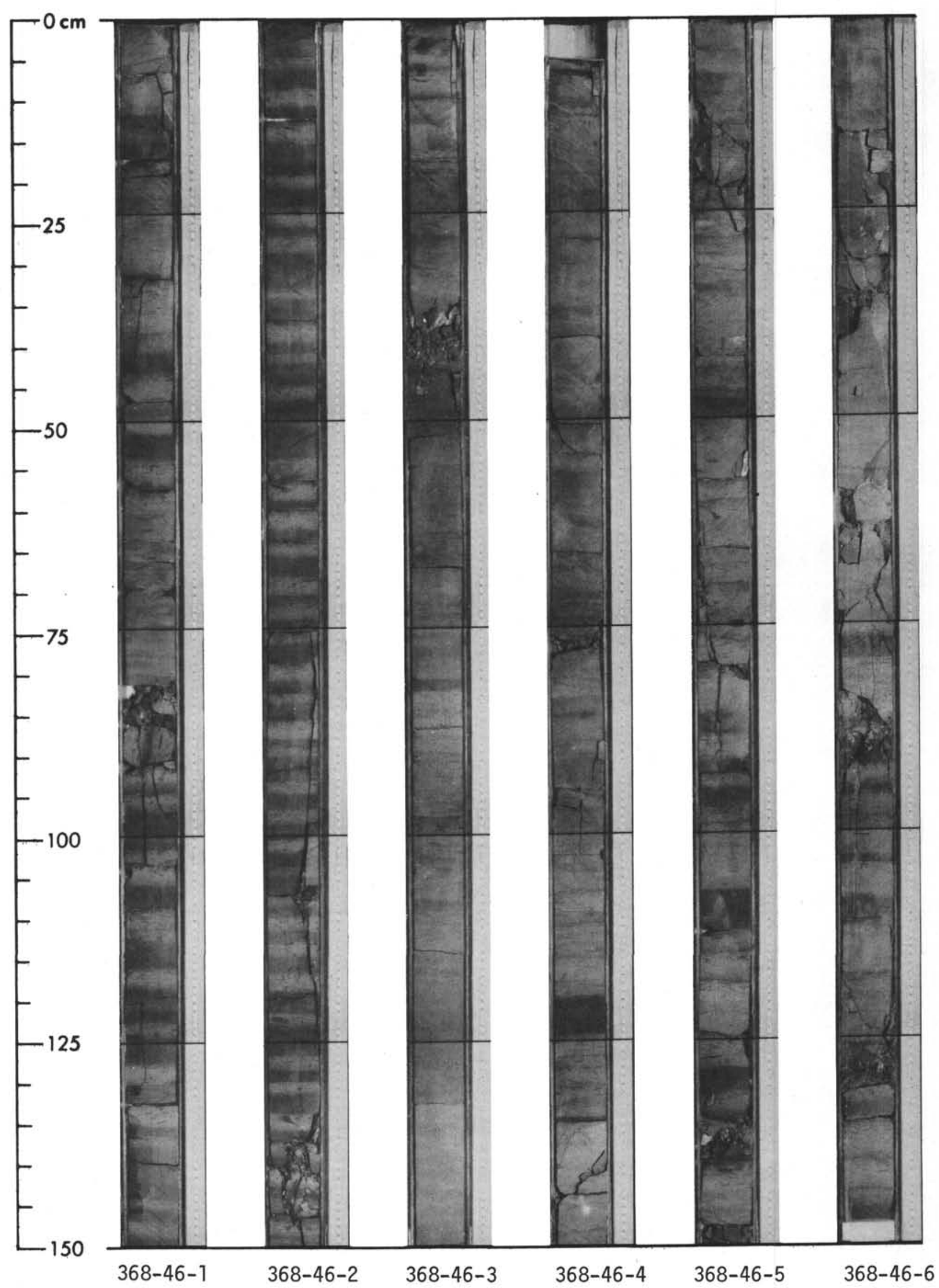




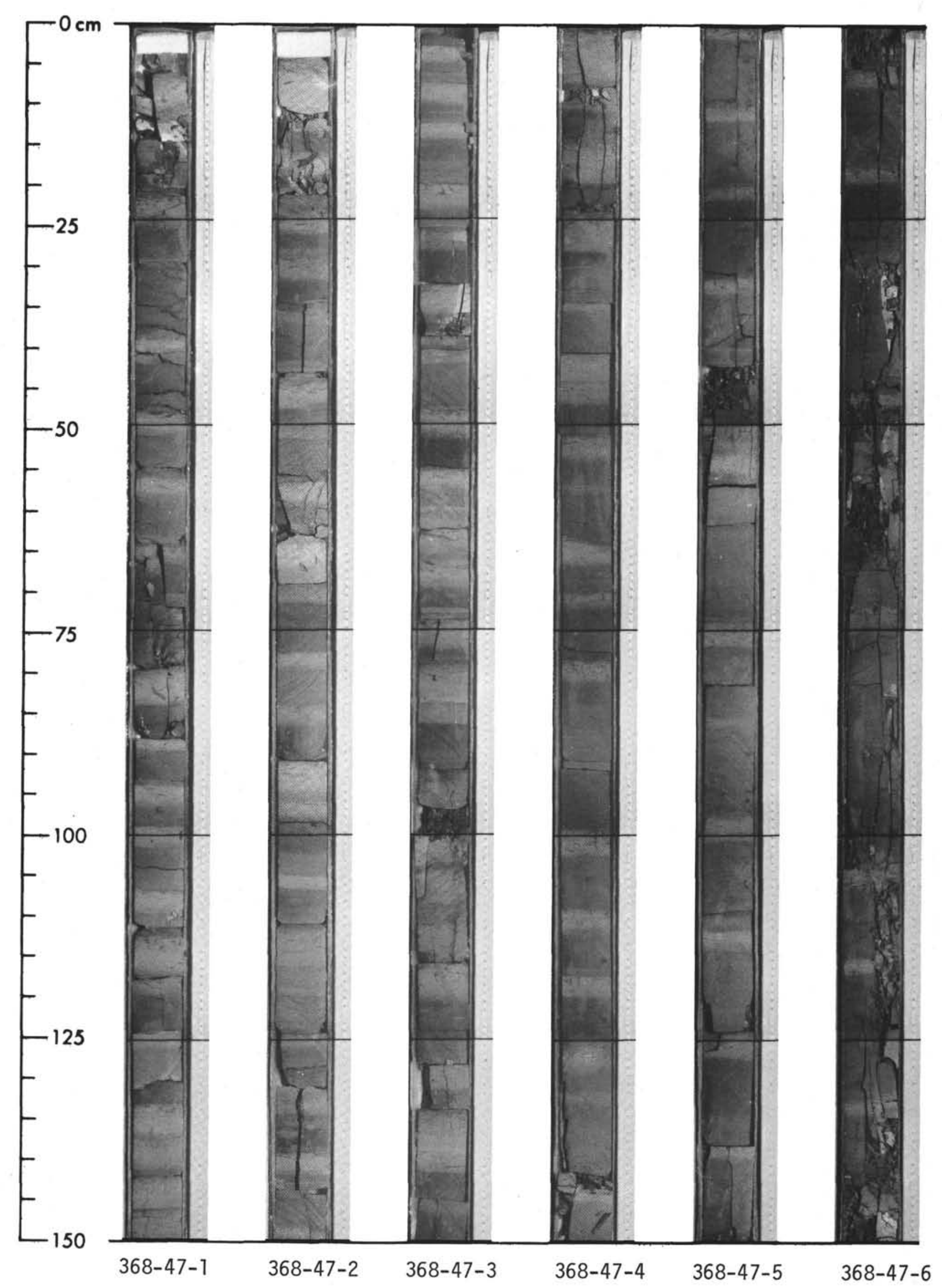




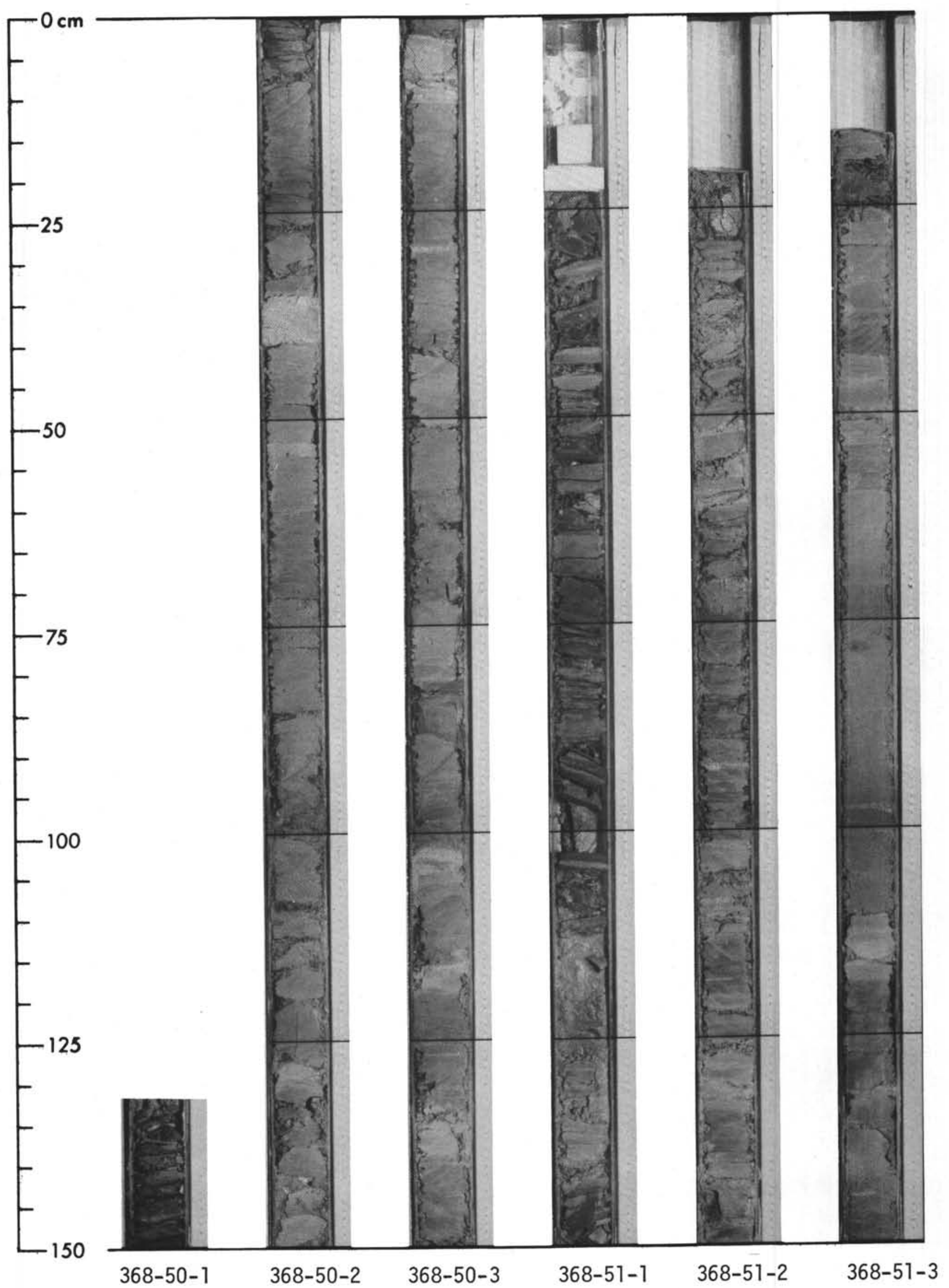




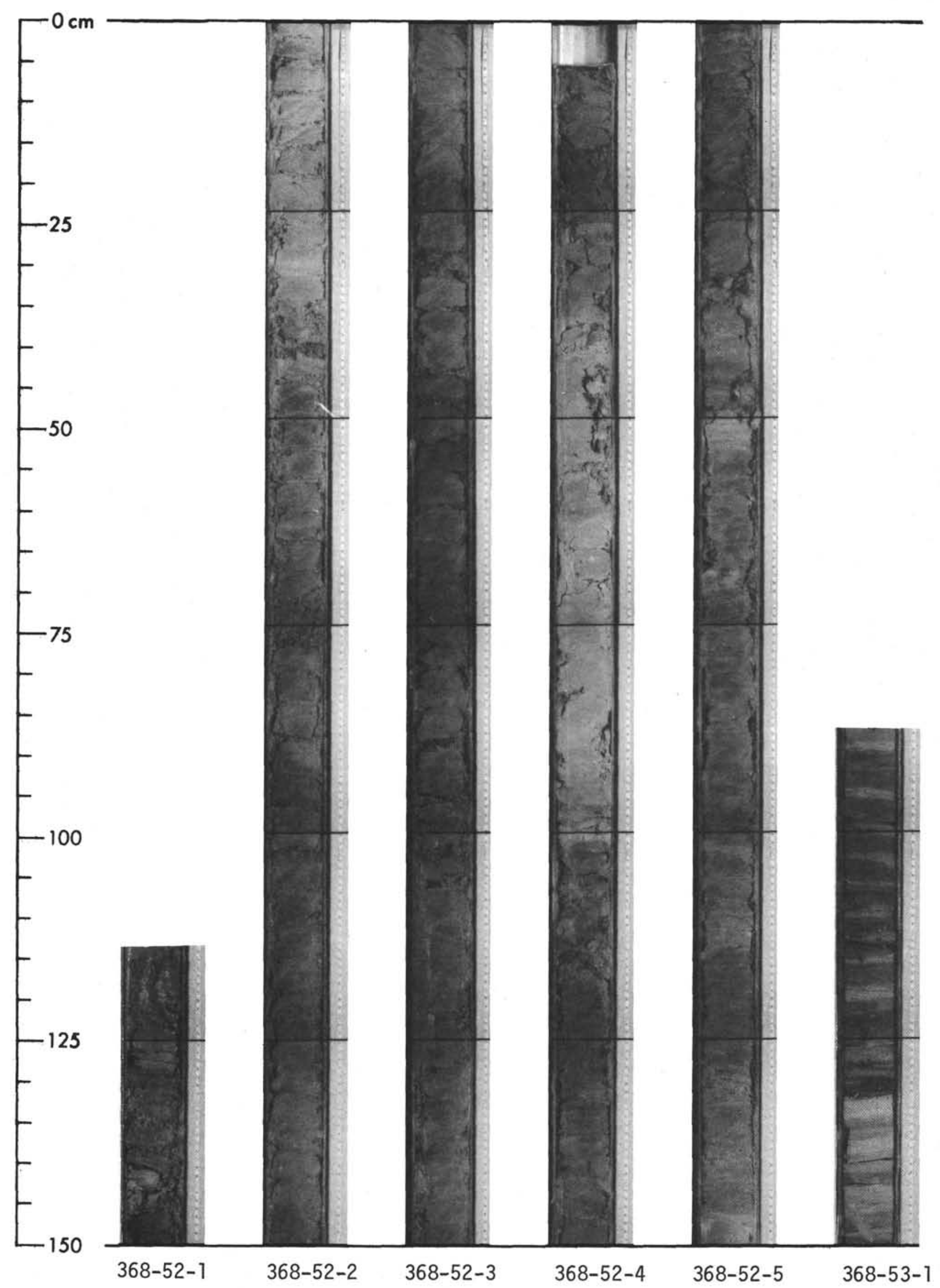




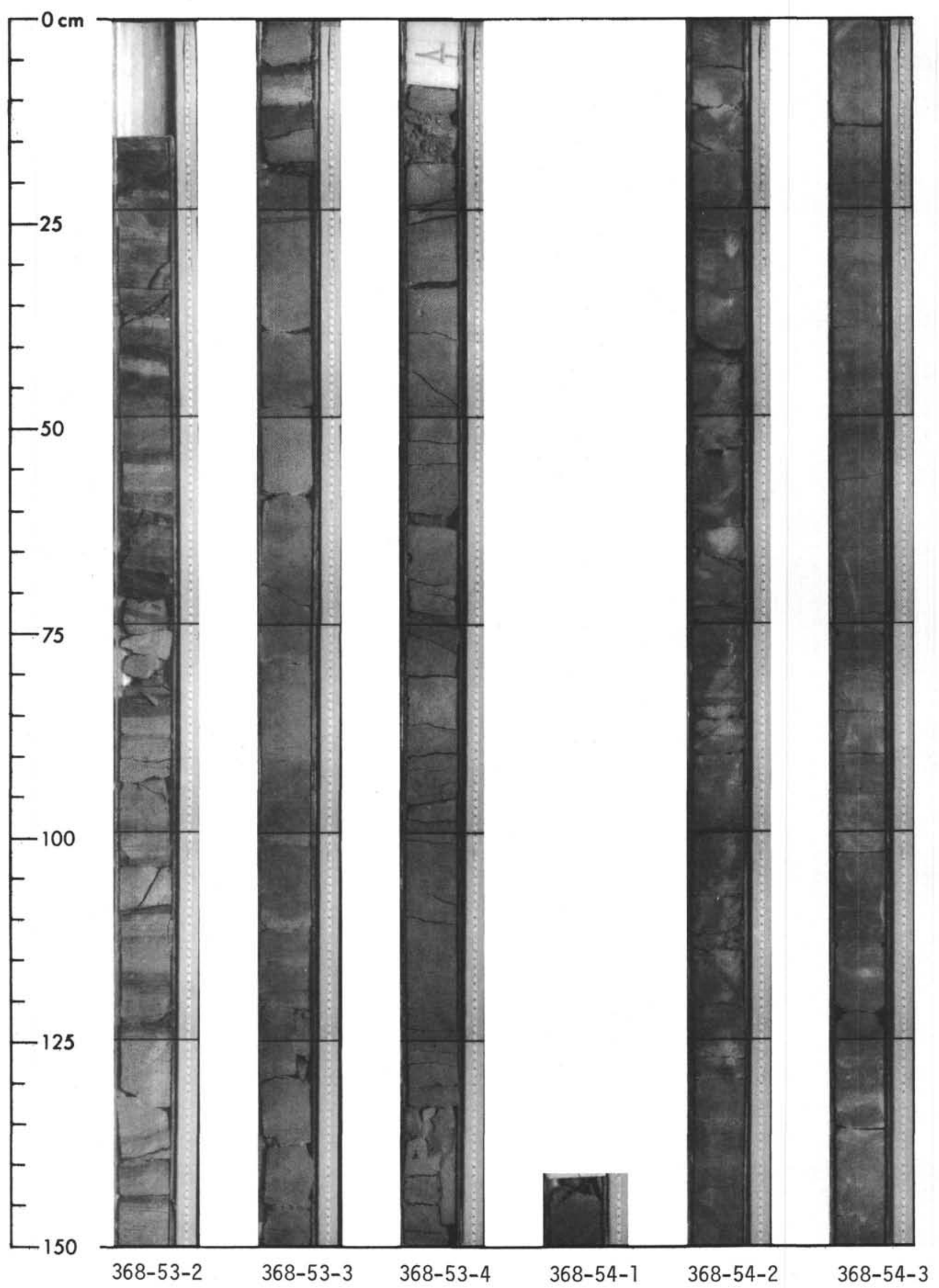




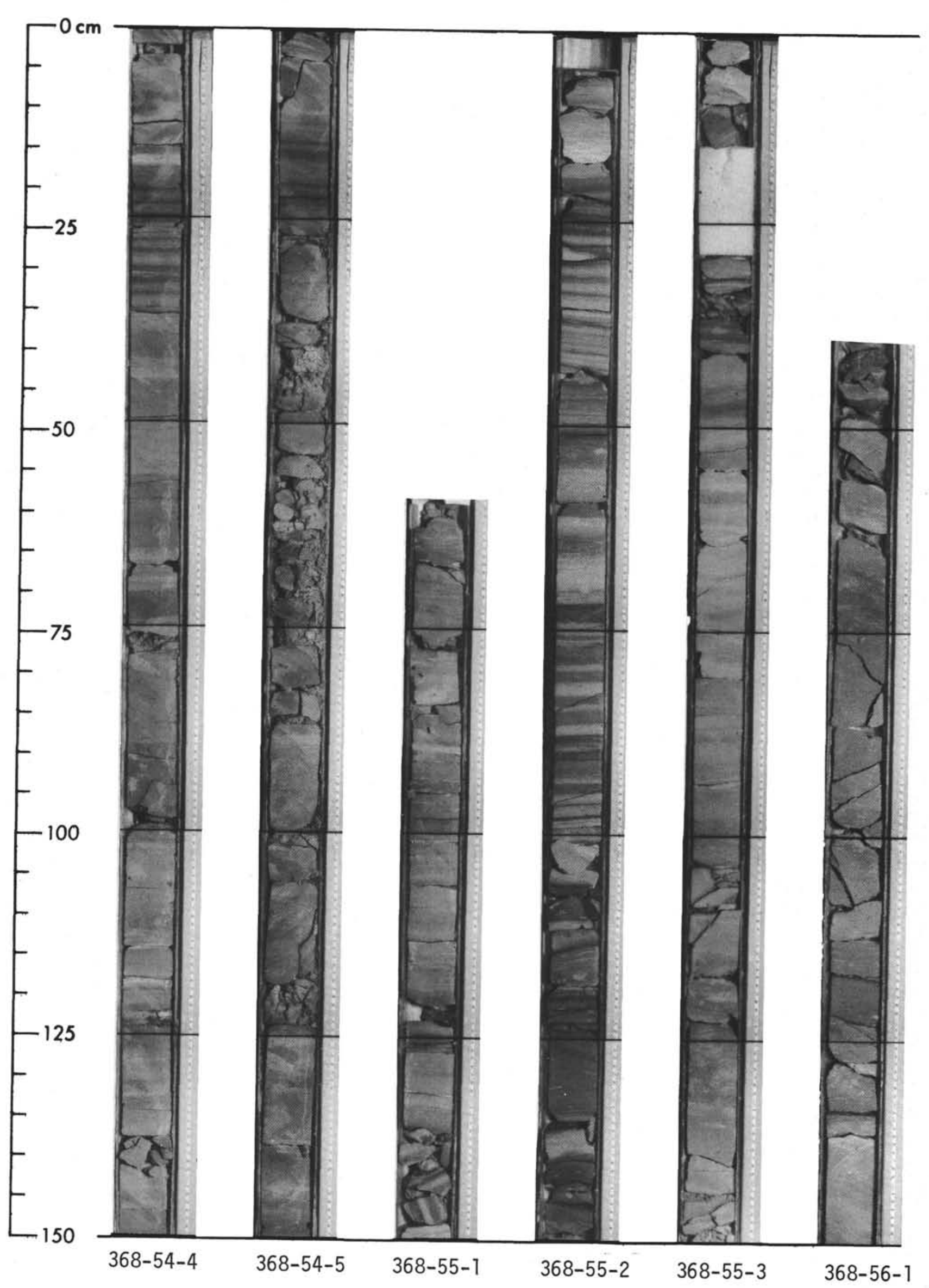




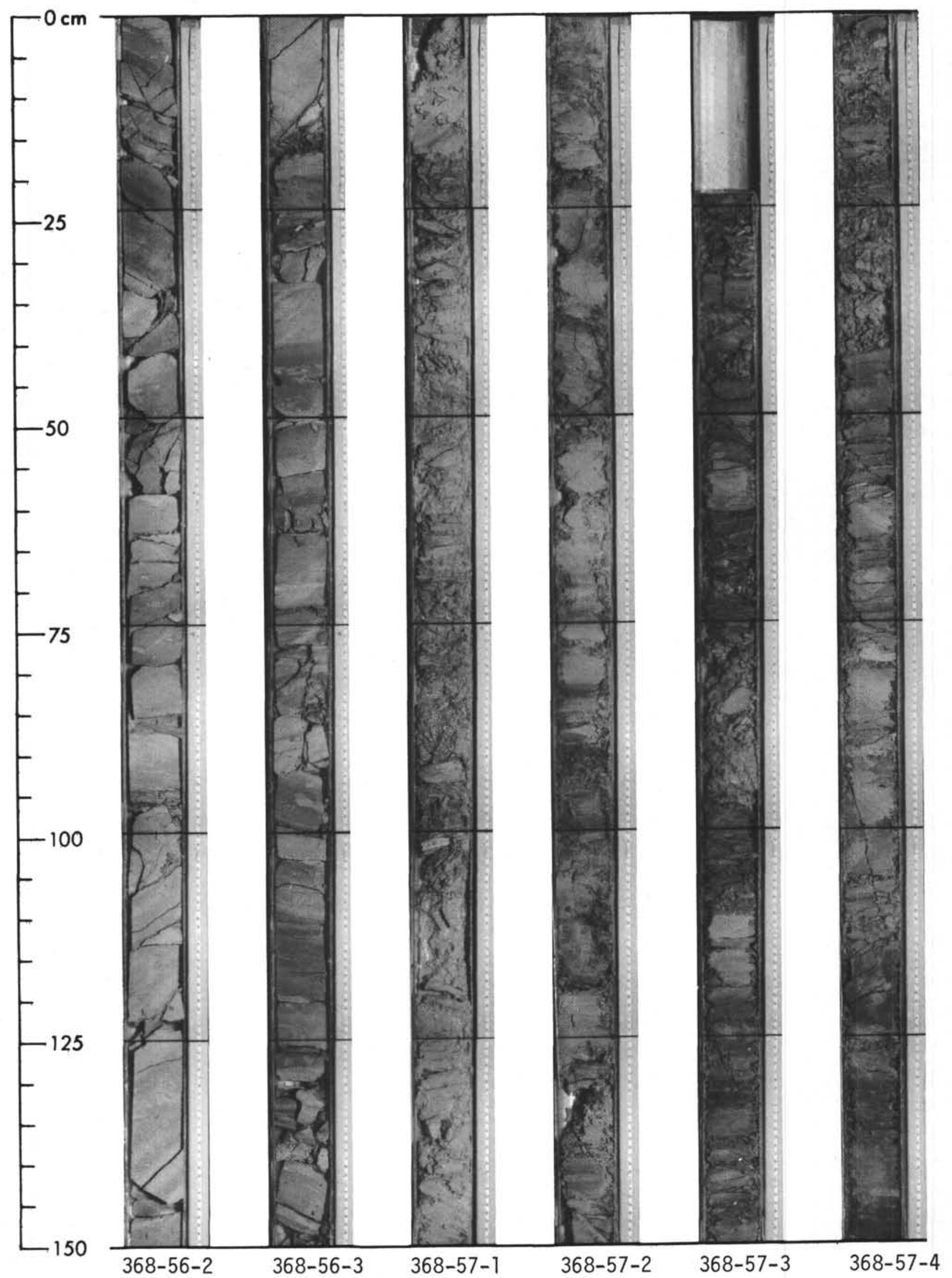




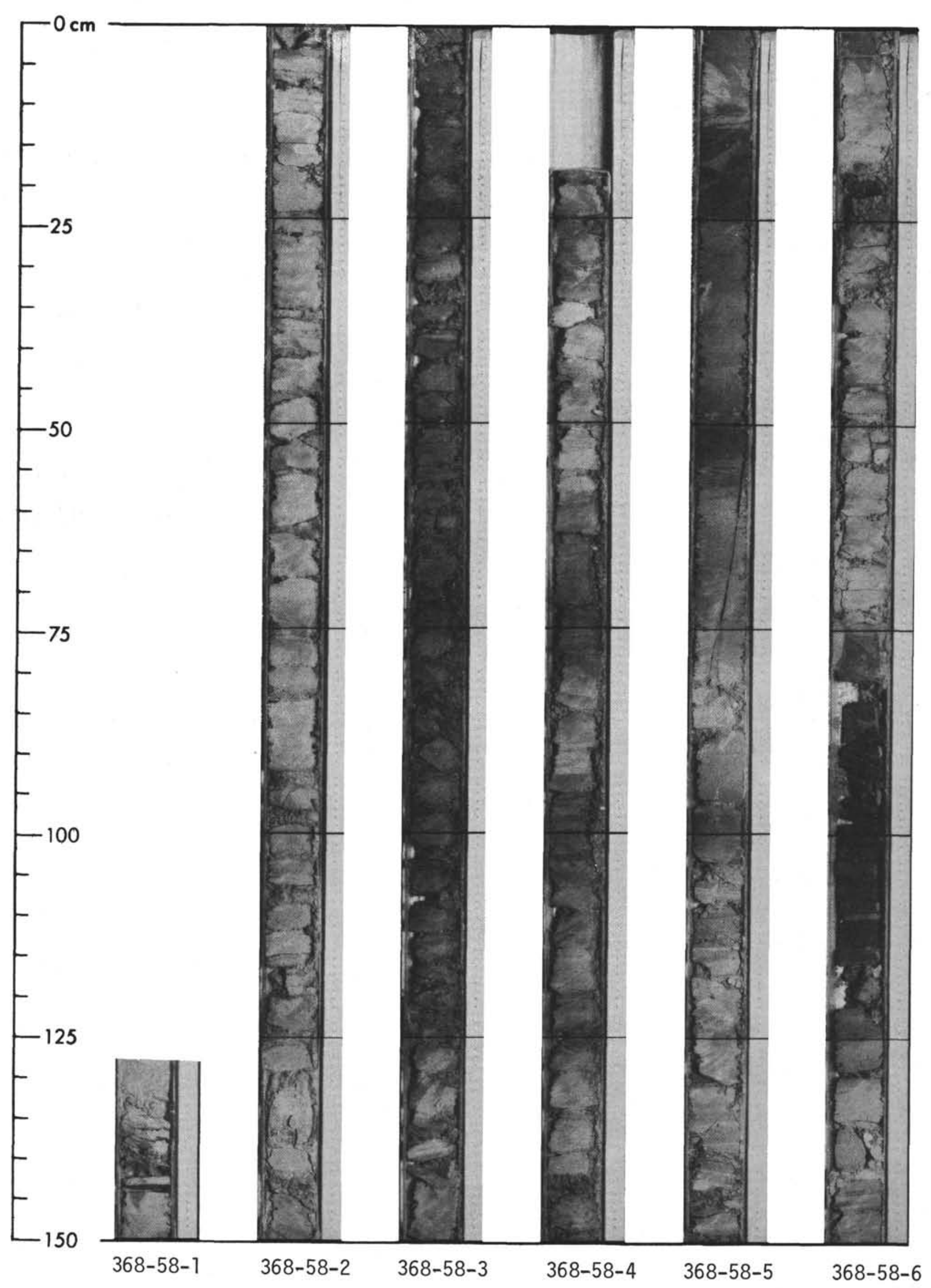




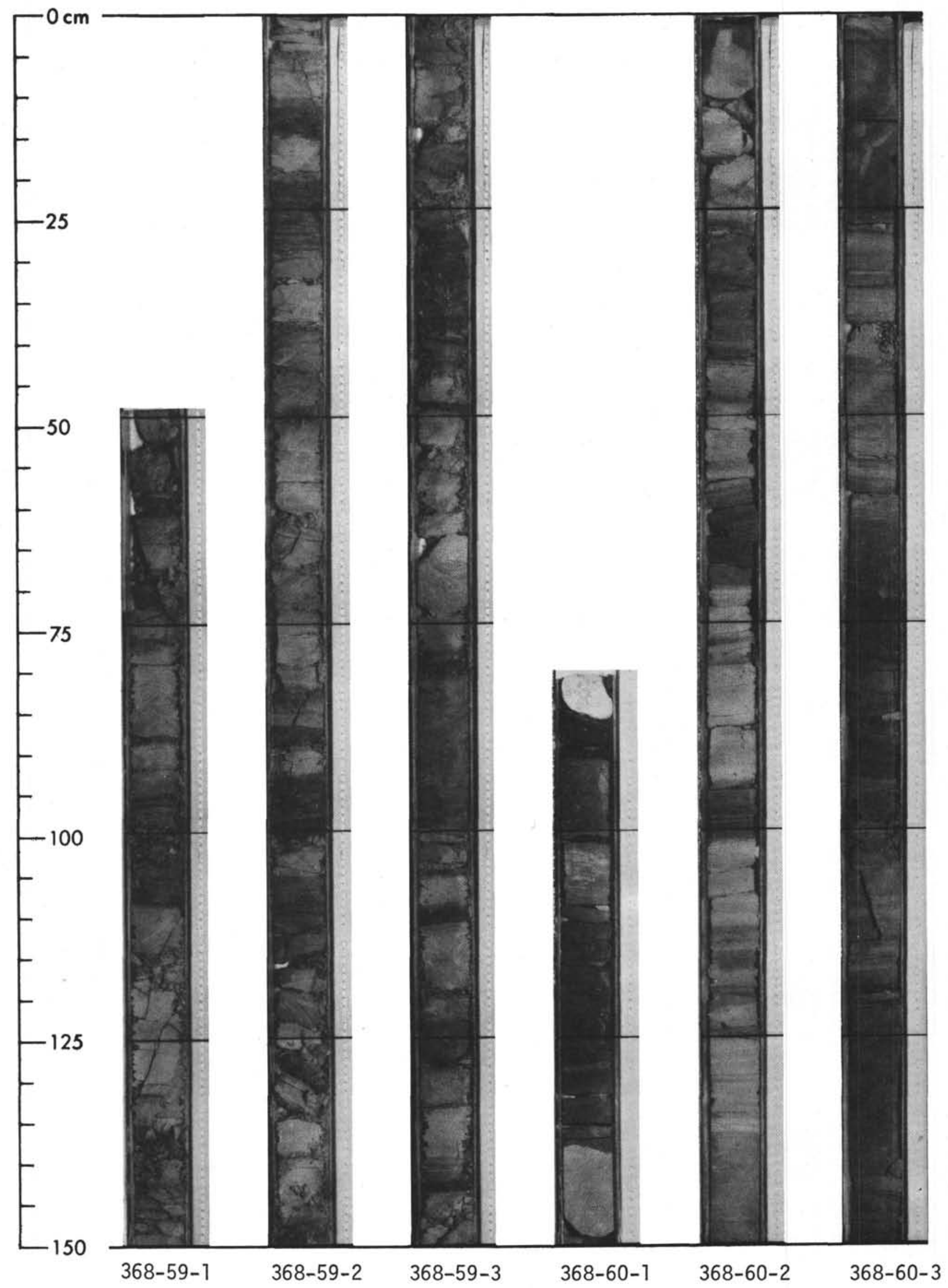




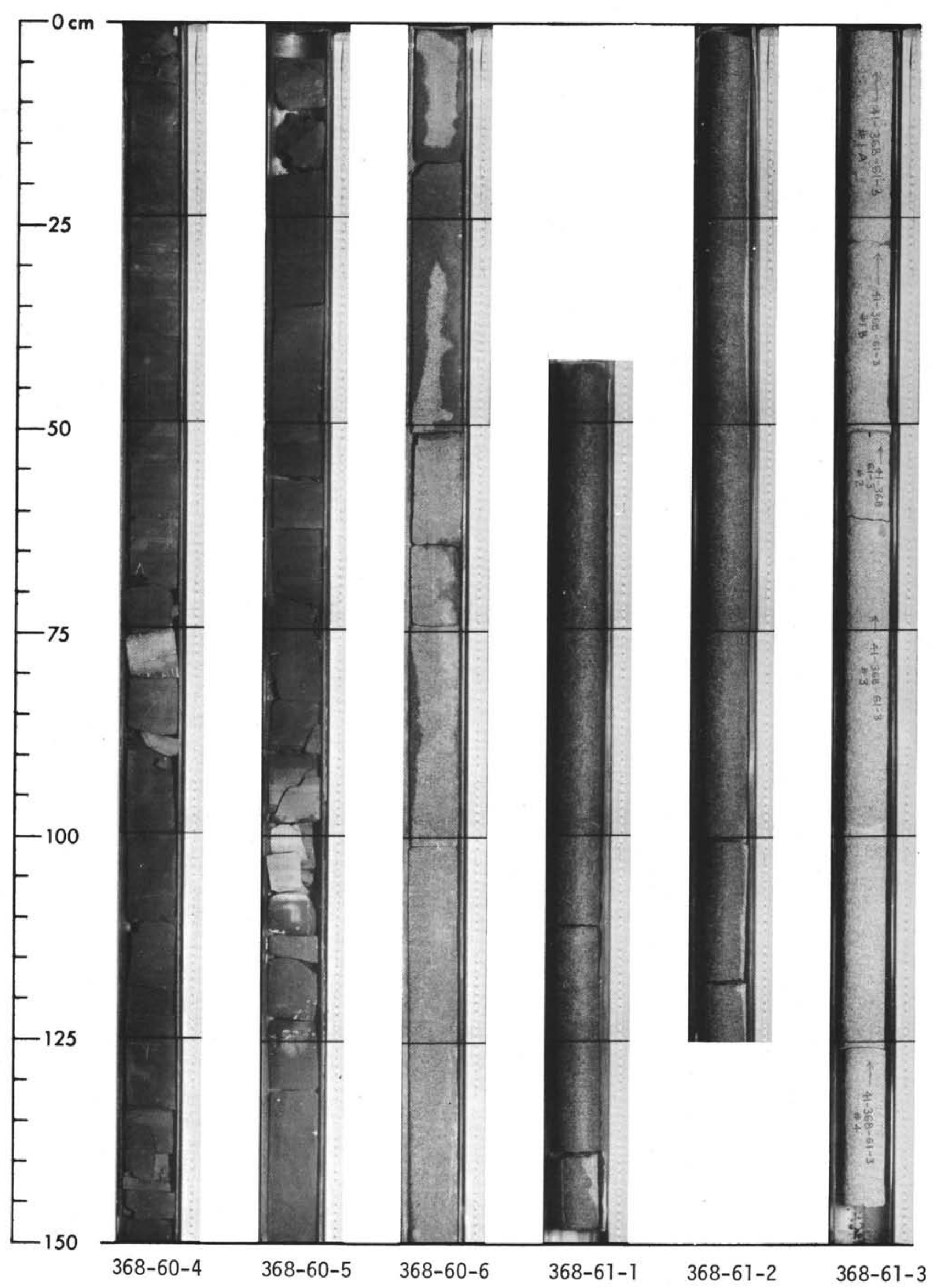


SITE 368: CAPE VERDE RISE

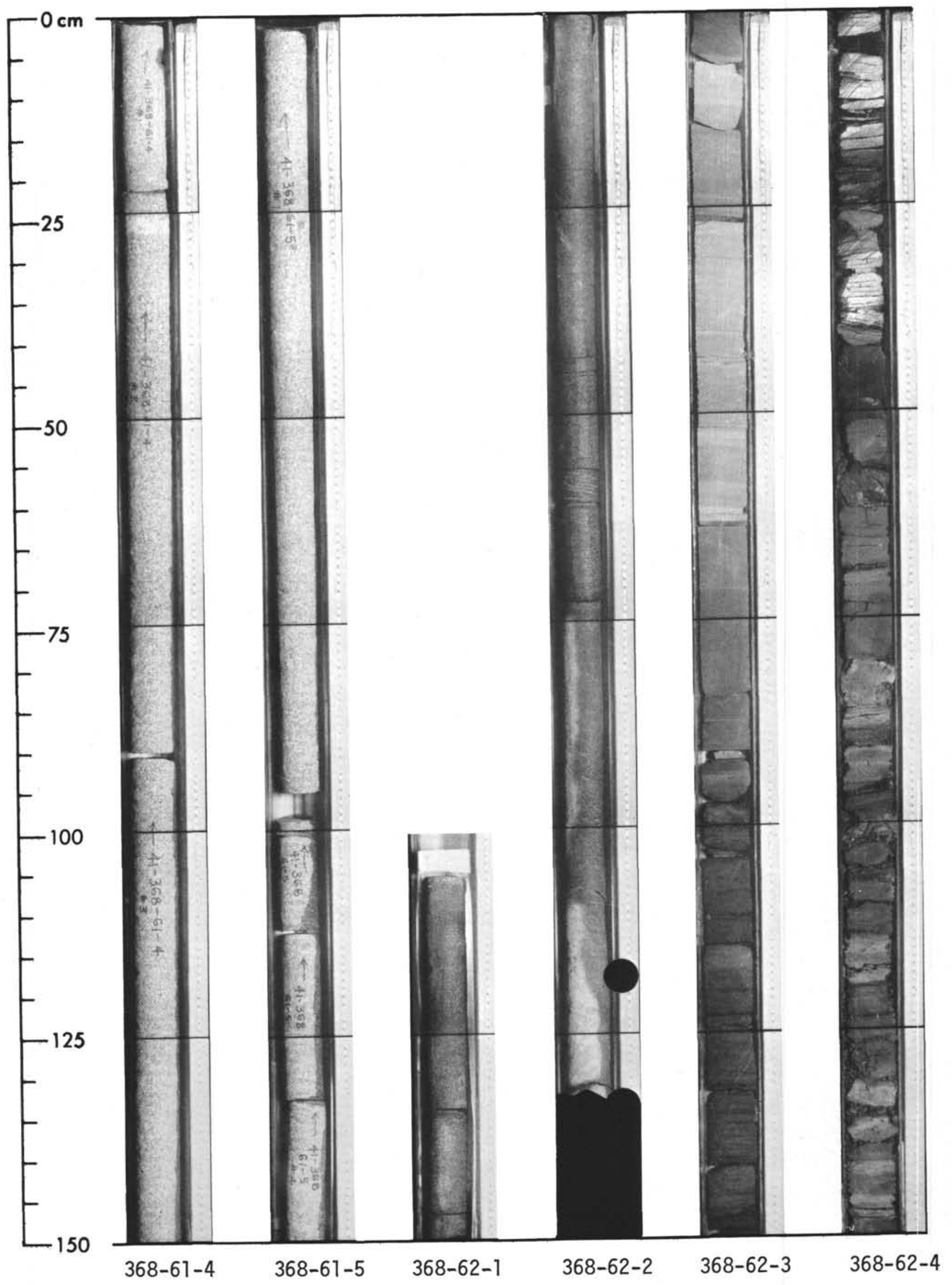




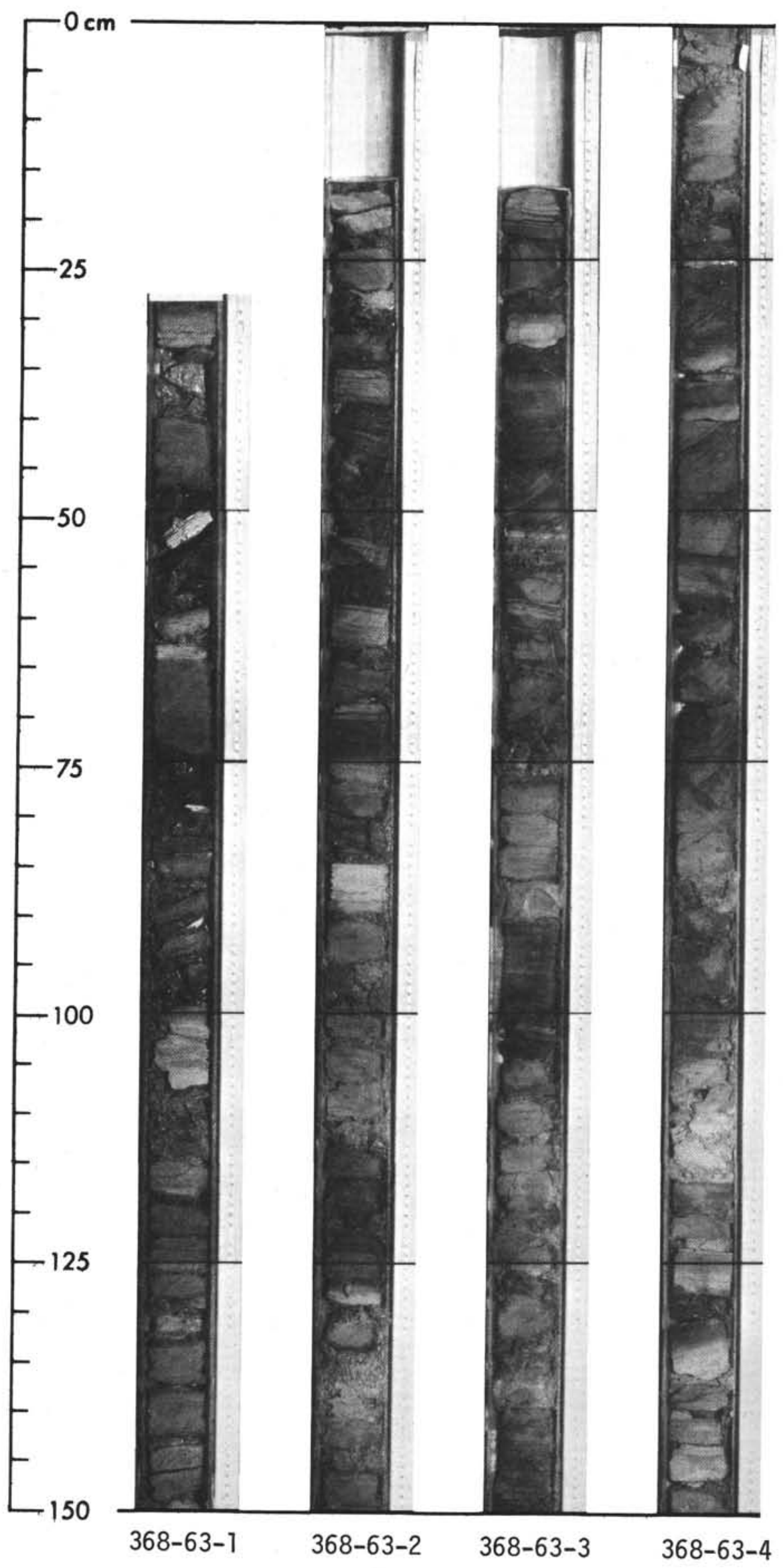

